\title{
Tracy Power Station -- Unit No. 4 Piñon Pine Power Project Public Design Report
}

\section{Topical Report}

\author{
DISCLAIMER
}

This report was prepared as an account of work sponsored by an agency of the United States Government. Neither the United States Government nor any agency thereof, nor any of their employees, makes any warranty, express or implied, or assumes any legal liability or responsibility for the accuracy, completeness, or usefulness of any information, apparatus, product, or process disclosed, or represents that its use would not infringe privately owned rights. Reference herein to any specific commercial product, process, or service by trade name, trademark, manufacturer, or otherwise does not necessarily constitute or imply its endorsement, recommendation, or favoring by the United States Government or any agency thereof. The views and opinions of authors expressed herein do not necessarily state or reflect those of the United States Government or any agency thereof.

\section{December 1994}

Work Performed Under Contract No.: DE-FC21-92MC29309

For

U.S. Department of Energy

Office of Fossil Energy

Morgantown Energy Technology Center

Morgantown, West Virginia

By

Sierra Pacific Power Company

Reno, Nevada 


\section{DISCLAIMER}

This report was prepared as an account of work sponsored by an agency of the United States Government. Neither the United States Government nor any agency thereof, nor any of their employees, makes any warranty, express or implied, or assumes any legal liability or responsibility for the accuracy, completeness, or usefulness of any information, apparatus, product, or process disclosed, or represents that its use would not infringe privately owned rights. Reference herein to any specific commercial product, process, or service by trade name, trademark, manufacturer, or otherwise does not necessarily constitute or imply its endorsement, recommendation, or favoring by the United States Government or any agency thereof. The views and opinions of authors expressed herein do not necessarily state or reflect those of the United States Government or any agency thereof.

This report has been reproduced directly from the best available copy.

Available to DOE and DOE contractors from the Office of Scientific and Technical Information, 175 Oak Ridge Turnpike, Oak Ridge, TN 37831; prices available at (615) 576-8401.

Available to the public from the National Technical Information Service, U.S. Department of Commerce, 5285 Port Royal Road, Springfield, VA 22161; phone orders accepted at (703) 487-4650. 
㟔

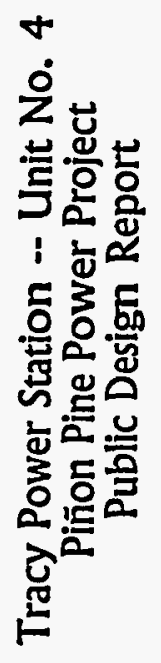

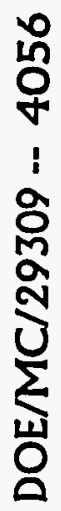


DOE/MC/29309 -- 4056 ।

\title{
Tracy Power Station -- Unit No. 4 Piñon Pine Power Project -- Public Design Report
}

\author{
Topical Report
}

Work Performed Under Contract No.: DE-FC21-92MC29309

\author{
For \\ U.S. Department of Energy \\ Office of Fossil Energy \\ Morgantown Energy Technology Center \\ P.O. Box 880 \\ Morgantown, West Virginia 26507-0880 \\ By \\ Sierra Pacific Power Company \\ P.O. Box 10100 \\ 6100 Neil Road \\ Reno, Nevada 89520-0400
}




\section{GLOSSARY}

ACFM Actual Cubic Feet per Minute

BFW Boiler Feed Water

Btu British thermal unit

$\mathrm{CaCO}_{3} \quad$ Calcium Carbonate

$\mathrm{CaO} \quad$ Calcium Oxide

$\mathrm{CaS} \quad$ Calcium Sulfide

$\mathrm{CaSO}_{4} \quad$ Calcium Sulfate

CEMS Continuous Emissions Monitoring System

CFM Cubic Feet per Minute

COS Carbonyl Sulfide

DAS Data Acquisition System

DC Direct Current

DCS Digital Control System

DHEW Department of Health, Education and Welfare

DOE U.S. Department of Energy

EHSS Environmental, Health, Safety and Socioeconomic

EIS Environmental Impact Statement

FW USA Foster Wheeler USA Corporation

GPM Gallons Per Minute

$\mathrm{H}_{2} \mathrm{O} \quad$ Water

$\mathrm{H}_{2} \mathrm{~S}$ 'Hydrogen Sulfide

$\mathrm{Hg} \quad$ Mercury

HgA Mercury Absolute

HHV High Heating Value

HRSG Heat Recovery Steam Generator

HVAC Heating, Ventilation, Air Conditioning

I/O Input/Output

IGCC Integrated Gasification Combined-Cycle

ISO International Standards Organization

KRW Kellogg-Rust-Westinghouse

$\mathrm{kW} \quad$ Kilowatt

kWh Kilowatt hour

LASH Coal ash with spent limestone

LHV Low Heating Value

MCE Maximum Credible Earthquake

MW Megawatt (1 million watts) or Molecular Weight

MWe Million Watts

MWK M. W. Kellogg Company

NFPA National Fire Prevention Association

NiO Nickel Oxide

NIOSH National Institute of Occupational Safety and Health 


$\begin{array}{ll}\text { NiS } & \text { Nickel Sulfide } \\ \mathrm{NO}_{\mathrm{x}} & \text { Nitrogen Oxides } \\ \text { O } & \text { Oxygen } \\ \text { OSHA } & \text { Occupational Health and Safety Act } \\ \text { P.I.V.'s } & \text { Post indicator valves } \\ \text { PDU } & \text { Process development unit } \\ \text { pf } & \text { Power factor } \\ \text { PON } & \text { Program Opportunity Notice } \\ \text { ppmv } & \text { Parts per million by volume } \\ \text { psia } & \text { Pounds per square inch, absolute } \\ \text { RH } & \text { Relative Humidity } \\ \text { RIE } & \text { Remote Instrument Enclosure } \\ \text { RPM } & \text { Revolutions Per Minute } \\ \text { SCFM } & \text { Standard Cubic Feet per Minute } \\ \text { SO } & \text { Sulfur Dioxide } \\ \text { SO } & \text { Sulfur Oxides } \\ \text { SPPCo } & \text { Sierra Pacific Power Company } \\ \text { SUFCO } & \text { Southern Utah Fuel Company } \\ \text { TPD } & \text { Tons Per Day } \\ \text { TPH } & \text { Tons Per Hour } \\ \text { U/G } & \text { Underground } \\ \text { UPS } & \text { Uninterruptible Power Source } \\ \text { ZnO } & \text { Zinc Oxide } \\ \text { ZnS } & \text { Zinc Sulfide }\end{array}$


TABLE OF CONTENTS

1.0 INTRODUCTION

2.0 PROGRAM BACKGROUND

3.0 TECHNOLOGY OVERVIEW

4.0 DESIGN CONSIDERATIONS

4.1 Location and Description of Site

4.2 Area Geology

4.3 Environmental, Safety and Hazard Considerations

4.4 Supplied Utilities

4.4.1 Coal Supply

4.4.2 Limestone

4.4.3 Natural Gas

4.4.4 Electric Power

4.4.5 Water Requirement and Availability ..

4.4.6 Transportation System

4.4.7 Solid Waste Handling

\subsection{PLANT DESCRIPTION}

5.1 Combined-Cycle

5.1.1 Gas Turbine Generator (Area 700)

5.1.2 Steam Turbine Generator and Heat Recovery Steam Generator (Area 800)

5.1.2.1 Heat Recovery Steam Generator

5.1.2.2 Stack

5.1.2.3 Steam Turbine Generator

$5.2 \quad$ Gasifier Island

5.2.1 Coal Gasification (Area 300)

5.2.2 Oxidant Compression and Supply (Area 200)

5.2.3 Gas Stream Heat Recovery (Area 400)

5.2.4 Gas Stream Particulate Removal (Area 500)

5.2.5 Desulfurization (Area 600)

5.2.6 Recycle Gas Compression (Area 900) 


\subsection{Offsites}

5.3.1 Solids Receiving and Grinding (Area 100)

5.3.1.1 Raw Coal Receiving and Storage

5.3.1.2 Coal Crushing and Screening

5.3.1.3 Coal, Coke and Limestone Feeding

5.3.1.4 Dust Collection System

5.3.2 Solid Waste Handling (Area 1100)

5.3.3 Balance of Plant (Area 1200)

5.3.3.1 Raw Water System

5.3.3.2 Boiler Feedwater Supply and Storage

5.3.3.3 Boiler Water Treatment System

5.3.3.4 Cooling Water System

5.3.3.5 Instrument and Plant Air System

5.3.3.6 Flare System

5.3.3.7 Nitrogen System

5.3.3.8 Propane System

5.3.4 Waste Water Treatment (Area 1000)

5.4 Electrical Distribution

5.5 Instrumentation

5.5.1 Digital Control System (DCS)

5.5.2 Continuous Emission Monitoring Syștem (CEMS)

5.5.3 Water Analysis

5.6 Fire Protection System

5.7 Buildings

5.8 Access Roads/Storm Water Treatment

5.8.1 Drainage and Erosion Control

5.8.2 Area Surfacing and Roads

6.0 ESTIMATED PLANT PERFORMANCE

7.0 APPENDICES

7.1 Equipment List

7.2 Process Flow Diagrams (PFDs)

7.3 Plot Plans

7.4 Heat and Material Balances 
This Public Design Report describes the Piñon Pine Project will be located at the Sierra Pacific Power Company's (SPPCo) Tracy Station near Reno, Nevada. The integrated gasification combined-cycle (IGCC) plant is designed to process 880 tones per day (TPD) of bituminous coal producing approximately 107 gross megawatts of electric power (MWe). This project is receiving cost-sharing from the U.S. Department of Energy (DOE) in accordance with DOE Cooperative Agreement DE-FC2192MC29309.

The plant incorporates the Kellogg-Rust-Westinghouse (KRW) fluidized bed gasification technology which produces a low-Btu gas which is used as fuel in a combined cycle power plant which has been modified to accommodate the fuel gas produced by an air-blown gasifier. The gasification system also includes hot gas removal of particulates and sulfur compounds from the fuel gas resulting in a plant with exceptionally low atmospheric emissions. Desulfurization is accomplished by a combination of limestone injection into the KRW fluidized bed gasifier and by a transport reactor system. Particulate removal is accomplished by high efficiency cyclones and a barrier filter.

The Piñon Pine Project Schedule is divided into three phases as shown in the Project Schedule on the following Page. Phase I includes permitting and preliminary design. Phase II, which overlaps Phase I, covers detailed design, procurement, and construction. Phase III will cover the initial operation and demonstration portion of the project.

The Budget Periods are also shown on the Project Schedule along with major project milestones. Budget Period $1(\$ 42,980,000)$ funds permitting and pre-design. Budget Period $2(\$ 186,681,000)$ covers detailed engineering, procurement, construction, and start-up. Budget Period $3(\$ 104,690,000)$ will fund the operation and demonstration phase.

\subsection{PROGRAM BACKGROUND}

In January 1991, the DOE issued a Program Opportunity Notice (PON) soliciting proposals to demonstrate clean coal technologies that were capable of being commercialized in the 1990's. These technologies were to be capable of achieving significant reduction in the emissions of sulfur dioxide and/or nitrogen oxides and to provide for future energy needs in an environmentally acceptable manner. In response to the PON, DOE received proposals for projects that involved both advanced technologies that can be "retrofitted" to existing facilities and "re-powering" technologies that increase plant generating capacity, extend the operating life of a facility, and also reduce air pollution. The Piñon Pine Project proposed by SPPCo of Reno, NV was one of the nine projects selected for funding. The scope of theproject provides for the design, construction, and operation of an air blown KRW fluidized bed coal gasifier IGCC demonstration plant.

The Piñon Pine Project integrates a number of technologies fostered by DOE. Among these are the $\mathrm{KRW}$ fluidized-bed gasifier, in-bed desulfurization using limestone sorbent, and zinc based sorbent sulfur removal from a hot gas stream. DOE and its predecessor agencies have supported development of this fluidized-bed gasification technology since 1972 when the design of a process development unit 


\section{Total Project (96 Months)}

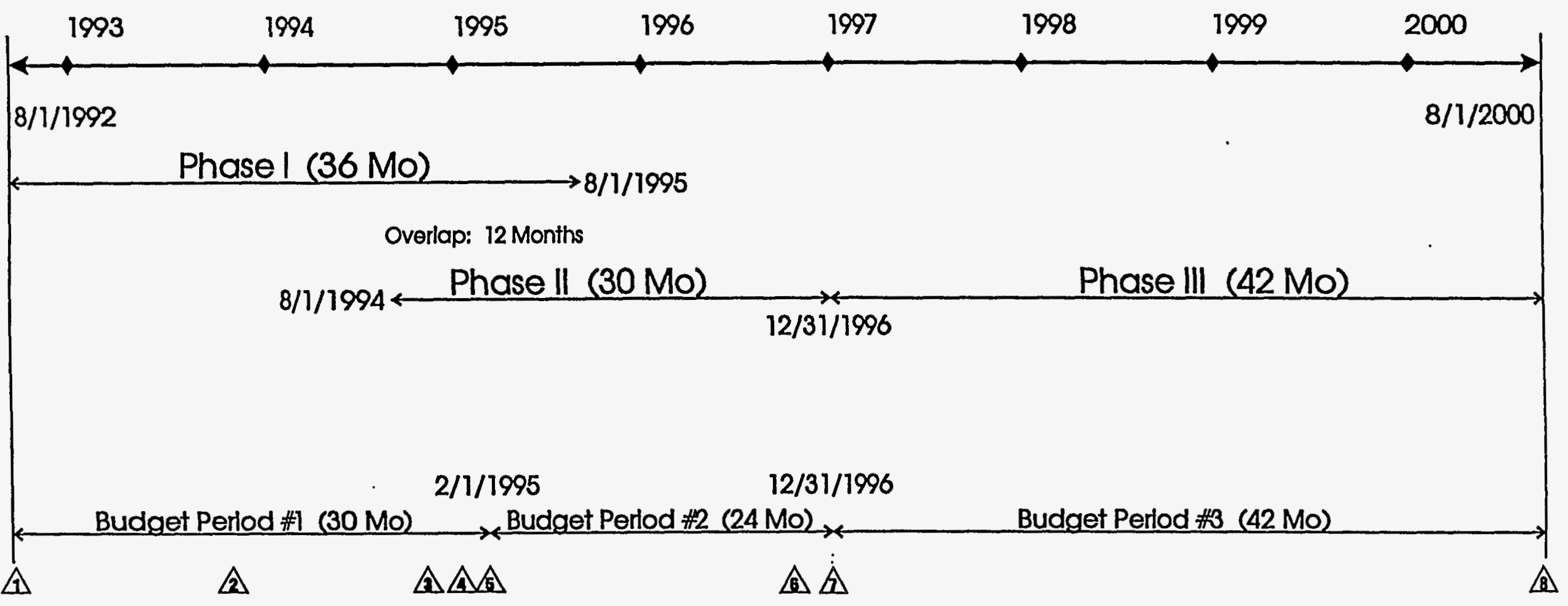

Milestone Description

4 Project Starts $-8 / 1 / 1992$

(2) PSCN Approves Project - 10/25/1993

3 NEPA Completed-Record of Decision 11/8/1994

4. UEPA / Permits Approved - 1/4/1995
Mllestone Description

今 Construction Starts - 2/21/1995

(1) Construction Complete - 10/17/1996

A Startup Complete - 12/31/1996

A. Testing Complete $-8 / 1 / 2000$

\section{Piñon Pine IGCC Power Project Schedule}


(PDU) was first initiated under contract with Westinghouse Electric Corporation. Construction of the PDU was completed in 1975 at Westinghouse's Waltz Mill Facility near Madison, Pennsylvania. From 1984 to 1988 the addition of dolomite and limestone sorbents to the gasifier bed for in-bed sulfur removal was successfully demonstrated at the PDU. These tests indicated that 85 to 90 percent sulfur removal efficiencies could be routinely achieved while using coal feedstocks containing 2 to 4.5 percent sulfur. In addition, the use of these sorbents in the gasifier was found to increase the product gas heating value while decreasing the production of ammonia, a major contributor to $\mathrm{NO}_{\mathrm{x}}$ (oxides of nitrogen) emissions.

The Cooperative Agreement between SPPCo and the DOE was executed in August 1992. Foster Wheeler USA Corporation (FW USA) is providing engineering and construction management services for the project. The M. W. Kellogg Company (MWK) is providing engineering for the gasifier island. Start of construction is expected to begin by February 21, 1995 with operation scheduled for December 31, 1996.

\subsection{TECHNOLQGY OVERVIEW}

The Piñon Pine Project located at SPPCo Tracy Station will incorporate the KRW gasification technology which produces a clean low-Btu gas for use as fuel in a combined cycle power plant for production of low cost electricity in an environmentally sound manner.

The KRW process improves upon first generation IGCC technology in several aspects. Its pressurized, air-blown fluidized bed gasification technology will provide'a higher thermal efficiency than a similar oxygen-blown system because it will consume less auxiliary power. A portion of the sulfur pollutants will be captured within the fluidized bed before they can exit the gasifier. Additional impurities will be removed through an advanced hot gas cleanup system which will operate with a regenerative sulfur sorbent to remove sulfur compounds, and with barrier filters to remove particulates. In addition, the inherent modular design of the system and simple process configuration will yield significantly lower engineering and construction costs.

Almost all of the previous IGCC demonstration plants were designed around a more conventional approach, i.e., gas produced in the gasifier was either quenched or cooled and scrubbed for low temperature removal of sulfur compounds. These plants also removed ash/slag in a wet state. In order to limit the size of cool down trains and desulfurizer systems, gasifiers for these early plants were oxygen blown, thereby adding to capital cost and parasitic power consumption. Cooling of gas for sulfur removal not only lowered the cycle efficiency, but also required extensive equipment and handling of process water.

In order to meet challenges of the market place and environment, a simplified IGCC system incorporating air-blown gasification with hot gas cleanup has been developed. By eliminating the oxygen plant and minimizing the need for gas cooling and wastewater processing equipment, the capital cost was reduced and plant efficiency improved. Key features of the simplified IGCC system are described below: 


\section{- Air-Blown Gasification}

In the simplified IGCC system, about 15 to 20 percent of the gas turbine compressor discharge air will be extracted for use as oxidant in the gasifier. A booster air compressor increases the pressure of this extracted air to compensate for pressure losses through the gasifier and downstream hot gas cleanup system and fuel control valve.

\section{- Hot Gas Cleanup}

To date, most major gasification plants have utilized cold (wet) cleanup processes. The alternate approach of filtering the gas at high temperature enables the gas to maintain most of the sensible heat resulting in a higher plant efficiency. Equipment will be minimized and there will be no waste water production. Several types of filtering devices have been tested in pilot facilities and are available from several suppliers.

\section{- Hot Gas Desulfurization}

Sulfur contained in coal will be removed in two steps. Addition of limestone to the gasifier will capture the hydrogen sulfide produced in the reducing environment of the gasifier. Sulfur not captured by the limestone will leave with the product gas and be removed in an external desulfurizer system.

\section{- Sulfation}

Coal ash with spent limestone (LASH) contains calcium sulfide (CaS) along with unconverted carbon. The sulfator will oxidize the $\mathrm{CaS}$ produced in the gasifier into calcium sulfate $\left(\mathrm{CaSO}_{4}\right)$, combust unconverted char and absorb sulfur dioxide $\left(\mathrm{SO}_{2}\right)$ in regeneration gas from the external desulfurizer system. Small amounts of transport and depressurization gas will also combust in the sulfator. The sulfator will operate as a fluidized bed. The heat generated will be removed by generating steam to maintain the bed material at a temperature of $1600^{\circ} \mathrm{F}$. Additional heat will be recovered from flue gas exiting the sulfator by generating and superheating steam. The sulfated lash will be suitable for landfill. Results from the on-going bench scale testing are being used to develop design data.

\subsection{DESIGN CONSIDERATIONS}

\subsection{Location and Description of Site}

The site selected for the Piñon Pine Project will be the existing Tracy Power Plant located approximately 17 miles east of Reno, Nevada.

Tracy is a 724-acre site located in a rural portion of Storey County, Nevada, approximately 17 miles east of the Reno/Sparks area (population 250,000) and 15 miles west of the Town of Fernley (population 7,000 ) Nevada. U.S. Interstate 80 is immediately adjacent and provides easy access to the site. The site is capable of accommodating the gasification plant, power plant facilities and all support facilities, with minimal site work. 


\subsection{Area Geology}

The proposed site is located in the Truckee River Canyon. Late during the Pleistocene Epoch, the Truckee River Canyon was occupied by Lake Lahontan, which covered an area extending approximately $40.2 \mathrm{~km}$ (25 miles) south from Pyramid Lake. As the lake receded, the Truckee River began to downcut into the lake deposits and subsequently formed the present canyon. Where the river eroded away the lake sediments, it deposited fluvial channel (beds of river materials) and overbank deposits in their place. As a result, near-surface sediments at the site are composed primarily of river deposits consisting of minor clays, silts, sands, gravelly sands, sandy gravels, and coarse gravels. Lake deposits of clay, silt, sand, gravel, and calcareous tufa (porous stone containing calcium) may occur beneath the site. The most recent deposits are relatively thin eolian (windblown) deposits of silt and fine sand that mantle (cover) portions of the surface.

The hills south of the site consist largely of olivine basalt (rock of volcanic origin containing a mineral silicate of magnesium and iron) and hornblende andesite (mineral consisting of silicate of calcium, magnesium, and iron in fine-grained volcanic rock) flows of the Pleistocene Kate Peak Formation, which provided much of the material that presently fills the canyon. The site itself is relatively level to very gently rolling terrain with moderate relief. The site elevation is highest toward the south and gently slopes to the north toward the Truckee River. Relief in the surrounding area varies from very low in some of the intermountain basins to quite high in the adjacent mountain ranges. The average elevation at the site is approximately 1,295 meters ( 4,250 feet). Typical elevations of the nearby basins are between 1,219 and 1,829 meters ( 4,000 and 6,000 feet); elevations at the tops of bordering mountain blocks range between 1,829 meters and 2,438 meters $(6,000$ and 8,000 feet). The major structural elements in the general region surrounding the site are the Pah Rah Range to the north; the Virginia Range to the south; the Walker Lane Fault Zone to the northeast; and the Olinghouse Fault Zone, which trends east west along the southern flanks of the Pah Rah Range.

The Tracy Power Station project site is located in the western part of the Great Basin Tectonic Province. The site is located about $40.2 \mathrm{~km}$ ( 25 miles) from the adjacent Sierra Nevada Tectonic Province. This location, in a transition zone between two tectonic provinces, is one of the most seismically active (Seismic Zone 4) and complex regions of the United States.

Based on seismicity and style of faulting, the western Great Basin has been divided into three subprovinces (Selmmons, 1980): (1) the transition between the Sierra Nevada Frontal Fault Zone and the Walker Lane Fault Zone: (2) the Walker Lane Fault Zone: and (3) the Great Basin Zone east of Walker Lane Fault Zone. The Walker Lane Fault Zone is a 32.2-km (20 mile) wide, northwest trending zone of mainly right-lateral faults that extend from near Walker Lake northwest through Pyramid Lake and into the Modoc Plateau of California. North of Pyramid Lake, the faults tend to radiate more northward and the Walker Lane Fault Zone becomes wider and more diffuse overall. The Walker Lane faults south of Pyramid Lake are relatively quiet compared to the faults in the other sub provinces, although active faults are abundant in northeast California. The closest active fault to the site within the Walker Lane is the Pyramid Lake strand, which is approximately $22 \mathrm{~km}$ (15 miles) from the site. It has 
an estimated Maximum Credible Earthquake value of 7.5. (A maximum credible earthquake, MCE, is the most serious earthquake that can be hypothesized from known geologic characteristics.)

East of the Walker Lane Fault Zone, faults are generally north-south trending normal faults. This part of the Great Basin has had several historic earthquakes of magnitude 6.6 to 7.7, including the 1954 Rainbow Mountain Fairview Peak, and Dixie Valley earthquakes. Epicenters along the Dixie ValleyFairview Peak area continue south across the Walker Lake Fault Zone and intersect the Sierra Nevada Frontal Fault Zone. Forty-four earthquakes of magnitude greater than 5.0 have been reported in the area between 1852 and 1992.

The Truckee-Verdi-Reno-Olinghouse Transverse Fault Zone is of particular concern because it passes near the proposed site and includes the Olinghouse Fault Zone. The active portion of the Olinghouse Fault Zone extends from $16 \mathrm{~km}$ ( 10 miles) east of Reno along the north side of the Truckee River Canyon, passes through Olinghouse Canyon, and abruptly arcs to the northeast to terminate against a fault of the Walker Lane Fault Zone for a total length of $23 \mathrm{~km}$ (14 miles). In 1869, a series of earthquakes with magnitudes up to 6.7 occurred along this fault producing surface rupture north, west, and east of Tracy. This fault is located approximately $1.6 \mathrm{~km}(1 \mathrm{mile})$ from the proposed site at its closest approach; it has an estimated Maximum Credible Earthquake value of 7.1.

The largest historical seismic events close to the project site are the 1852 event with a possible magnitude of 7.0 and the three December 1869 earthquakes with estimated magnitudes of between 5.5 and 6.7. The 1852 earthquake was located just south of Tracy Station; however, the precise location of the earthquake has not been determined because information is based solely on descriptions by members of the Paiute Indian Tribe who were camping south of Pyramid Lake near Wadsworth. The epicenters of the 1869 earthquakes were located on the Olinghouse Fault Zone 16 to $39 \mathrm{~km}$ (10 to 24 miles) east of Reno. This zone is where the surface rupture occurred and includes the closest approach of the fault to the site.

The extent of wetlands is sufficiently limited to the extreme northern portion of the property and, siting new facilities has been done to avoid permanent wetland disturbance. A temporary fence was erected to restrict construction activities within the wetlands.

\subsection{Environmental. Safety and Hazard Considerations}

The Piñon Pine Project will comply with environmental, health, safety and socioeconomic (EHSS) statues and regulations. The probability of EHSS compliance is essentially assured. EHSS risks will be minimized. Health and safety plans were based on existing experience, and are referenced. Adverse environmental impacts will be at acceptable levels, and socioeconomic impacts will be beneficial. Mitigation measures identified in the Final Environmental Impact Statement (EIS) have been incorporated into the Record of Decision. All other midigation actions will be completed concurrent with plant construction.

EHSS compliance for the Piñon Pine Project is essentially assured because of the understanding of permit and regulatory requirements, and the adherence to safety regulations and codes. 
Construction and operation of the Piñon Pine Project will be undertaken in a safe manner and in compliance with the general requirements of the Occupational Health and Safety Act (OSHA) PL 91596, Part 1926 for construction and Part 1910 for operating.

Hazardous wastes will be handled in full compliance with OSHA Standard 29 CFR Part 1910.1200. These requirements relate to the Hazard Communication/Right-to-Know Program.

Presently there are no specific OSHA requirements in Nevada for the protection of workers in gasification plants. Guidelines for workers health and safety at coal gasification facilities have been recommended by the National Institute of Occupational Safety and Health (NIOSH) in:

- $\quad$ "Recommended Health and Safety Guidelines for Coal Gasification Pilot Plants", Department of Health, Education and Welfare (DHEW) (NIOSH) Publication No. 78-120, January 1978.

- $\quad$ "Criteria for Recommended Standard, Occupational Exposure in Coal Gasification Plants", DHEW (NIOSH) Publication No. 78-191, September 1978.

\subsection{Supplied Utilities}

\subsubsection{Coal Supply}

The gasifier is designed to operate with a wide variety of coäls. For each coal property, there is a considerable range acceptable to the gasifier. The flexibility of fuel supply is a major advantage of this process. During the operation of the Piñon Pine Project the predominant fuel will be low sulfur coals from the western U.S., with high sulfur coals from areas such as Pennsylvania being used for demonstration tests. The western coals used will be sub-bituminous and bituminous coals such as those found in Utah, Colorado, Wyoming, and Montana.

Coal in these states is abundant. Supplies will not only be available for the life of this project, but will also be available into the future. Currently, coal in this region is in an oversupply situation that has driven market prices down to levels last seen in the 1960's. SPPCo's economic forecast for fuel prices projects that these coal prices will remain stable in the future, and will not increase at rates exceeding general inflation.

SPPCo has interviewed major coal producers in the area who are able to supply required quantities from existing facilities at attractive prices.

All deliveries will be made by railcar to the Tracy facility. There are facilities of the Southern Pacific Railroad currently on-site. 


\subsubsection{Limestone}

Sorbent requirements for in-bed desulfurization have been evaluated for the life of the project. High quality limestone supplies suitable for project needs are available from several active producers in Nevada and western Utah. Although a variety of sorbents of various qualities are suitable for use as sorbents in the gasification process, optimum sulfur removal efficiency will be achieved with maximum concentration of calcium carbonate.

Project requirements are approximately 80 tons/day of $90 \%+$ calcium carbonate $\left(\mathrm{CaCO}_{3}\right)$ limestone. The material will be delivered to the site as limestone sand, $16 \times 200$ mesh, maintained dry so that no additional preparation is needed prior to injection into the gasifier. Dust-free truck transportation and storage will be incorporated.

\subsubsection{Natural Gas}

Start-up and emergency backup fuel will be provided by a 12" diameter pipeline, pressurized at nominal 500 psia utilized to provide natural gas to the combustion turbine. This line is on-site and connected to the Paiute gas transmission line at the plant boundary. The Paiute transmission line is the main line to the Reno area, and its transmission capacity will accommodate the requirements of the project except for brief periods during the winter when use of natural gas for electric power generation is curtailed. During these periods, propane will be utilized.

\subsubsection{Electric Power}

The plant is within SPPCo's service area. Construction power will be provided from existing buses, with electric power of $4.1 \mathrm{KV}$, approximately 100 feet from the project boundary.

\subsubsection{Water Requirement and Availability}

For the project, cooling water make-up will be taken from the existing cooling pond which is supplied from the Truckee River which adjoins the site, using an additional pump and existing water rights. Raw water for the demineralization train will be taken from existing deep wells. SPPCo serves water to 53,000 customers in northern Nevada and has extensive water management experience throughout the region. Sufficient water rights exist to provide the Tracy site with the required water for the gasification process, the steam cycle, the cooling water and the balance of the plant through the year 2030 .

\subsubsection{Transportation System}

Both highway and rail transportation will be used during the construction and operation phases of the project. The property is adjacent to I-80, a four-lane interstate highway. The site is served by the main line of the Southern Pacific Railroad which runs through the property. An extended rail spur for coal transport will be provided. Air transportation is available through Reno Tahoe International Airport, a major airport located in Reno approximately 20 miles from the Tracy site. 


\subsubsection{Solid Waste Handling}

Cooled solid waste consisting of ash, fines and sulfated limestone from the sulfation unit will be conveyed continuously to the solid waste storage silo.

The solid waste material in the silo will be loaded onto trucks by gravity during the day shift operation, 5 days per week. The silo will be equipped to minimize dusting during the truck loading operation. The solid waste will be hauled to the lined landfill located approximately $2,000 \mathrm{ft}$. southeast of the process area. A local landfill has expressed interest in using the material as cover.

The solid waste silo will be sized for three days of storage to handle the solid waste production over the weekend without the need of the truck load-out operation.

\subsection{PLANT DESCRIPTION}

The major systems of the Piñon Pine Project IGCC facility are described in this section of the report. Equipment List, Process Flow Diagrams, Plot Plans, and Heat and Material Balances are included in the Appendices.

\subsection{Combined Cycle}

\subsubsection{Gas Turbine Generator (Area 700)}

A General Electric Model MS6001FA Gas Turbine Engine (70.1 MW International Standards Origanization (ISO) rating) has been selected as the prime mover for the Piñon Pine Project. The engine's output shaft power will be reduced in rotative speed in a gearbox, from the optimum-efficiency value for a gas turbine of this size to 3600 Revolutions per minute (RPM). Mechanical power will then be converted to electrical power in a once-through air-cooled synchronous generator.

The gas turbine generator's, GT701, operating characteristics using syngas fuel at annual-average ambient air conditions $\left(50^{\circ} \mathrm{F}, 12.56 \mathrm{psia}, 20 \%\right.$ relative humidity $\left.(\mathrm{RH})\right)$ are approximately as follows:

Output:

Heat Input:

Exhaust to heat recovery steam generator (HRSG):

$$
\begin{aligned}
& \text { 60,990 kilowatts }(\mathrm{kW})^{(1)} \\
& \text { 568.4 MMBtu/hr }
\end{aligned}
$$

flow: $1,422,000 \mathrm{lb} / \mathrm{hr}$

temp: $1,103^{\circ} \mathrm{F}$

(1) = at the generator terminals, 0.85 power factor $(\mathrm{pf})$

(2) $=$ chemical release, i.e. does not include syngas sensible heat 
Available thermal energy in the exhaust gases will be captured in a heat recovery steam generator, SG801, (Section 800) to drive a condensing steam turbine generator.

The gas turbine will be an eighteen stage axial flow compressor with modulated inlet guide vanes. Interstage extraction will be used for turbine nozzle and wheelspace cooling. Because the blading material in the compressor will have high corrosion resistance, a coating will not be required.

Approximately $20 \%$ of the total compressor discharge air will be extracted from the engine for the airblown gasifier, and return as part of the syngas fuel.

The gas turbine engine will be provided with a conventional array of auxiliary systems and accessory devices, supplemented where necessary by special provisions for gasifier air extraction and combustion of syngas. Gas turbine auxiliary systems and accessory devices include:

- Load gear

- Synchronous generator

- Excitation system

- Control panel

- Fuel system

- Lubrication oil system

- Starting system

- Inlet air/evaporative cooler system

- Compressor cleaning system

- Fire protection system

- Noise abatement

\subsubsection{Steam Turbine Generator and Heat Recovery Steam Generator (Area 800)}

\subsubsection{Heat Recovery Steam Generator}

A heat recovery steam generator (HRSG), SG801, will be provided to recover the heat in the gas turbine exhaust gas stream. Two (2) levels of steam will be generated:

Level $1 \quad 1006.7$ psia

Level $2 \quad 59.1$ psia

Steam generated in the HRSG at $1006.7 \mathrm{psia}$, and high pressure steam generated in the gasifier island, will be combined, superheated in the HRSG and sent to the steam turbine generator at $950 \mathrm{psia}, 950^{\circ} \mathrm{F}$ for expansion. The 59.1 psia steam generated will be superheated and sent at $55 \mathrm{psia}, 360^{\circ} \mathrm{F}$ to the deaerator, DH801, for heating and stripping with the excess sent to the steam turbine generator, TG801.

The following items will be included in the HRSG:

Item No. Description

D801 High Pressure Steam Drum 


\section{D802 Low Pressure Steam Drum \\ DS801 Main Steam Attemperator}

\subsubsection{Stack}

The exhaust gasses exiting the steam generator and gasifier island will vent to the atmosphere via a $28^{\prime}$ dia. $\times 225^{\prime}$ high concrete shell stack.

The stack, ST801, will contain two (2) insulated steel flues; one (1) 13' dia. and one (1) 4' dia.

The 13' dia. flue will be dedicated to gas turbine exhaust while the remaining flue will be dedicated to the gasification plant. The stack shall be equipped with test ports, interior access, lighting, aviation warning lights and lightning protection.

\subsubsection{Steam Turbine Generator}

The steam turbine generator, TG801, will be a condensing type unit with extraction at nominally 485 psia providing steam, after pressure control and desuperheating to the gasifier at $420 \mathrm{psia}, 700^{\circ} \mathrm{F}$. High pressure steam letdown will be used if and when low throttle steam rates cause the extraction pressure to fall below that required to provide 420 psia steam. This letdown will provide steam for injection to the gas turbine generator at $420 \mathrm{psia}, 700^{\circ} \mathrm{F}$ for $\mathrm{NO}_{\mathrm{x}}$ control when operating on natural gas or propane fuel.

The steam turbine will exhaust into a surface condenser, E801. Cooling water from Section 1200 will condense the exhaust steam at 2 inches of mercury pressuge (in. $\mathrm{Hg}$ ), based on normal gasifier load at 50 - $F$ ambient temperature. Condensate will be pumped from the condenser by the hotwell condensate pumps, P801 A/B, through the condensate preheater in the HRSG for the recovery of low level heat and thence to the deaerator. Venting of the condenser will be accomplished by a vacuum pump system.

High pressure boiler feed water (BFW) will be pumped from the deaerator to the high pressure evaporator and Section 300 , Gasification, and Section 600 , Sulfation by the high pressure BFW pumps, $\mathrm{P} 803 \mathrm{~A} / \mathrm{B}$. High pressure $\mathrm{BFW}$ to the high pressure evaporator will be preheated in an economizer section of the HRSG. Deaerated low pressure BFW will be pumped to the low pressure evaporator by the low pressure BFW pumps, P802 A/B. BFW to the low pressure evaporator will be preheated in an economizer section of the HRSG.

The steam turbine generator will have an output of $46,226 \mathrm{~kW}$ at a power factor of $.85,329,133 \mathrm{lb} / \mathrm{hr}$ throttle flow, 11,855 lb/hr extraction @ $485 \mathrm{psia}, 15,304 \mathrm{lb} / \mathrm{hr}$ induction at $54 \mathrm{psia}$ and $360^{\circ} \mathrm{F}$ and 2.0 inches of mercury absolute pressure (in.HgA) exhaust backpressure.

A deaerator, DH801, shall be supplied to deaierate returned condensate and demineralized water makeup.

In addition, the following equipment shall be provided in the steam generation system: 


\begin{tabular}{ll} 
Item No. & Description \\
\hline DS802 & M.P. Steam Desuperheater \\
DS803 & Pegging Steam Desuperheater \\
E802 & Gland Condenser \\
P804A/B & Vacuum Pumps \\
D803 & Continuous Blowdown Drum \\
D804 & Intermittent Blowdown Drum
\end{tabular}

\subsection{Gasifier Island}

The gasifier island is based on utilizing a KRW air blown, fluidized-bed coal gasifier to produce a fuel gas for use by the combustion gas turbine which will utilize a low Btu fuel gas. During normal base load operation, the gasification system will:

1. Produce: $285,000 \mathrm{lb} / \mathrm{hr}$ syngas with a heating value of $129 \mathrm{btu} / \mathrm{scf}$

2. Export: $156,000 \mathrm{lb} / \mathrm{hr}$ of steam for power production to the combined cycle area

3. Consume: 880 TPD Raw Coal

4. Discharge: 120 TPD of LASH (limestone/ash mixture) for deposit to landfill

\subsubsection{Coal Gasification (Area 300)}

This area will contain the solids feed system and the gasifier with its associated cyclone. Solids feeds will consist of the coal to be gasified and limestone sorbent used for capture of sulfur compounds emitted during gasification.

Coal and limestone (as well as coke breeze during start-up) will be fed from a single conveyor to the atmospheric feed surge bin, BN301, which will be equipped with the feed surge bin vent filter, F302, to capture fugitive dust. This bin will periodically discharge solids into the feed pressurization hopper, BN302. After transfer of solids into BN302, it will be isolated from BN301 and pressurized with air from the air receiver, D301. Pressurization will be done through the hopper vent filter, F301, which back flows solids collected during the depressurization step back into BN302. After pressure equalization with the feed hopper, BN303, solids will be transferred from BN302 to BN303. When BN302 is empty, it will be isolated and depressurized to begin the next cycle. The feed hopper, BN303, will never be emptied.

The feed hopper, BN303, will provide a continuous feed of coal and limestone to the gasifier through the coal feeder, FD301. Solids from the feeder will be picked up by transport air from E204 and fed directly into the gasifier central feed tube. Additional air from the recuperator, E201, will be fed through the same feed tube and the streams merge to form a central jet where the coal will quickly devolatilize, with the remaining char and limestone entering the bed. Combustion of char and gas will occur within the jet to provide heat necessary for endothermic devolatilization, gasification and desulfurization chemical reactions. Extraction steam from the steam turbine will be fed to the gasifier bed. Steam will be 
injected at the gasifier grid to aid in fluidization of the gasifier bed. The primary gasification and combustion reactions whichwill occur in the gasifier are:

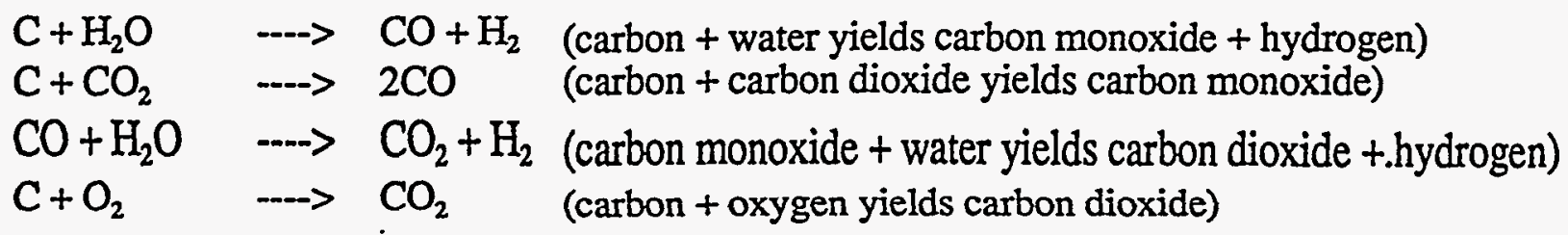

Carbon monoxide and hydrogen will form the major combustible constituents of the product gas. Methane and other hydrocarbons will be produced in lesser quantities, primarily from the devolatilization process. The operating temperature of the gasifier will be sufficiently high to crack any tars or oils that might be produced.

Gasification will result in the release of sulfur from the coal, primarily in the form of hydrogen sulfide $\left(\mathrm{H}_{2} \mathrm{~S}\right)$. At gasifier operating conditions (nominal $295 \mathrm{psia}$ and $1800^{\circ} \mathrm{F}$ gas exit), the limestone sorbent fed with the coal will quickly calcine and react with the $\mathrm{H}_{2} \mathrm{~S}$ according to the following reactions:

$\mathrm{CaCO}_{3} \quad--\rightarrow \quad \mathrm{CaO}+\mathrm{CO}_{2} \quad$ (calcium carbonate yields calcium oxide + carbon dioxide) $\mathrm{CaO}+\mathrm{H}_{2} \mathrm{~S} \quad-.->\mathrm{CaS}+\mathrm{H}_{2} \mathrm{O} \quad$ (calcium oxide + hydrogen sulfide yields calcium sulfice + water)

The amount of $\mathrm{H}_{2} \mathrm{~S}$ that will be captured is limited by chemical equilibrium. With the low sulfur Southern Utah Fuel Company (SUFCO) coal, approximately $50 \%$ of the sulfur released from the coal will be removed from the gas by reaction with $\mathrm{CaO}$. Sulfur exiting the gasifier in gaseous form will be captured by the external desulfurizer system in Area 600.

The product gas which will exiting the top of the gasifier will contain a significant quantity of entrained solids, consisting of char (unconverted coal), ash, and sorbent. The gas will enter the gasifier cyclone, S301, which will remove most of the solids. Gas from the cyclone will be directed to the product gas cooler, E401, and the product gas trim cooler, E403, for heat recovery.

Solids collected in the gasifier cyclone, S301, will be returned to the gasifier via the dipleg. Recycle gas from the recycle gas compressor, C901, will be used to fluff the dipleg to facilitate flow of solids back to the gasifier bed. Recycle gas will be used to provide fluidization gas and for cooling of the spent solids in the annulus at the bottom of the gasifier.

As carbon in char is consumed, the particles will become enriched in ash. Ash particles tend to agglomerate, and along with dense calcium sulfide/oxide particles, separate from the char bed because of different density and fluidization characteristics. This separation will occur primarily in a region that surrounds the central feed tube at the bottom of the gasifier. These solids will be further cooled in the gasifier annulus by a counter current stream of recycle gas. The spent solids leaving the gasifier will be transferred via the ash feeder, FD302, to the ash collection hopper, BN501. 
The gasifier and sulfator start-up heater, $\mathrm{H} 301$, will heat the gas turbine extraction air to $1000^{\circ} \mathrm{F}$ for preheating the gasifier and downstream equipment during start-up.

\subsubsection{Oxidant Compression and Supply (Area 200)}

This area will provide air to the gasifier, air for regeneration of the desulfurization sorbent, air for coal and limestone feed pressurization and transport air for feeding coal and limestone into the gasifier.

Air for the gasifier island will be extracted from the gas turbine's air compressor. A portion of this air will be diverted for use during startup of the gasifier. The major portion of the air, which will be the oxidant feed to the gasifier, will have to be compressed above gasifier operating pressure. To minimize power consumption during compression, this air will be cooled to $120^{\circ} \mathrm{F}$ in three exchangers in series. E201 will be the air recuperator which reheats the gasifier air after compression. Further cooling will be done in the air precooler, E203, which will heat BFW, and the trim cooler, E202, which will use cooling water for the final gas cooling. The knockout drum, D201, will be provided downstream of the trim cooler to remove any water condensed from air during cooling. Any water collected will be sent to the waste water treatment system.

Air exiting the knockout drum will be compressed by the boost air compressor, C201, to above gasifier pressure level. A portion of this air will be cooled by cooling water in the transport air cooler, E204, and is split into two streams. One of the streams is used as transport air to feed solids into the gasifier. The other stream will be diverted to the suction of the pressurization air compressor, C301. The major portion of the air exiting the boost air compressor, C201, will be reheated in the air recuperator, E201, and again divided into two streams. A major portion of this stream will be fed to the gasifier while the other portion will be used for regeneration of the zinc oxide based desulfurization sorbent.

A portion of air exiting the transport air cooler will be compressed to about 600 psia by $C 301$ and sent to the pressurization air receiver, D301, which will dampen out compressor fluctuations and serve as a surge vessel. Air from D301 will be used directly for coal/limestone feed pressurization.

\subsubsection{Gas Stream Heat Recovery (Area 400)}

This area will include cooling of the main product gas from the gasifier as well as cooling of the recycle gas.

Product gas from the gasifier cyclone, $\mathrm{S} 301$, will be cooled to about $1000^{\circ} \mathrm{F}$ in the product gas cooler, E401, and the product gas trim cooler, E403. The rejected heat will generate steam from BFW supplied from the steam drum, SG401. Circulation through these two exchangers will be by natural convection.

The particulate free, desulfurized product gas exiting the hot gas filter, F501, is cooled in the recycle gas cooler, E402 by high pressure BFW. A portion of the cooled gas will be used for solids transport in the sulfator system. The major quantity will be sent to Area 900 (recycle gas compression) for further treatment. 
The gasifier steam drum, SG401, will operate at 1075 psia (nominal) and will be supplied by BFW from Area 800 . Steam from the gasifier steam drum will be combined with superheated steam from the HRSG steam drum, D602, and passed through the superheater section of the HRSG, SG602, in order to superheat it to $600^{\circ} \mathrm{F}$ prior to delivery to Area 800 . Blowdown from the gasifier steam drum will be combined with blowdown from the HRSG steam drum and also returned to Area 800 .

The high pressure $\mathrm{BFW}$ at $230^{\circ} \mathrm{F}$ from Area 800 will be split into several streams. A portion will be sent directly to the air precooler, E203, and the recycle gas cooler, E402. Heated BFW exiting these exchangers will be routed to the gasifier steam drum. The remaining BFW from Area 800 will flow directly into the gasifier steam drum, SG401, and the HRSG steam drum, D602. Some BFW from SG401 will flow to the regenerator effluent gas cooler, E607. The mixture of BFW and steam exiting E607 will flow back to SG401. BFW entering the sulfator steam drum will be preheated in the economizer section of SG602.

\subsubsection{Gas Stream Particulate Removal (Area 500)}

This area will provide final cleanup of particulates in the product gas stream and collection of all spent solids prior to final processing.

Desulfurized product gas from the desulfurization section will contains a small quantity of particulates. This stream will be sent to the hot gas filter, F501, which essentially removes all of the remaining particulates. The hot gas filter will be a ceramic candle type utilizing back pulse gas for cleaning. Candle elements used for filtration will be housed in a steel vessel with access capability for replacement of candles. The particulate free desulfurized gas exits the filter and will be sent to the gas turbine.

Blowback gas for cleaning of the filter elements will be provided from the recycle gas receiver, D901. Fines removed by the filter elements will be collected in the bottom of the filter vessel and discharged through the filter fines screw cooler, E501, which will cool the fines prior to discharging them into the filter fines collection hopper, BN503. Cooling will be accomplished in E501 by a closed heat transfer fluid system, PG501, which will be cooled by cooling water. The collected fines will be sent to the filter fines collection hopper, BN503, for further processing.

Hoppers BN501/502/508 and BN503/504/507 will be parallel systems for collection of feed ash and filter fines, respectively. Ash collected in BN501 will be ischarged into the ash depressurization hopper, BN502, which will be pressurized with high pressure recycle gas from the recycle gas receiver, D901. Pressurization will be done through the ash vent filter, F502, which will serve as a particulate filter during the depressurization cycle. Ash from BN502 will be discharged into the ash feed hopper, BN508, from where will be continuously transported to the sulfator by cooled recycle gas stream. The fines collection and feed system will be operated in a similar manner utilizing the filter fines collection hopper, BN503, filter fines depressurization hopper, BN504, filter fines feed hopper, BN507, and the filter fines vent filter, F503. Filter fines from BN507 will be conveyed by a stream of recycle gas to the fines combustor, H602. Vent gas from the ash depressurization hopper and the filter fines depressurization hopper will be routed to the sulfator. 


\subsubsection{Desulfurization (Area 600)}

This area will desulfurize the product fuel gas prior to delivery to the hot gas filter, FG501, and condition the solids waste for disposal.

- Desulfurization (Fuel Gas):

Fuel gas from $\mathrm{E} 403$ will be fed to the fuel gas desulfurization system at approximately $1000^{\circ} \mathrm{F}$. Sulfur compounds will be removed from the gas by a zinc oxide based sorbent, which will contain nickel oxide, according to the following reactions:

\begin{tabular}{lll}
$\mathrm{ZnO}+\mathrm{H}_{2} \mathrm{~S}$ & $--->>$ & $\mathrm{ZnS}+\mathrm{H}_{2} \mathrm{O}$ (zinc oxide + hydrogen sulfide yields zinc sulfide + water) \\
$\mathrm{ZnO}+\mathrm{COS}$ & $--->$ & $\mathrm{ZnS}+\mathrm{CO}_{2}$ (zinc oxide + carbonyl sulfide yields zinc sulfide + carbon dioxide) \\
$\mathrm{NiO}+\mathrm{H}_{2} \mathrm{~S}$ & $--->$ & $\mathrm{NiS}+\mathrm{H}_{2} \mathrm{O}$ (nickel oxide + hydrogen sulfide yields nickel sulfide + water) \\
$\mathrm{NiO}+\mathrm{COS}$ & $--->$ & $\mathrm{NiS}+\mathrm{CO}_{2}$ (nickel oxide + carbonyl sulfide yields nickel sulfide + carbon \\
& & \multicolumn{1}{c}{ dioxide) }
\end{tabular}

The sulfur compounds in the product gas to the gas turbine will be reduced to less than 20 parts per million by volume (ppmv) and the mildly exothermic absorption reactions will result in a small increase in the fuel gas temperature.

The fuel gas desulfurization system will comprise a transport desulfurizer, R603, and a transport regenerator, R604. The fuel gas from E403 will be fed to the mixing zone at the bottom of the riser of R603 where it will mixe with zinc oxide based sorbent from the desulfurizer cyclone, S603, that will be recirculated to the riser via the standpipe. Absorption of gaseous sulfur compounds will take place in the narrower riser section as the fuel gas and sorbent flow upward and into S603.

The sorbent leaving the riser of R603 will be partially sulfided. Bulk separation of the gas and solid phases will take place in S603. The solids separated in $\mathrm{S} 603$ will be collected in the standpipe from where a portion of the sulfided sorbent will be transferred to the regenerator riser and the remainder will be recirculated to the reactor. The fuel gas leaving S603 will be desulfurized and flow to the hot gas filter, F501, where it will undergoe final particulate (fines escaping the gasifier cyclone and attrited sorbent) removal before being fed to the gas turbine.

Fresh sorbent from bulk storage will be dumped into the sorbent storage hopper, BN603, pressurized in the sorbent feed hopper, BN604, and fed to R603 via the standpipe to maintain sorbent inventory and reactivity. Sorbent fines escaping BN603 and BN604 will be collected in the sorbent storage hopper vent filter, F604, and the sorbent pressurization hopper vent filter, F605, respectively.

The stream of sulfided sorbent withdrawn from the standpipe will flow to the mixing zone at the bottom of the transport regenerator, R604. Regeneration air from E201 will be preheated in the sorbent regeneration air heater, $\mathrm{H608}$, and will be fed to the mixing zone of R604. The sulfided sorbent will be regenerated by air according to the following highly exothermic reactions as both the sorbent and air flow up the regenerator riser: 
$2 \mathrm{ZnS}+3 \mathrm{O}_{2} \quad--->\quad 2 \mathrm{ZnO}+2 \mathrm{SO}_{2}$ (zinc sulfide + oxygen yields zinc oxide + sulfur dioxide)

$2 \mathrm{NiS}+3 \mathrm{O}_{2} \quad--->2 \mathrm{NiO}+2 \mathrm{SO}_{2}$ (nickel sulfide + olygen yields nickel oxide + sulfur dioxide)

The temperature of the gas exiting the regenerator riser will be approximately $1200^{\circ} \mathrm{F}$ and will be controlled by varying the inlet temperature of the regeneration air, the circulation rate and sulfur loading of the sulfided solids. The mixture of regenerated sorbent and gaseous products of regeneration leaving the riser will enter the regenerator cyclone, $S 604$, where bulk separation of the solids and gaseous phases occur. The regenerated sorbent will be returned to the standpipe of $\mathrm{R} 603$. The $\mathrm{SO}_{2}$-rich gas from regeneration will be cooled in the regenerator effluent cooler, E607, and then routed to the sulfator, $\mathrm{R} 602$, for $\mathrm{SO}_{2}$ capture.

Sorbent withdrawal from the fuel gas regeneration system, if required, will normally be from the bottom of S604. However, at times when emergency dumping of solids is required, solids may also be drawn from the solids return leg on R603 standpipe or from the bottom of R603 mixing zone. The solids will be stored in the spent sorbent hopper, BN605, and will then be sent either to disposal or returned to BN603. BN605 will be provided with the sorbent depressurization hopper vent filter, F606, to capture any sorbent fines.

\section{- Waste Solids Treatment:}

With the exception of a small quantity of sulfur in the fuel gas to the gas turbine, all of the sulfur in coal will ultimately be disposed of in the sulfator system. This system will serve the following functions:

1. Combustion of residual char in the ash and fines collected from gasification.

2. Capture of $\mathrm{SO}_{2}$ from both the residual char combustion and the desulfurizer regeneration effluent gas.

3. Oxidation of calcium sulfide (CaS) produced in the gasifier to calcium sulfate.

The sulfur reactions which will occur in the sulfator can be represented by the following equations:

$\begin{array}{lll}\mathrm{S}+\mathrm{O}_{2} & --->\mathrm{SO}_{2} & \text { (sulfur }+ \text { oxygen yields sulfur dioxide) } \\ \mathrm{CaO}+\mathrm{SO}_{2}+1 / 2 \mathrm{O}_{2} & --->\mathrm{CaSO}_{4} & \text { (calcium oxide }+ \text { sulfur dioxide }+ \text { olygen yields calcium sulfate) } \\ \mathrm{CaS}+2 \mathrm{O}_{2} & -->\mathrm{CaSO}_{4} & \text { (calcium sulfide }+ \text { olygen yields calcium sulfate) }\end{array}$

All of these reactions are highly exothermic and may not proceed to completion. In addition, a small recycle gas stream (transport and pressurization gas) will be combusted in the sulfator.

The sulfator, R602, will be a bubbling bed reactor which will be fluidized by air supplied by the sulfator air compressor, C601. Solids exiting gasifier bottom which contain unconverted calcined limestone, sulfided limestone and ash (LASH) will be conveyed from the ash feed hopper, BN508, to the sulfator with cooled recycle gas from the recycle gas cooler, E402. Regeneration effluent gas from the desulfurization system will be fed to the sulfator for capture of $\mathrm{SO}_{2}$ by reaction with the unconverted calcined limestone in the solids from the gasifier. Provision will be made to add additional fresh limestone, from the limestone feed hopper, BN505. 
Instrument air will be used to pressurize BN505 to add fresh limestone to the sulfator during normal operation. Any fugitive dust from BN505 will be captured by the limestone feed hopper vent filter, F504. During the start-up, air from C601 will be preheated in the gasifier and sulfator start-up heater, $\mathrm{H} 301$, and passed through the sulfator and downstream equipment.

The sulfator will be operated at essentially atmospheric pressure. In order to maximize $\mathrm{SO}_{2}$ capture and sulfide oxidation, the sulfator temperature will be maintained at about $1600^{\circ} \mathrm{F}$. This will be done by generating saturated steam in the primary solids cooler, E605, which will be supplied with BFW from the HRSG steam drum, D602, by natural convection. Steam generated in E605 will be collected in D602.

Filter fines from BN507 will be conveyed by a stream of recycle gas to the fines combustor, $\mathrm{H} 602$, to burn off carbon for additional heat recovery. Air for combustion temperature control will be supplied by C601.

Flue gas leaving the sulfator will pass through the sulfator cyclone, S601, for removal of particulates and will then be mixed with flue gas from H602 prior to cooling in the HRSG, SG602, to about $300^{\circ} \mathrm{F}$. The gas will then pass through the sulfator flue gas bag house filter, F602, for final removal of particulates and will be sent to the stack.

Gas cooling in SG602 will be acheived by generating steam at 1075 psia and preheating BFW, respectively. Additional saturated steam will be generated in HRSG coils with BFW supplied from D602 by natural circulation. Deaerated BFW from Area 800 will be heated in the economizer section of SG602 prior to transfer to D602.

Saturated steam generated in HRSG and solids coolers will be collected in D602, mixed with steam from SG401 and passed through the superheater section of SG602 to superheat to $600^{\circ} \mathrm{F}$ (approximately $50^{\circ} \mathrm{F}$ superheat at battery limit pressure of 1025 psia) prior to exporting it to Area 800 .

Solids leaving the bottom of the sulfator will be cooled in the sulfator solids screw cooler, E602, and collected in the sulfator solids collection hopper, BN601. These will then be combined with solids collected in the sulfator flue gas bag house filter, F602, in the sulfator solids depressurization hopper, BN602, which will be pressurized by instrument air and collect solids from BN601. Solids from BN602 will be discharged on to a conveyor for transfer to Area 1100 .

\subsubsection{Recycle Gas Compression (Area 900)}

This area will provide for recompression and distribution of recycle gas to various users.

Recycle gas from the recycle gas cooler, E402, will be split into three streams. A portion will be sent directly to the sulfator system for use as transport gas. A second stream will be compressed by the recycle gas compressor, C901, to gasifier pressure for recycle directly to the gasifier and for use as fluffing gas in the desulfurizer riser. 
A third stream will be further cooled in the recycle gas booster compressor trim cooler, E901, to $120^{\circ} \mathrm{F}$ before compression. Cooling will result in condensation of a small amount of water from gas which will be removed in the recycle gas knockout drum, D902, and disposed to the sulfator. The cooled gas from D902 will be fed to the recycle gas booster compressor C902 which will boost the pressure to about 1750 psia. The high pressure gas will be sent to the recycle gas receiver, D901, which will act as a surge vessel. Gas from D901 will be used as blowback gas to clean the gas filter, F501, and also for pressurization of the ash depressurization hopper, BN502, and the filter fines depressurization hopper BN504. A small amount of this gas will be used for fluidization of the transport desulfurizer standpipe.

\subsection{Qffsites}

\subsubsection{Solids Receiving and Grinding (Area 100)}

\subsubsection{Raw Coal Receiving and Storage}

Raw coal, size $2^{\prime \prime} \times 0$, will be received at the plant from a unit train consisting of up to eighty-four 100 ton railcars every seven days. The coal will be received at the unloading station and transferred to the coal storage dome. The unloading station will be enclosed and provided with a dust collection system to avoid uncontrolled coal dust emissions. The unloading station will consist of two receiving hoppers, each equipped with belt type unloading feeder which will feed the raw coal to the raw coal transfer conveyor. Coal will be weighed in transit by the raw coal receiving scale located at the tunnel exit of the raw coal transfer conveyor. A sweep type automatic sampling system will be installed on the coal transfer conveyor, and located after the conveyor tunnel exit, to collect a representative raw coal sample to determine the quality of coal received. The raw coal unloading and conveyor system will be sized to handle an 84 railcar train unloading operation in a four-hour period, at a design rate of 2,250 std. tons $/ \mathrm{hr}$. The raw coal receiving system will consist of the following major components:

\begin{tabular}{lll} 
Item No. & Description & \multicolumn{1}{c}{ Duty } \\
\hline BN101A/B & Raw Coal Receiving Hoppers & $100 \mathrm{std}$. tons each \\
FD101A/B & Raw Coal Receiving Feeders & $1,125 \mathrm{std}$. tons $/ \mathrm{hr}$ each \\
CR102 & Raw Coal Transfer Conveyor & $2,250 \mathrm{std}$. tons $/ \mathrm{hr}$ \\
WS101 & Raw Coal Receiving Scale & $2,250 \mathrm{std}$ tons $/ \mathrm{hr}$ \\
F106 & Coal Receiving Dust Filter & $58,800 \mathrm{ACFM}$ \\
B105 & Coal Receiving Exhaust Fan & $58,800 \mathrm{ACFM}$ \\
CR111 & Filter Discharge Conveyor & $4.3 \mathrm{std}$. tons $/ \mathrm{hr}$ \\
FD111 & Receiving Filter Airlock Feeder & $4.3 \mathrm{std}$. tons $/ \mathrm{hr}$ \\
PG103 & Sampling System consisting of: & $2,250 \mathrm{std}$. tons $/ \mathrm{hr}$ \\
& CR116 Sample Rejects Bucket Elevator \\
& FD116 Primary Sample Feeder & \\
& FD118 Secondary Sample Feeder & \\
& SR103 Primary Sample Crusher & \\
& SS103 Primary Sampler & \\
& SS104 Secondary Sampler
\end{tabular}




\section{*Actual Cubic Feet per Minute}

The coal will be stored in a $250^{\prime}$ diameter field erected storage dome which will be sized to store 16,400 std. tons of coal, or approximately a twenty day supply. No exposed storage of coal, such as a coal pile, is planned, thus all coal storage will be within the dome. The material in the coal storage dome will be stockpiled and reclaimed by an automated circular coal pile stacker/reclaimer assembly. The raw coal will be discharged through a vibratory feeder onto the raw coal collecting conveyor. This conveyor will transfer the coal to the crushing station for sizing and screening. In the event of an emergency, provisions will be made to discharge the stockpile through an emergency reclaim hopper equipped with a feeder into the raw coal collecting conveyor. The coal storage system will consist of the following major components:

\begin{tabular}{lll} 
Item No. & Description & Duty \\
\hline X100 & Coal Storage Dome & $16,400 \mathrm{std}$. tons \\
CR105 & Raw Coal Collecting Conveyor & $340 \mathrm{std}$. tons $/ \mathrm{hr}$ \\
SE101 & Raw Coal Magnetic Separator & $340 \mathrm{std}$. tons $/ \mathrm{hr}$ design \\
F107A/B/C & Raw Coal Storage Dust Filters & $2,500 \mathrm{ACFM}$ (each) \\
B106A/B/C & Raw Coal Storage Exhaust Fans & $2,500 \mathrm{ACFM}$ (each) \\
PG102 & Stacker Reclaimer Package consisting of: & \\
& CR118 Stacking Conveyor & $2,250 \mathrm{std}$. tons $/ \mathrm{hr}$ \\
& RL101 Coal Pile Reclaimer & $110 \mathrm{std}$. tons $/ \mathrm{hr}$ normal \\
FD114A/B & Coal Pile Discharge Feeders & $340 \mathrm{std}$. tons $/ \mathrm{hr}$ max. \\
BN108 & Emergency Reclaim Hopper & $110 \mathrm{std}$ tons $/ \mathrm{hr}$ normal \\
P103A/B & Reclaim Tunnel Sump Pump & $340 \mathrm{std}$. tons $/ \mathrm{hr}$ max. \\
\end{tabular}

\subsubsection{Coal Crushing and Screening}

In coal crushing and screening, the raw coal will pass through a magnetic separator to remove tramp iron and will then be screened through a dual deck vibrating screen, which will control the product gasifier feed size of $1 / 4$ " $x 0$ through the $1 / 4$ " square holes of the lower deck of the vibrating screen. The oversize material from the upper deck will be fed to the coal crusher to bring the material size from $2^{\prime \prime} \times 0$ to the required $1 / 4 " \times 0$. This sized product will be recycled to the dual deck coal screen through flexible wall elevating conveyors. The $1 / 4 " \times 0$ product-size material will be transported into the coal storage silo utilizing an elevating flexible wall conveyor. The coal silo will be sized for 24-hour feed to the gasifier and will be filled daily through an 8-hour period operation of the crusher and the elevating conveyor.

A common single gasifier feed elevating conveying equipment system will be provided from the coal and/or start-up coke and the limestone silos to the gasifier area. The conveying system will consist of a weigh belt feeder from each silo and the common elevating conveyor. The system will be operating continuously during feeding of the gasifier. As with the raw coal handling system, care will be taken to 
control any dust emission sources by means of dust collection system. The coal crushing and screening system will consist of the following major components:

\begin{tabular}{lll} 
Item No. & Description & \multicolumn{1}{c}{ Duty } \\
B111 & Crushing Station Dust Filter Fan & $19,750 \mathrm{ACFM}$ \\
FD115 & Crushing Station Dust Filter Feeder & $2.0 \mathrm{std}$. tons $/ \mathrm{hr}$ \\
CR114 & Oversize Coal Elevator & $125 \mathrm{std}$. tons $/ \mathrm{hr}$ \\
CR115 & Sized Coal Conveyor & $50 \mathrm{std}$. tons $/ \mathrm{hr}$ \\
F109 & Crushing Station Dust Filter & $19,750 \mathrm{ACFM}$ \\
SE104 & Coal Screen & $235 \mathrm{std}$. tons $/ \mathrm{hr}$ \\
SR102 & Coal Crusher & $125 \mathrm{std}$. tons $/ \mathrm{hr}$ \\
FD117 & Oversize Coal Feeder & $125 \mathrm{std}$. tons $/ \mathrm{hr}$ \\
BN109 & Emergency Surge Hopper & $20 \mathrm{std}$. tons $/ \mathrm{hr}$ \\
CR117 & Emergency By-pass Conveyor & $340 \mathrm{std}$. tons $/ \mathrm{hr}$ \\
DV105 & Coal Dust By-pass Diverter & $340 \mathrm{std}$. tons $/ \mathrm{hr}$ \\
DV106 & Coal Dust By-pass Diverter & $2.0 \mathrm{std}$. tons $/ \mathrm{hr}$
\end{tabular}

\subsubsection{Coal. Coke and Limestone Feeding}

Dried coke breeze, $1 / 4^{\prime \prime} \times 0$, will be received in the plant via trucks with pneumatic trailers for initial plant start-up and for each subsequent gasifier start-up. The sized coke will be transferred from the trucks pneumatically to an 800-ton capacity coke storage silo using the truck-trailer's own pneumatic blower. Exhaust air from the filling operation will be vented through a dust control filter installed atop the coke silo. The material from the coke silo will be conveyed to the gasifier utilizing the cormirion coal/coke/limestone elevating conveyor. The coke silo will be equipped with a constant speed weigh feeder provided with a feed depth regulating valve to feed the required coke to the common elevating conveyors.

Sized limestone will be received at the job site, on a daily basis, via trucks with pneumatic trailers. The sized limestone will be conveyed pneumatically to a 300 ton (5-day) capacity limestone storage silo using the truck trailer pneumatic blower. Exhaust air from this filling operation will be vented through a dust control filter installed atop the limestone silo. The material from the limestone silo will then be fed at a controlled rate by a variable speed weigh feeder and blended with the coal on the same elevating conveying line feeding the gasifier. Provisions will be included to transport limestone to the sulfator limestone feed hopper by pneumatic conveying. The material will be discharged from the limestone silo and distributed to the two conveying lines utilizing a bifurcated feed line. The pneumatic conveying line to the sulfator will be provided with the required conveying air blower and a stand-by air blower. The coal, coke and limestone feeding system will consist of the following major components:

\begin{tabular}{lll} 
Item No. & Description & \multicolumn{1}{c}{ Duty } \\
\hline BN105 & Sized Coal Silo & 818 std. tons \\
BV102 & Coal Silo Bin Discharger & $15-50$ std. tons/hr \\
FD106 & Coal Silo Discharge Feeder & $15-50$ std. tons $/ \mathrm{hr}$ \\
F102 & Coal Silo Exhaust Filter & $2,500 \mathrm{CFM}$
\end{tabular}




\begin{tabular}{|c|c|c|}
\hline F105 & Gasifier Feed Dust Filter & 3,700 ACFM \\
\hline B104 & Gasifier Feed Dust Collection Fan & 3,700 ACFM \\
\hline BN106 & Coke Silo & 800 std. tons \\
\hline BV103 & Coke Bin Discharger & $15-50$ std. tons $/ \mathrm{hr}$ \\
\hline FD107 & Coke Silo Discharge Feeder & $15-50$ std. tons $/ \mathrm{hr}$ \\
\hline F103 & Coke Silo Exhaust Filter & $1,250 \mathrm{CFM}^{*}$ \\
\hline BN107 & Limestone Silo & 300 std. tons \\
\hline BV104 & Limestone Bin Discharger & $1.5-5.0$ std. tons $/ \mathrm{hr}$ \\
\hline B112 & Coal Silo Fan & 2,500 ACFM \\
\hline F104 & Limestone Silo Exhaust Filter & 1,250 ACFM \\
\hline FD108 & Limestone Silo Discharge Feeder & $1.5-5.0 \mathrm{std}$. tons $/ \mathrm{hr}$ \\
\hline $\mathrm{B} 110 \mathrm{~A} / \mathrm{B}$ & Limestone Transport Blower & 4 std. tons $/ \mathrm{hr}$ \\
\hline CR110 & Gasifier Feed Elevating Conveyor & 50 std. tons $/ \mathrm{hr}$ \\
\hline SE102 & Gasifier Feed Magnetic Separator & 50 std. tons/hr \\
\hline WS102 & Truck Scale & 100 std. tons \\
\hline D104 & Limestone Transporter & 4 std. tons $/ \mathrm{hr}$ \\
\hline
\end{tabular}

${ }^{*}$ Cubic Feet per Minute

\subsubsection{Dust Collection System}

Dust collection systems will be provided in the plant for proper environmental control. Fabric filter collectors will be used to control fugitive dust emissions from the transport and transfer of coal, coke and limestone.

All material handling systems will be enclosed and supplied with dust collection systems for environmental control, with special attention being paid to dust generating areas mainly transfer points.

\subsubsection{Solid Waste Handling (Area 1100)}

Cooled solid waste consisting of ash, fines and sulfated limestone (LASH) from the sulfation unit will be conveyed continuously to the solid waste storage silo using a pneumatic conveying system. The air displaced from the silo will be vented through the bin filter, installed atop the solid waste silo.

The LASH in the silo will be loaded onto trucks during the day shift operation, 5 days per week. The silo will be equipped with a bin discharger, discharge valve and a telescopic loading chute with a bag filter and fan to minimize dusting during the truck loading operation. The LASH will be then hauled to the final disposal point. A local landfill has expressed interest in using the material as a cover, and other usages are being investigated.

The solid waste silo will be sized for three days of storage ( 400 tons) to handle the solid waste production over the weekend without the need of the truck load-out operation. The solid waste handling system will consist of the following major components: 
Item No.

BN1101

BV1101

PG1101
Description

Solid Waste Bin

Solid Waste Discharger

Sold Waste Load-Out package consisting of:-

B1102 Load-Out Exhaust Fan

CH1101 Solid Waste Loading Chute

F1102 Solid Waste Load-Out Filter

XV1101 Cut-off Gate

B1103A/B Pneumatic Transport Blowers

D1101 Solid Waste Transporter

D1102 Ash Transporter

F1101 Silo Vent Filter
Duty

400 std. tons

100 std. tons $/ \mathrm{hr}$
1,000 SCFM* $^{*}$

100 std. tons $/ \mathrm{hr}$

1,000 SCFM* $^{*}$

$100 \mathrm{std}$. tons $/ \mathrm{hr}$

5 std. tons $/ \mathrm{hr}$

$7,000 \mathrm{lbs} / \mathrm{hr}$

$3,000 \mathrm{lbs} / \mathrm{hr}$

2,500 CFM

*Standard Cubic Feet per Minute

\subsubsection{Balance of Plant (Area 1200)}

\subsubsection{Raw Water System}

The raw water system will provide water to the demineralization package, PG1201, which in turn will provide BFW makeup to the deaerator, DH801. Additionally the raw water system will provide water for the plant utility water system for miscellaneous users such as service wash stations. Well water from Well No. 4 will be the source of water for the plant raw water system. Well water will be pumped to the existing Unit 3 raw water tank and then pumped by the raw vater pumps, P1202A/B, to the plant raw water system. Pumps P1202A/B will be designed to draw water from either the existing tank or directly fromWell No. 4.

Potable water for safety showers and eyewashes will be provided by the existing plant system. Drinking water will be provided as a brought-in bottled source.

\subsubsection{Boiler Feedwater Supply and Storage}

Makeup BFW will be demineralized by a package, PG1201, consisting of cation, degasification, anion and mixed bed units. Additionally, there will be storage and feeding of regenerating caustic and sulfuric acid, and appropriate local controls, including neutralization controls. Spare acid and caustic pumps and the neutralization air mixing system will also be included.

Regeneration waste will be stored in a neutralization tank, TK1202, where the waste will be mixed and neutralized before being sent to the dirty water sewer. Acid and caustic pumps will be provided for neutralization.

Demineralized water will be stored in TK1201 and pumped to the condensate system by the demineralized water pumps, $\mathrm{P} 1208 \mathrm{~A} / \mathrm{B} / \mathrm{C}$. 
This system will produce demineralized water from raw well water for BFW make-up at a rate of 280 GPM. The demineralization system will consist of the following major components:

\begin{tabular}{ll} 
Item No. & Description \\
\hline D1203A/B & Cation Units \\
T1201 & Degasifier \\
D1204A/B & Anion Units \\
D1211A/B & Mixed Bed Units \\
P1203A/B & Acid Regeneration Pumps \\
P1204A/B & Caustic Regeneration Pumps \\
P1205A/B & Acid Neutralization Pumps \\
P1206A/B & Caustic Neutralization Pumps \\
P1217A/B & Booster Pumps \\
B1202A/B & Degasifier Blowers \\
E1201 & Caustic Water Heater \\
D1201 & Acid Storage Drum (8' - 0" dia. x 10' - 0" T-T) \\
D1202 & Caustic Storage Drum (8' - 0" dia. x 13' - 0" T-T) \\
TK1201 & Demineralized Water Tank (12' - 0" dia. x 32' - 0" high) \\
P1208A-C & Demineralized Water Pumps \\
TK1202 & Neutralization Tank (12' - 0" dia. x 32' - 0' high)
\end{tabular}

\subsubsection{Boiler Water Treatment System}

A package of chemical dosing equipment will be provided for the conditioning of the boiler water. The boiler water treatment system will consist of the following major components:

$\begin{array}{ll}\text { Item No. } & \text { Description } \\ \text { TK1203 } & \text { Phosphate Tank } \\ \text { M1201 } & \text { Phosphate Mixer } \\ \text { P1211A/B } & \text { H.P. Phosphate Pumps } \\ \text { P1211C } & \text { Spare Phosphate Pump } \\ \text { P1212A/B } & \text { L.P. Phosphate Pumps } \\ \text { P1210A/B } & \text { Oxygen Scavenging Pump } \\ \text { P1213A/B } & \text { Amine Pump }\end{array}$

\subsubsection{Cooling Water System}

The cooling pond will provide makeup water for the cooling tower, CT1201. Pond water will be pumped from the existing pond water pump structure to the cooling tower basin by the make-up pump, P1201.

A conventional induced-draft 3-cell counter-flow cooling tower, CT1201, will be used for the plant cooling water system. The top of the basin is $3^{\prime}-6^{\prime}$ above grade. Cooling water will be circulated 
through cells 1 and 2 by the vertical turbine cooling water pumps, P1211 A/B/C, and through cell 3 by pumps P1220A/B through the use of a split basin. (See Waste Water System Section 1000.)

The cooling tower will be designed for the $2 \frac{1}{2} \%$ occurrence condition of a $61^{\circ} \mathrm{F}$ wet bulb temperature and provide $80.5^{\circ} \mathrm{F}$ cooling water at that condition. Blowdown from cell 3 will be sent to the waste water treatment system.

Biocide injection will be provided by a biocide feeder. Other additives, corrosion inhibitors, $\mathrm{pH}$ controlling, biocides, and scale/deposit inhibitors, will be injected into the cooling water by the water treatment injection system. The cooling water system will consist of the following major components:

\begin{tabular}{ll} 
Item No. & Description \\
\hline CT1201 & Cooling Tower \\
P1209A-C & Cooling Water Pumps (cells 1 \& 2) \\
D1208 & Inhibitor Tank \\
D1209 & Acid Tank \\
P1214A/B & Inhibitor Pumps \\
P1215A/B & Acid Pumps \\
FD1201 & Biocide Feeder \\
P1220A/B & Circulating Water Pumps (cell 3)
\end{tabular}

\subsubsection{Instrument and Plant Air System}

A conventional plant and instrument air compression system will be provided. Two air compressors, one operating, one spare, will be provided for the system. A single air receiver will provide adequate surge capacity. The air will be dried to a $-40^{\circ} \mathrm{F}$ dewpoint using an air drying desiccant system prior to branching off to plant and instrument air headers.

The following equipment will be provided to supply both Instrument and Plant Air:

\begin{tabular}{ll} 
Item No. & Description \\
\hline C1201A/B & Compressors \\
D1207 & Air Receiver \\
DR1201A/B & Air Dryers
\end{tabular}

\subsubsection{Flare System}

A flare system will be provided to incinerate the full product gas flow from the gasifier in the event of a power plant outage, gasifier start-up, or other emergencies. The flare, FL1201, will be a vertical freestanding system. Pilots will be designed to use natural gas or propane.

A $48^{\prime \prime}$ dia. $\times 60^{\prime}-0^{\prime \prime}$ flare stack with a capacity of $290,498 \mathrm{lbs} / \mathrm{hr}$ will be provided. 


\subsubsection{Nitrogen System}

Nitrogen will be required for maintaining a constant flow of purge gas through selected equipment and instruments, blow-back cleaning of the hot gas filter (when normal process gas is unavailable), pneumatic conveying of coal dust and system purging at shutdown.

The Nitrogen Package, PG1205, will be a cryogenic air separation plant wherein the constituents of air will be separated by cryogenic distillation delivering high purity nitrogen $(99.7 \%)$ in the required quantity.

Components of the package will include compressors, storage tanks, a liquid nitrogen pump and vaporizers sized to provide for start-up, normal operation and a safe shutdown of the facility.

\subsubsection{Propane System}

Propane will be the tertiary fuel to the combustion gas turbine. Liquid propane will be delivered by tank truck or tank car and stored in two 100,000 gallon (nominal) storage drums. The drums will be oriented, and earthen berms constructed, to minimize damage in the event of tank failure. Storage will be in accordance with the applicable National Fire Prevention Association (NFPA) requirements. When required, liquid propane will be drawn off the storage drums and pumped to the vaporizer prior to combustion as fuel in the combustion gas turbine. The propane system will consist of the following major components:

Item No. Description

D1205 Propane Storage Drum

D1206 Propane Storage Drum

P1216A/B Vaporizer Feed Pumps

E1202 Vaporizer

\subsubsection{Waste Water Treatment (Area 1000)}

Wastewater from the demineralization system and the blowdown from cells 1 and 2 of the cooling tower will be sent to the wastewater treatment system.

This system will soften and clarify these wastes and forward the treated water to the cooling tower cell 3 as make-up.

The sludge generated in the clarifier will be thickened and dewatered. The supernatant (surface) water from these processes is recycled within the waste treatment system.

Blowdown from cell 3 of the cooling tower will be discharged to an evaporation pond. 
The pond will be double lined, and the system will be designed to meet the requirements of the Nevada Division of Environmental Protection (NDEP). The pond surface area (approx. 4 acres) is minimized by the use of eleven (11) floating water spray units, SX1001A-K. These will be located across the pond surface, each equipped with its own electric drive system. Water will be pumped up through each unit and sprayed across the pond surface improving the evaporation rate. The wastewater will not pose any adverse effect on wildlife such as migrating water fowl. Monofilament line with 25 ' spacing, which is unobtrusive to the human observer, has been used by SPPCo to successfully discourage migrating water fowl from landing in several of SPPCo's facilities.

The system will consist of the following items:

$\begin{array}{ll}\text { Item No. } & \text { Description } \\ \text { CL1001 } & \text { Reactor Clarifier } \\ \text { CL1002 } & \text { Thickener } \\ \text { D1001 } & \text { Caustic Drum } \\ \text { F1001 } & \text { Plate Filter Press } \\ \text { FR1001 } & \text { Soda Ash Feeder } \\ \text { P1001A/B } & \text { Dirty Waste Water Pumps } \\ \text { P1002A/B } & \text { Clean Waste Water Pumps } \\ \text { P1003A/B } & \text { Clarifier Effluent Pumps } \\ \text { P1004A/B } & \text { Clarifier Blowdown Pumps } \\ \text { P1005A/B } & \text { Sludge Sump Pumps } \\ \text { P1006A/B } & \text { Thickener Sludge Pumps } \\ \text { P1007A/B } & \text { Caustic Pumps } \\ \text { P1008A/B } & \text { Soda Ash Pumps } \\ \text { P1009A/B } & \text { Magnesium Chloride Pumps } \\ \text { SX1000A-K } & \text { Spray Modules } \\ \text { TK1001 } & \text { Clarifier Effluent Aging Tank } \\ \text { TK1002 } & \text { Magnesium Chloride Tank } \\ \text { TK1003 } & \text { Soda Ash Tank }\end{array}$

\subsection{Electrical Distribution}

The existing Tracy sub-station is supplied at $120 \mathrm{KV}$ by SPPCo. Connection to this system will be through tie and service breakers feeding unit transformers connected to the gas and steam turbrbine generators. The generators will be rated at $13.8 \mathrm{KV}$ with maximum generator output equal to elevated temperature and/or auxiliary cooling transformer rating as required. The auxiliary power will be fed from each generator transformer servicing large motors $250 \mathrm{hp}$ and over at $4.16 \mathrm{KV}$ and $480 \mathrm{~V}$ for general distribution. The $4.16 \mathrm{KV}$ and $480 \mathrm{~V}$ will be distributed radially. A second feeder from an existing $4.16 \mathrm{KV}$ transformer will permit alternate service in the event of maintenance turnarounds or equipment outages. However, this transformer will not be able to carry the coal gasification process in addition to the generator auxiliaries. 
Metering will be on the $120 \mathrm{KV}$ system for assessment. Additional metering will be furnished for gasifier, steam plant, material handling and auxiliary services. Protection will be arranged as required to coordinate with the SPPCo system and internal users.

Auxiliary systems within the plant will be serviced by Uninterruptible Power Supply (UPS) or batteries to support personnel safety and critical equipment during shutdowns or power outages.

\subsection{Instrumentation}

\subsubsection{Digital Control System (DCS)}

Plant process and supervisory control shall be performed with a DCS "Process Manager" type redundant processor located in the main control building. DCS Input/Output (I/O) cabinetry will be mounted close to the entry point of the field wiring into the control room. The cabinetry will contain the I/O terminals, I/O processing equipment, the controller files for the DCS, and all interconnecting vendor prefabricated cables. Redundant DCS network cables interconnecting the equipment mounted in the I/O cabinetry and the DCS operator's consoles will be vendor prefabricated "coax" cables. Gasifier island signals will be interfaced with the DCS operators console via a remote I/O unit located in the Gasifier Remote Instrument Enclosure (RIE) (see Section 3.5.5). The DCS will comprise equipment, hardware, and software of one single manufacturer, and be "equal" in functionality, quality, and proven operability, to the TDC-3000 LCN, UCN, and Process Manager product line as manufactured by Honeywell, Inc., Phoenix Arizona.

\subsubsection{Continuous Emission Monitoring System (CEMS)}

Two (2) CEMS shall be provided for monitoring of $\mathrm{SO}_{2}, \mathrm{NOx}, \mathrm{O}_{2}$, opacity and flow. The systems shall be housed in an enclosure with Heating, Ventilation, Air Conditioning (HVAC) and sampling systems. A Data Acquisition System (DAS) shall be provided with the PC located in an analyzer house. The systems shall be certified by the system vendor's subcontractor to be in compliance with all federal and state requirements.

\subsubsection{Water Analysis}

A panel shall be provided with analyzers to analyze/monitor the following water constituents:
a. Dissolved Oxygen (DO) - qty (2)
b. Oxygen Scavenger - qty (1)
c. Sodium - qty (2)
d. Ammonia - qty (2)
e. $\mathrm{pH}$ - qty (4)
f. Silicates $\left(\mathrm{S}_{1} \mathrm{O}_{2}\right)$ - qty (2)
g. Conductivity - qty (4)
h. Hydrogen - qty (1) 
The above analyzers shall be mounted in a "dry" section of the panel. A "wet" section shall be provided for the sample conditioning systems, sink, etc.

\subsection{Fire Protection System}

Current plant fire protection for the steam plant area will be, as a minimum, per NFPA 850, "Fire Protection for Electric Generating Plants".

Fire water supply shall be from the existing plant underground loop system. $10^{\prime \prime}$ dia. undergroung (U/G) piping from the existing plant loop system shall be extended throughout for service to new equipment areas including the gasifier island.

Sprinkler systems (dry pipe or deluge) shall be provided as required for the following areas:

- $\quad$ steam turbine generator/utility building

- $\quad$ administration building

- maintenance building

- $\quad$ yard piping including fire hydrants, hose stations and post indicator valves (P.I.V.'s)

- $\quad$ propane system

- coal handling and storage systems

$\mathrm{A} \mathrm{CO}_{2}$ System shall be provided for the control room expansion.

\section{$5.7 \quad$ Buildings}

The steam turbine generator along with its auxiliary components (surface condenser, condensate pumps, boiler feed water pumps, boiler feed water heaters, water treating facilities, compressor and deaerator) will be housed in one building. The gasifier will be supported in a steel structure but will not be enclosed. The gas turbine generator set and ancillary subsystems will have their own, vendor-provided enclosures.

Two pre-engineered buildings will be constructed to provide new maintenance/machine shop facilities and administration offices. A car port of $40^{\prime} \times 120^{\prime}$ will be built near the office and maintenance buildings.

The administration building will include the following:

- Reception Area

- Manager's Office and nine other single offices

- Lunch Room - 6-8 people seating

- Conference Room - 14 people

- Toilet Facilities for men and women and janitorial closet

- Locker and Shower Facility - 12 men and 8 women

- Utility Room 
- $\quad$ Files/Prints/Storage Room

- Visitor Center - 30 people

- HVAC Facility for entire office building

Above will be a pre-engineered $50^{\prime} \times 100^{\prime}$ building with finish appearance of office building, gypsum board partition walls and acoustical tile ceiling.

The maintenance building will include the following:

- Maintenance Supervisor's Office

- Tool Storage

- Welding Area/Lathe Benches

- Laydown Area

- Machinist's Work Area/Repair Shop

- Lunch Room - 10 people seating

- Toilet Facilities for men and women and janitorial closet

- Locker and Shower Facility - 24 men and 6 women

Above will be a pre-engineered $50^{\prime} \times 100^{\prime} \times 14^{\prime}$ high building with insulated siding provided with louvers and exhaust fans (roof), roll-up door 10' wide $x$ 12' high at each end, and 2 ton monorail.

All other equipment will be located outside without enclosures. Outside, small rotating equipment items will be provided as totally enclosed fan cooled or with equivalent protection.

The existing Unit 3 control room will be expanded to accommodate the Piñon Pine Project needs. Heated enclosures and/or heat tracing shall be provided for steam drum level controls, and any other system where freezing conditions may cause service interruptions.

\subsection{Access Roads/Storm Water Treatment}

\subsubsection{Drainage and Erosion Control}

Storm water control will be based on zero discharge. A number of small retention basins will be created during the initial stage of construction. All storm water during construction as well as during normal plant operation will be drained to the nearest basin.

Since the plant site receives very little precipitation, all of it will ultimately evaporate or be absorbed in the ground, and there will be no run-off.

\subsubsection{Area Surfacing and Roads}

Roads around combined-cycle area will be asphalt paved. Roads in material handling and out laying areas will be gravel or crushed stone finish. Also, all areas around major equipment foundations, cooling tower, stack and electrical substations will be gravel finish. 
Heavy embankments or deep cuts along the railroad spur and other places will receive riprap to protect the soil from erosion.

\subsection{ESTIMATED PLANT PERFORMANCE}

The following table shows the approximate plant performance at the plant average ambient condition of $50^{\circ} \mathrm{F}, 20 \% \mathrm{RH}$.

\begin{tabular}{|l|l|}
\hline \multicolumn{2}{|c|}{ PIN̄ON PINE POWER PROJECT } \\
ESTIMATED PLANT PERFORMANCE \\
\hline \multicolumn{1}{|c|}{ IGCC Item \& Units* } & Quantity \\
\hline Coal Feed (TPD)* & 880.6 \\
\hline Gas Turbine Power (MWe) & 60.99 \\
\hline Steam Turbine Power (MWe) & 46.23 \\
\hline Gross Power (MWe) & 107.22 \\
\hline Auxiliary Power (MWe) & 7.51 \\
\hline Net Power (MWe) & 99.71 \\
\hline Net Heat Rate (Btu(LHV)/kWh) & 8096 \\
\hline Net Heat Rate (Btu(HHV)/kWh) & 8390 \\
\hline Thermal Efficiency (LHV)\% & 42.1 \\
\hline Thermal Efficiency (HHV) \% & 40.6 \\
\hline
\end{tabular}

*Refer to Glossary 


\subsection{APPENDICES}

7.1 Equipment List - Revision 9 dated 9/29/94

7.2 Process Flow Diagrams (PFD's)

Drawing No. Description Rev.

4141-2-50-112 Oxidant Compression and Supply Coal Gasification 5

4141-2-50-113 Coal Gasification 5

4141-2-50-114 Gas Stream Heat Recovery, Gas Stream Particulate Removal and Recycle Gas Compression 5

4141-2-50-116 Gas Stream Particulate Removal 5

4141-2-50-117 Desulfurization and Waste Solids Treatment 5

4141-2-50-118 Transport Desulfurization 1

MWK J-7514 Gasifier Island Heat and Material Balance Base Case 3

4142-2-50-200 BFW/Steam/Condensate-Heat and Material Balance D

4142-2-50-201 BFW/Steam/Condensate-Heat and Material Balance D

4142-2-50-210 Gas Turbine Generator

4142-2-50-211 Heat Recovery Steam Generator D

4142-2-50-212 Steam Turbine Generator D

4142-2-50-213 Deaerator Heater \& Blowdown Drums D

4143-2-50-310 Solids Receiving, Storing \& Crushing H

4143-2-50-311 Wastewater Treatment C

4143-2-50-312 Solid Waste Handling System D

4143-2-50-313 Boiler Feedwater Treatment C

4143-2-50-314 Cooling Water System C

4143-2-50-315 River \& Raw Water Systems

4143-2-50-316 Boiler Water Treatment $\quad$ C

4143-2-50-317 Instrument \& Plant Air System C

4143-2-50-318 Flare System

4143-2-50-319 Propane System $\quad$ C 
7.3 Plot Plans

\begin{tabular}{llc} 
Drawing No. & Description & Rev \\
\hline $61-D 1$ & Gasifier Island - Overall & 3
\end{tabular}

61-D2 Gasifier Island - Plan at Grade 3

61-D3 Gasifier Island - Plan at El. 97'-0" to El. 117'-0" 3

61-D4 Gaisifer Island - Plan at El. 117-0" to El. 137'-0" 3

61-D5 . Gasifier Island - Plan at El. 137'-0" to El. 177'-0" 3

61-D6 Gasifier Island - Plan at El. 177'-0" and Above 3

61-D7 Gasifier Island - Plan South Elevation 3

61-D8 Gasifier Island - Plan Isometric View 3

61-D9 Gasifier Island - Plan West Elevation 3

4142-1-51-100 Site Key Plot Plan D

4142-1-51-101 Key Plot Plan - Gasification Island, Combined-Cycle

Power Island \& Offsites

D

4142-1-51-102 Key Plot Plan - Offsites D

4142-1-51-1 Steam Turbine at Grade C

4142-1-51-2 Steam Turbine at Upper Level C

4142-1-51-3 Gas Turbine C

4142-1-51-4 HRSG at Grade C

4142-1-51-5 HRSG at Upper Level C

4142-1-51-6 Section $800 / 1200 \quad$ C

4143-1-51-1 Section 100 and 1100 at Gräde C

4143-1-51-2 Section 100 and 1100 at Upper Level C

4143-1-51-3 Coal Storage Dome C

4143-1-51-4 Flare Stack C

4143-1-51-5 Gasification Area (Rack only) C

4143-1-51-6 Switchyard $\quad$ C

4143-1-51-7 Transfer Sump C

4143-1-51-8 Nitrogen Facility C

4143-1-51-9 Cooling Tower $\quad$ C

4143-1-51-10 Unloading Station C

7.4 Heat and Material Balances

LL1

TOPICALRPTAm 


\section{EQUIPMENT LIST}

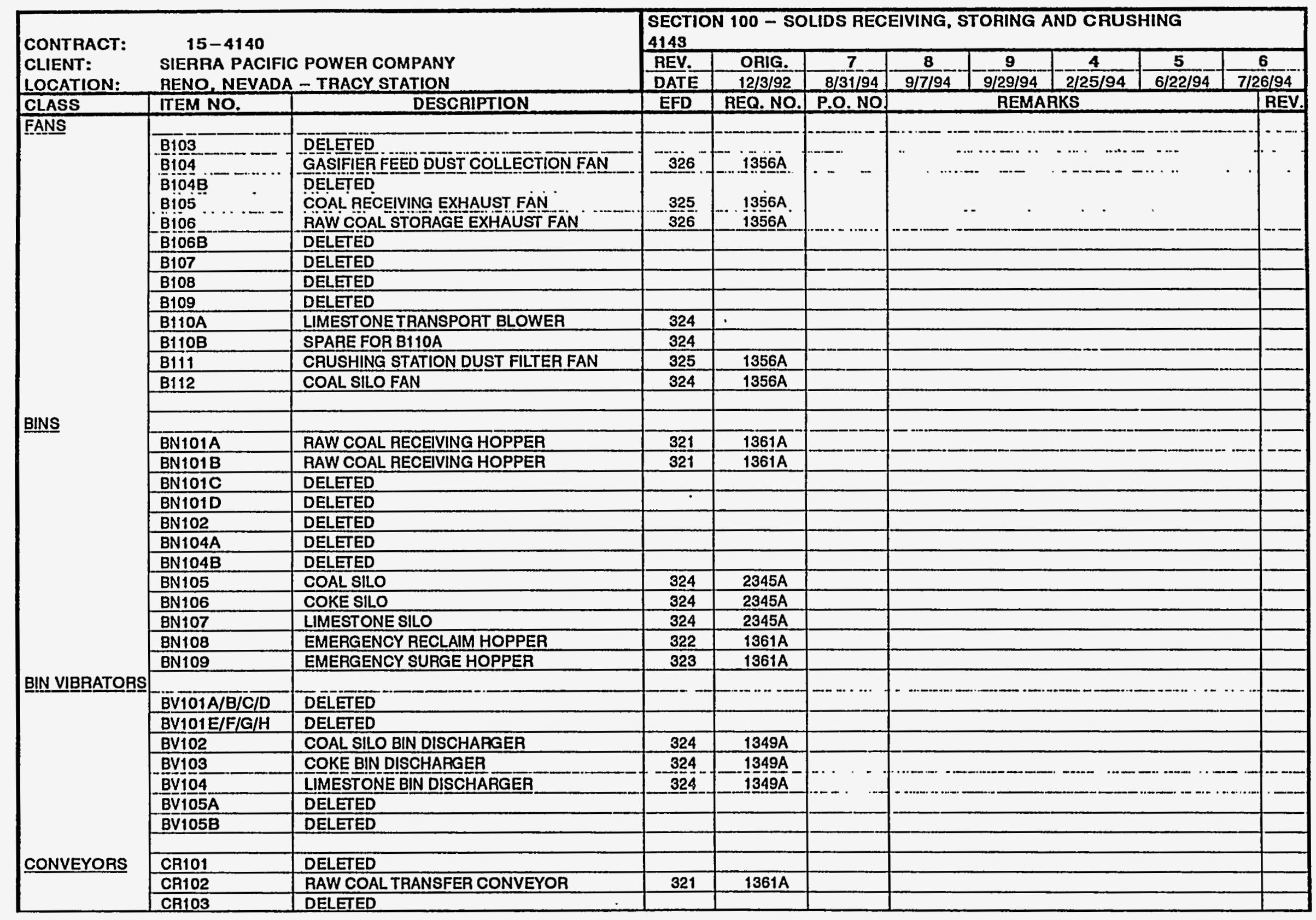




\section{EQUIPMENT LIST}

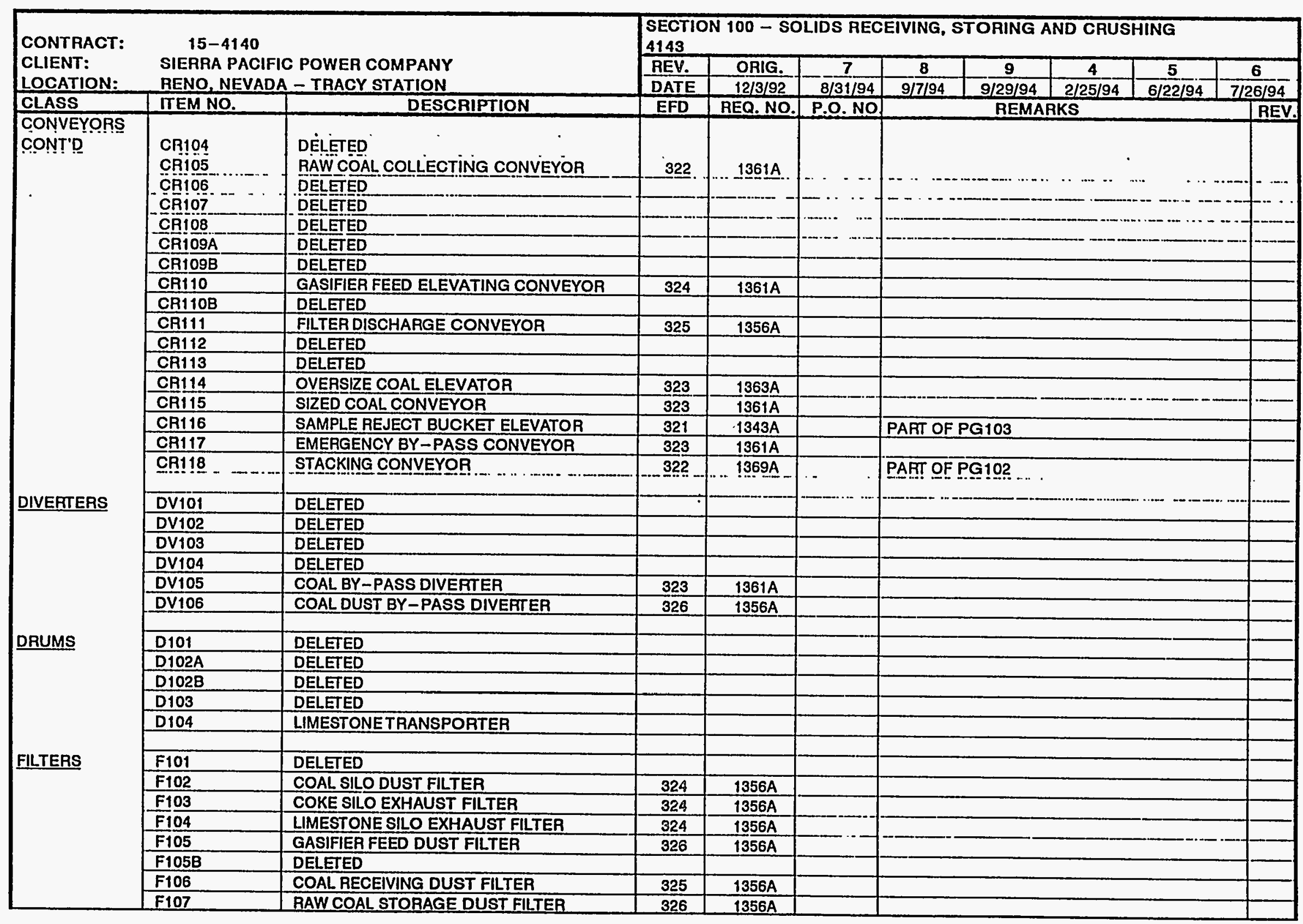




\section{EQUIPMENT LIST}

\begin{tabular}{|c|c|c|c|c|c|c|c|c|c|c|c|}
\hline \multirow{4}{*}{$\begin{array}{l}\text { CONTRACT: } \\
\text { CLIENT: } \\
\text { LOCATION: } \\
\text { CLASS }\end{array}$} & \multirow{3}{*}{\multicolumn{2}{|c|}{$\begin{array}{l}15-4140 \\
\text { SIERAA PACIFIC POWER COMPANY } \\
\text { RENO, NEVADA - TRACY STATION }\end{array}$}} & \multicolumn{9}{|c|}{$\begin{array}{l}\text { SECTION } 100 \text { - SOLIDS RECEIVING, STORING AND CRUSHING } \\
4143\end{array}$} \\
\hline & & & \multirow{2}{*}{ REV. } & \multirow{2}{*}{ OAIG. } & \multirow{2}{*}{$\frac{7}{8 / 31 / 94}$} & \multirow{2}{*}{$\frac{8}{9 / 7 / 94}$} & \multirow{2}{*}{$\frac{9}{9 / 29 / 94}$} & \multirow{2}{*}{$\frac{4}{2 / 25 / 94}$} & \multirow{2}{*}{$\frac{5}{6 / 22 / 94}$} & \multirow{2}{*}{\multicolumn{2}{|c|}{$7 / 26 / 94$}} \\
\hline & & & & & & & & & & & \\
\hline & ITEM NO. & DESCRIPTION & EFD & REQ. NO. & P.O. NO & & REMA & KS & & & \\
\hline \multicolumn{12}{|l|}{ FILTERS } \\
\hline \multirow[t]{3}{*}{ CONNI'D } & F108 & DELETED & & & & \multirow{2}{*}{\multicolumn{5}{|c|}{ 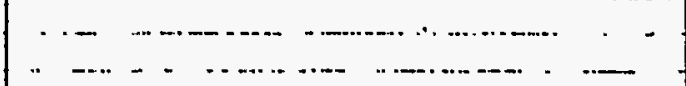 }} & \\
\hline & F109 & CRUSHING STATION DUST FILTER & 325. & $1356 \mathrm{~A}$ & & & & & & & \\
\hline & & & & & & & & & & & \\
\hline \multirow{27}{*}{ FEEEDERS } & & & & & & & & & & & \\
\hline & FD101A & RAW COAL RECEIVING FEEDER & 321 & $1361 \mathrm{~A}$ & & & & & & & \\
\hline & FD101B & RAW COAL RECEIVING FEEDER & 321 & $1361 \mathrm{~A}$ & & & & & & & \\
\hline & FD101C & DELETED & & & & & & & & & \\
\hline & FD1010 & DELETED & & & & & & & & & \\
\hline & $\mathrm{FD} 102 \mathrm{~A} / \mathrm{B} / \mathrm{C} / \mathrm{D}$ & DELETED & & & & & & & & & \\
\hline & FD102E/F/G/H & DELETED & & & \multirow{3}{*}{ 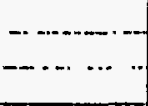 } & \multirow{2}{*}{\multicolumn{5}{|c|}{ - }} & \\
\hline & Fo1 & DELETED & & & & & & & & & \\
\hline & FD104 & DELETED & & & & \multicolumn{5}{|c|}{ - } & \\
\hline & FD105 & DELETED & & & & \multicolumn{5}{|c|}{ 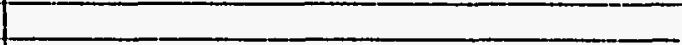 } & \\
\hline & FD106 & COAL SILO DISCHARGE FEEDER & 324 & $1342 \mathrm{~A}$ & & \multirow{2}{*}{\multicolumn{5}{|c|}{+2}} & \\
\hline & FD106B & DELETED & & & & & & & & & \\
\hline & FD107 & COKE SILO DISCHARGE FEEDER & 324 & $1342 \mathrm{~A}$ & & \multicolumn{5}{|c|}{ 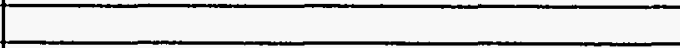 } & \\
\hline & FD108 & LIMESTONE SILO DISCHARGE FEEDER & 324 & $1342 \mathrm{~A}$ & & \multirow{2}{*}{\multicolumn{5}{|c|}{$+2+20$}} & \\
\hline & FD108B & DELETED & & & & & & & & & \\
\hline & FD109 & DUST FILTER FEEDER & 326 & $1356 \mathrm{~A}$ & & $\ldots$ & 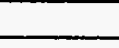 & _ & $\ldots$ & $\ldots$ & \\
\hline & FD111 & RECEIVING FILTER AIRLOCK FEEDER & 325 & $1356 \mathrm{~A}$ & & & & & & & \\
\hline & FD112 & AAW COAL STORAGE DUST FILTER FEEDER & 326 & $1356 \mathrm{~A}$ & & & & & & & \\
\hline & FD113 & DELETED & 324 & & & & & & & & \\
\hline & FD113B & DELETED & & & & & & & & & \\
\hline & FD114A & COAL PILE DISCHARGE FEEDER & 322 & 1361B & & & & & & & \\
\hline & FD114B & COAL PILE DISCHARGE FEEDER & 322 & $1361 \mathrm{~B}$ & & & & & & & \\
\hline & FD114C & DELETED & & & & & & & & & \\
\hline & FD115 & CRUSHING STATION DUST FILTER FEEDER & 325 & $1356 \mathrm{~A}$ & & & & & & & \\
\hline & FD116 & PRIMARY SAMPLE FEEDER & 321 & $1343 A$ & & PART O & G103 & & & & \\
\hline & FD117 & OVERSIZE COAL FEEDER & 323 & & & & & & & & \\
\hline & FD118 & SECONDARY SAMPLE FEEDER & 321 & $1343 \mathrm{~A}$ & & PART OI & G103 & & & & \\
\hline HEATERS & H101 & DELETED & & & & & & & & & \\
\hline & & & & & & & & & & & \\
\hline MISC. & $\mathrm{X} 100$ & COAL STORAGE DOME & 322 & $2499 A$ & & & & & & & \\
\hline & & & & & & & & & & & \\
\hline PACKAGES & PG101 & DELETED & & & & & & & & & \\
\hline & PG102 & STACKER - RECLAIMER PACKAGE & 322 & $1369 \mathrm{~A}$ & & & & & & & \\
\hline & PG103 & AAW COAL SAMPLING PACKAGE & 321 & & & & & & & & \\
\hline
\end{tabular}




\section{EQUIPMENT LIST}

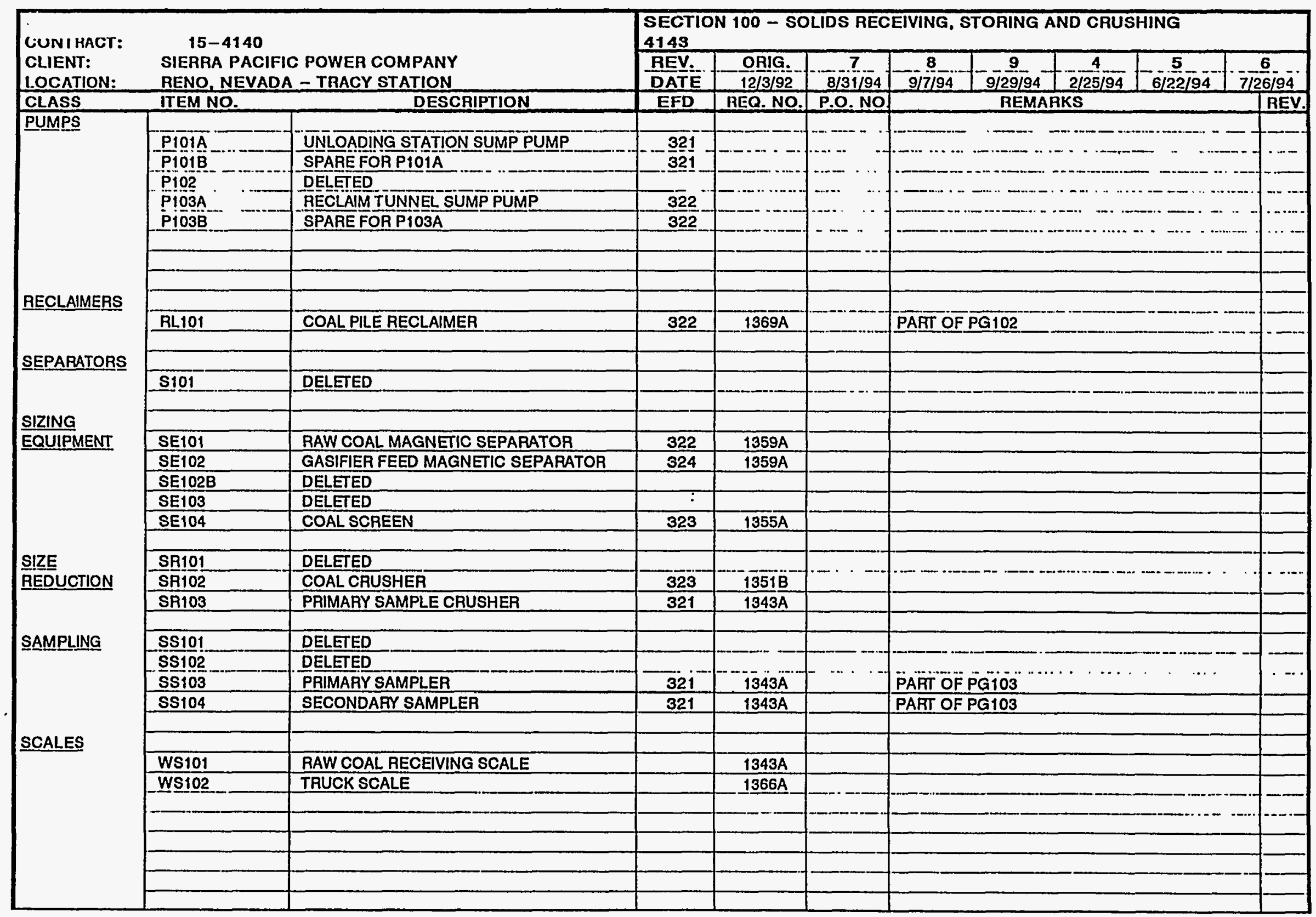




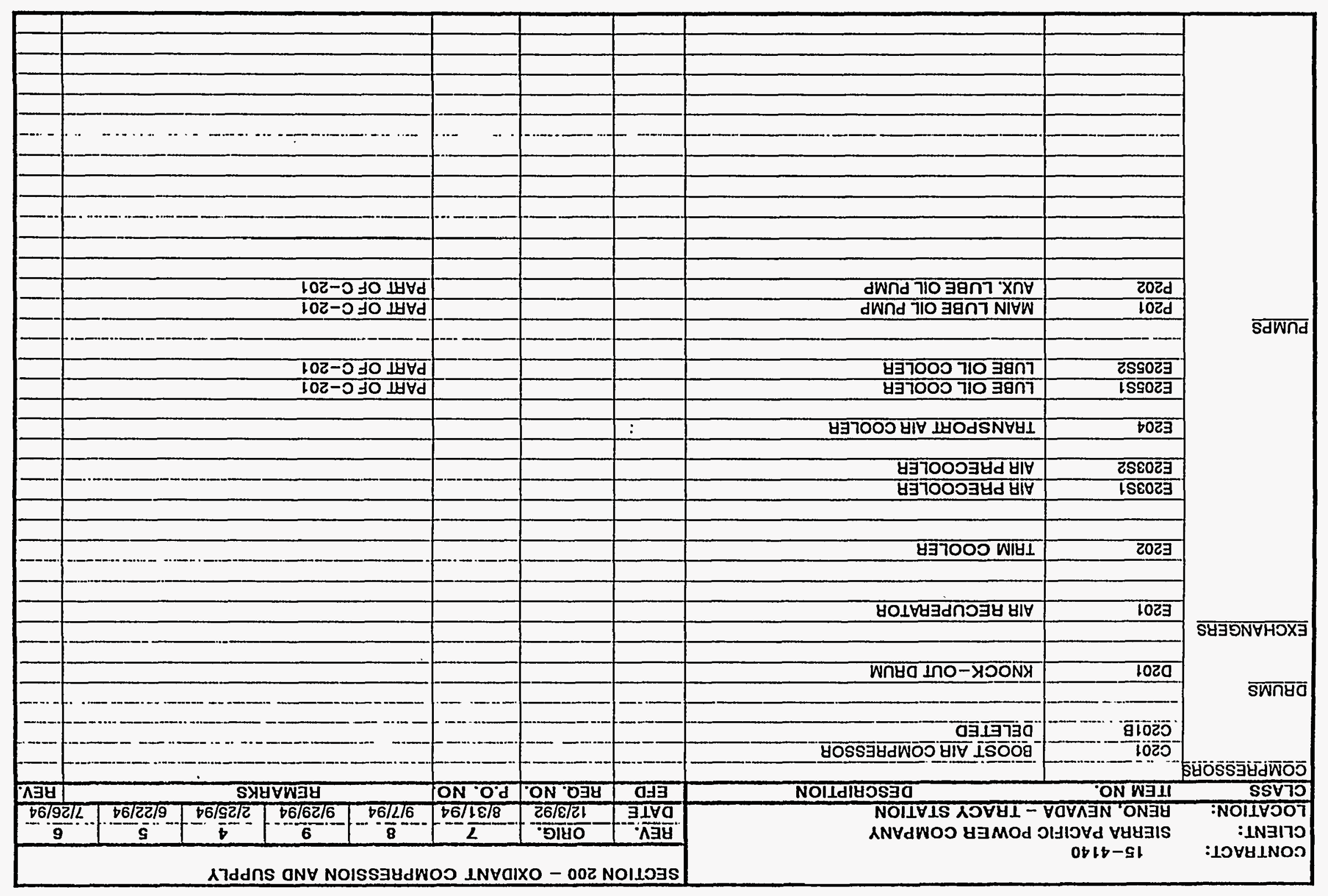

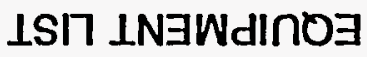




\section{EQUIPMENT LIST}

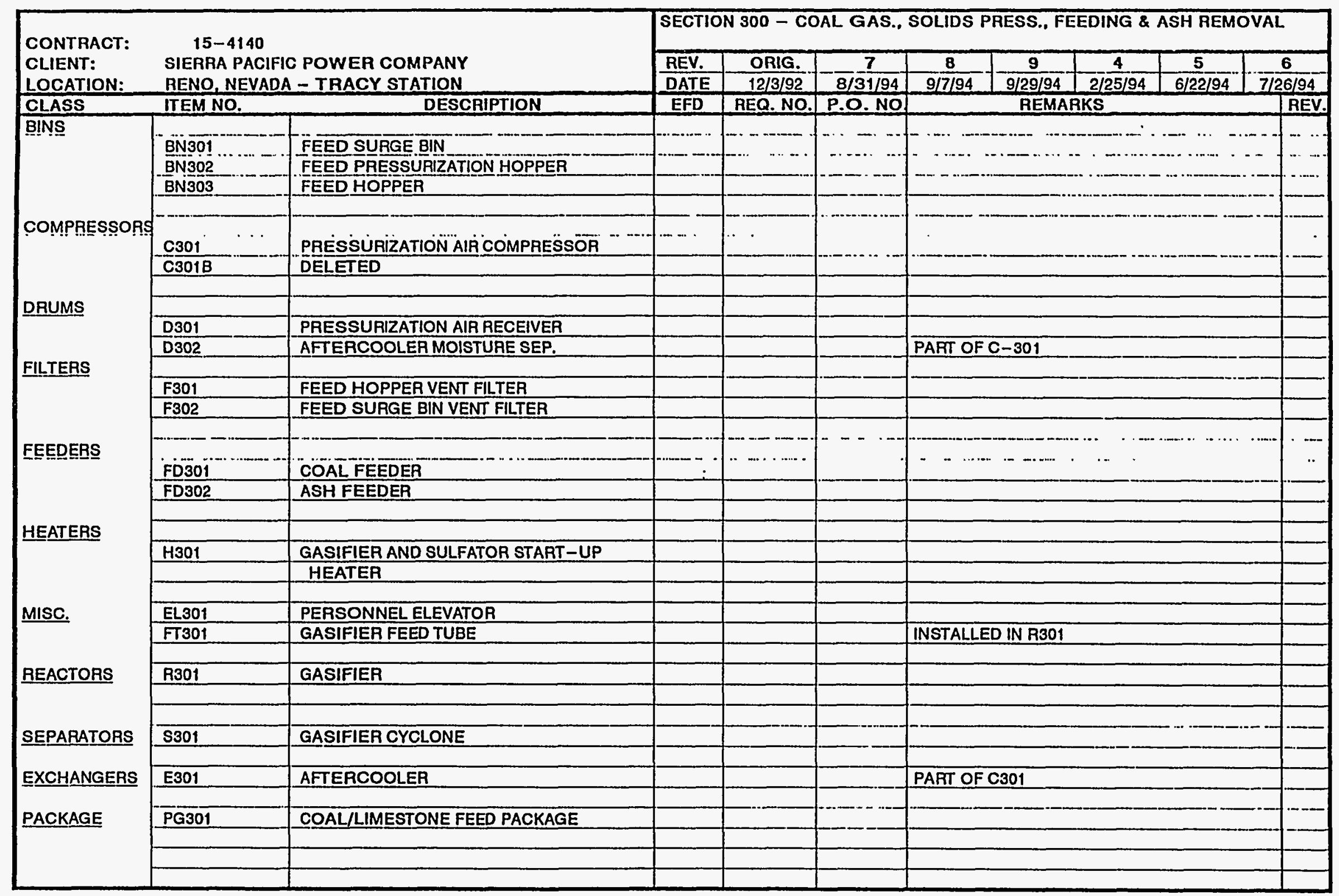


EQUIPMENT LIST

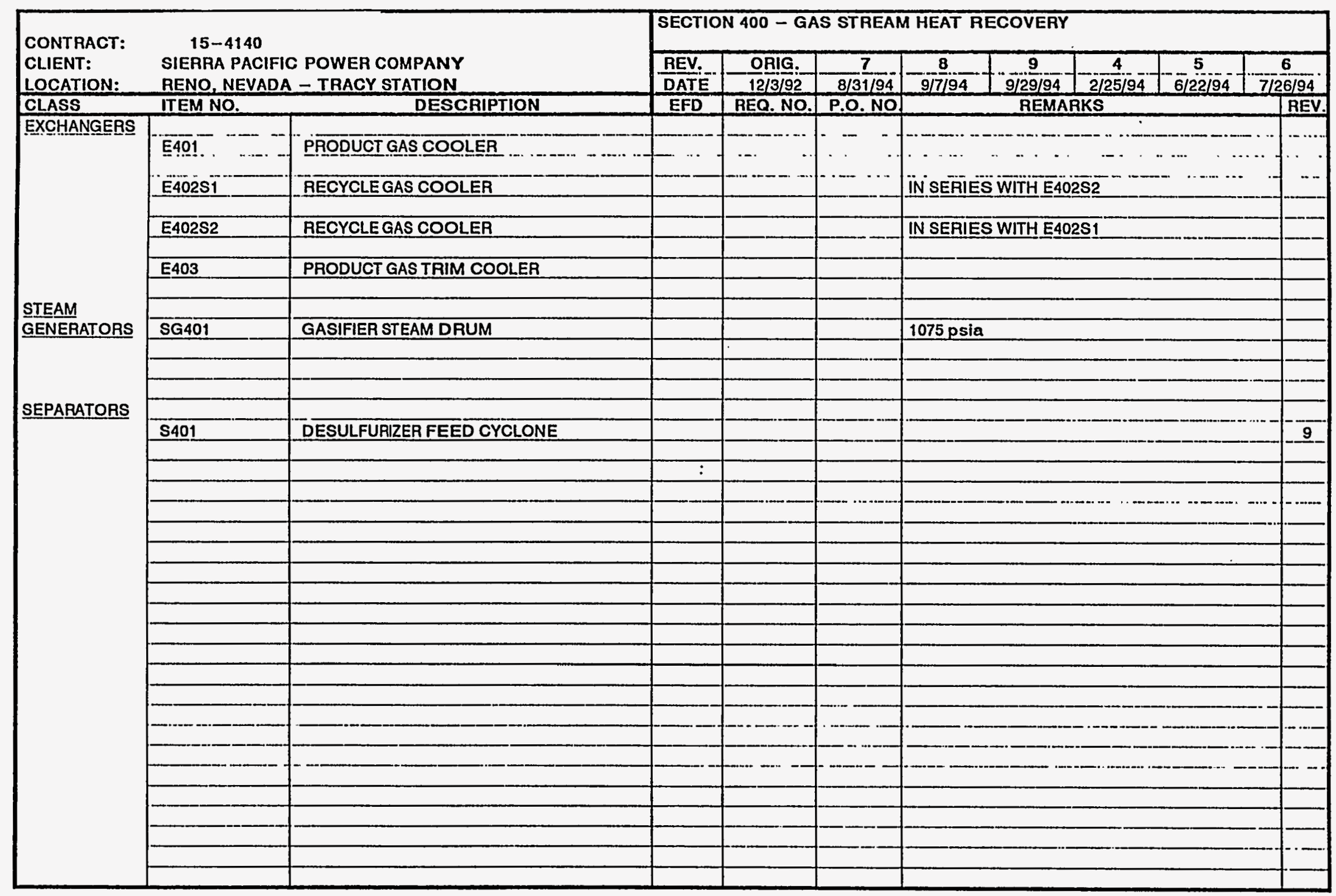




\section{EQUIPMENT LIST}

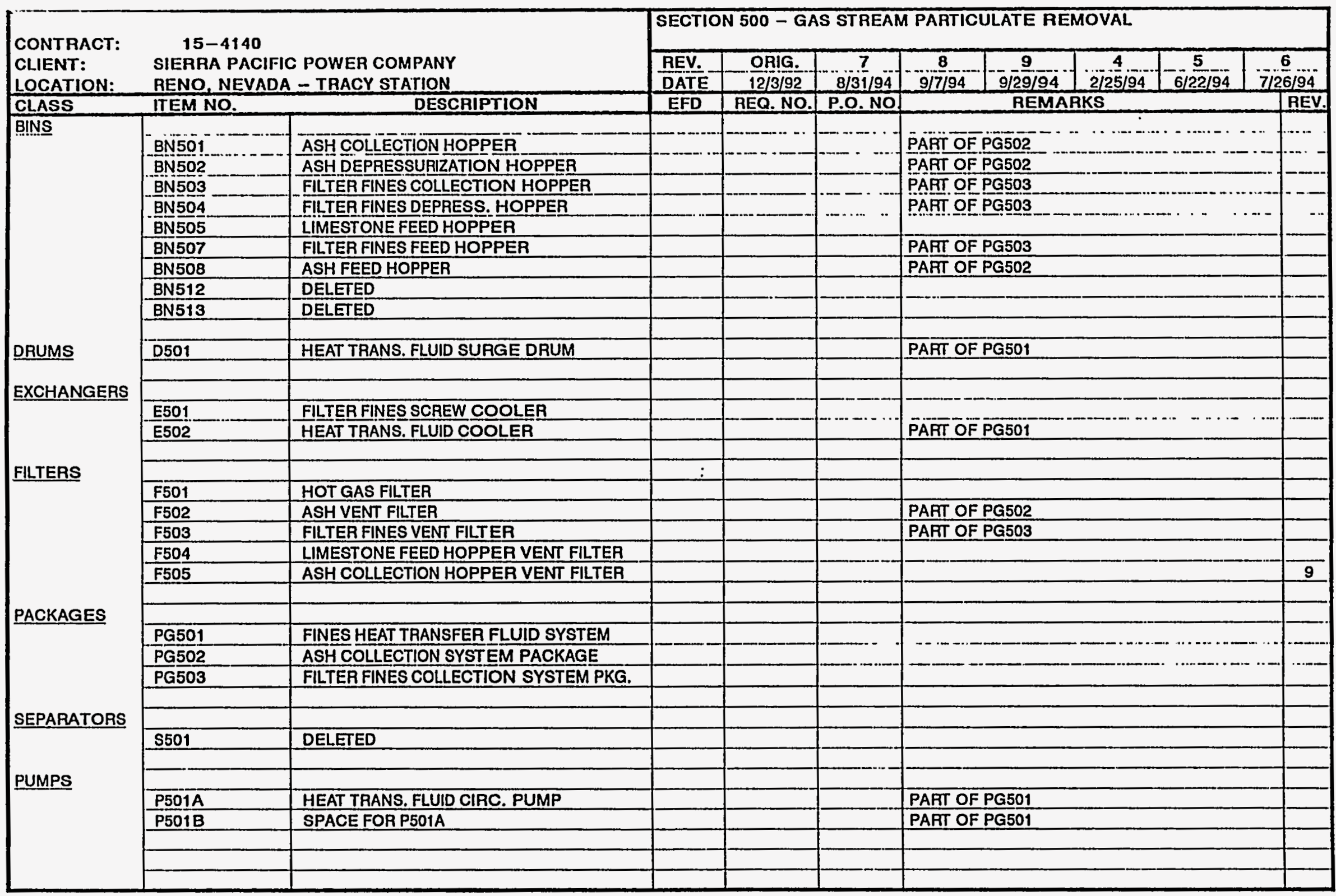




\section{EQUIPMENT LIST}

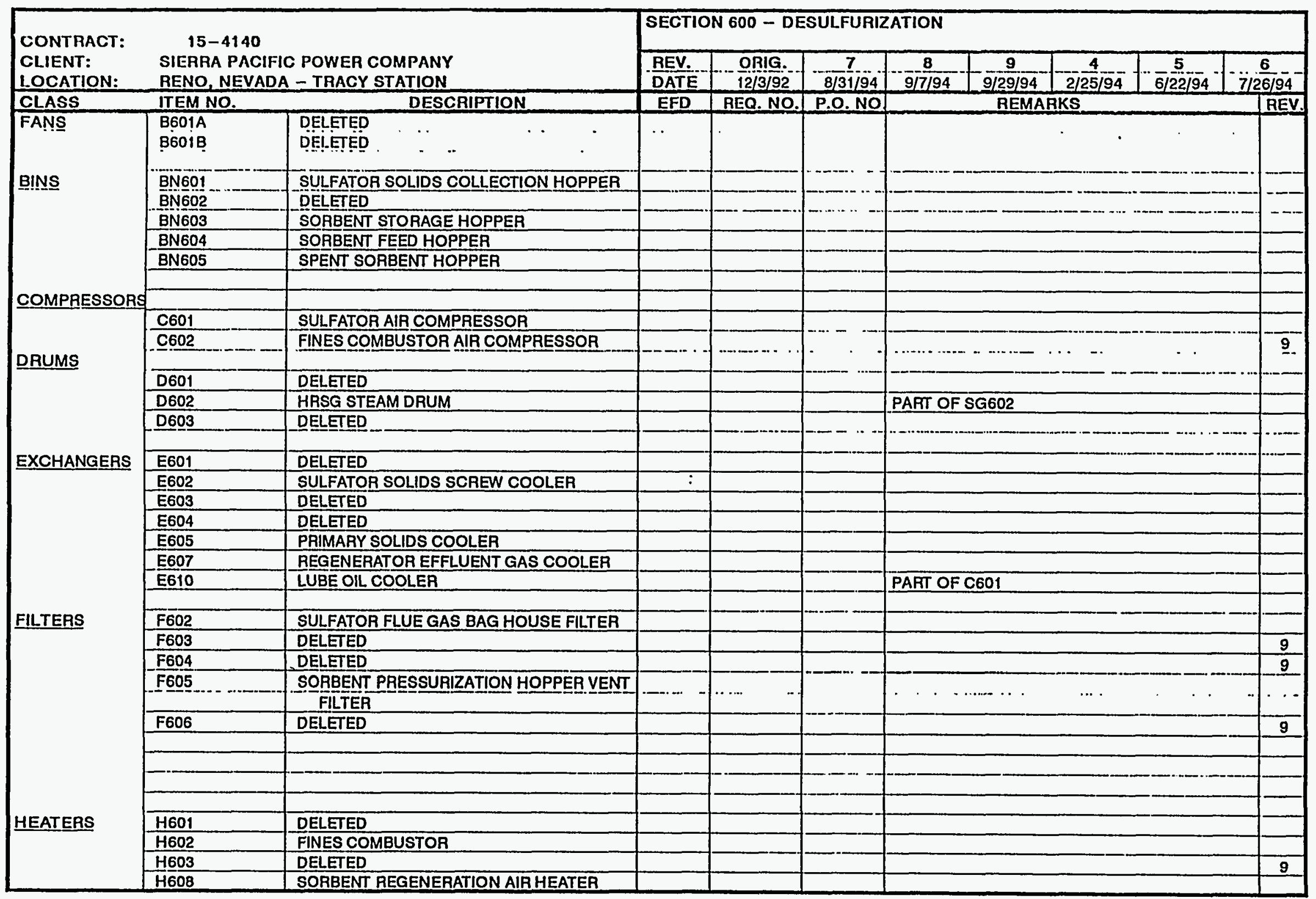




\section{EQUIPMENT LIST}

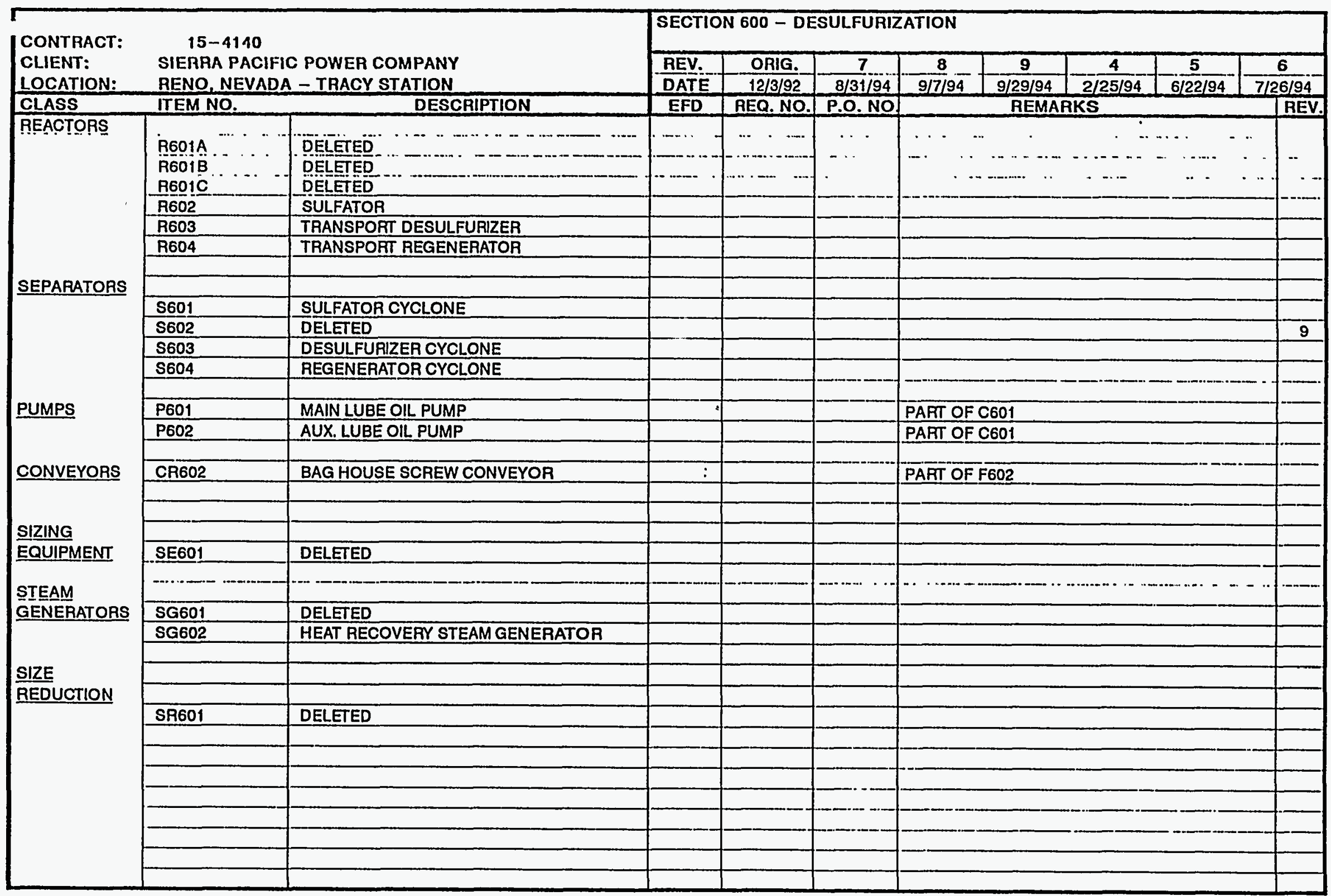




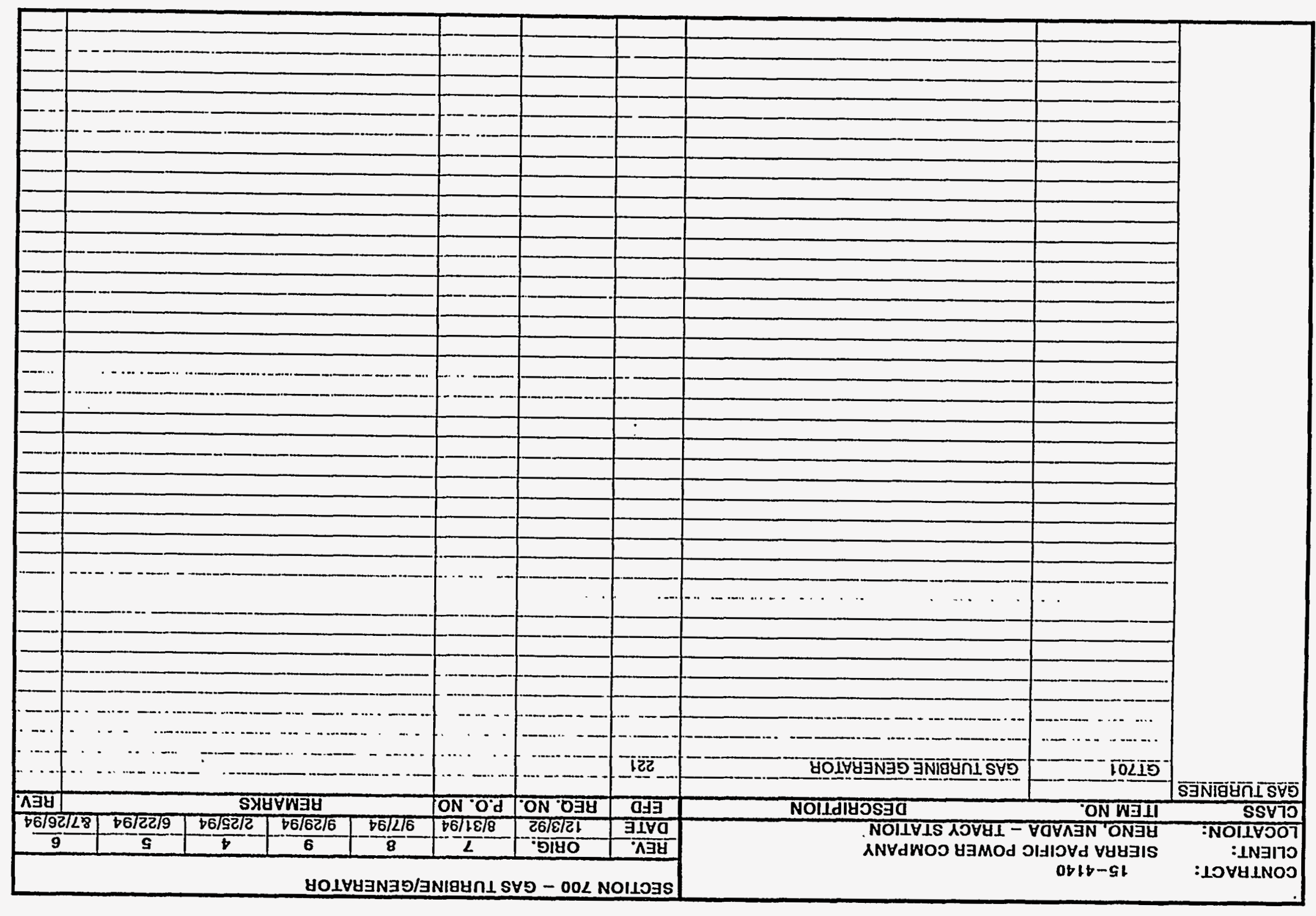

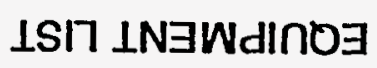

Iट $10 \mu \exists 9 \forall d$ 


\section{EQUIPMENT LIST}

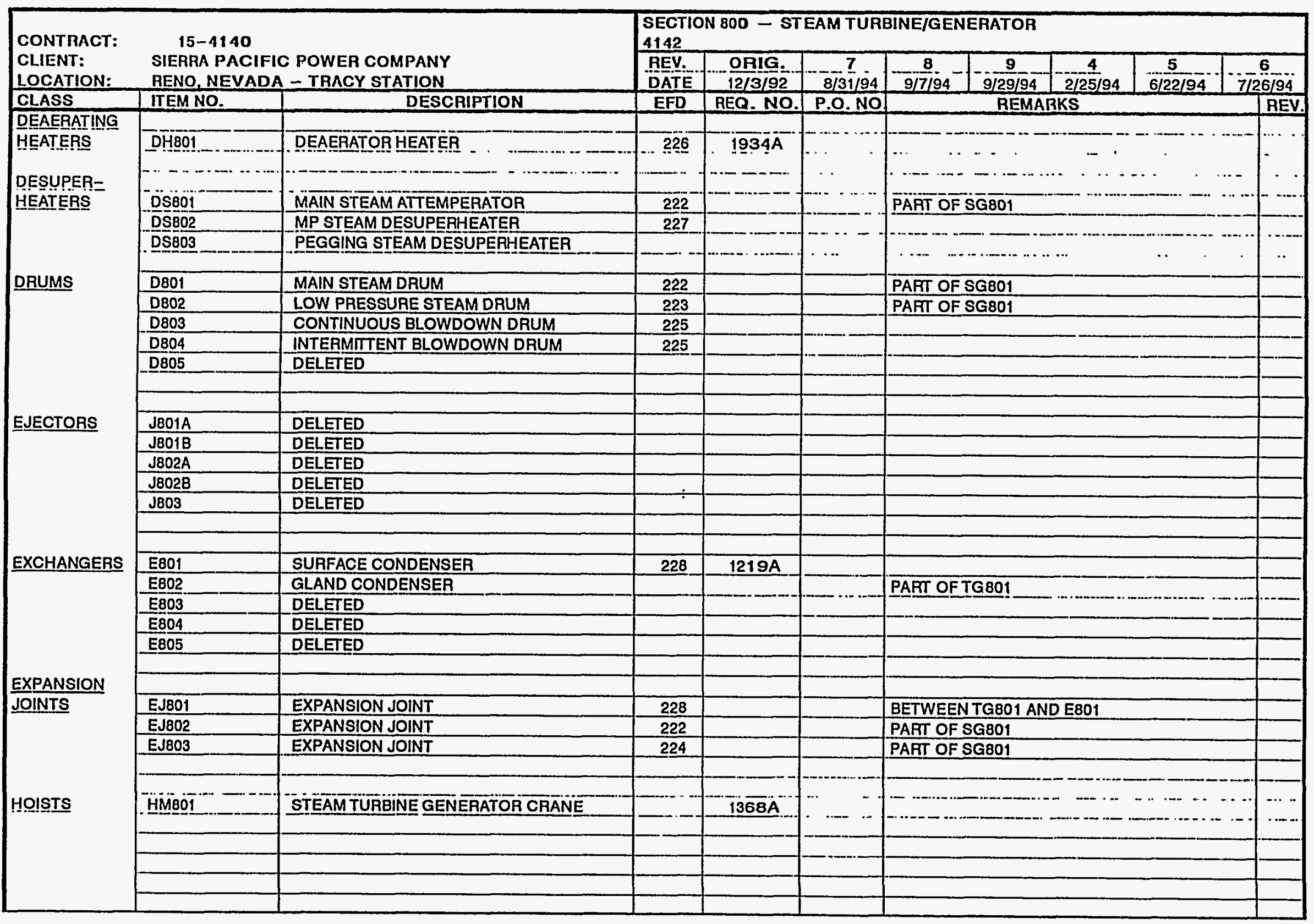




\section{EQUIPMENT LIST}

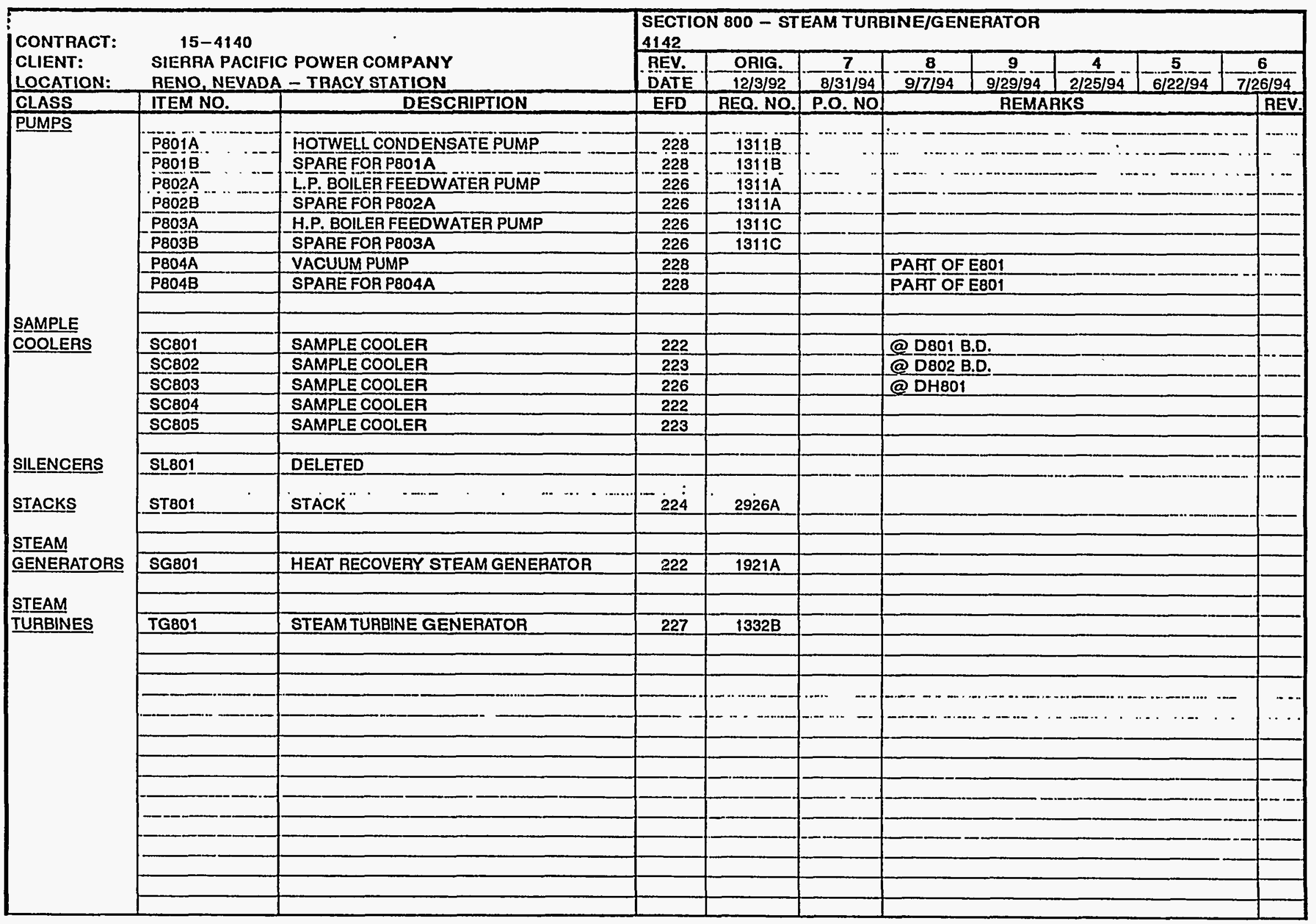




\section{EQUIPMENT LIST}

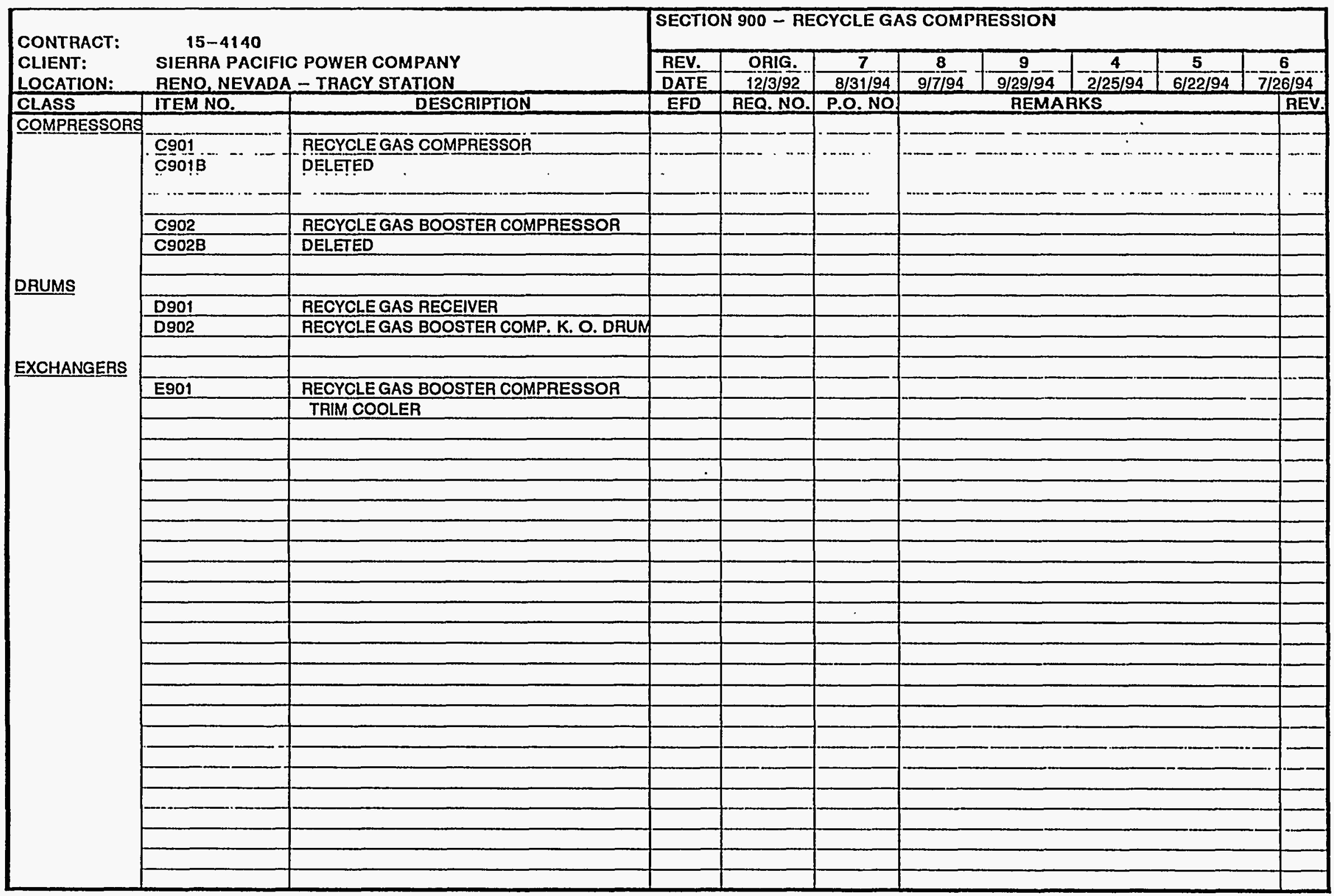




\section{EQUIPMENT LIST}

$F_{i}$

CONTRACT: $\quad 15-4140$

CLIENT: SIERRA PACIFIC POWER COMPANY

LOCATION: RENO, NEVADA - TRACY STATION

CLASS

\begin{tabular}{l|l|l}
$X$ & 1000 & DELETED \\
\hline
\end{tabular}

PACKAGES

MISC.

PUMPS

POWER BLOWDOWN TREATMENT PACKAGE

SECTION 1000 - WASTE WATER TREATMENT

4143

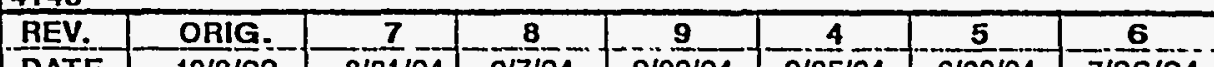

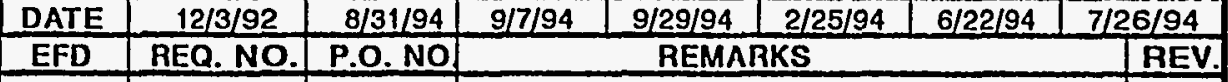

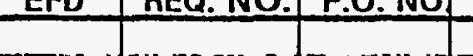

REMARKS

- .....

DIRTY WASTEWATER PUMPS

\begin{tabular}{|l|l|}
\hline P1001A & DIRTY WASTEWATER \\
\hline P1001B & SPARE FOR P1001A \\
\hline
\end{tabular}

\begin{tabular}{|l|l}
\hline P1002A & CLEAN WASTEWATER PUMP \\
\hline P1002B
\end{tabular}

\begin{tabular}{|l|l}
\hline P1002B & SPARE FOR P1002A \\
\hline
\end{tabular}

\begin{tabular}{|l|l}
\hline P1003A & CLARIFIER EFFLUENT PUMP \\
\hline PIO03B
\end{tabular}

\begin{tabular}{|l|l}
\hline P1003B & SPARE FOA P1003A \\
\hline P1004A
\end{tabular}

\begin{tabular}{|l|l}
\hline $1004 A$ & CLARIFIER BLOWDOWN PUMP
\end{tabular}

\begin{tabular}{|l|l}
\hline P1004B & SPARE FOR P1004A \\
\hline P1005A
\end{tabular}

\begin{tabular}{|l|l}
\hline P1005A & SLUDGE SUMP PUMP \\
\hline
\end{tabular}

\begin{tabular}{l|l} 
P1005B & SPARE FOR P1005A
\end{tabular}

\begin{tabular}{|l|l}
\hline P1006A & THICKENER SLUDGE PUMP \\
\hline
\end{tabular}

\begin{tabular}{|l|l}
\hline P1006B & SPARE FOR P1006A \\
\hline P1007A
\end{tabular}

\begin{tabular}{|l|l}
\hline P1007A & CAUSTIC PUMP \\
\hline
\end{tabular}

\begin{tabular}{|l|l}
\hline P1007B & SPARE FOR P1007A \\
\hline
\end{tabular}

\begin{tabular}{l|l}
\hline P1OOBA & SODA ASH PUMP \\
\hline PIOOBB
\end{tabular}

\begin{tabular}{l|l}
\hline P1008B & SPARE FOR P100BA \\
\hline
\end{tabular}

\begin{tabular}{l|l}
\hline P1009A & MAGNESIUM CHLORIDE PUMP
\end{tabular}

\begin{tabular}{|l|l}
\hline P1009B & SPARE FOR P1009A \\
\hline
\end{tabular}

CLAPIFIER

CL1001

REACTOR CLARIFIER

FILTERS

FEEDER

CLب!100?

TH! IEKENER

F1001

PLATE FILTER PRESS

DRUMS

TANKS

\begin{tabular}{|c|c|}
\hline FR1001 & SODA ASH FEEDER \\
\hline D1001 & CAUSTIC TANK \\
\hline TK1001 & CLARIFIER EFFLUENT AGING TANK \\
\hline TK1002 & MAGNESIUM CHLORIDE TANK \\
\hline TK1003 & SODA ASHTANK \\
\hline
\end{tabular}

\begin{tabular}{|r|r|}
\hline 339 & \\
\hline 339 & \\
\hline 339 & \\
\hline & \\
\hline & \\
\hline & \\
\hline & \\
\hline & \\
\hline & \\
\hline & \\
\hline & \\
\hline & \\
\hline & \\
\hline & \\
\hline & \\
\hline & \\
\hline & \\
\hline
\end{tabular}

FOR WASTEWATER POND

PAFT OF PG1001

PART OF PG1001

PART OF PG1001

PART OF PG1001

PART OF PG1001

PART OF PG1001

PART OF PG 1001

PAPI OF PG1001

PART OF PG100

PART OF PG1001

PART OF PG1001

PART OF PG100

PART OF PG1001

PART OF PG1001

PART OF PG1001

PART OF PG1001

PAFT OF PG1001

PART OF PG1001

PART OF PG1001

PAFT OFPG1001

PART OF PG1001

PART OF PG1001 


\section{EQUIPMENT LIST}

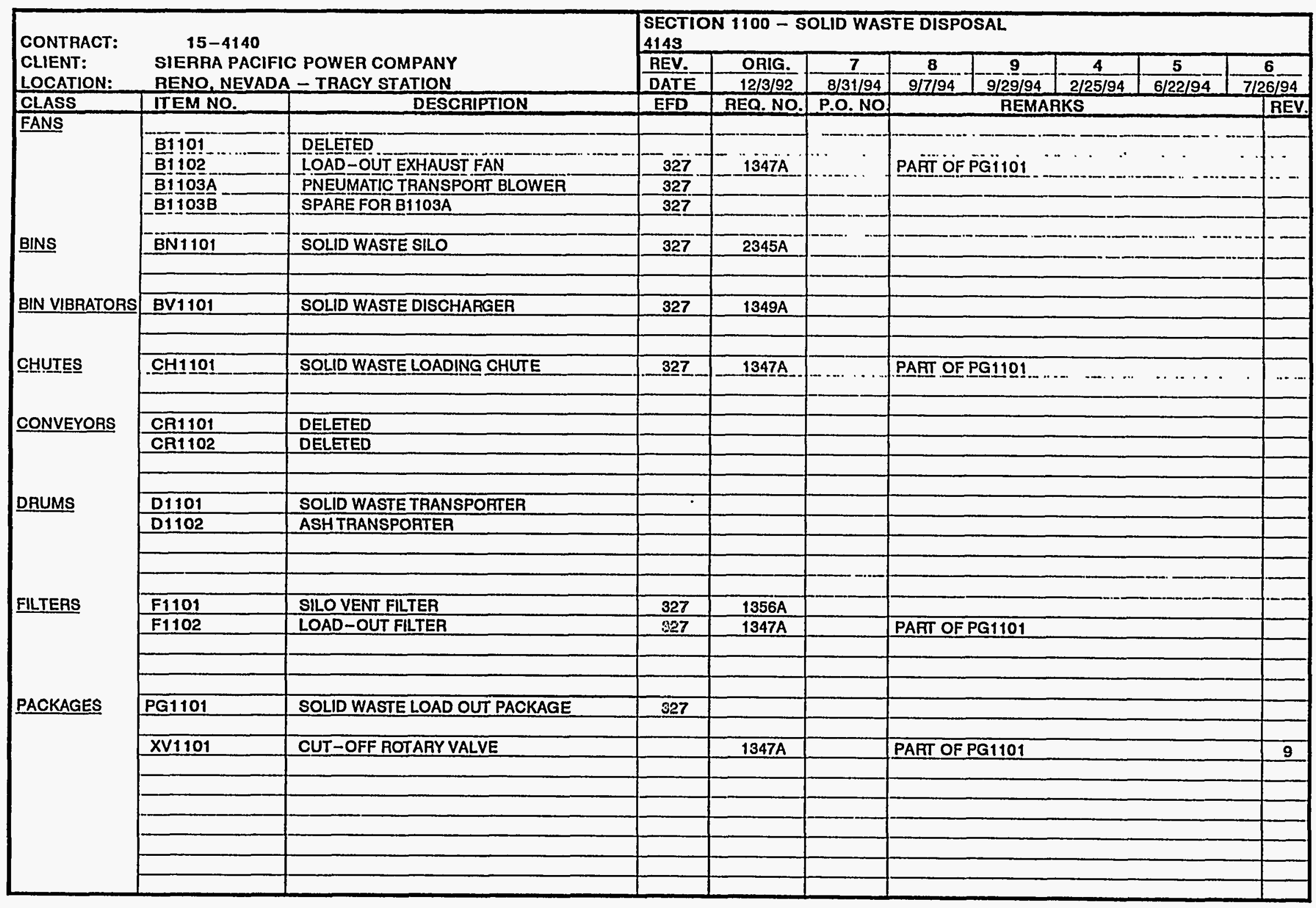




\section{EQUIPMENT LIST}

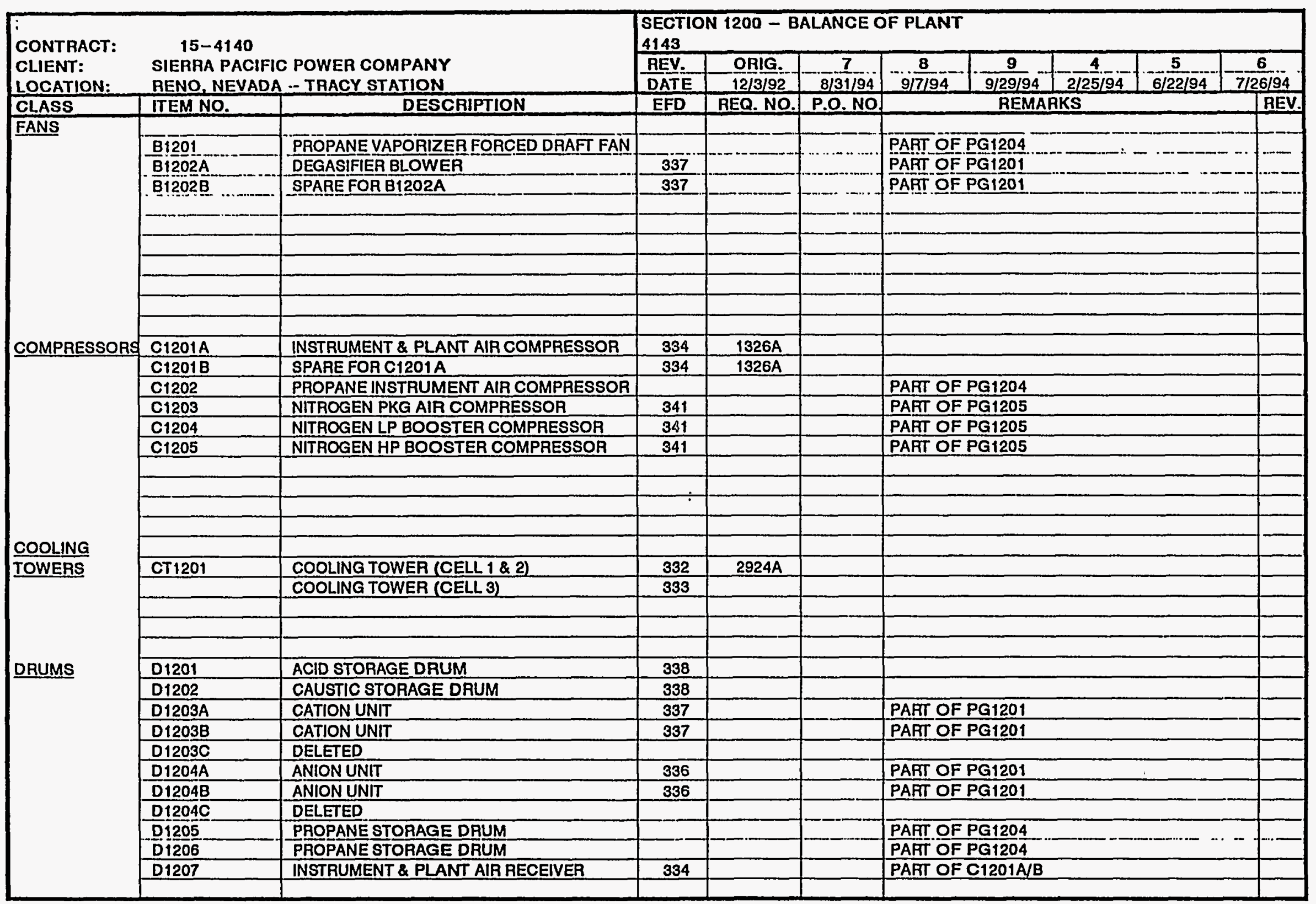




\section{EQUIPMENT LIST}

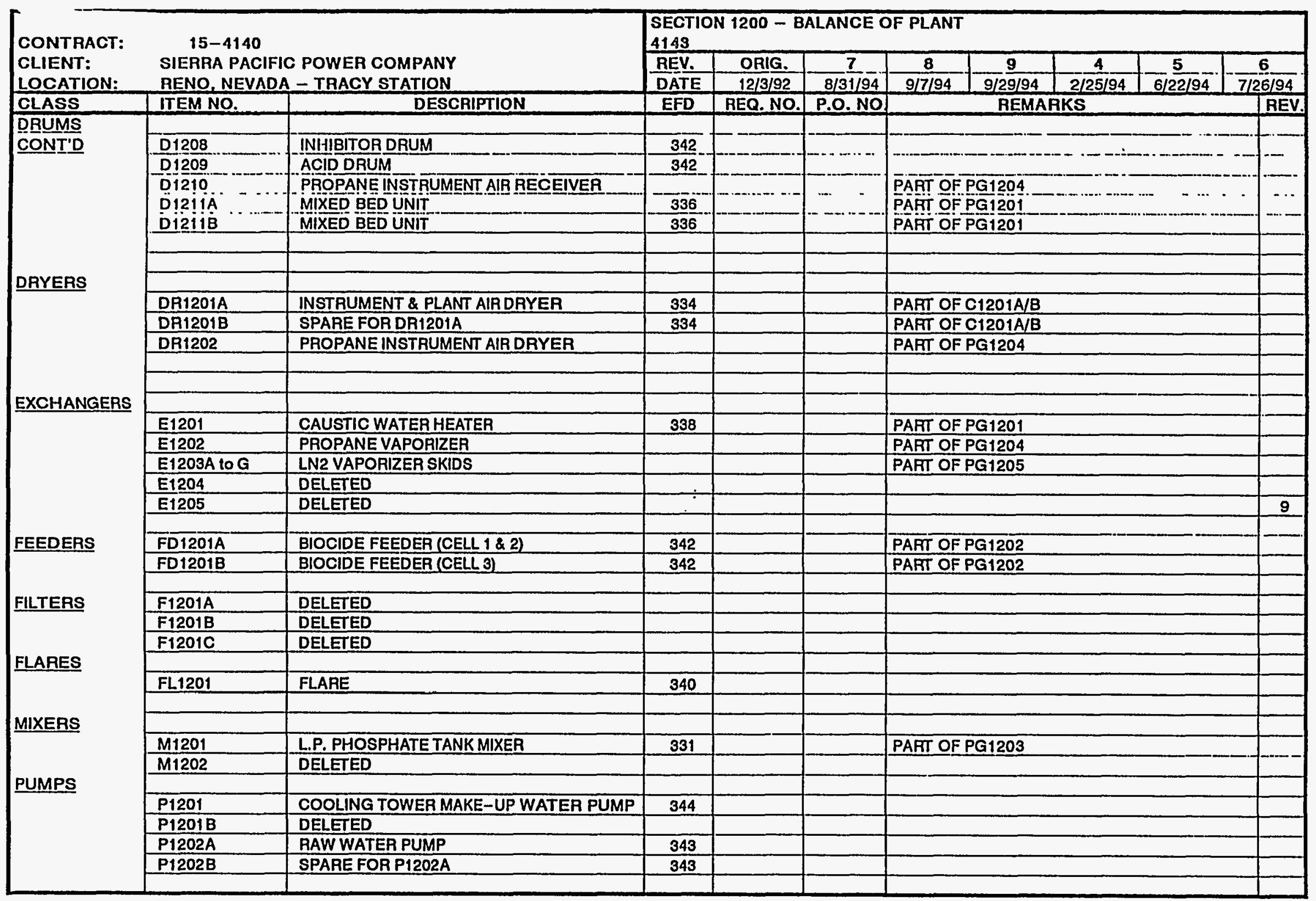




\section{EQUIPMENT LIST}

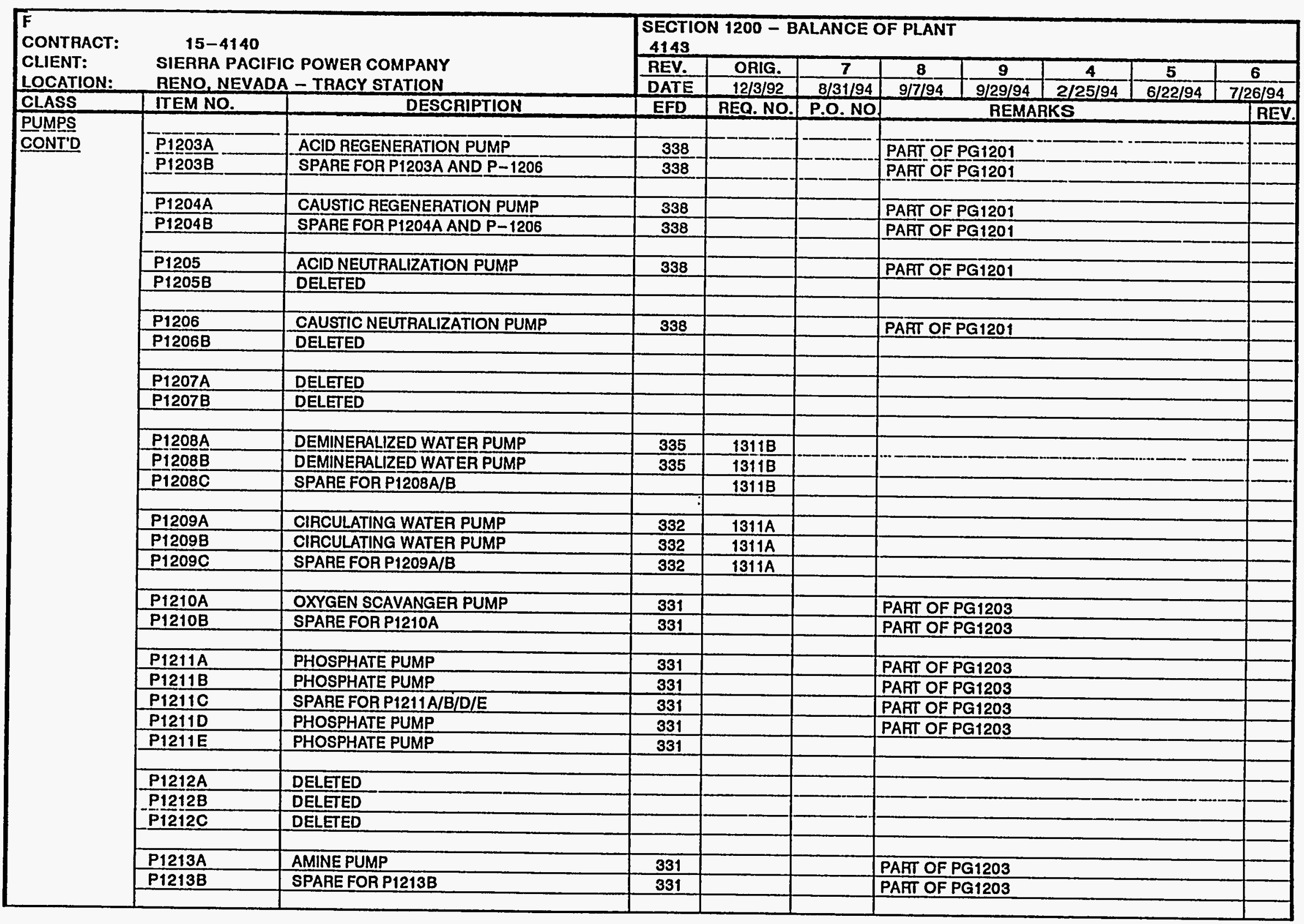




\section{EQUIPMENT LIST}

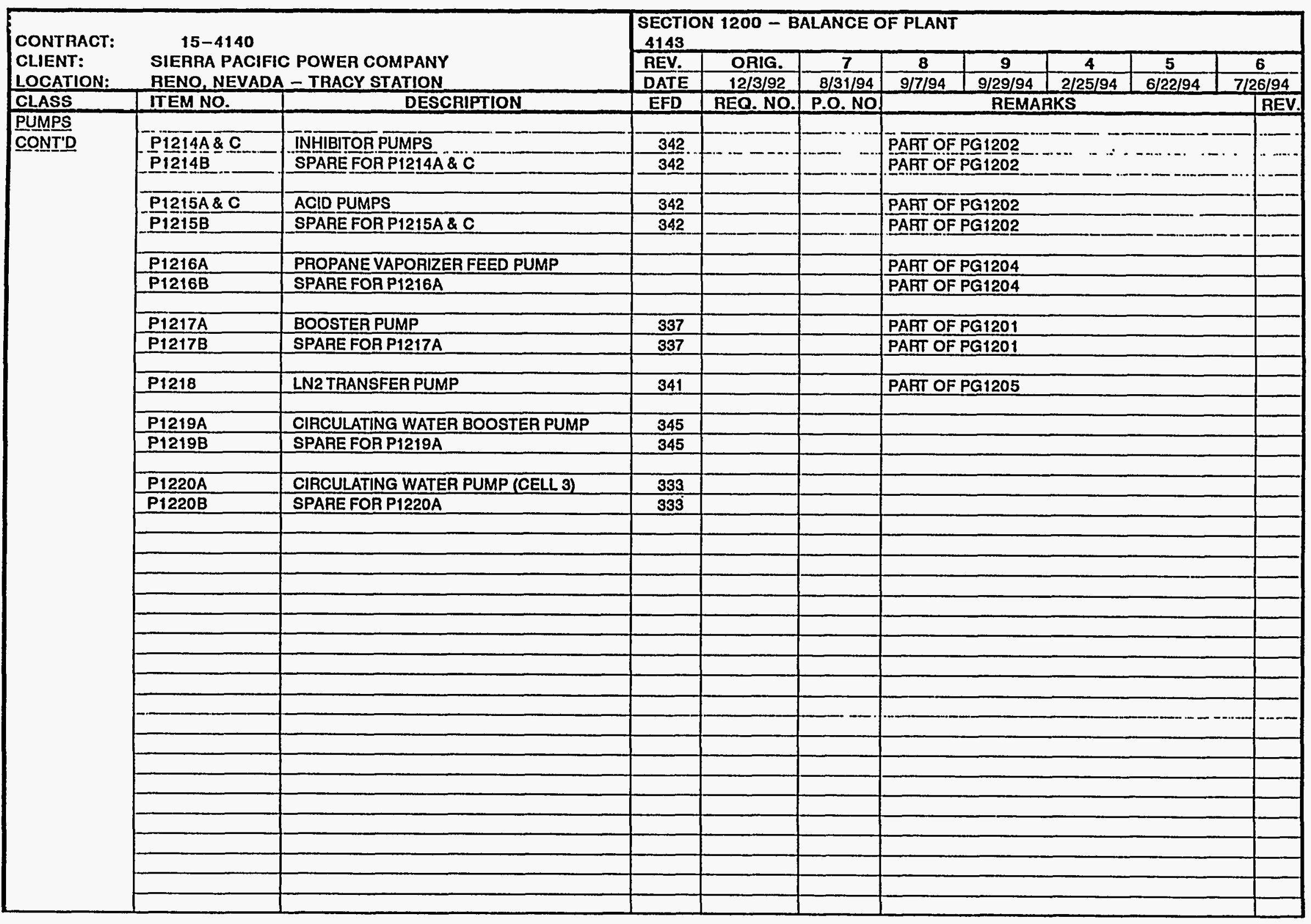




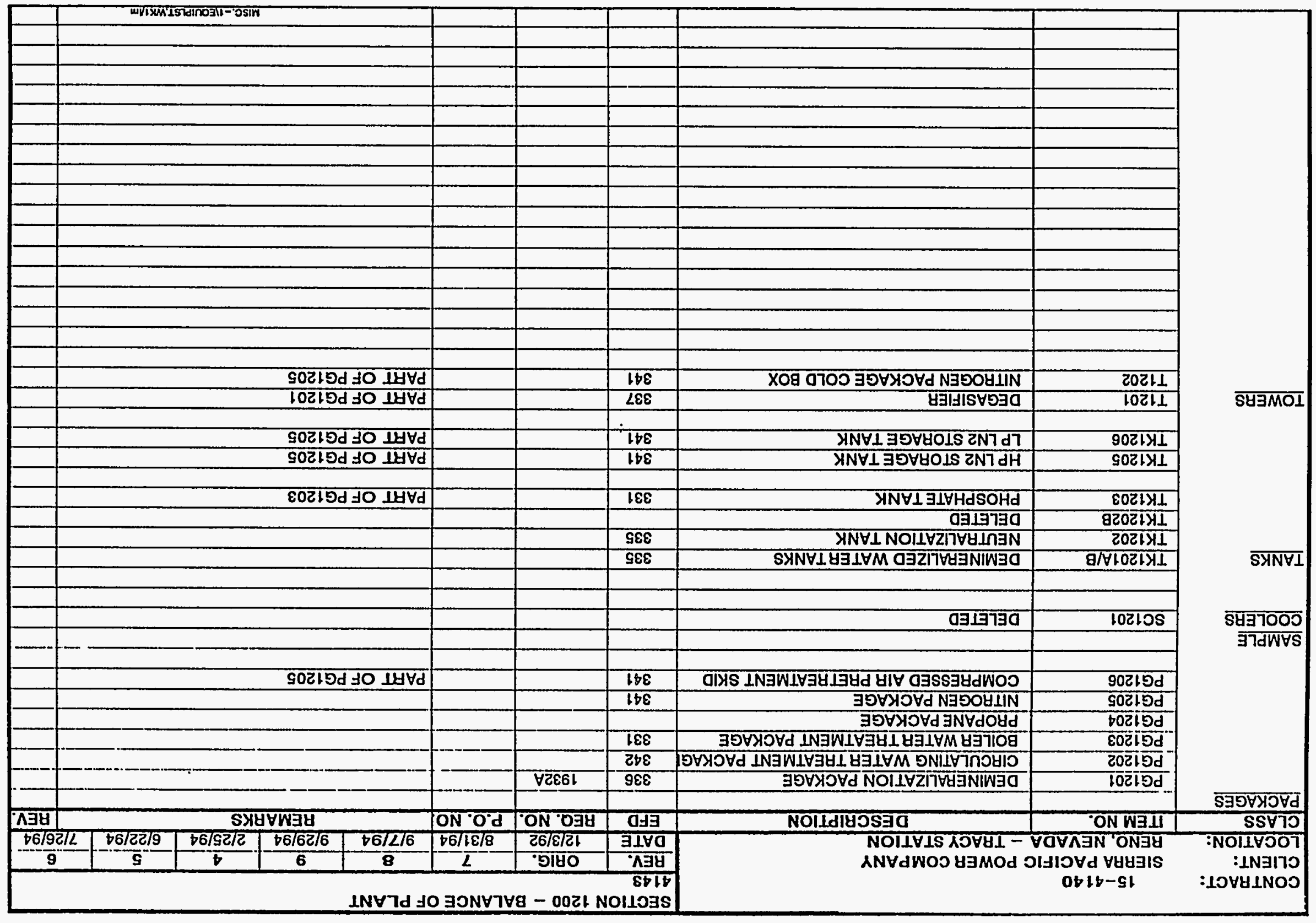

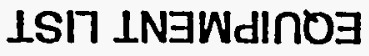




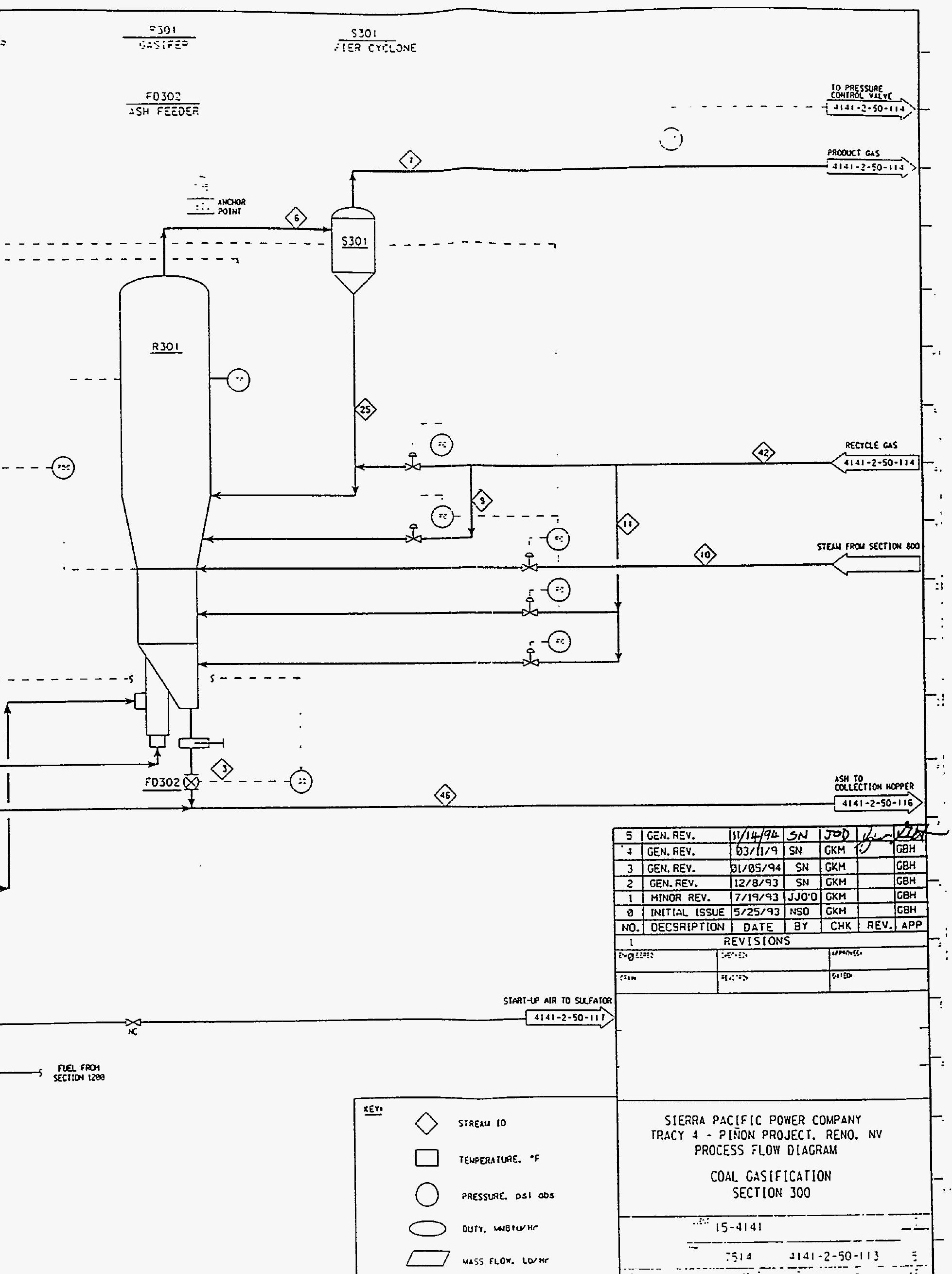




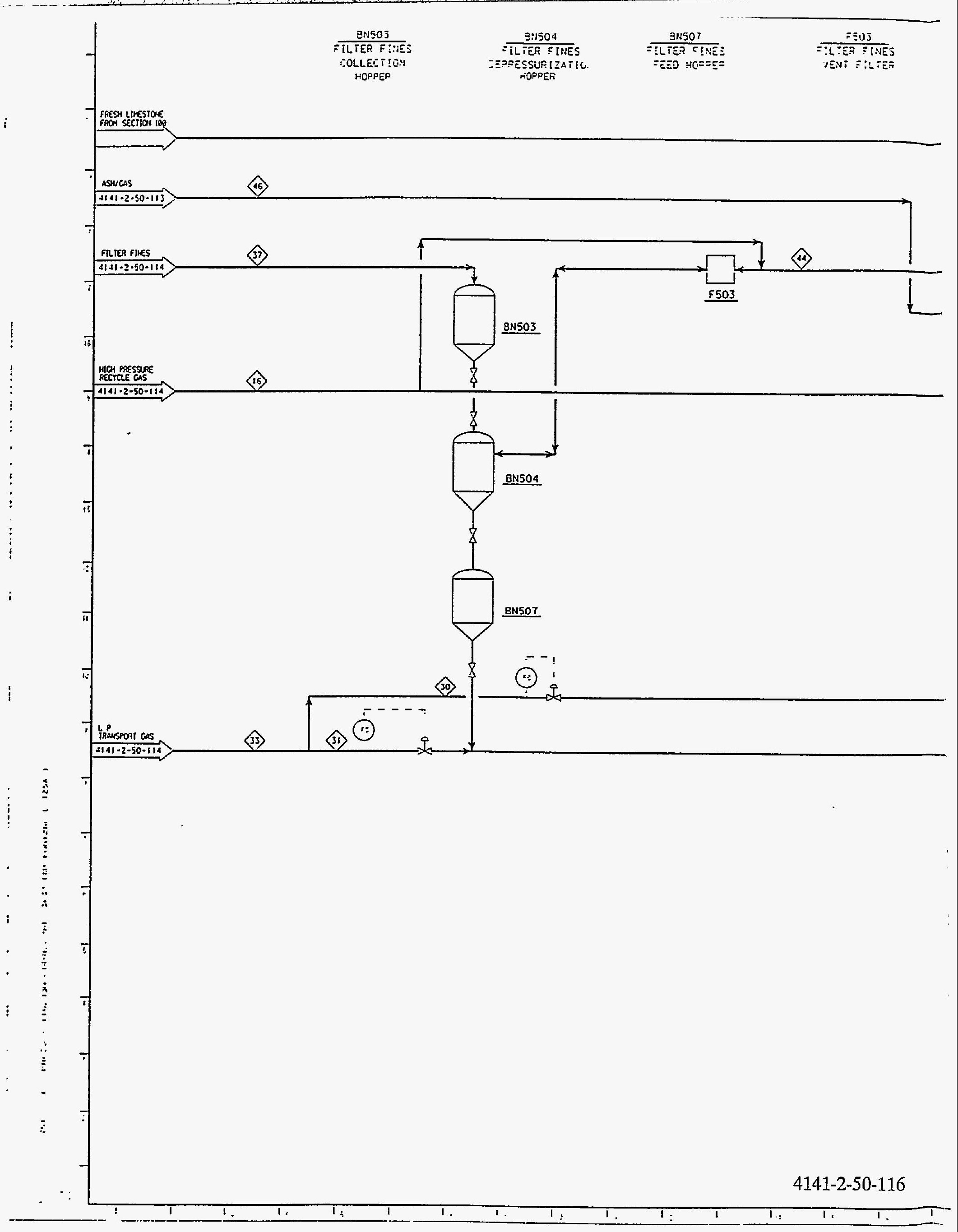




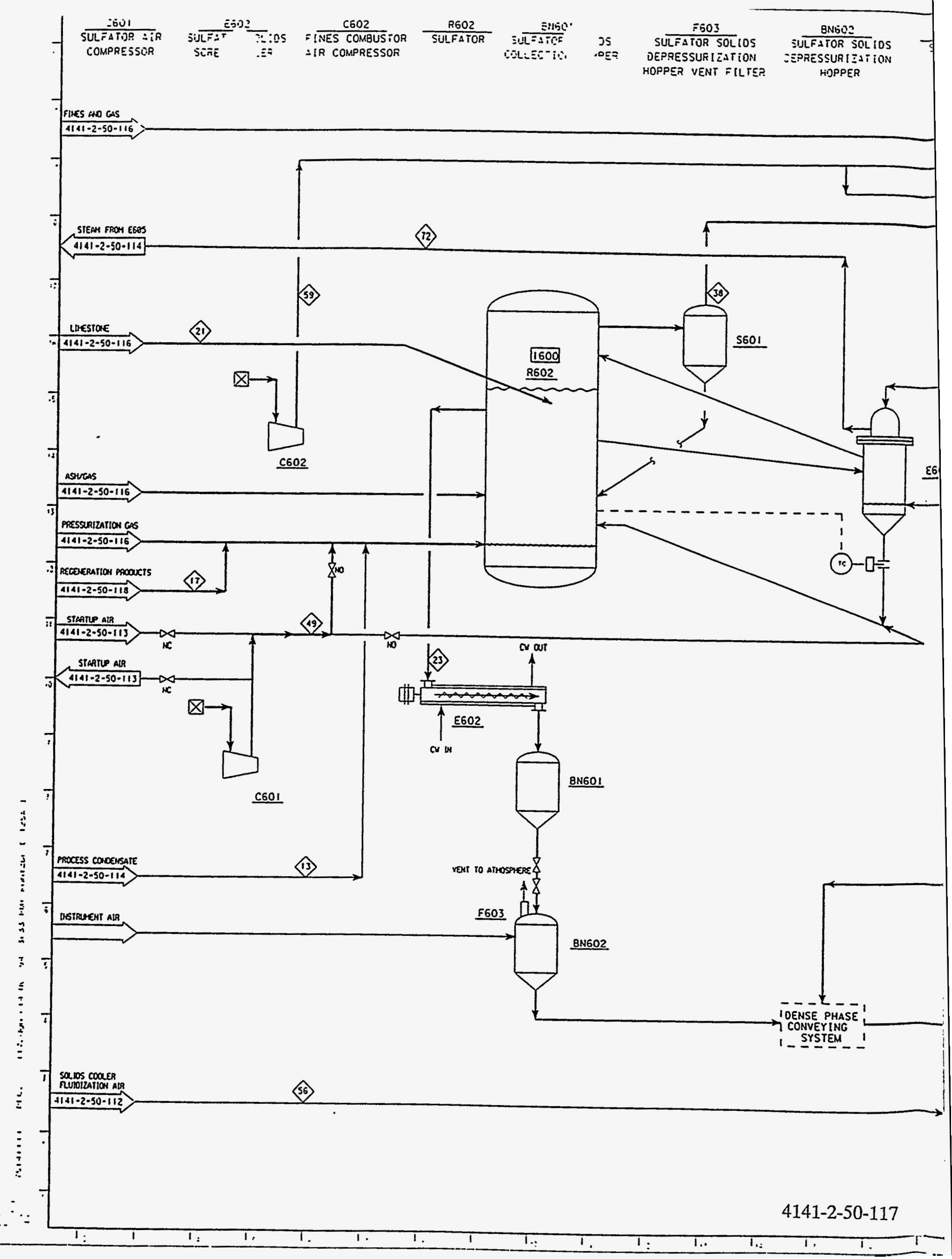




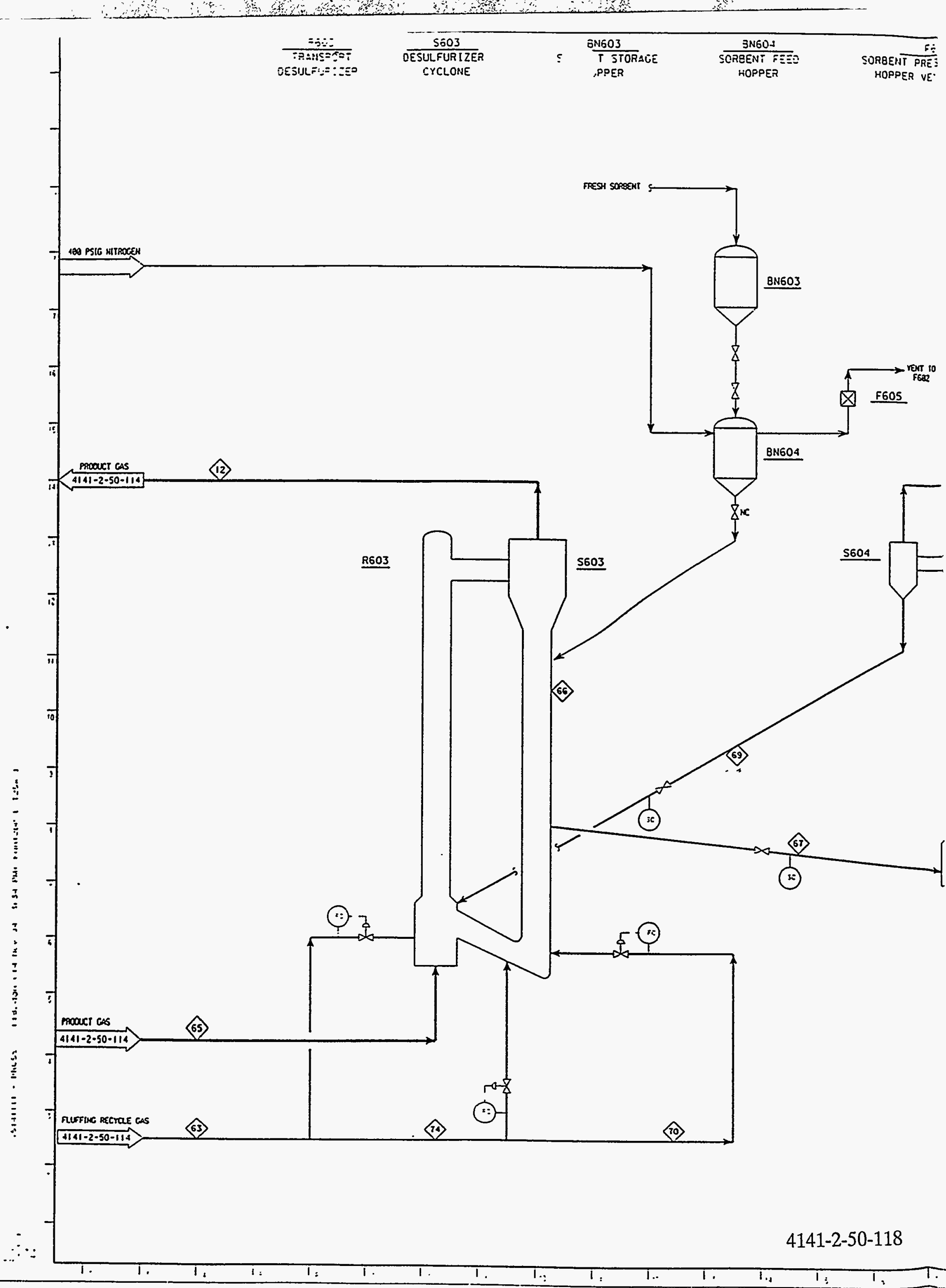




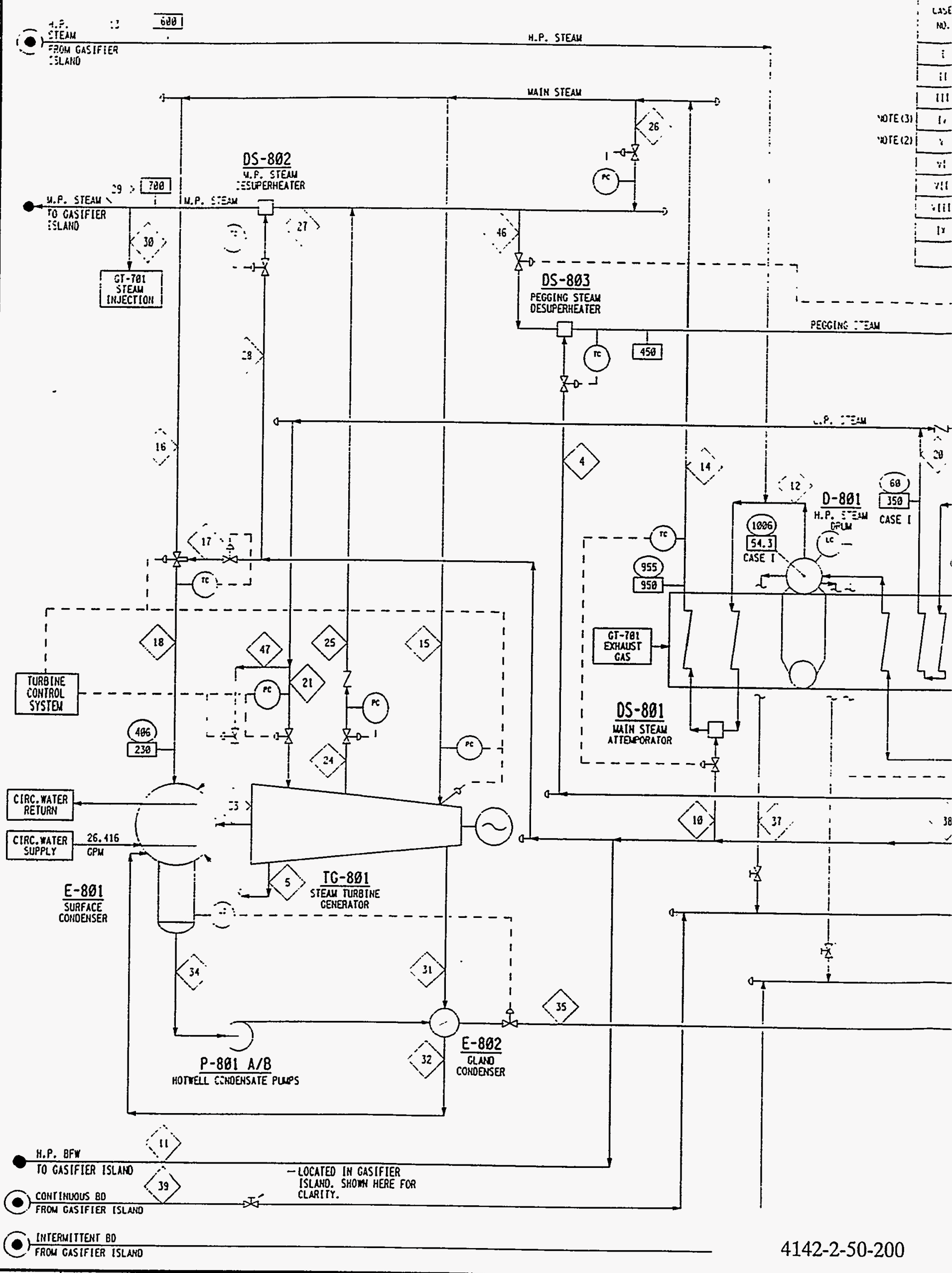




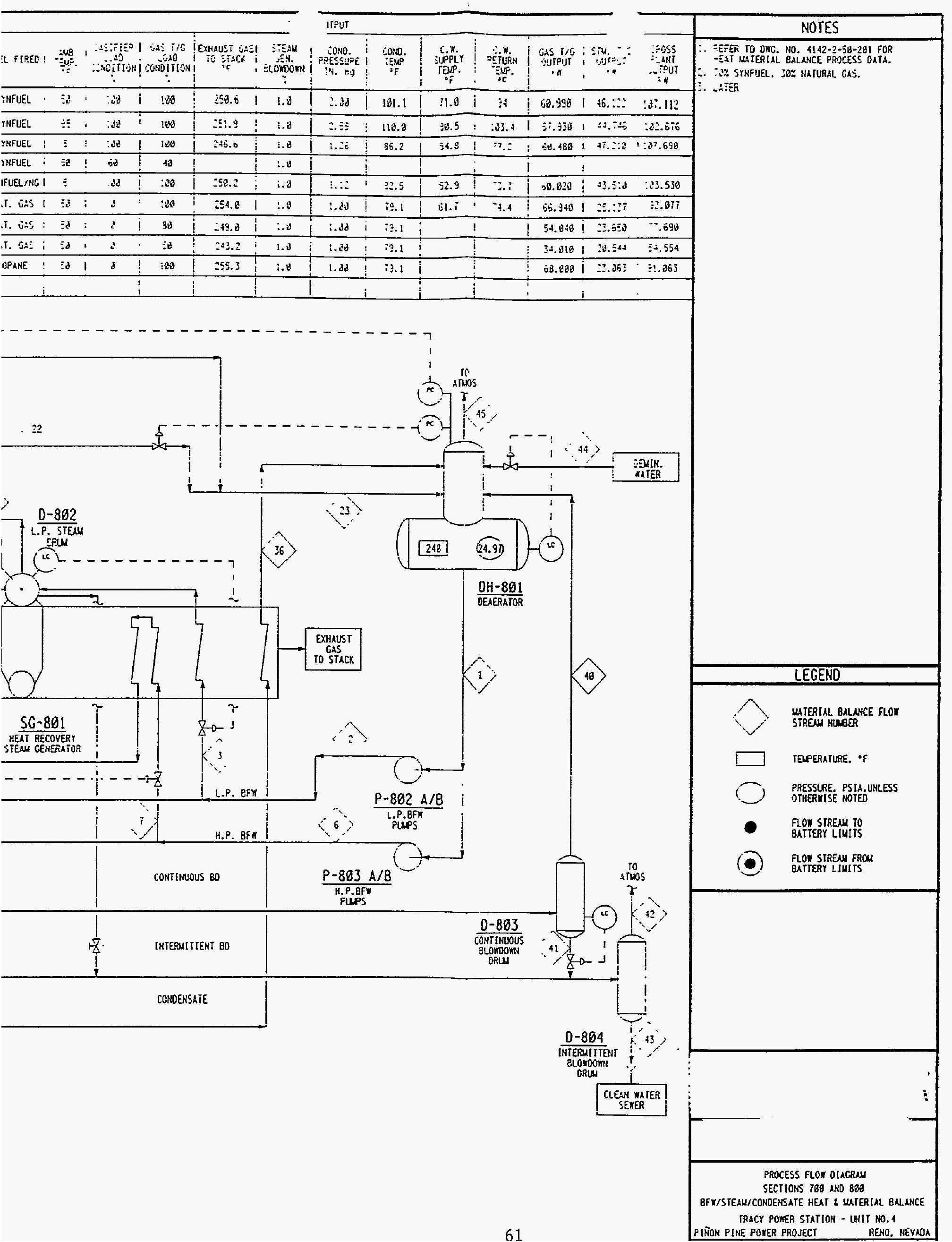




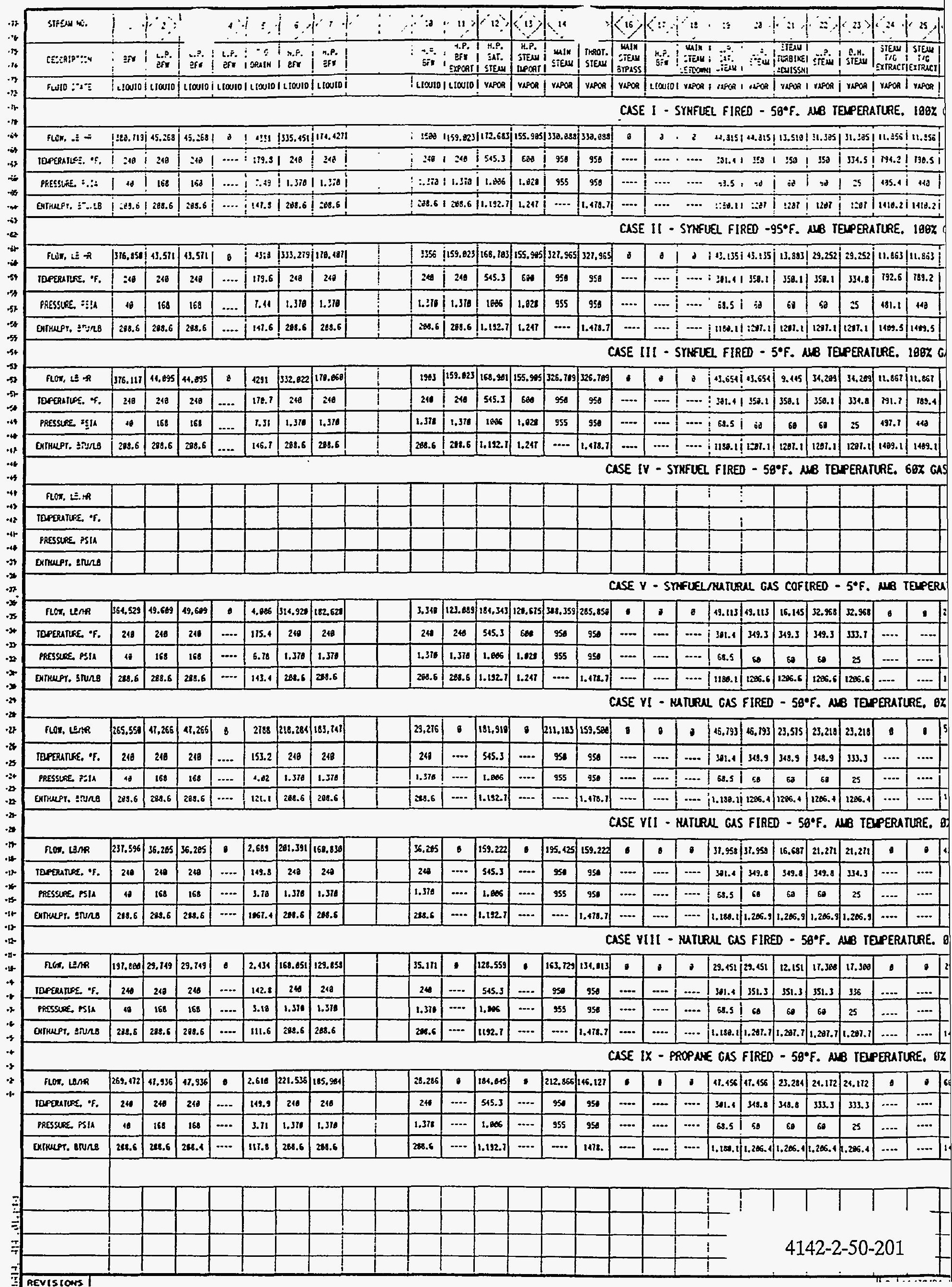




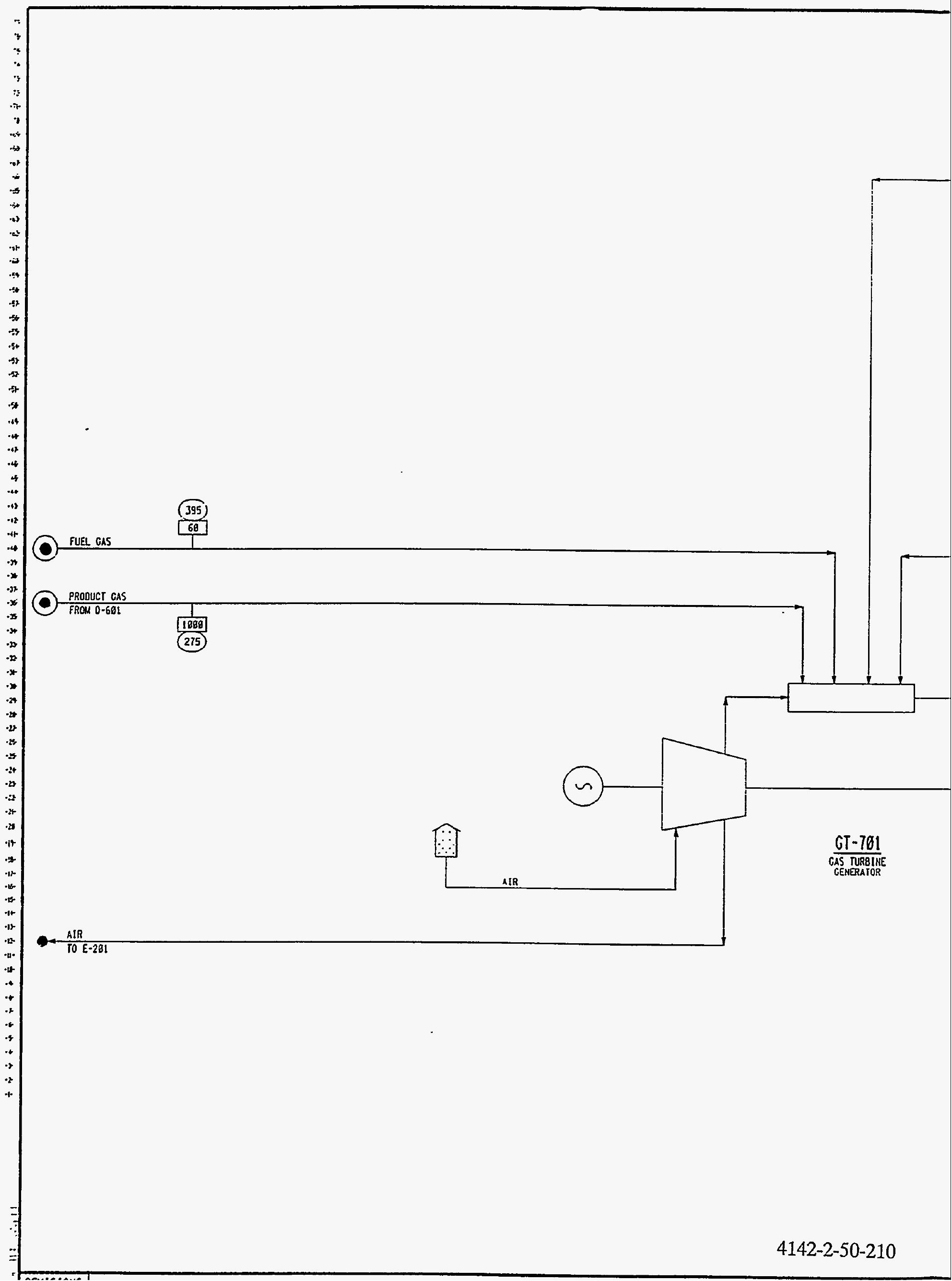




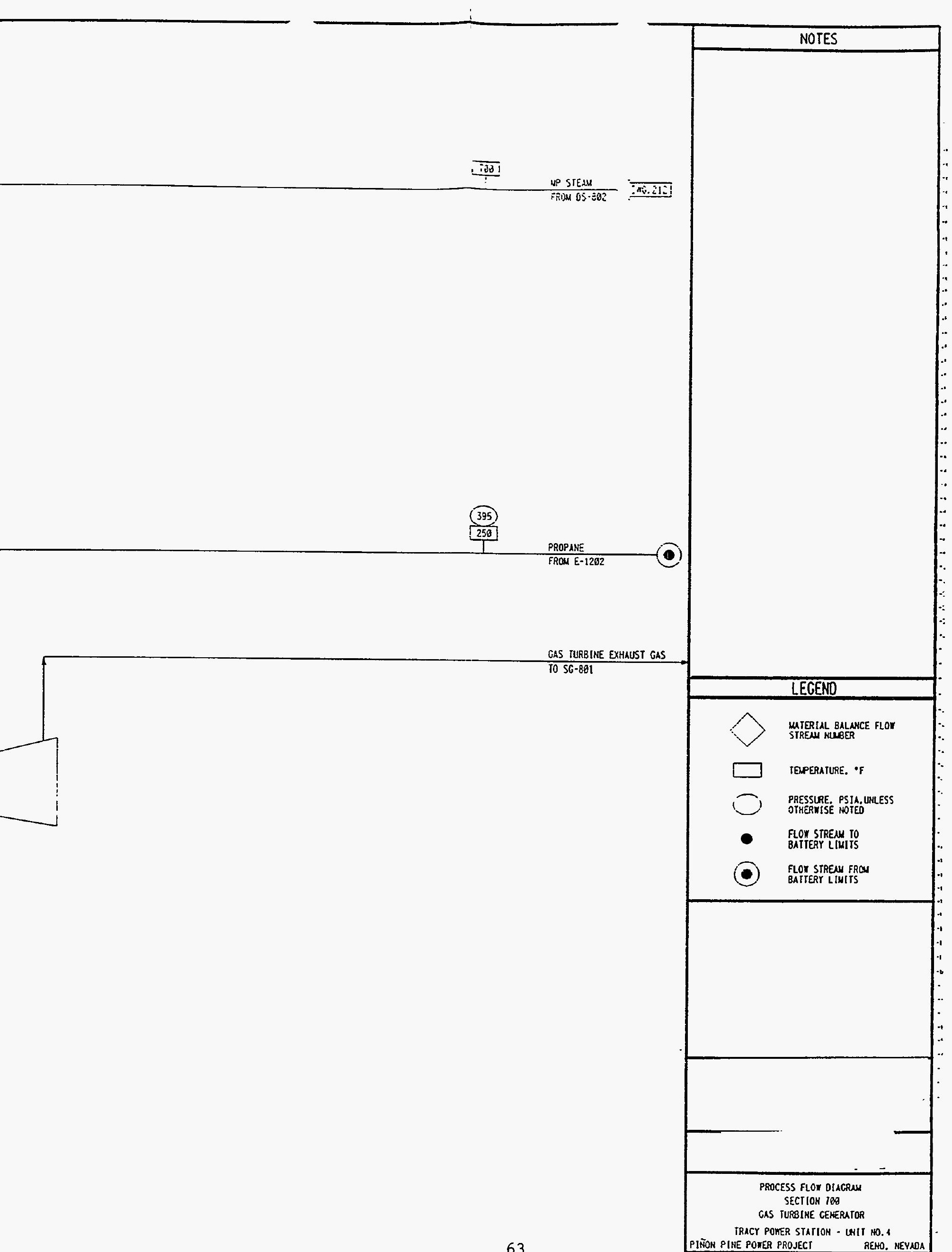




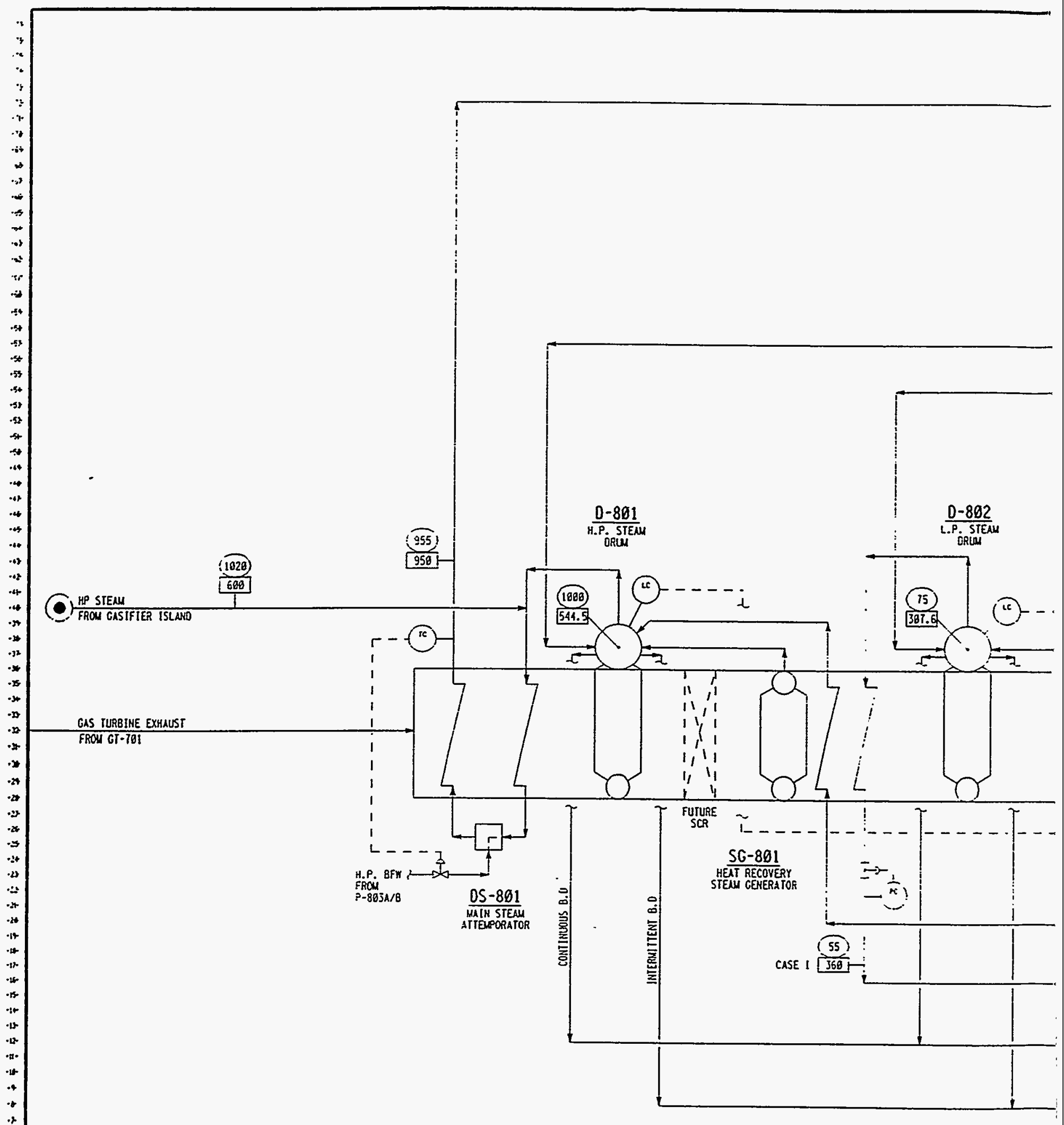




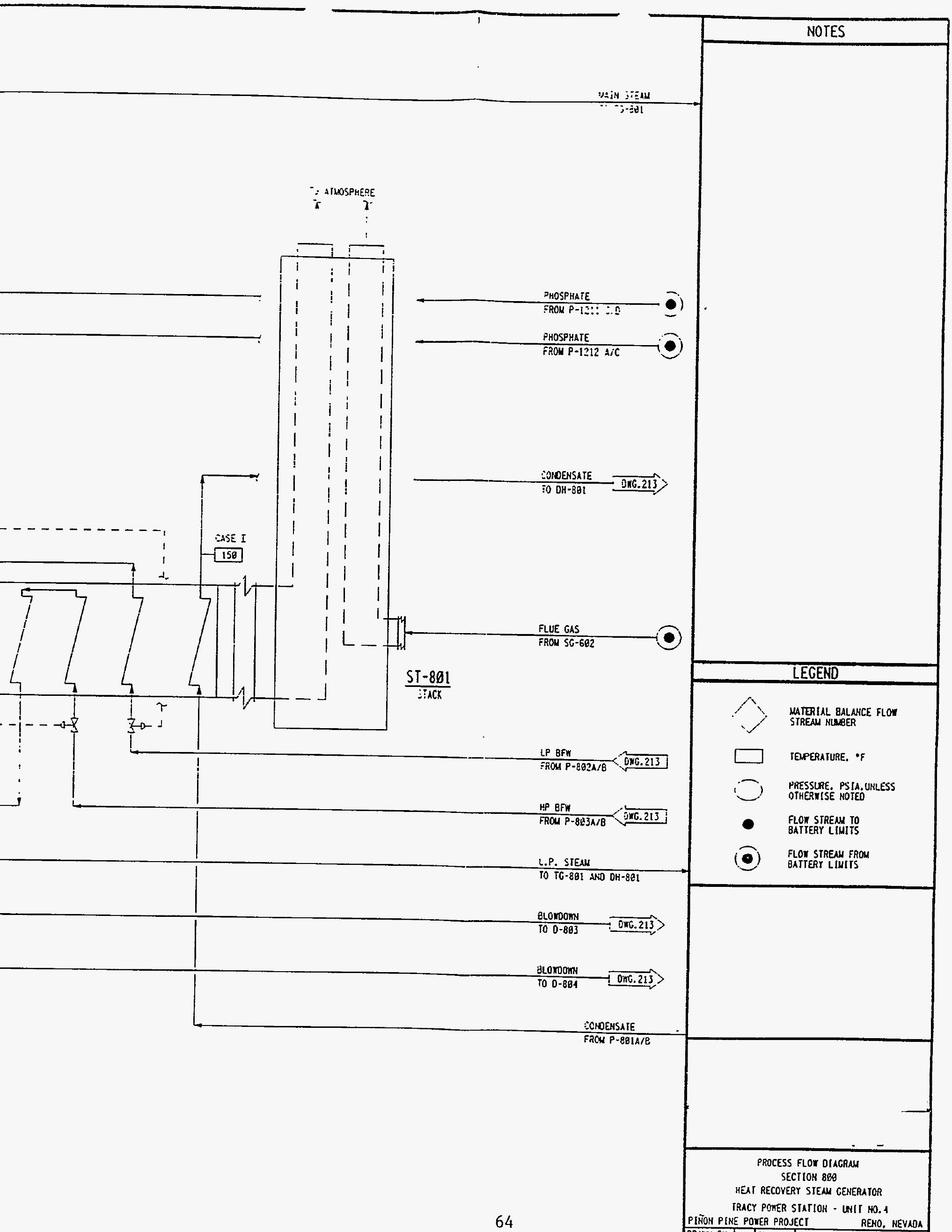




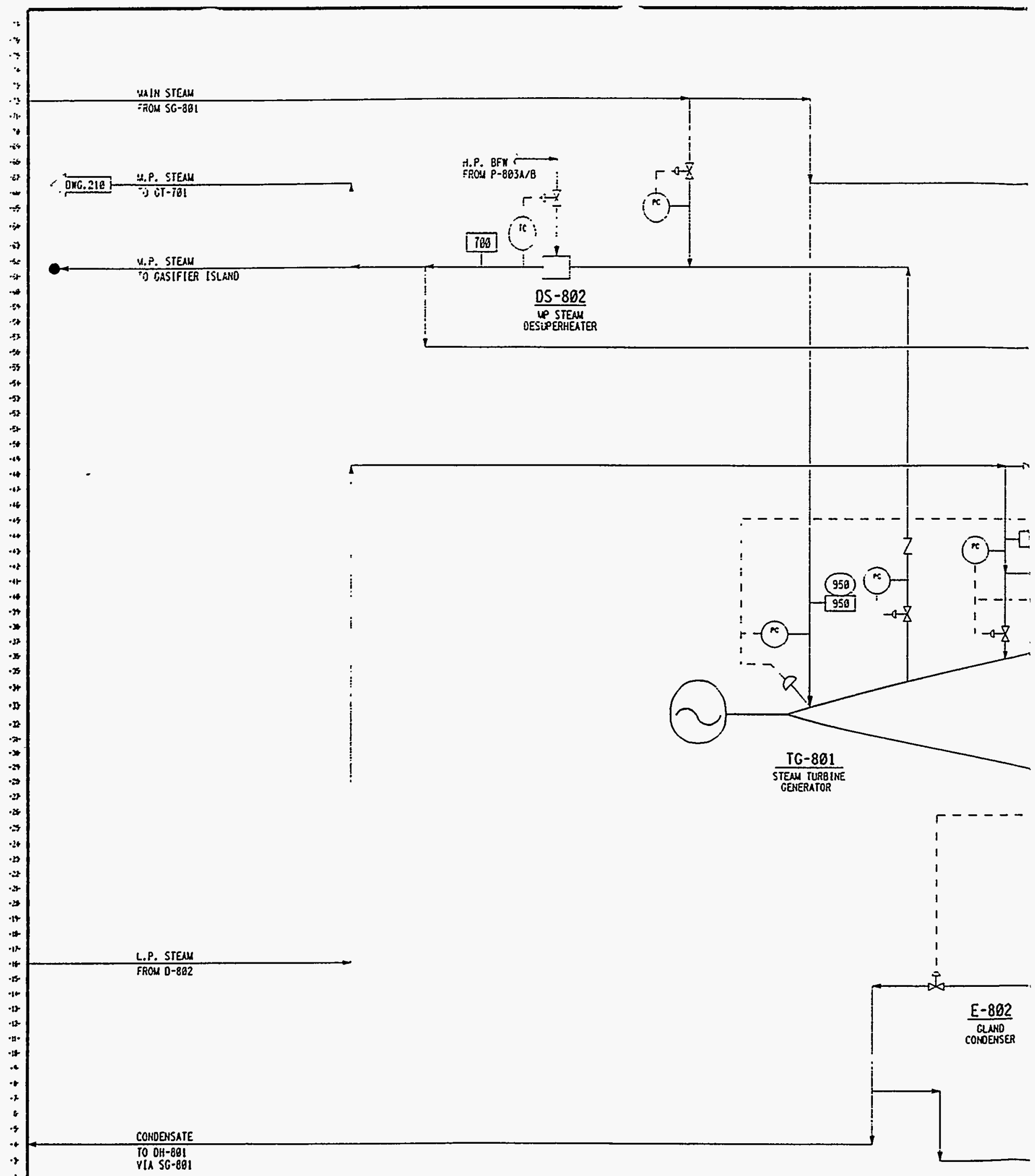




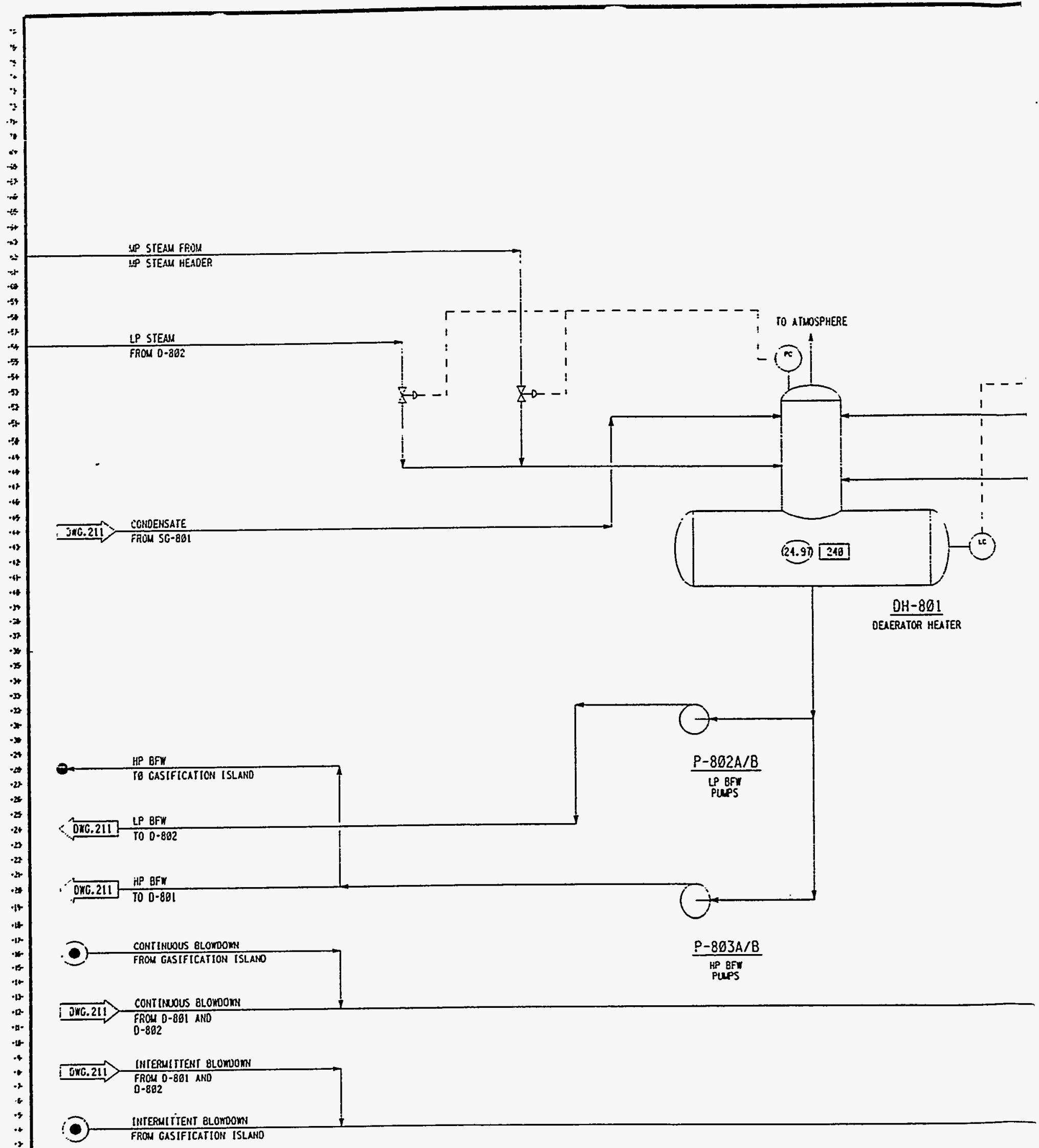




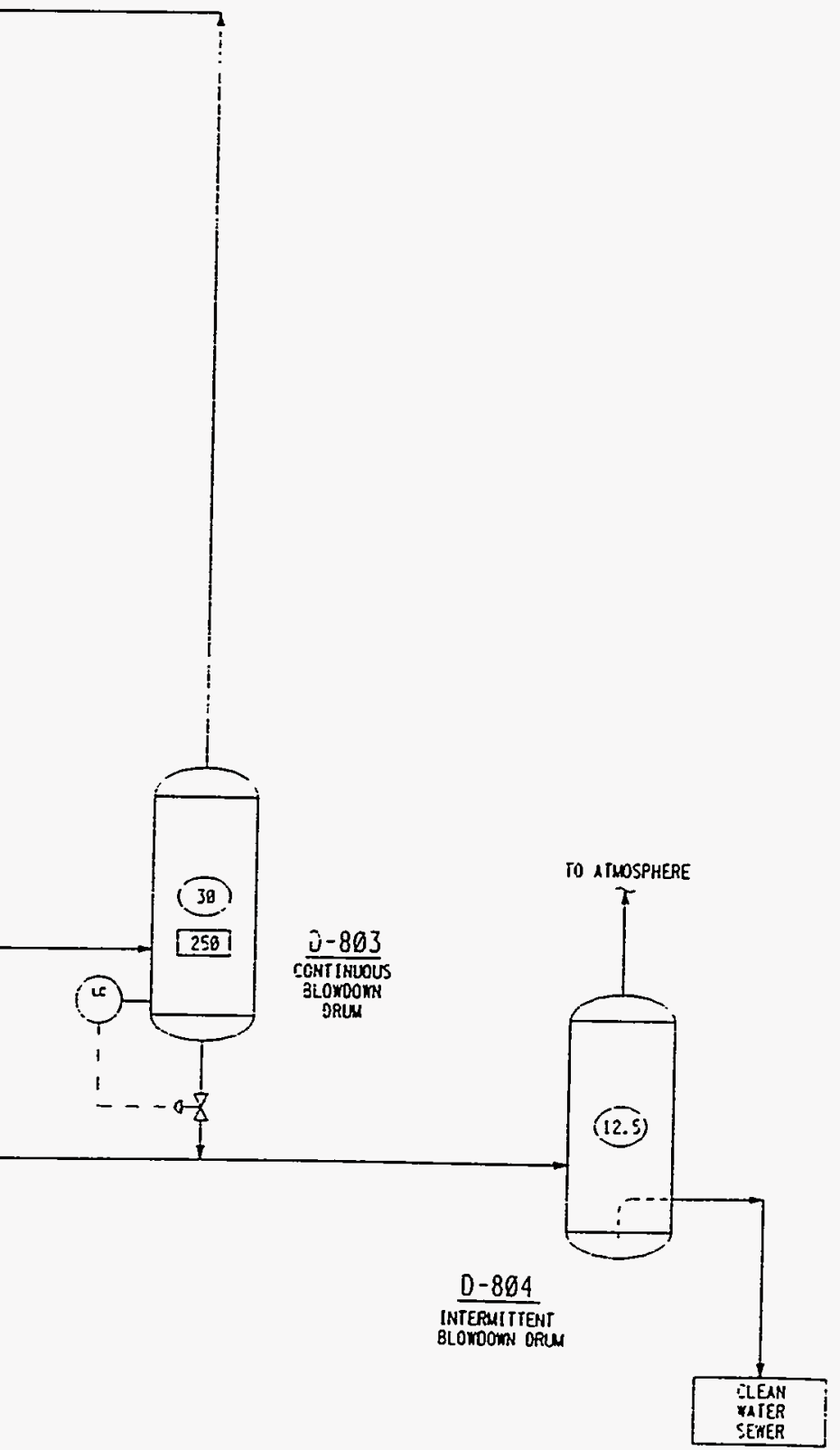

TEMPERA TURE. 'F

PRESSLRE. MSIA.UNLESS DTHERNISE NOTEO

FLOT STREAM TO BATTERY LIMITS

(ब)

FLON SIREAN FROM BATTERY LINITS

PROCESS FLOY OLACRAH SECIION 880 DEAERATOR HEATER \& BLONOONN ORLMS TRACY POTER STATION - UWIT MO.1 PIÑON PINE PONER PROJECT RENO. MEYANA 


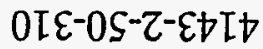

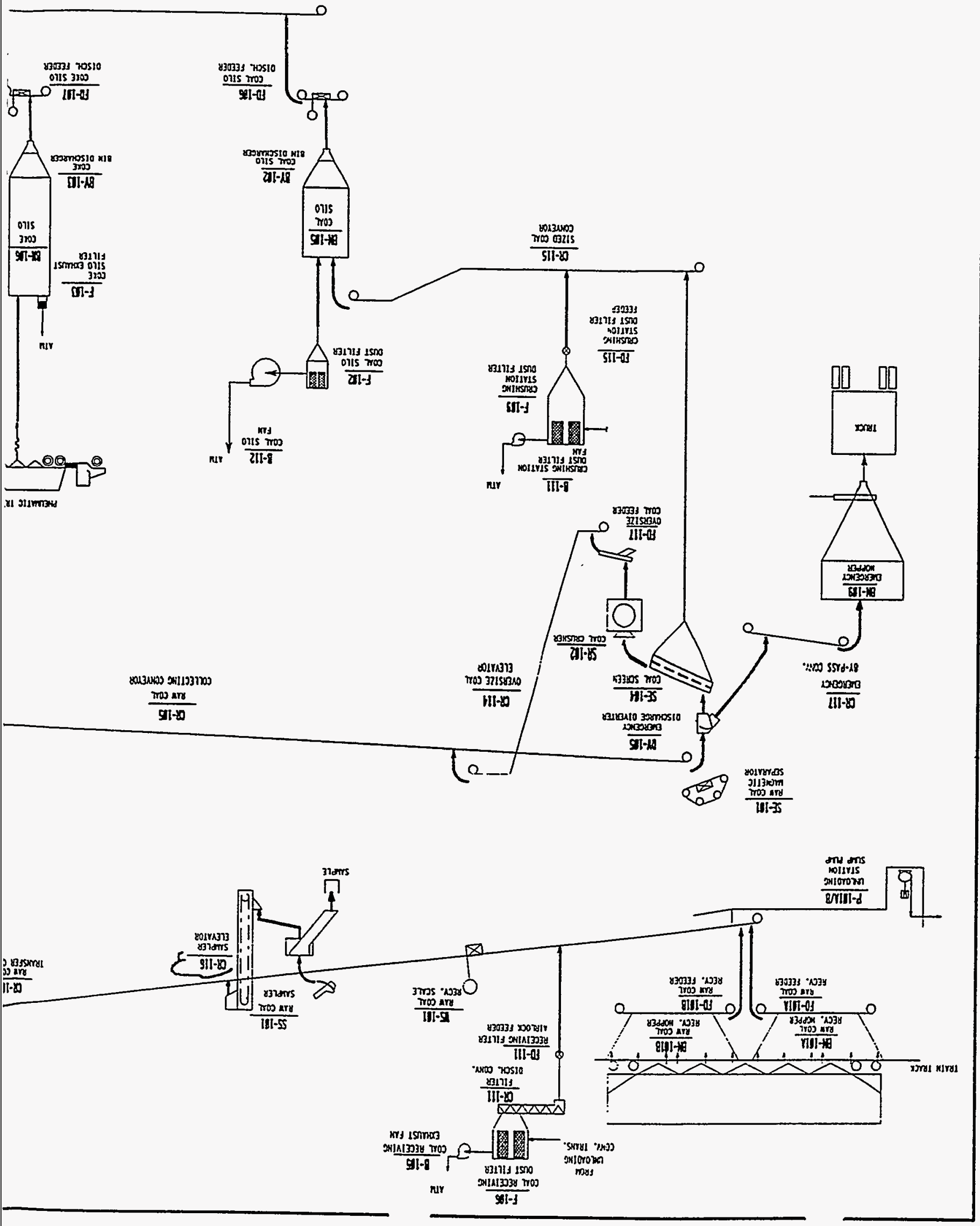




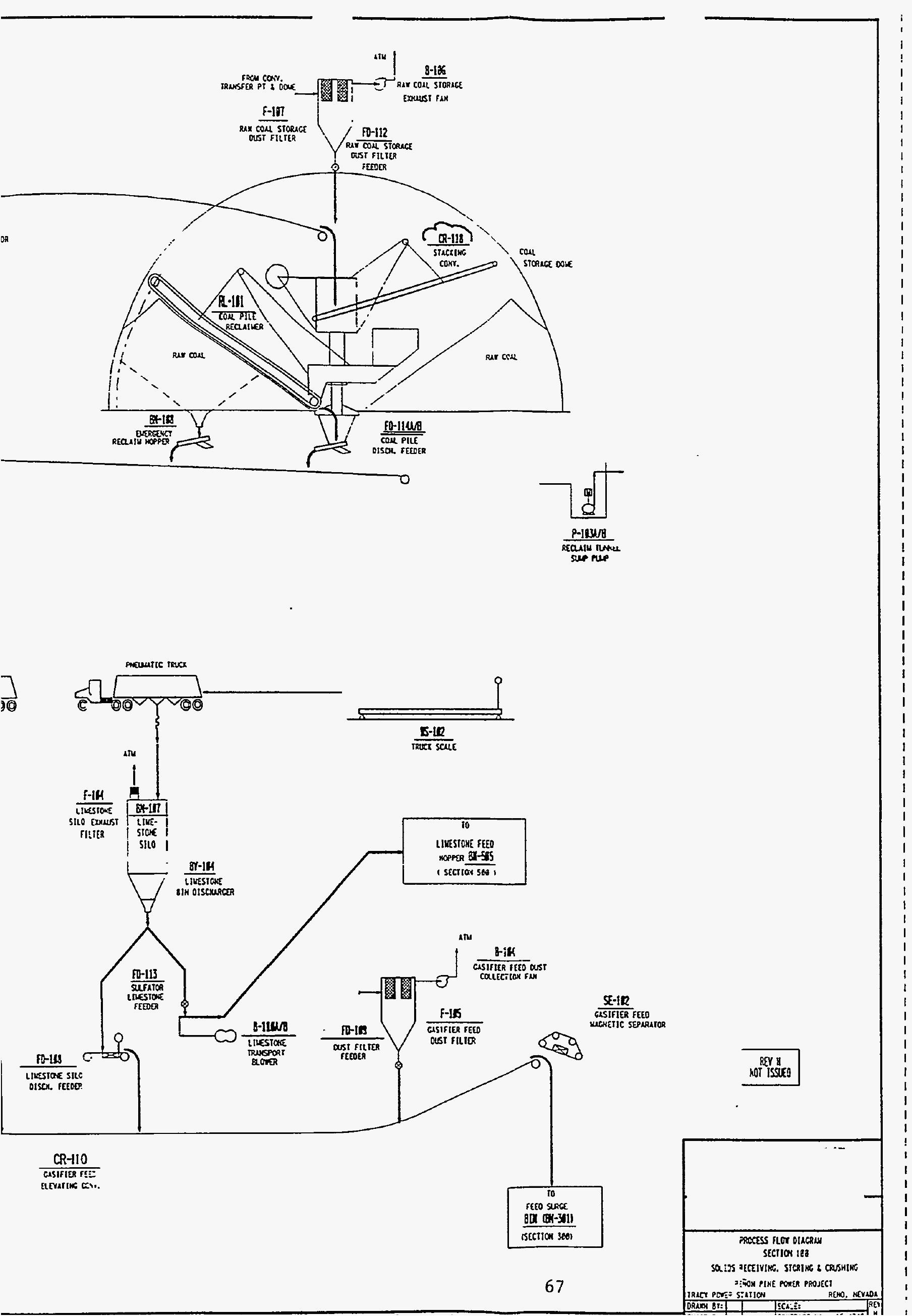




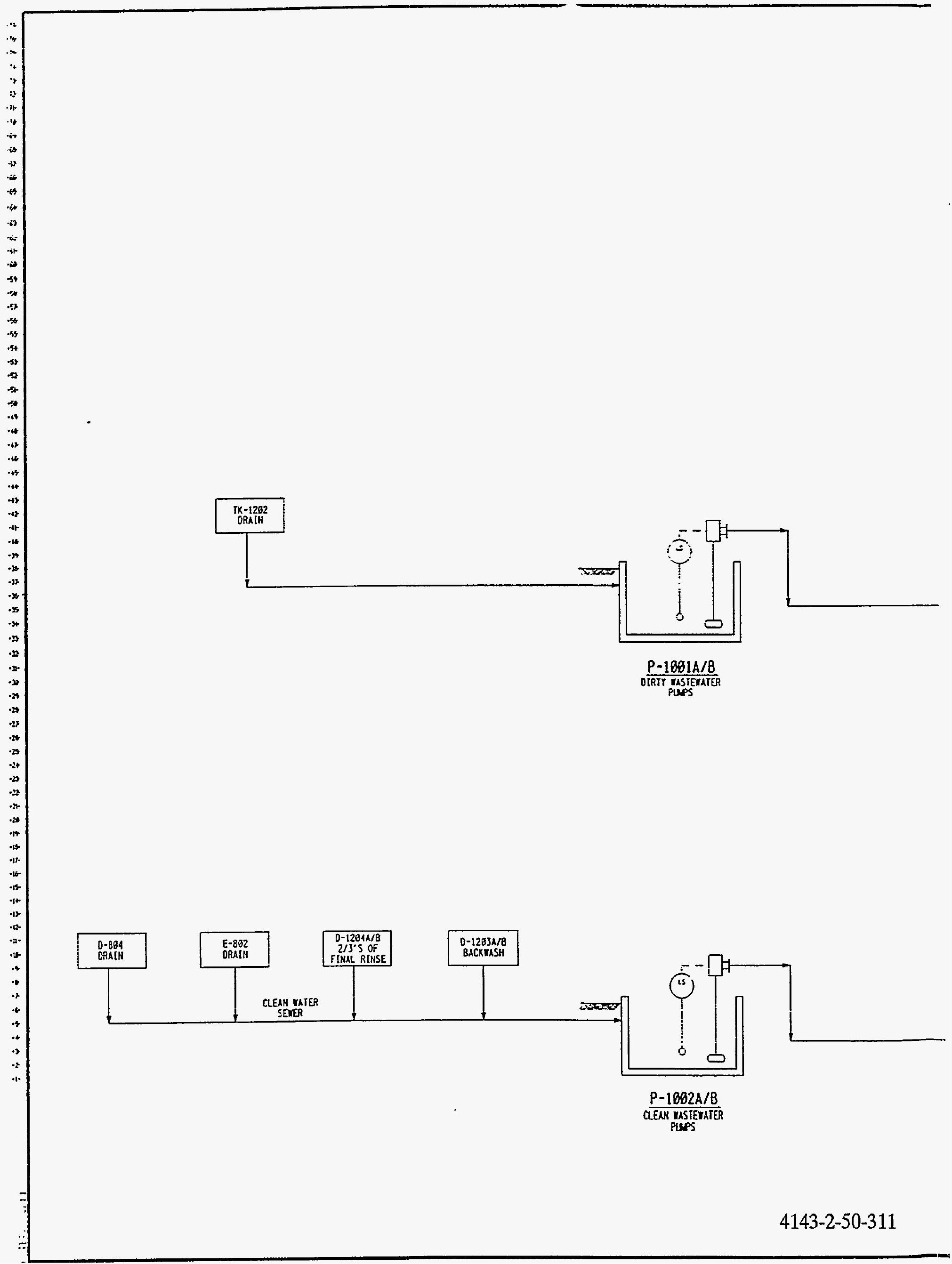




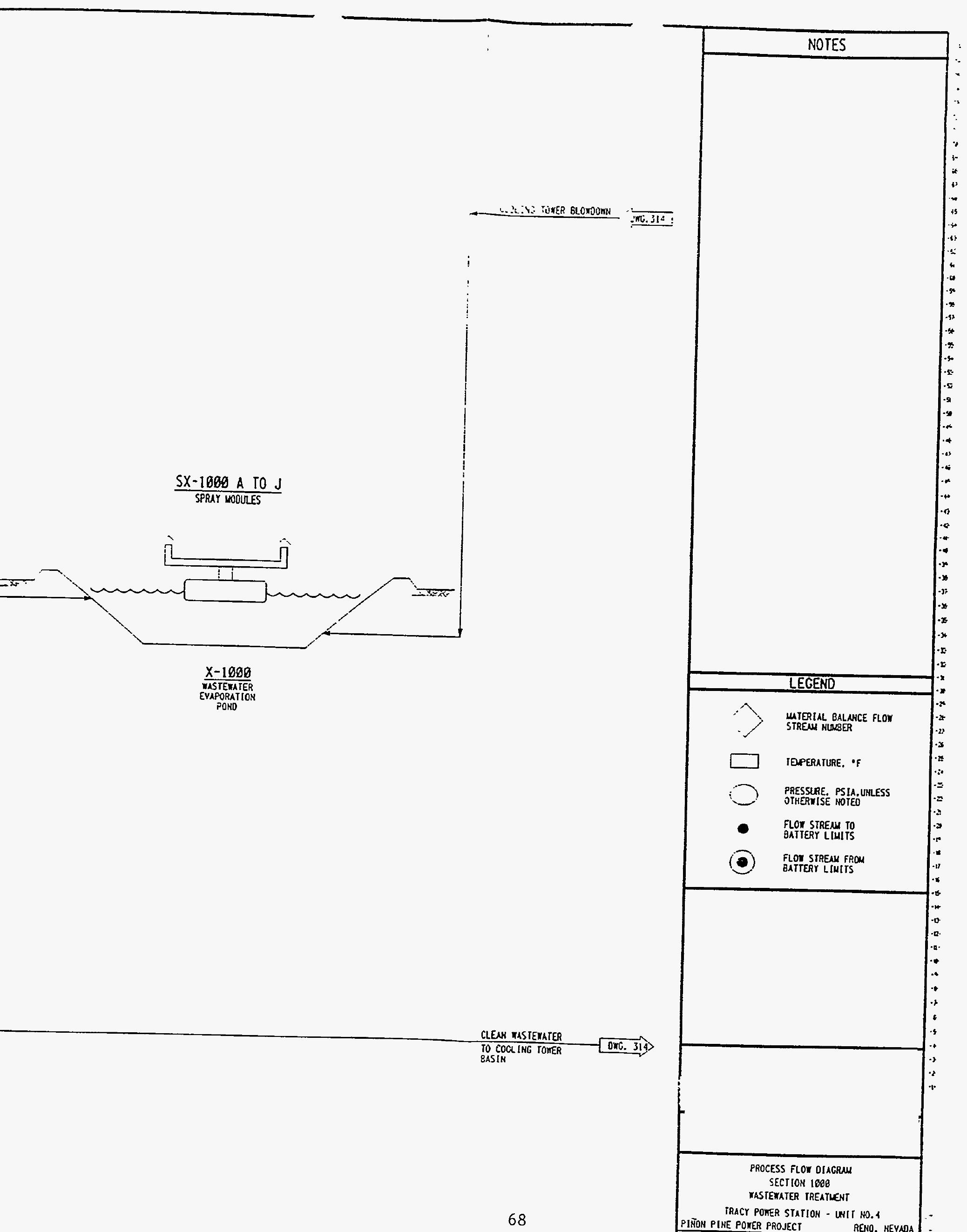




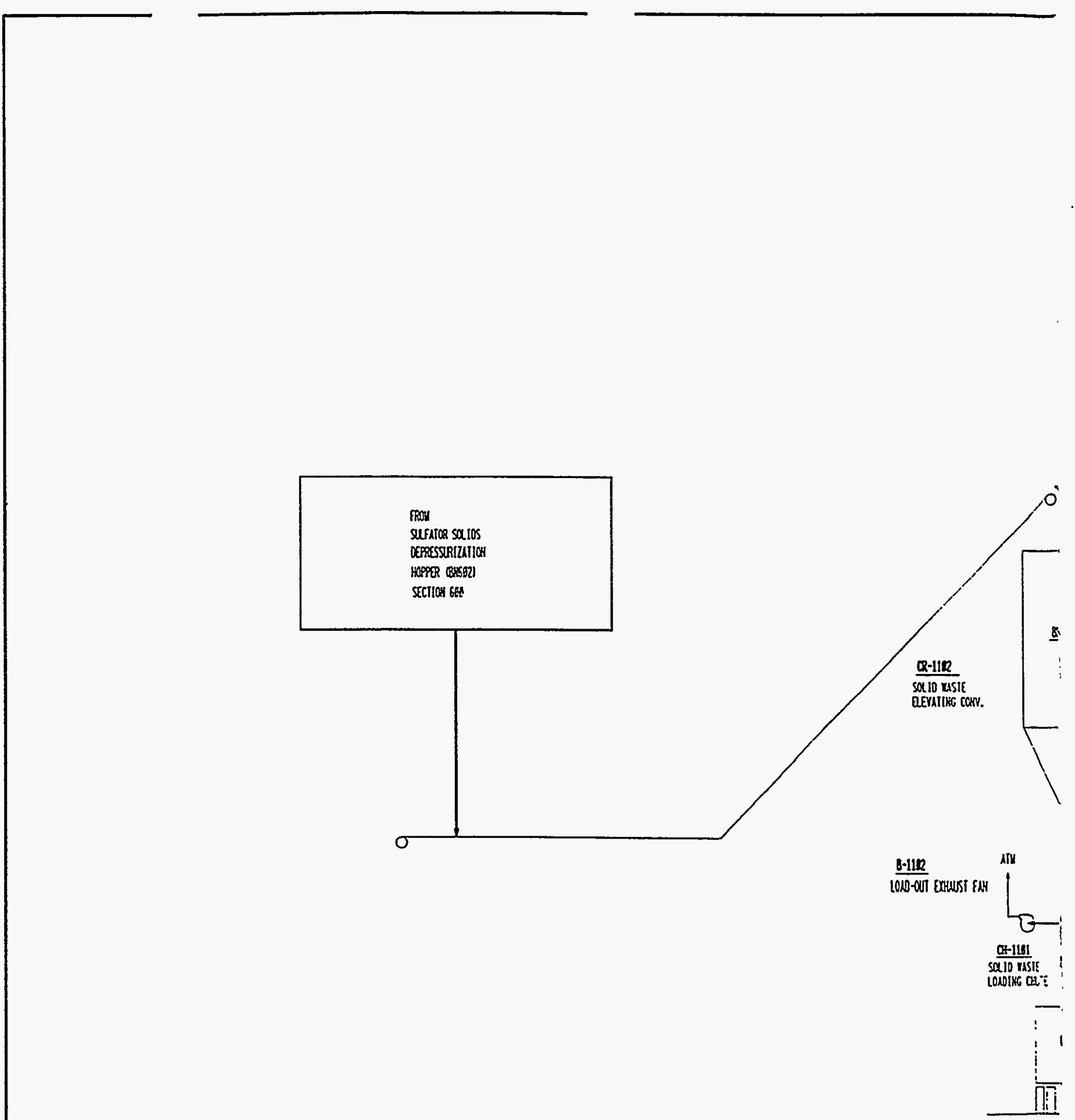

Surator saics

Depresslitalio

1000-0UT Extarst हn 


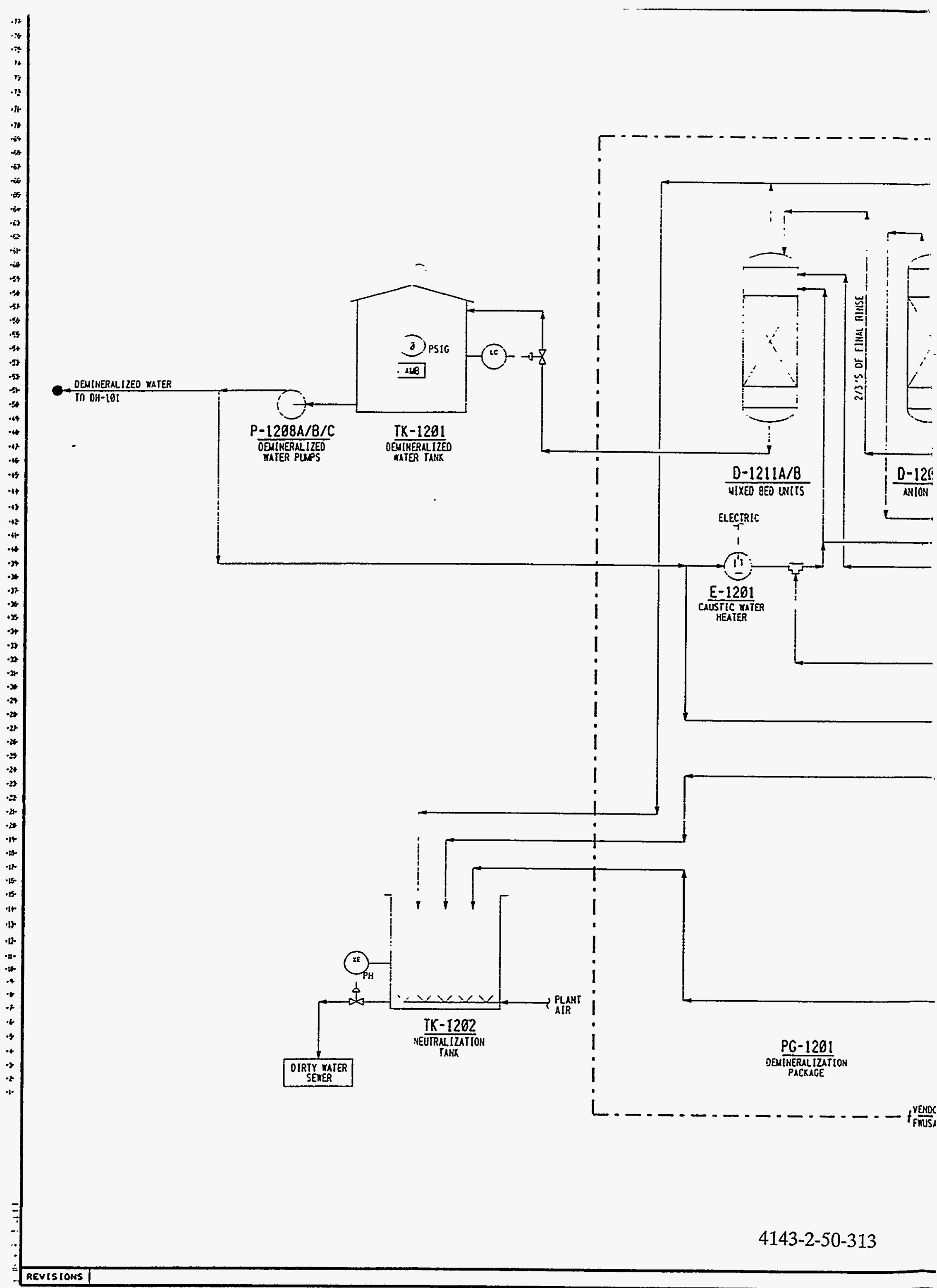




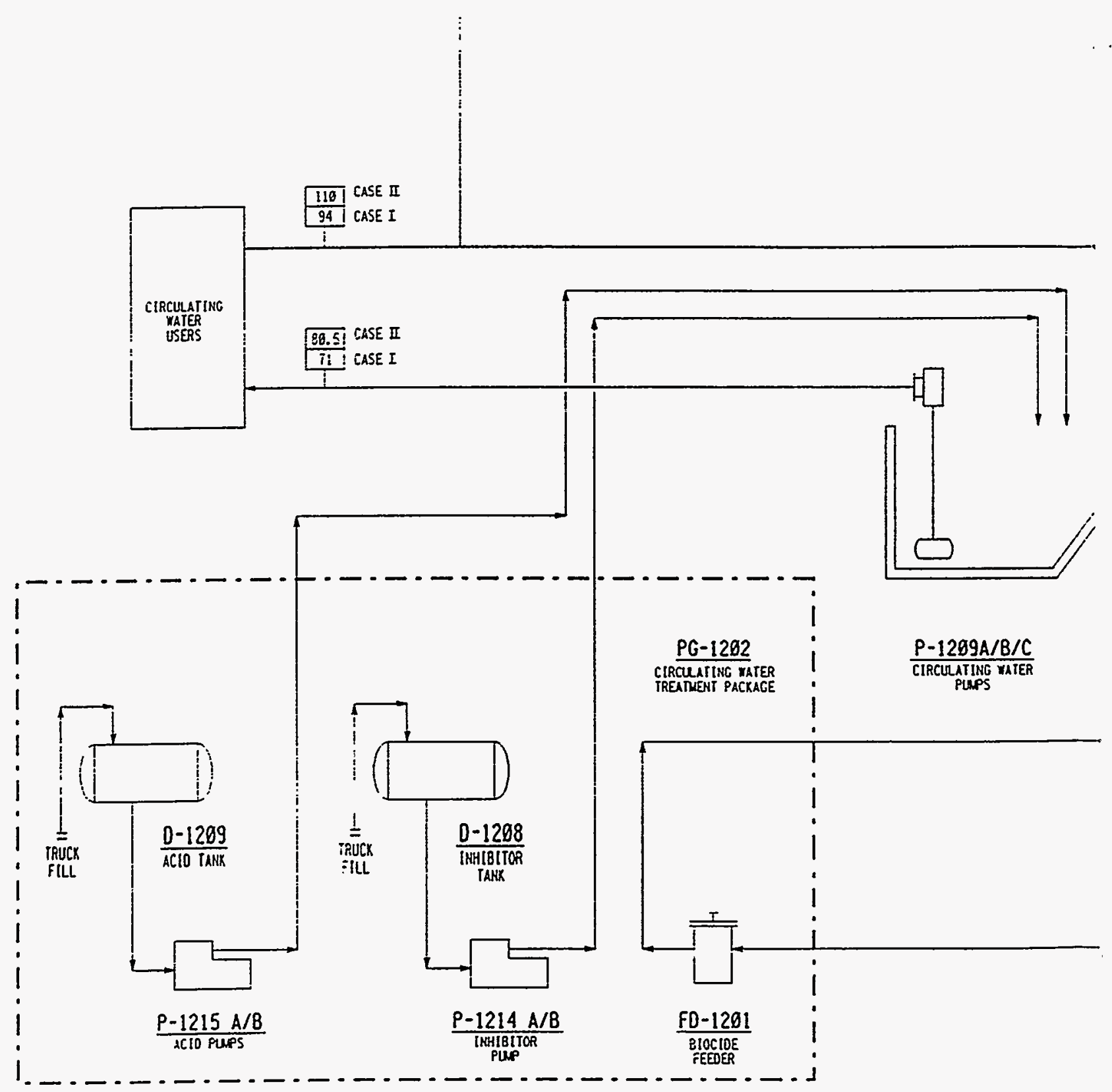




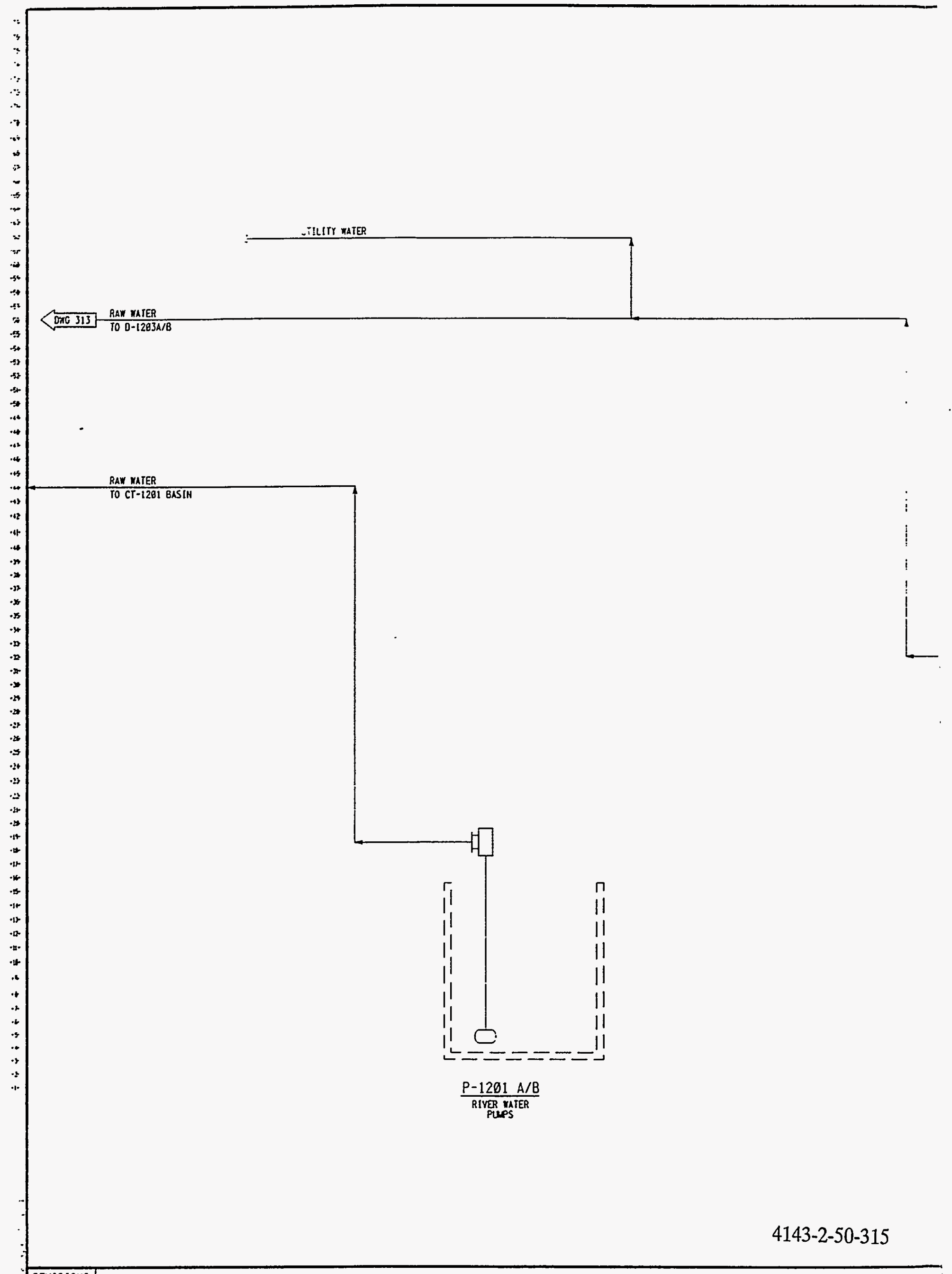


WELL TATER

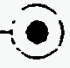

ExISIING NELLEI
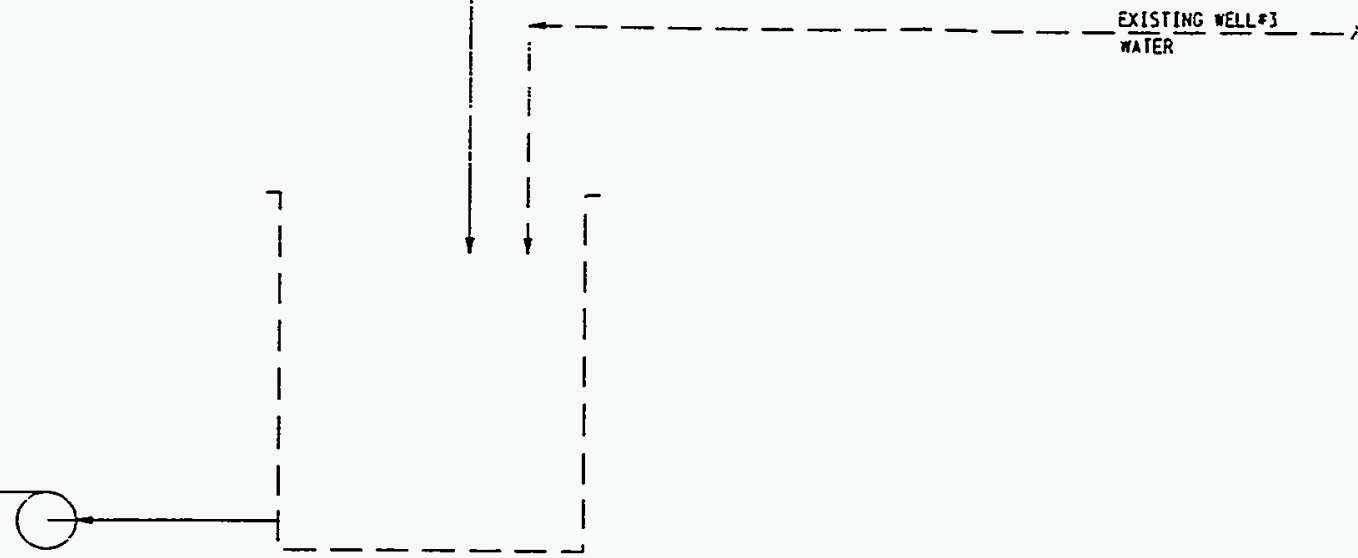

$\mathrm{P}-1292 \mathrm{~A} / \mathrm{B}$

RAF MAIE?

EXISTING KELL KATER TANX

LEGEND

MATERLAL BALANCE FLOT STREAH HLOBER

TEMPERATURE. •F

PRESSURE, PSIA, URLESS OTHERMISE NOTEO

FLOW STREA TO BAITERY LIMITS

(2) Flor STREAN Fro BATTERY LIHITS

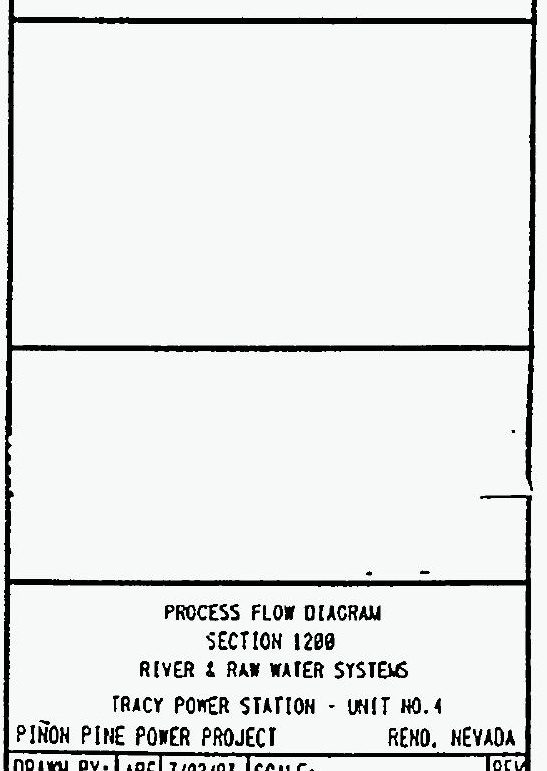




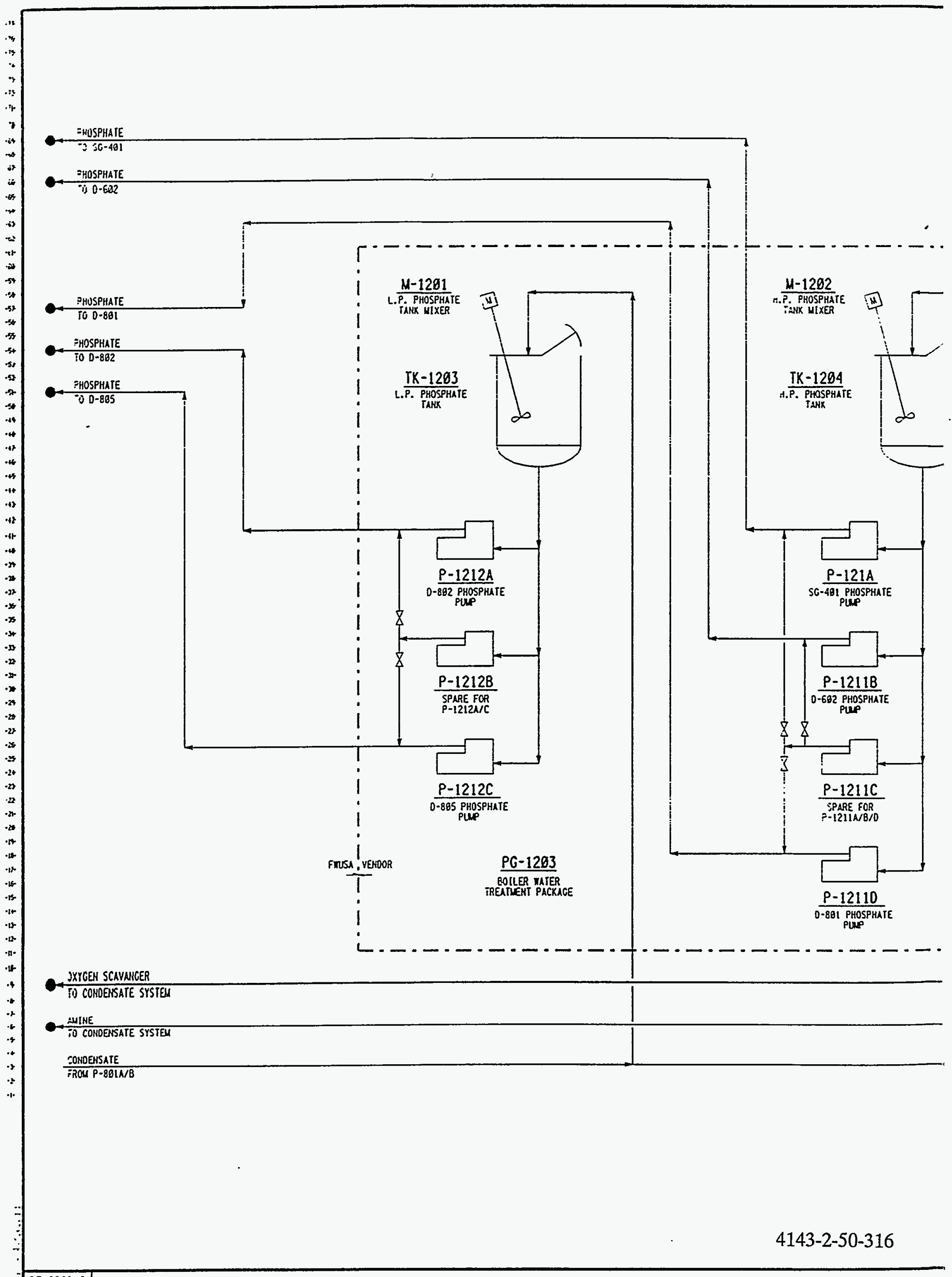




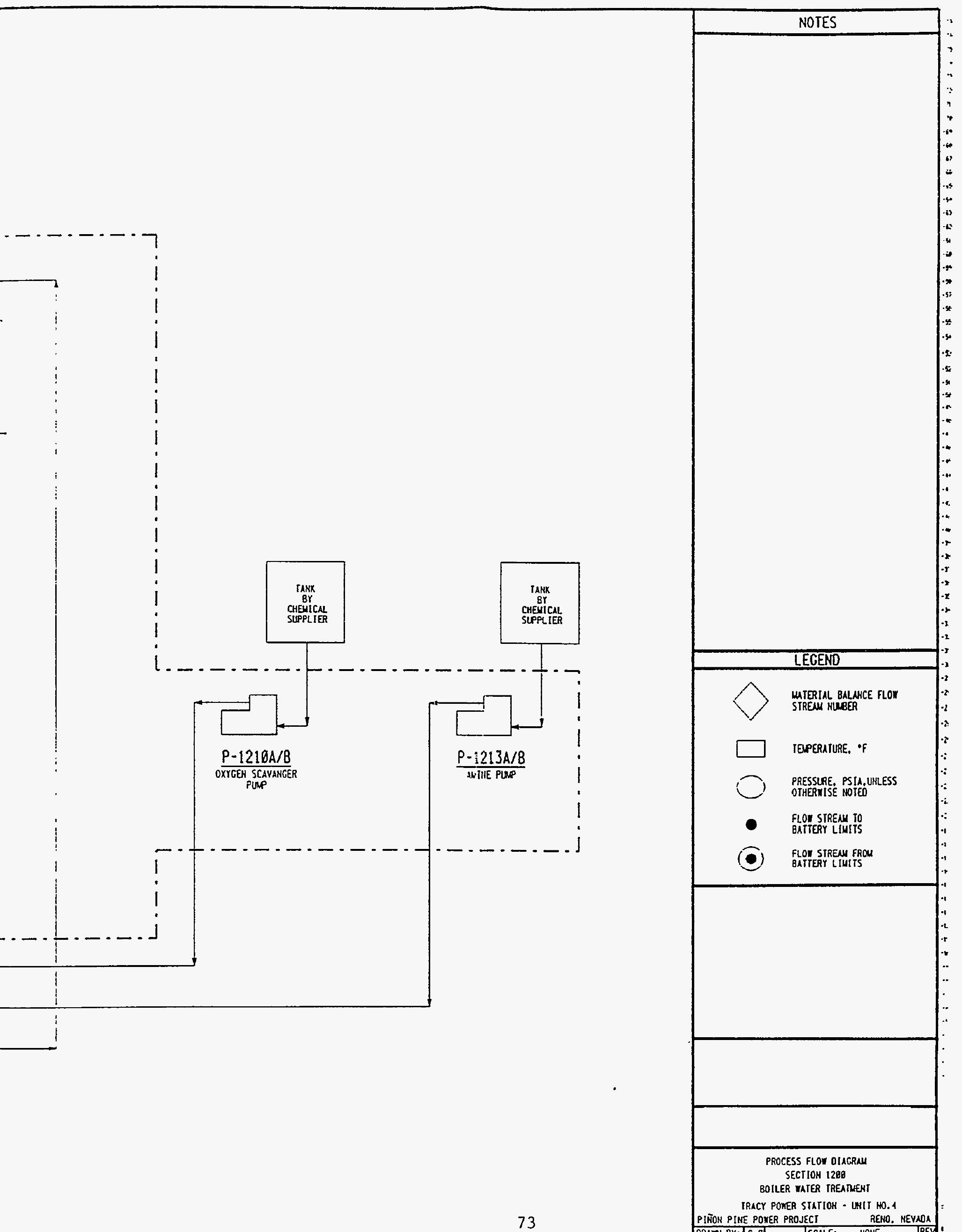




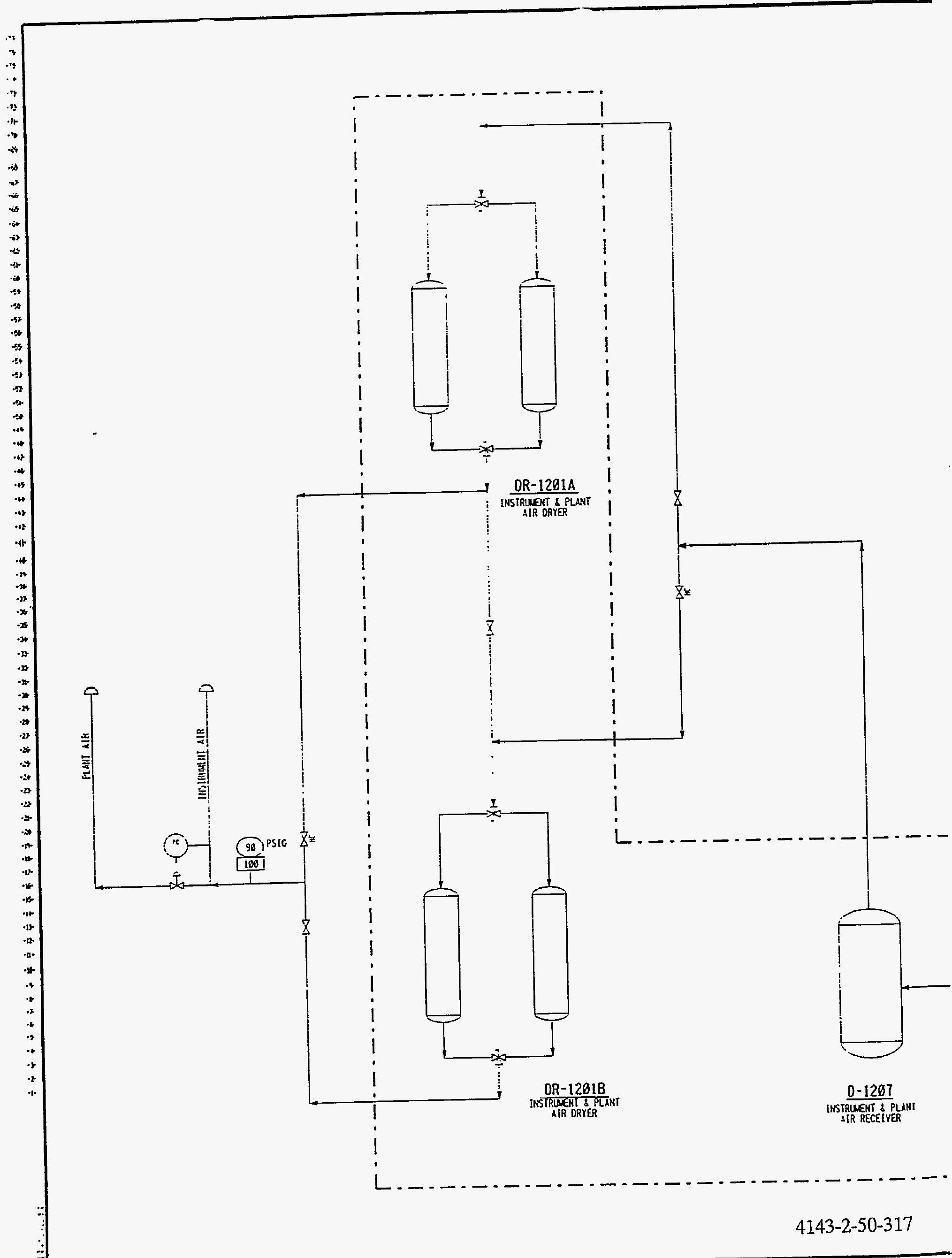




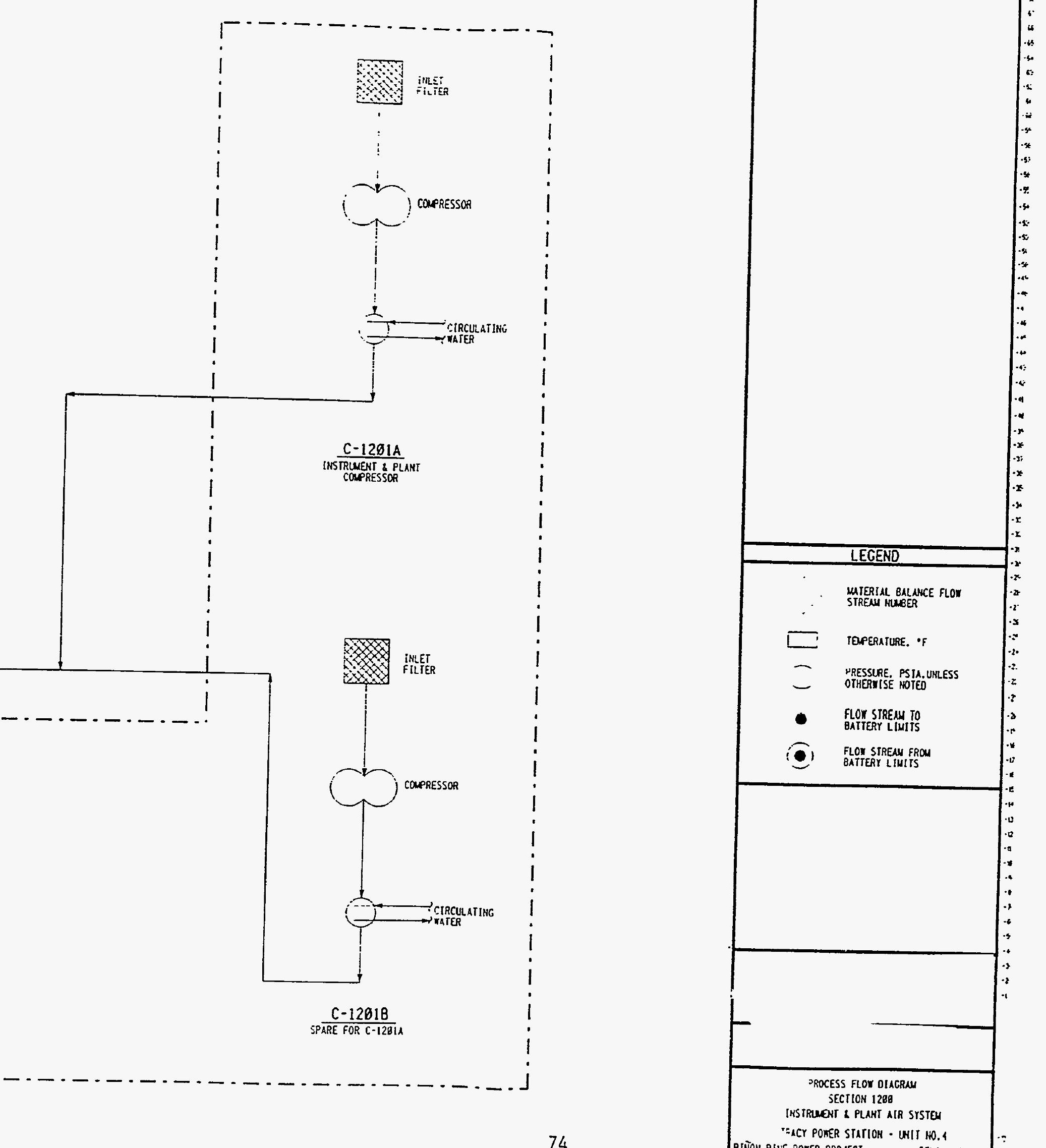




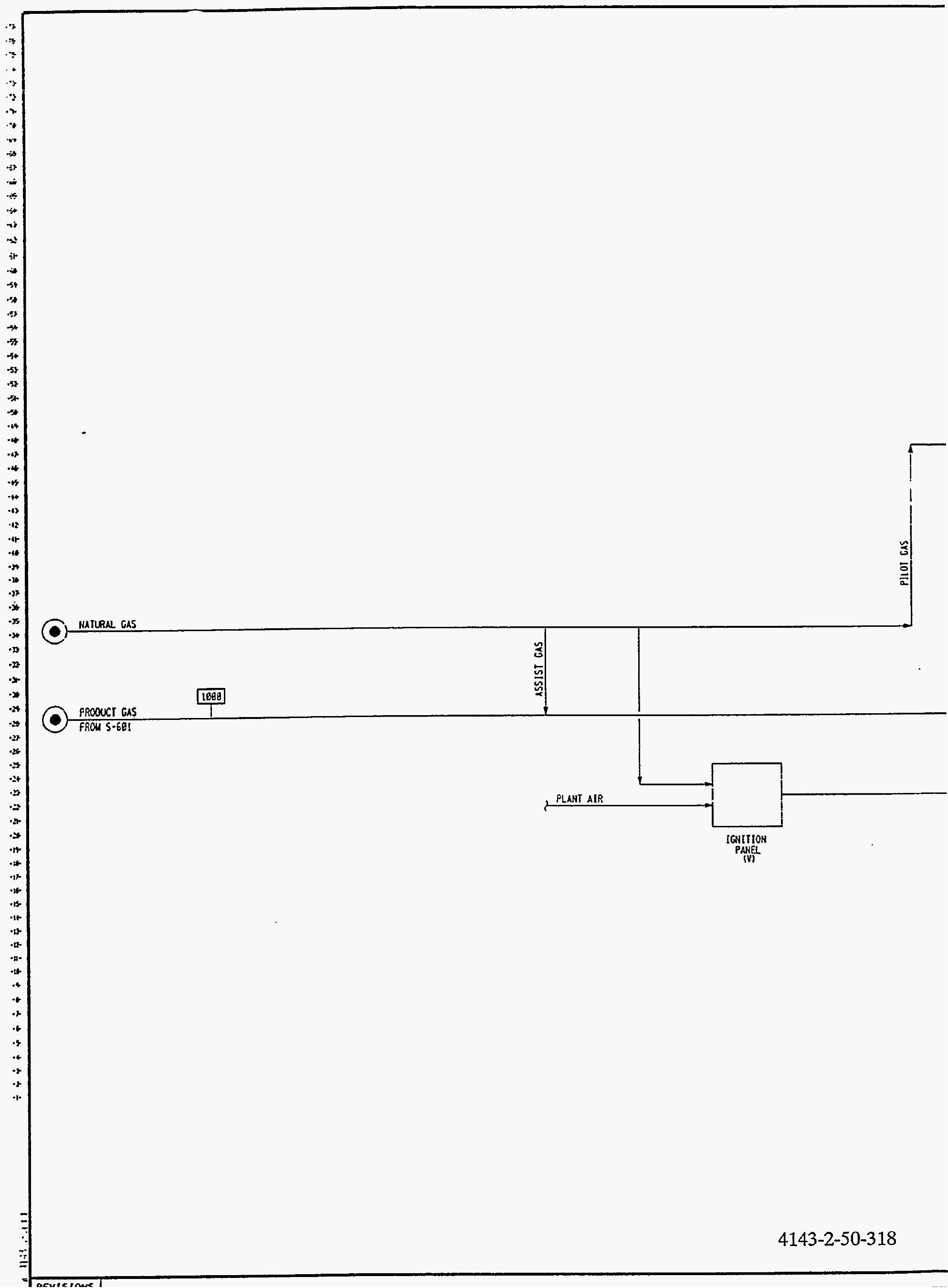




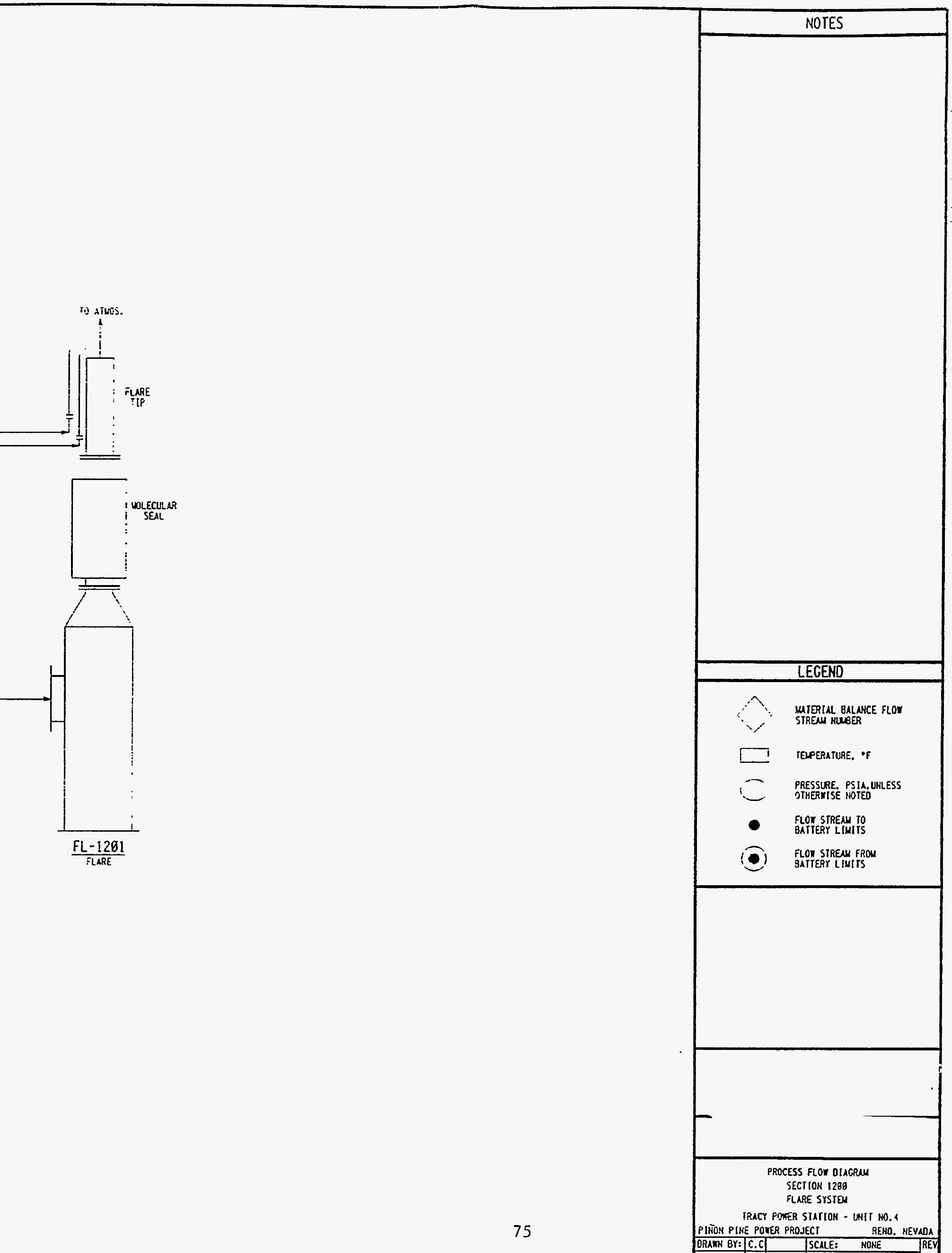




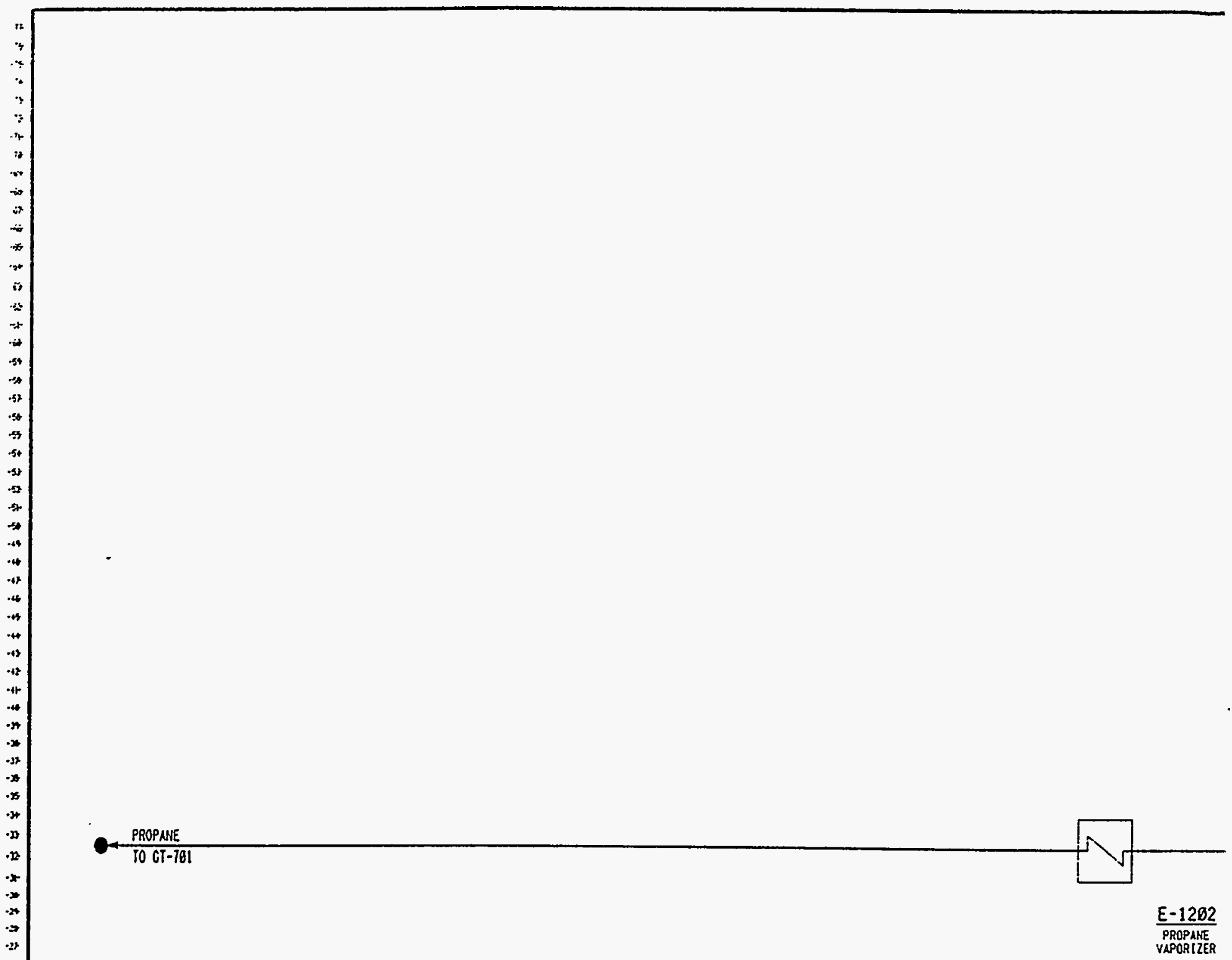




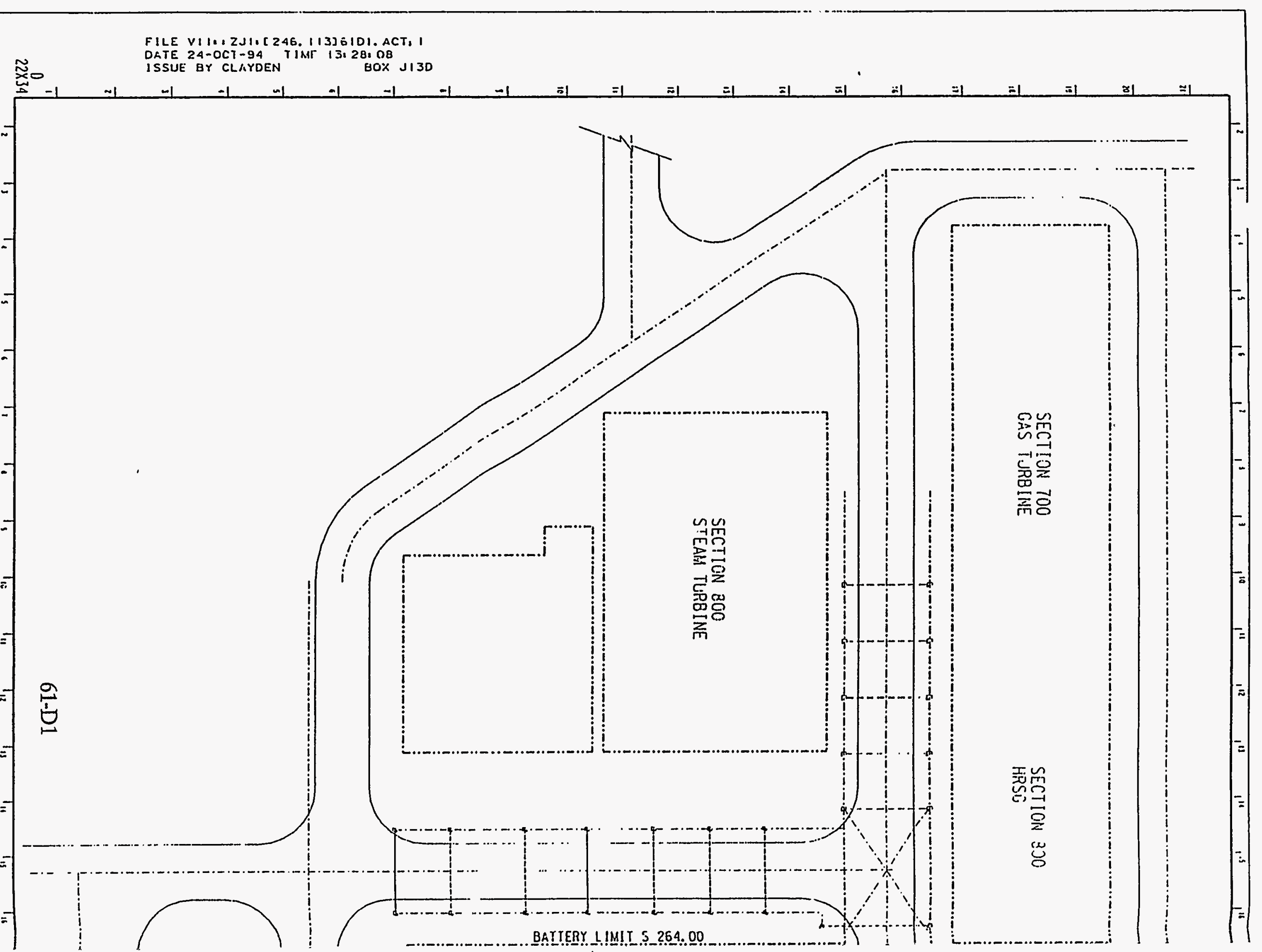




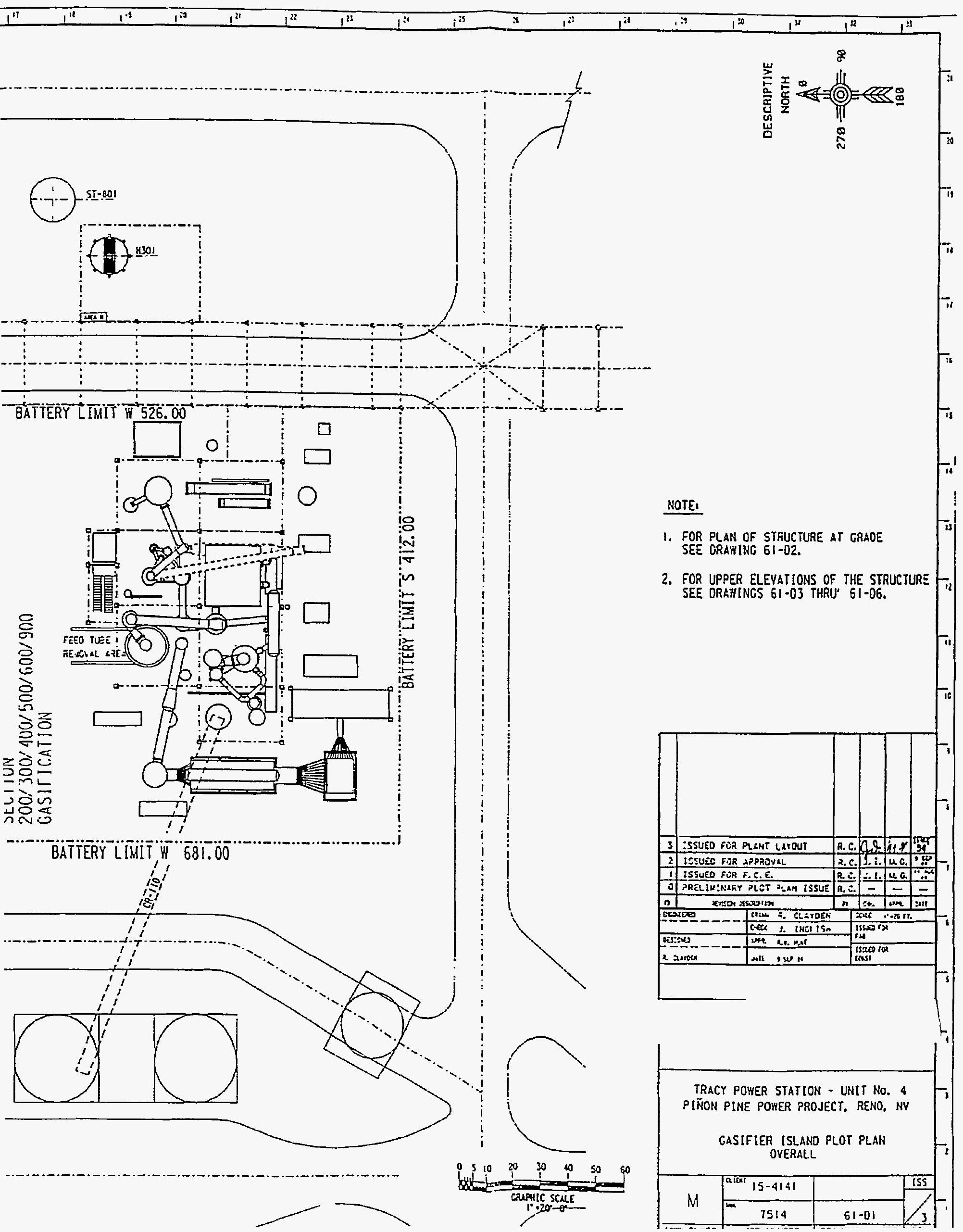




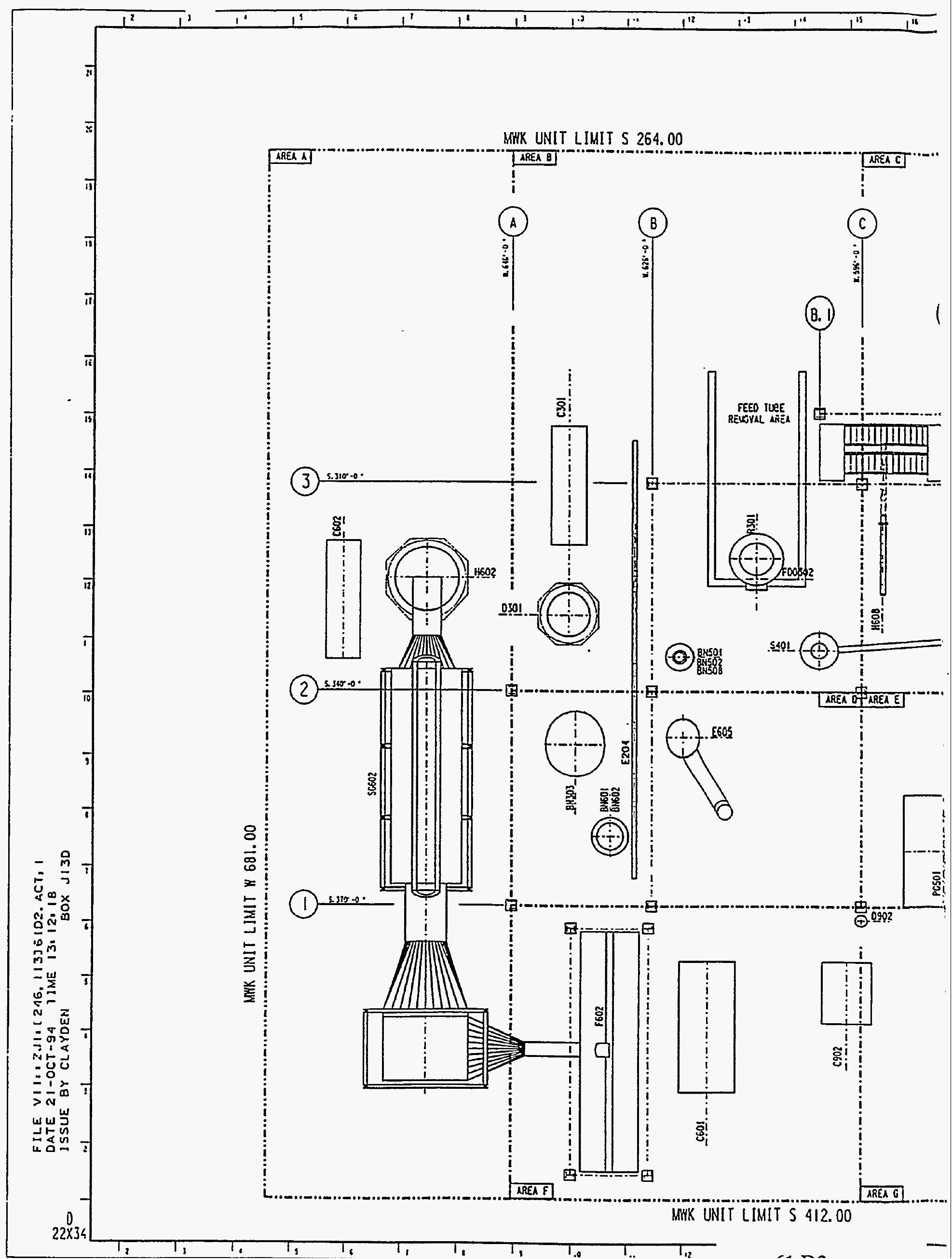




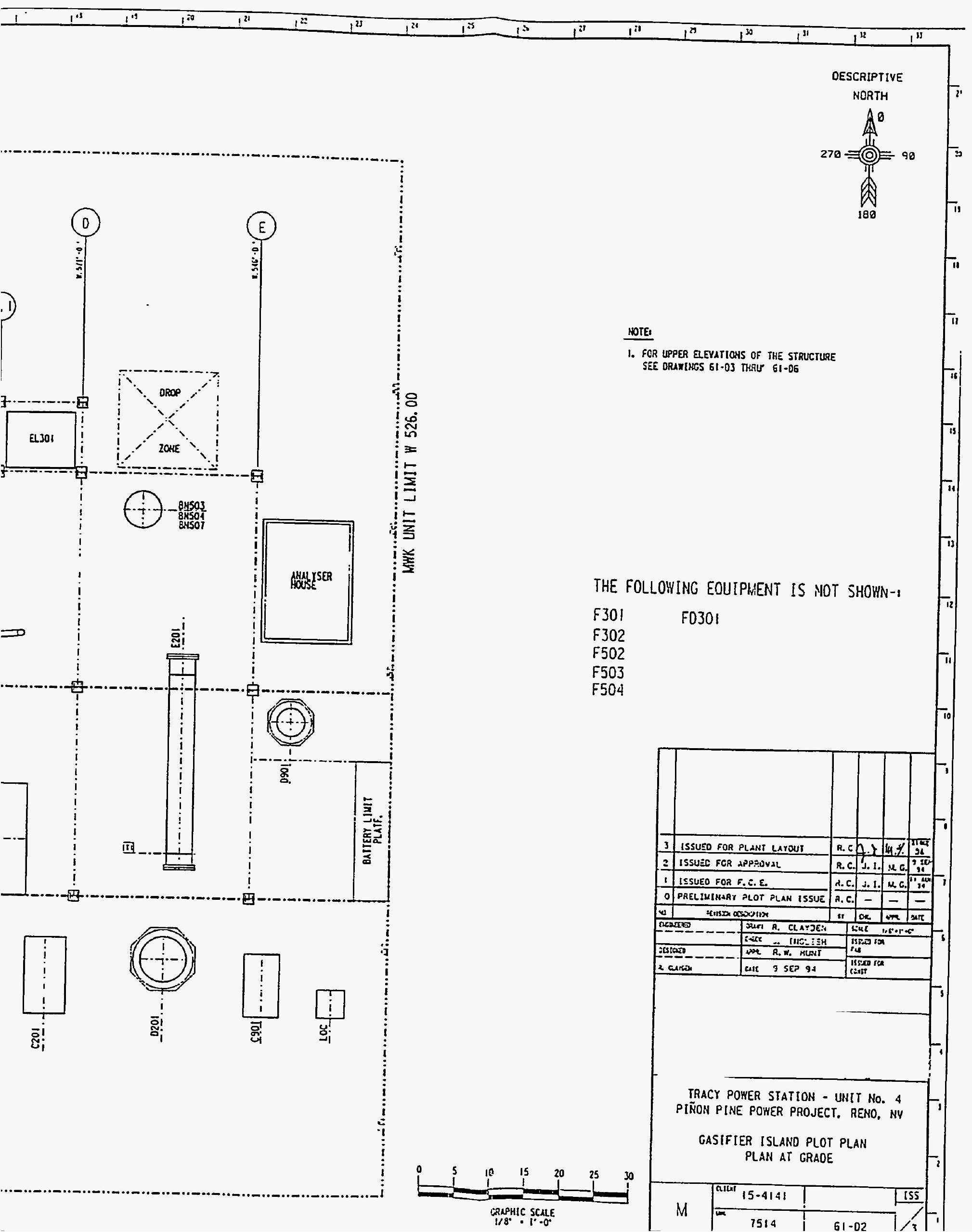




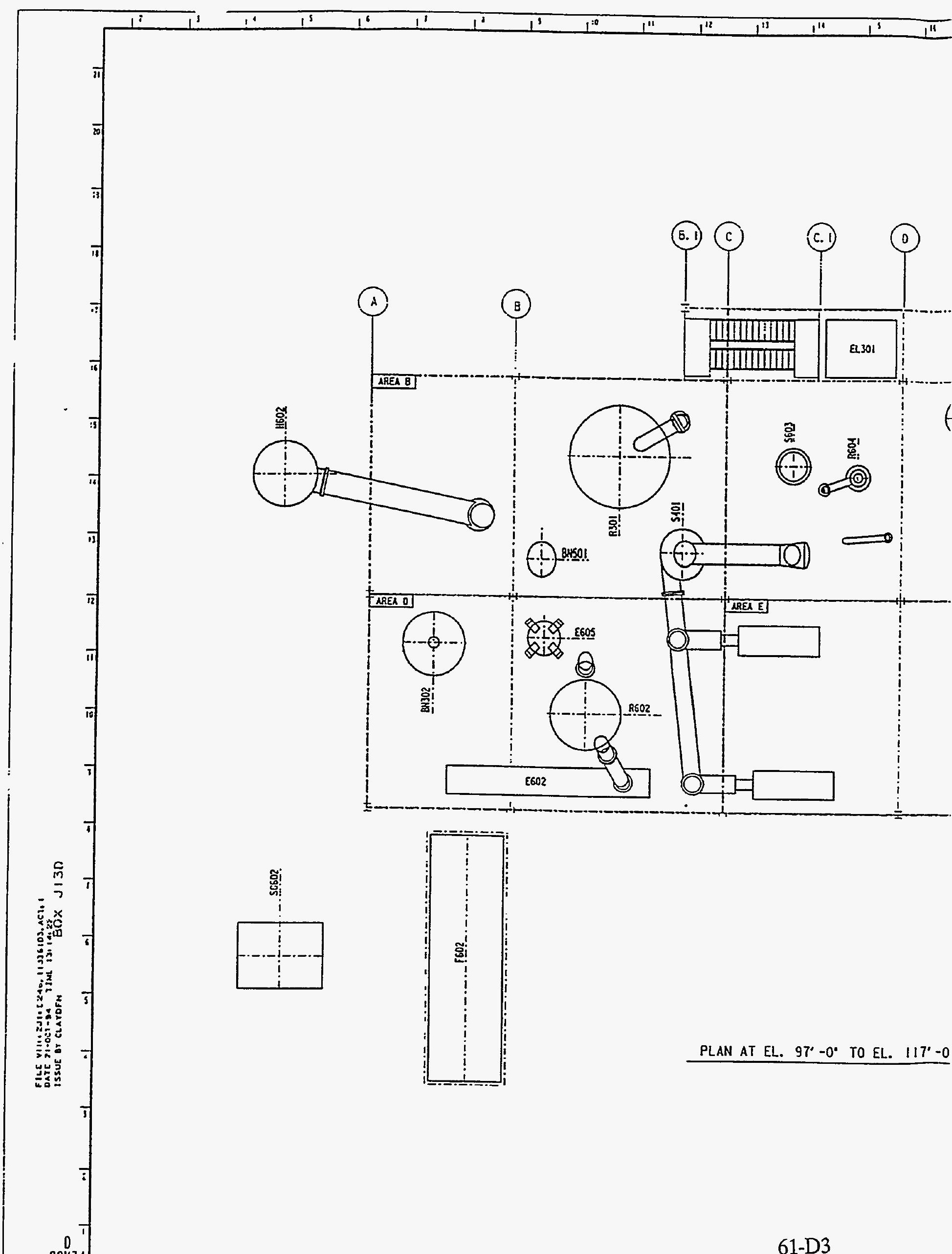




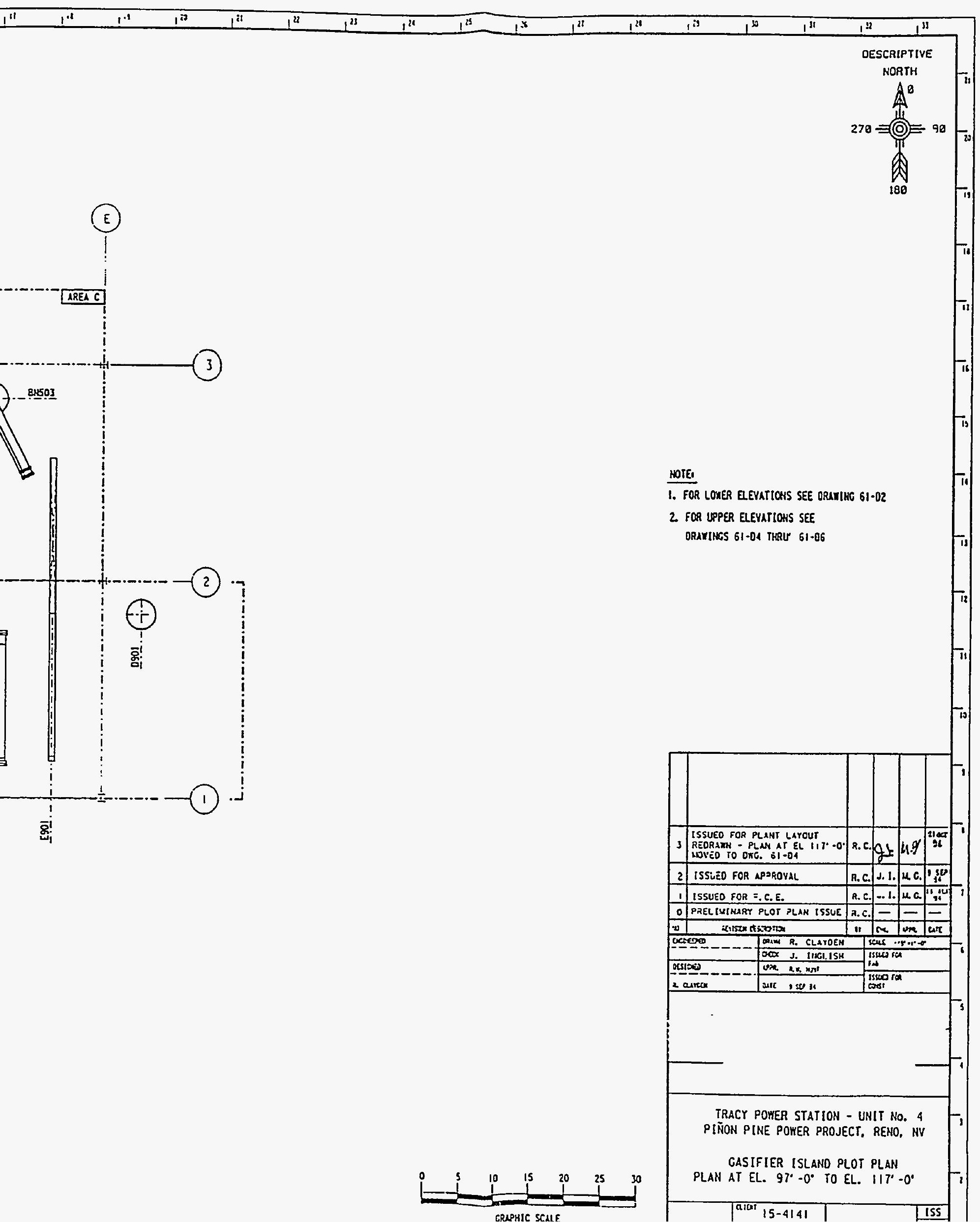




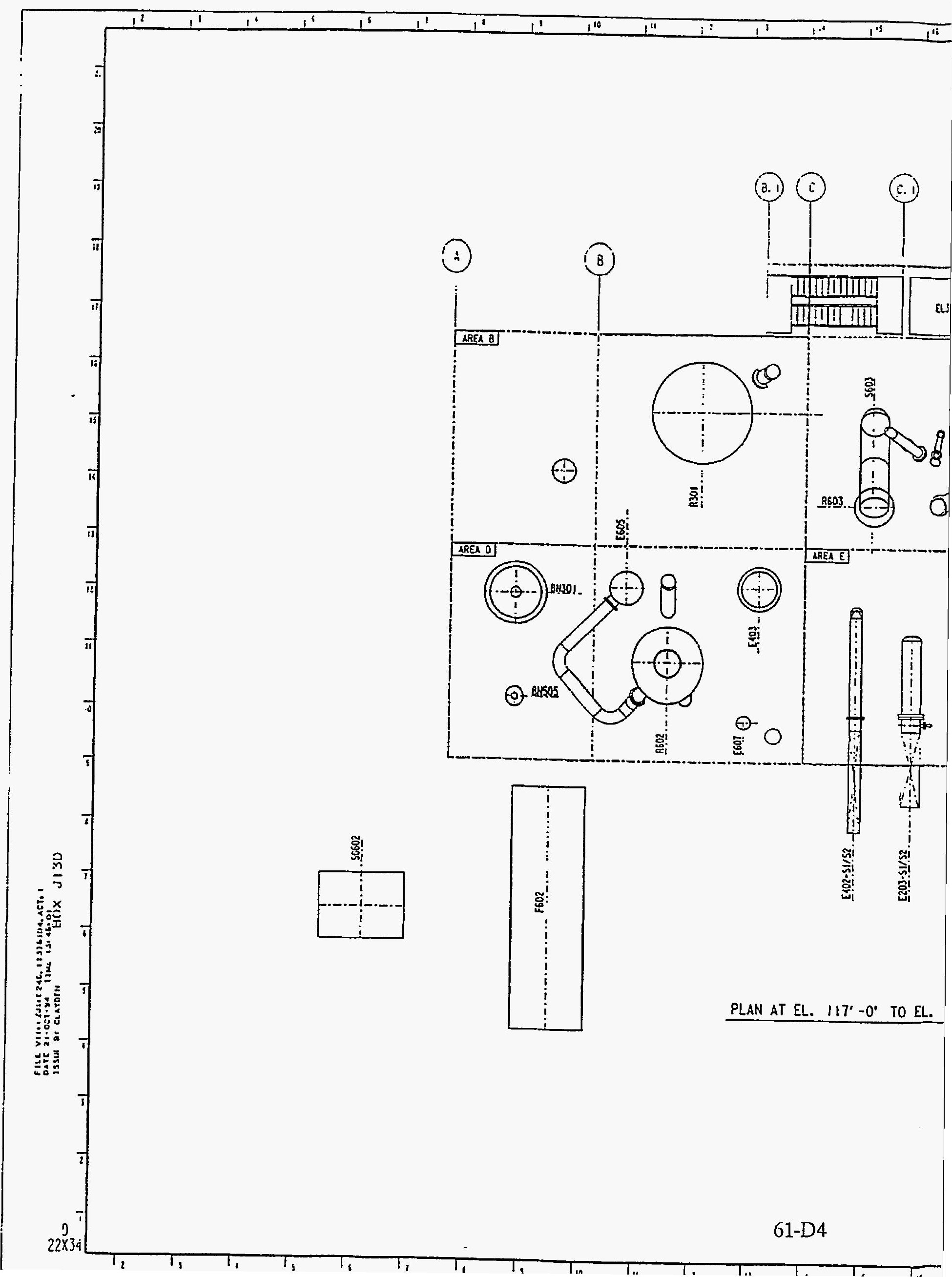




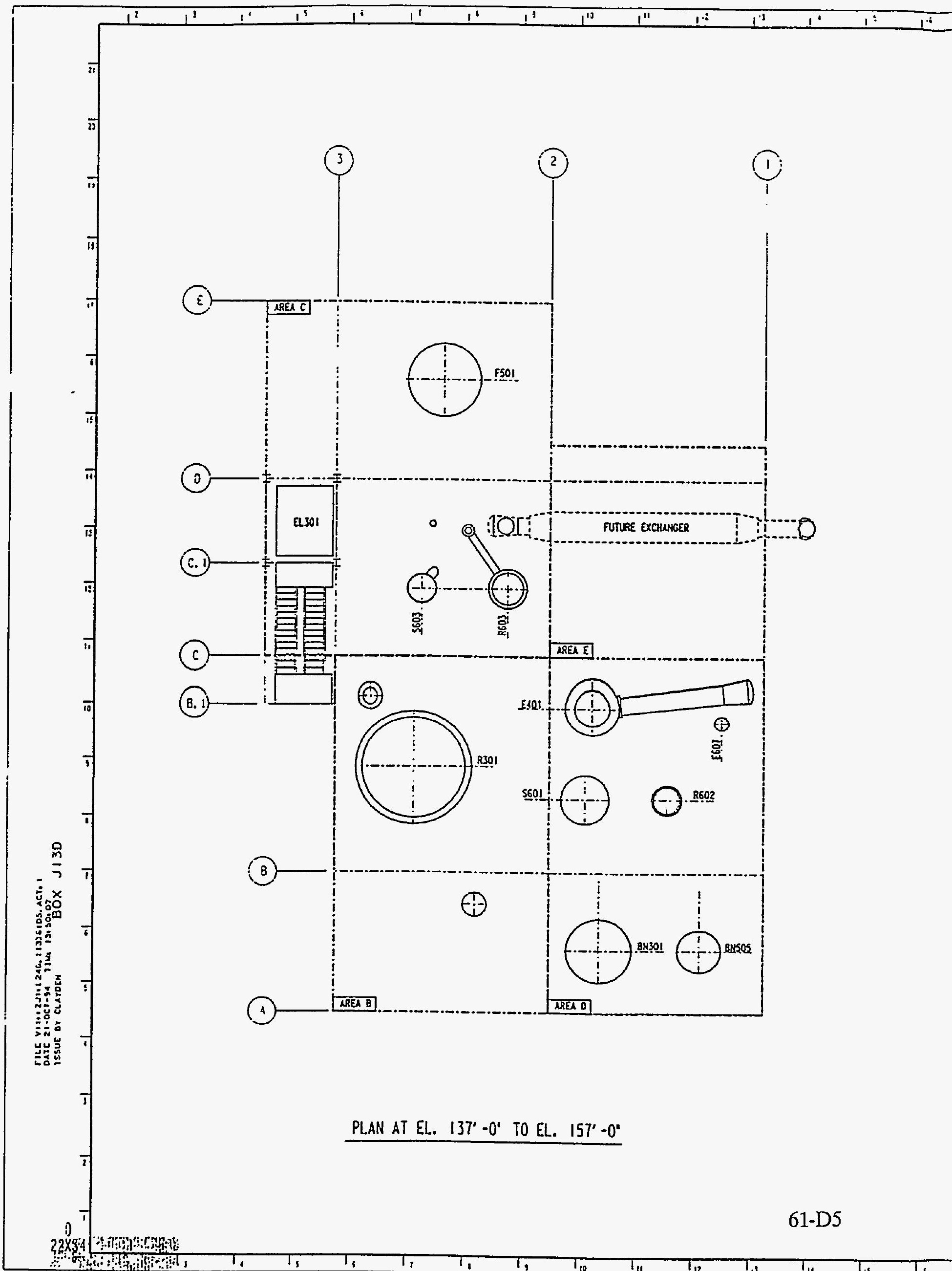




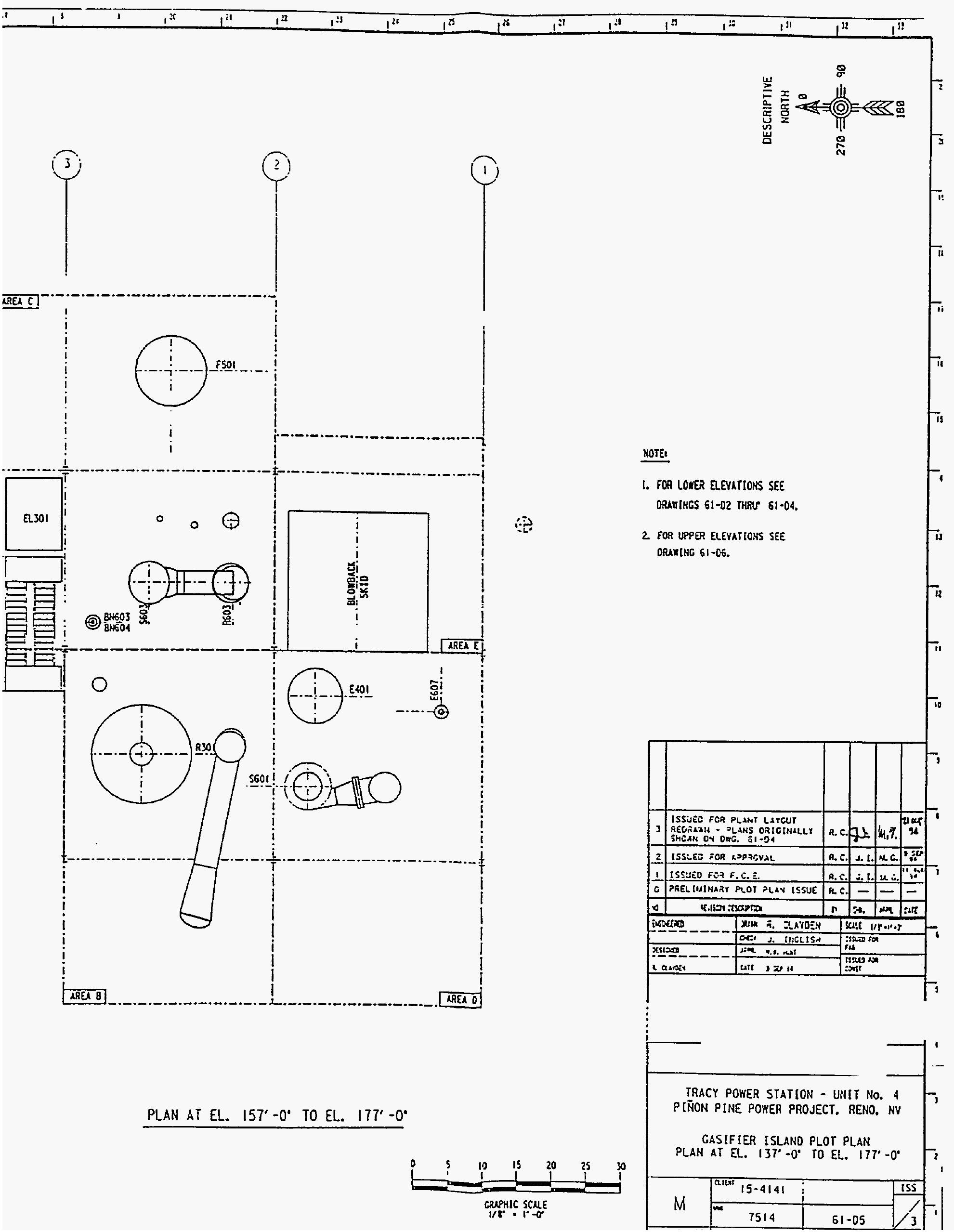




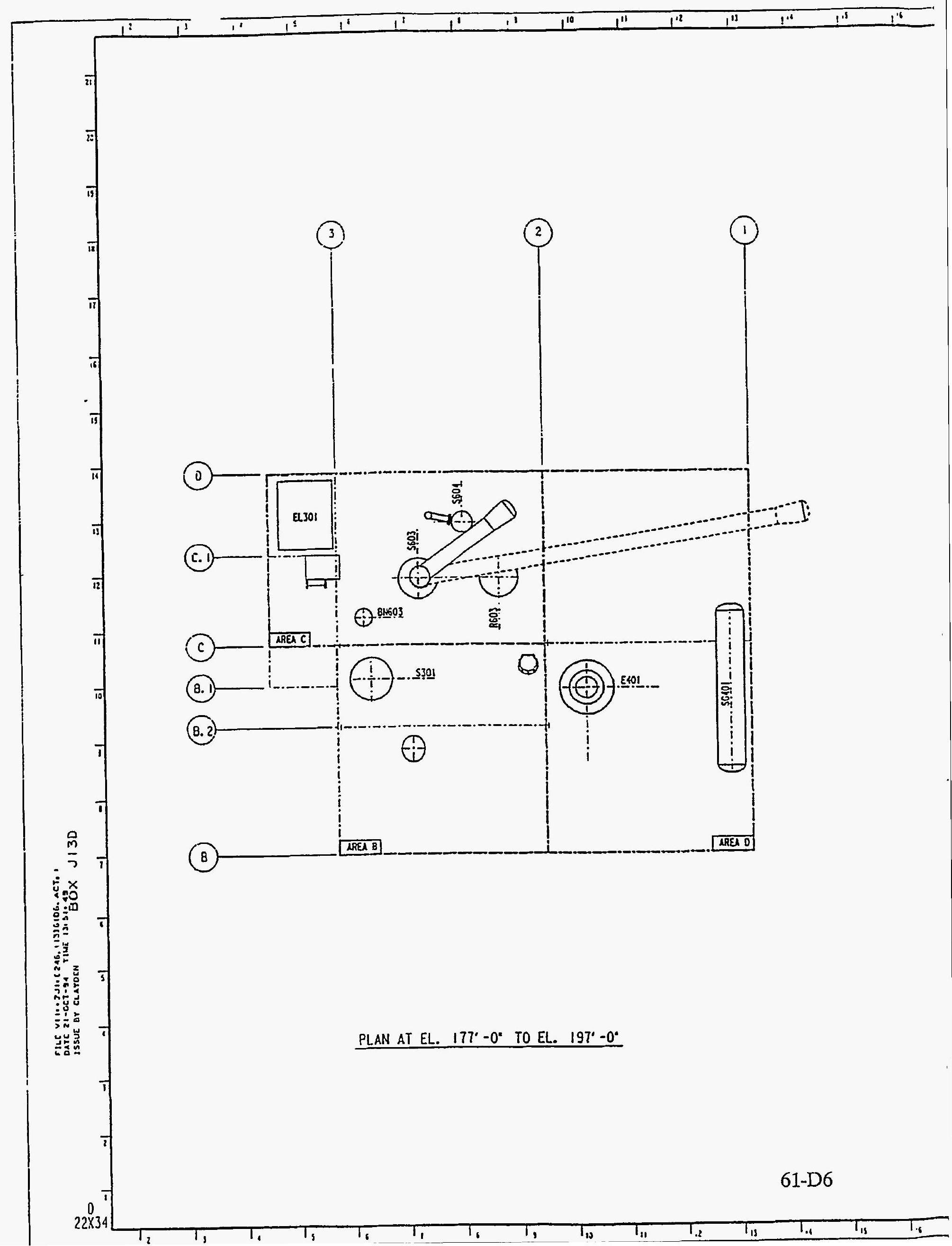




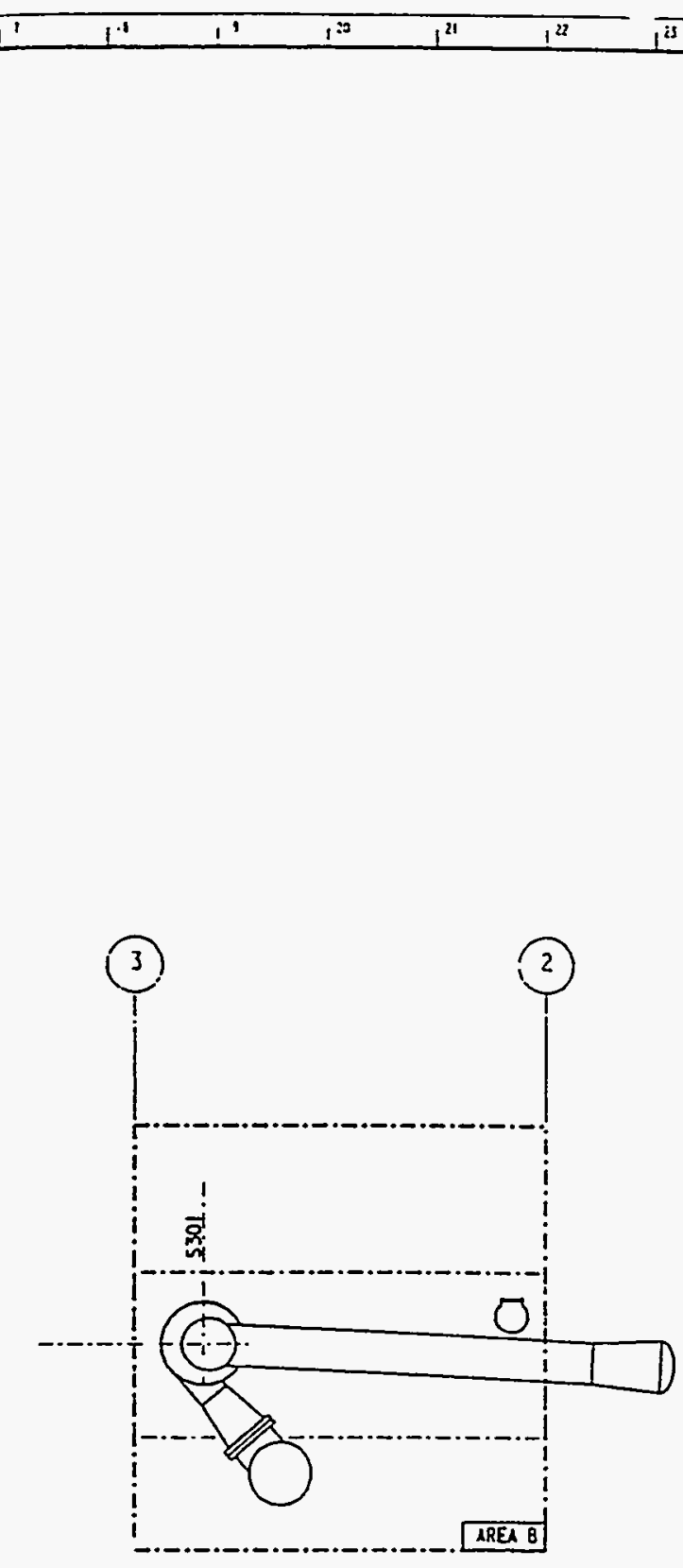

MOTE:

I. FOR LOMER ELEYTIOASS SEE ORAXIHES 61-02 THRUY $61-05$.
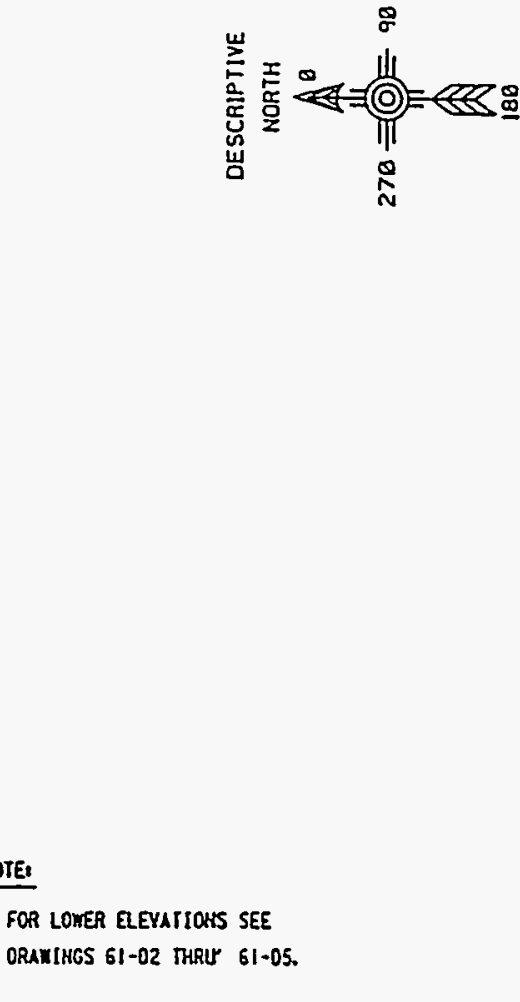

PLAN AT EL. $197^{\circ}-0^{\circ}$ AND ABOVE

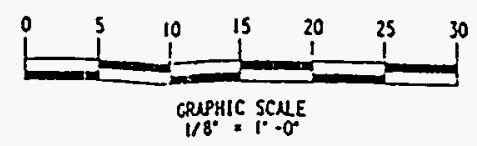

TRACY POHER STATION - UNIT NO. 4 PIÑON PINE POHER PROJECT. RENO, NY

GASIFIER ISLAND PLOT PLAN PLAN AT EL. $177^{\circ}-0^{\circ}$ and above

\begin{tabular}{|c|c|c|c|}
\hline \multirow{2}{*}{$M$} & aाta $15-4141$ & \\
\hline 100 & 7514 & $61-06$ & 155 \\
\hline
\end{tabular}




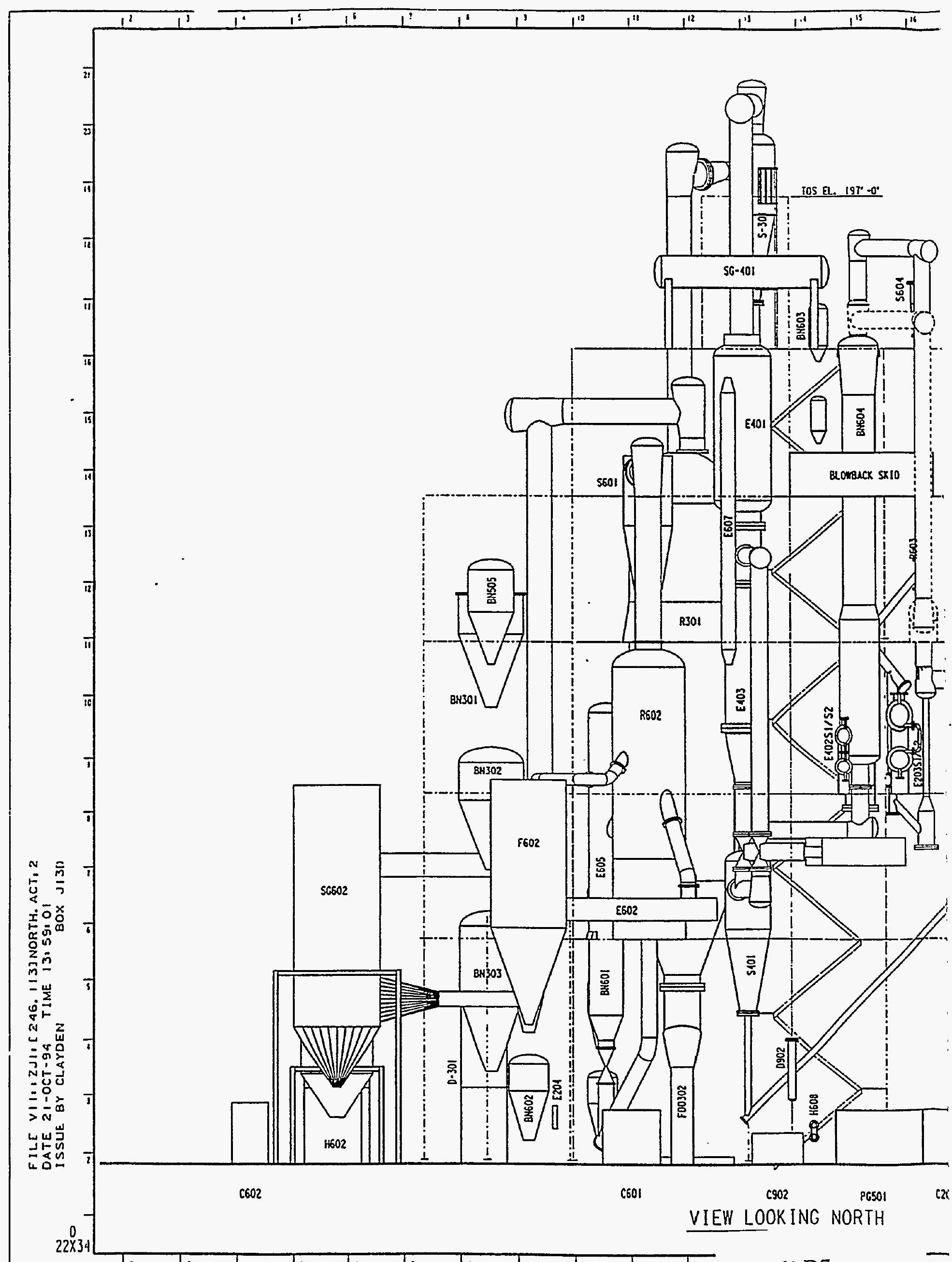


FILE VIIIZJIII 246,113$]$ EAST. ACT, I

DATE 21-OCT-94 TIME 14:15157

ISSUE BY CLAYDEN BOX JISD

స્રુ

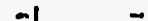

官

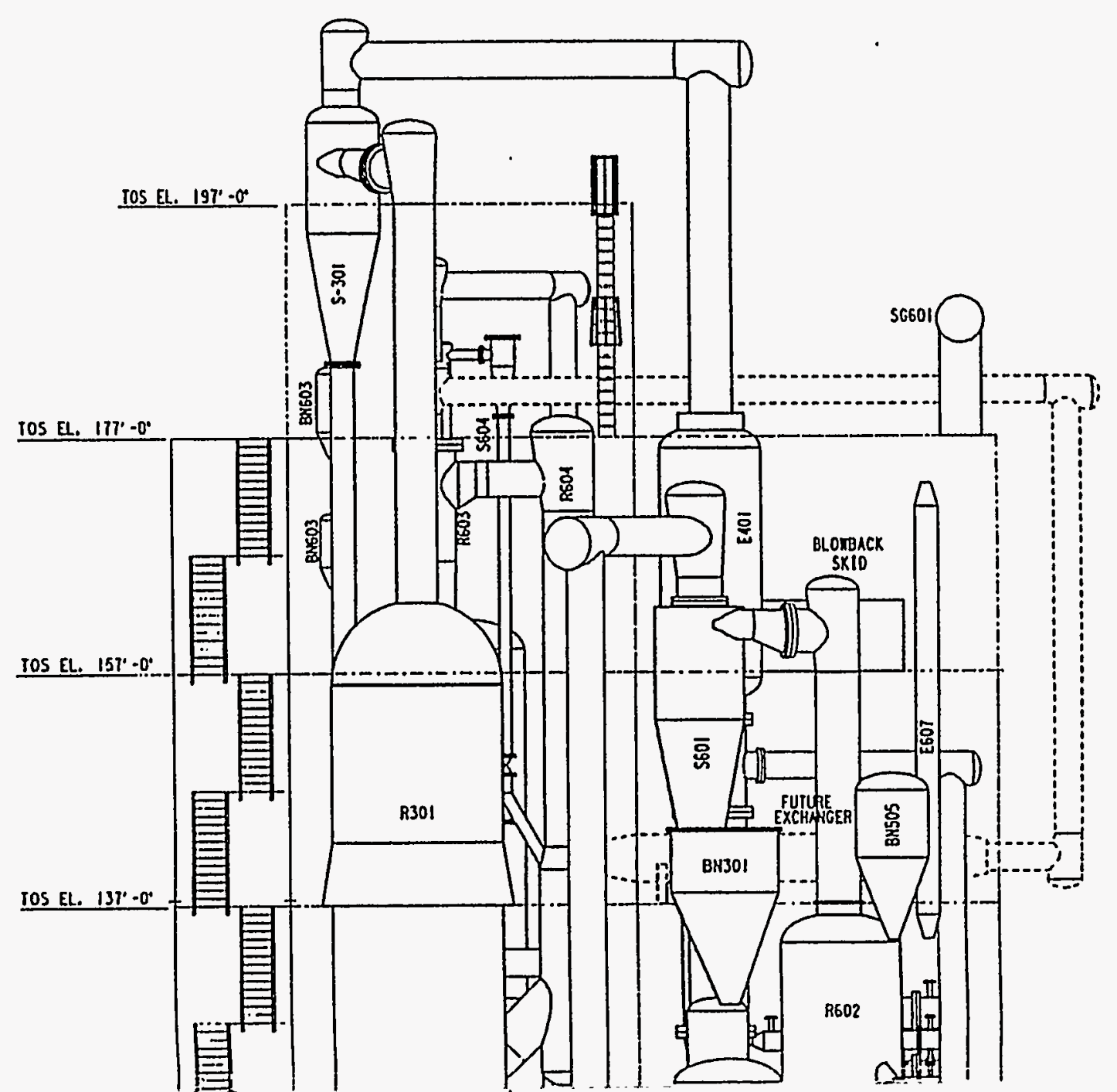




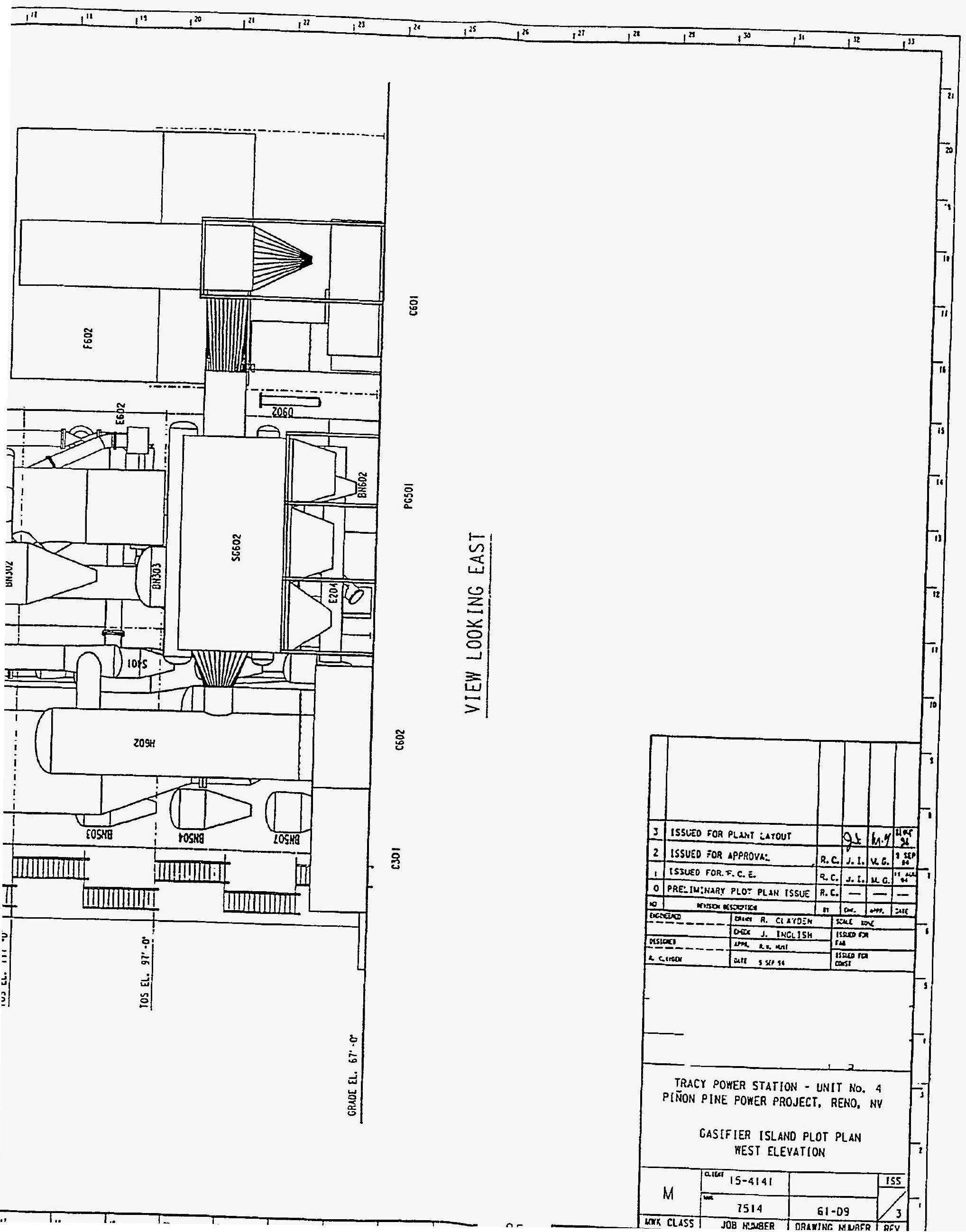



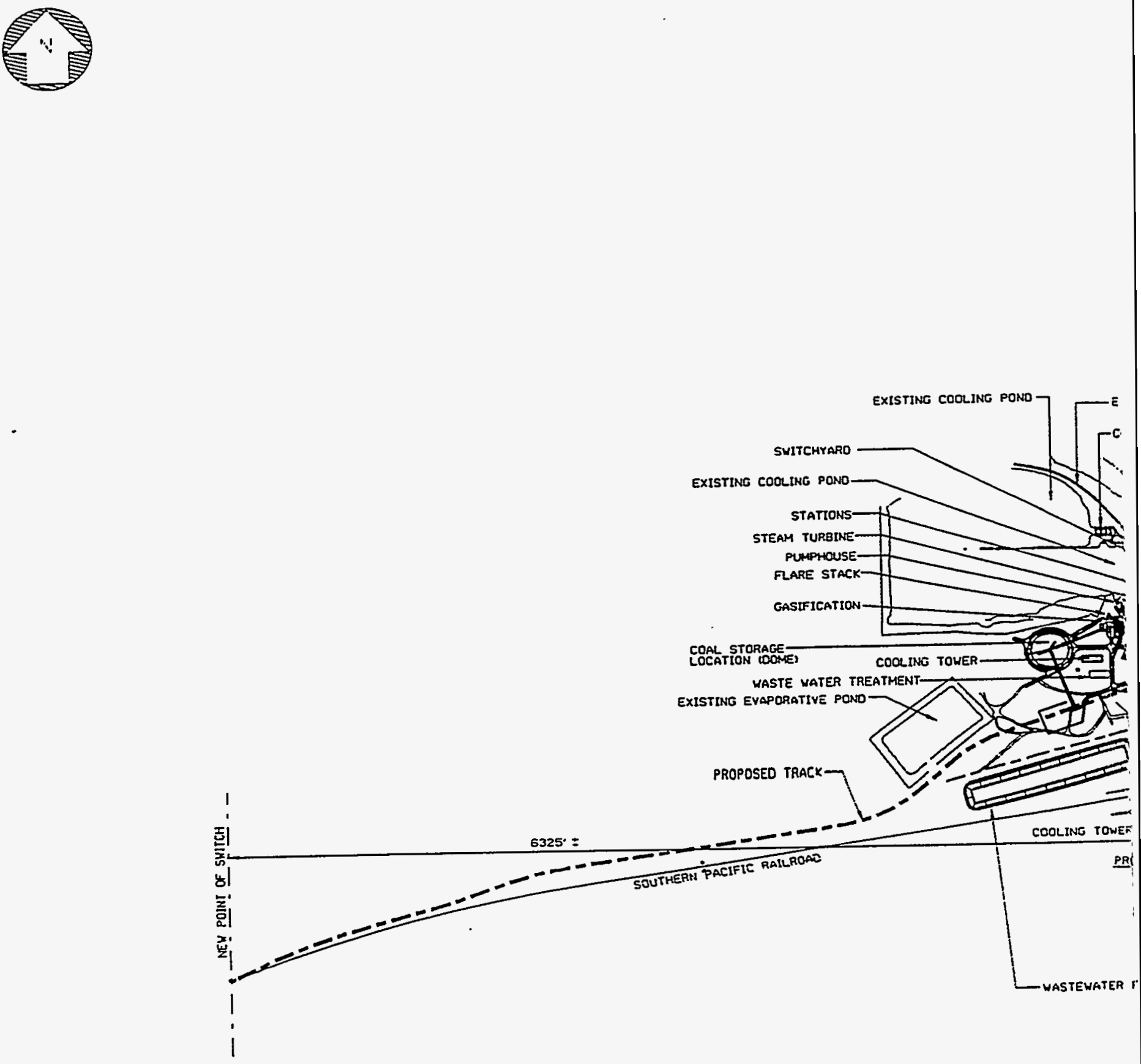


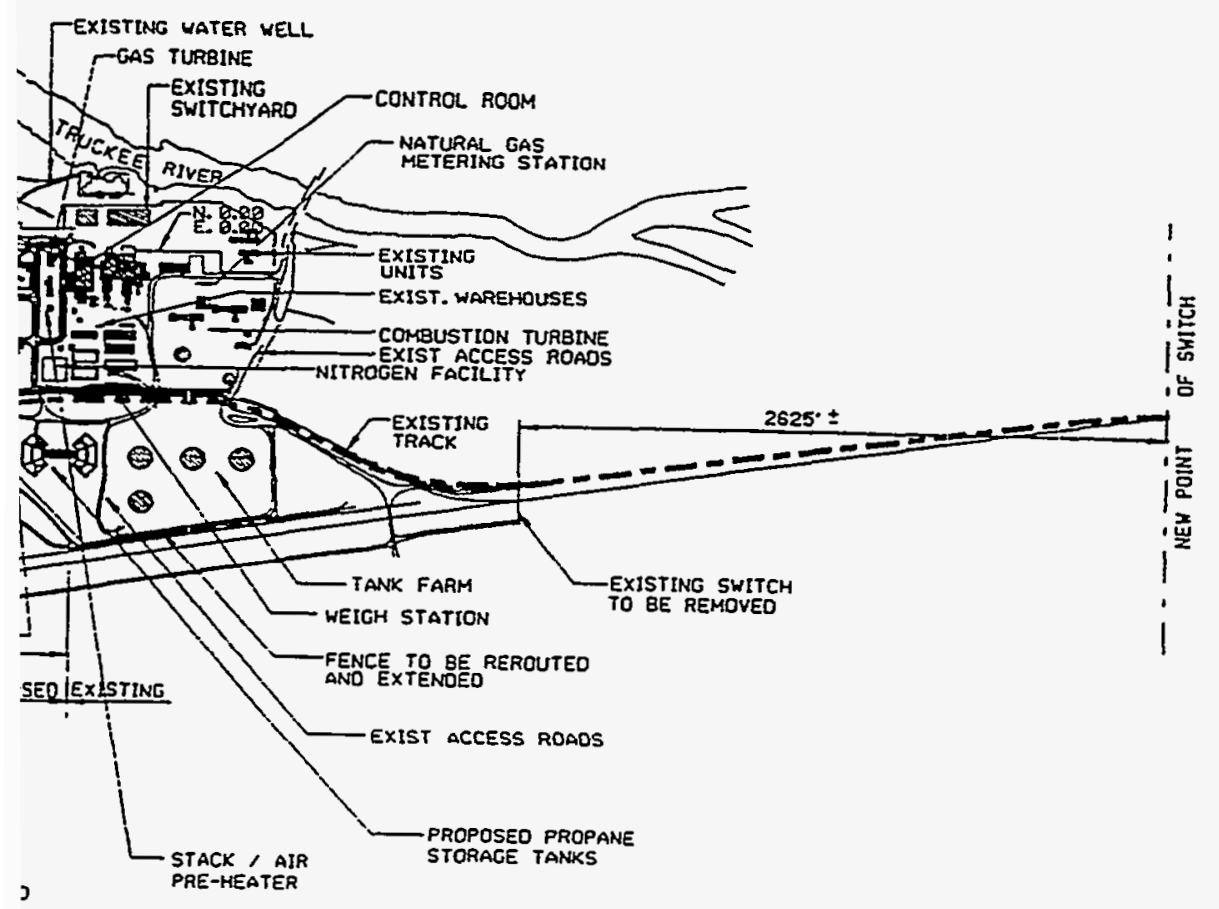




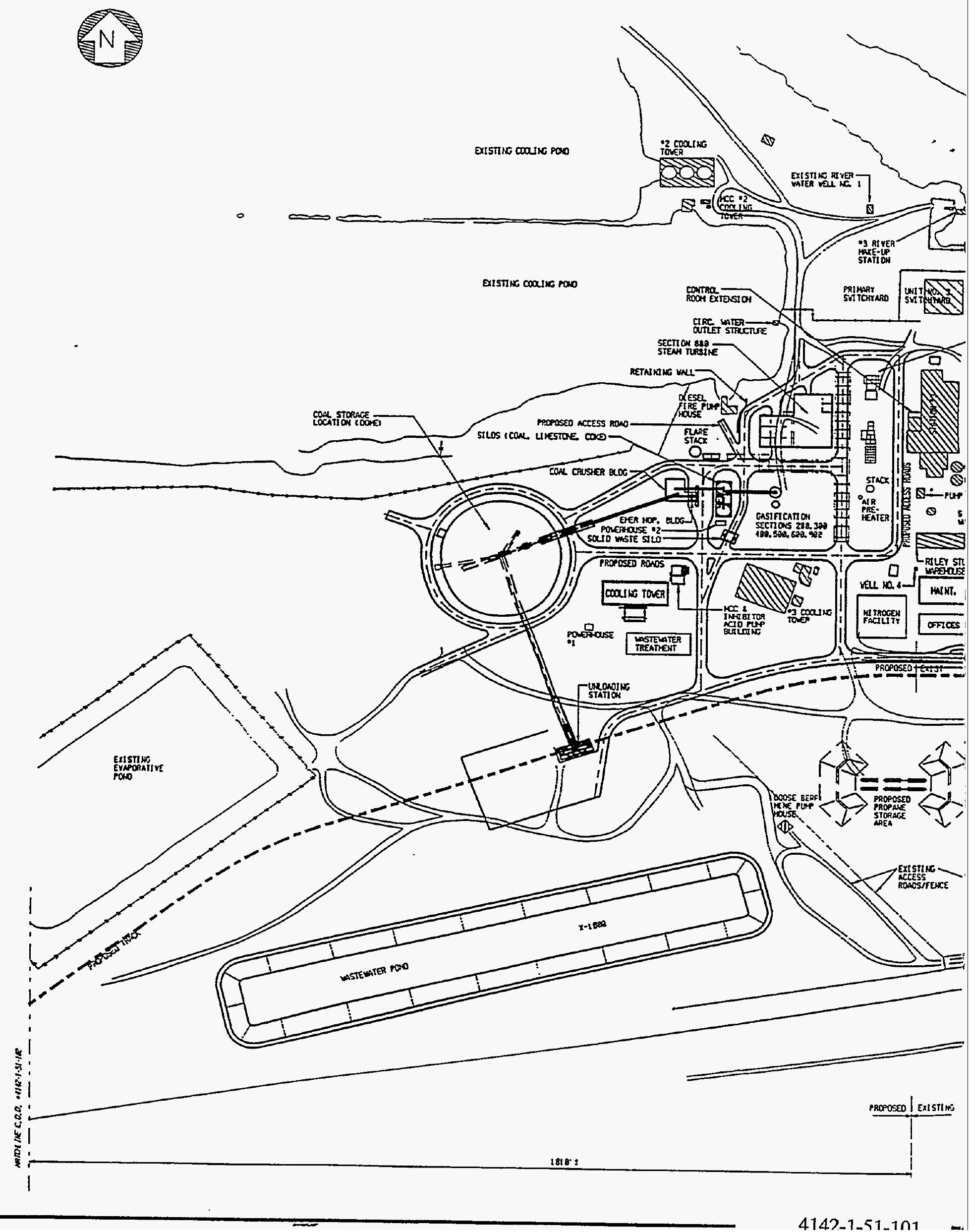




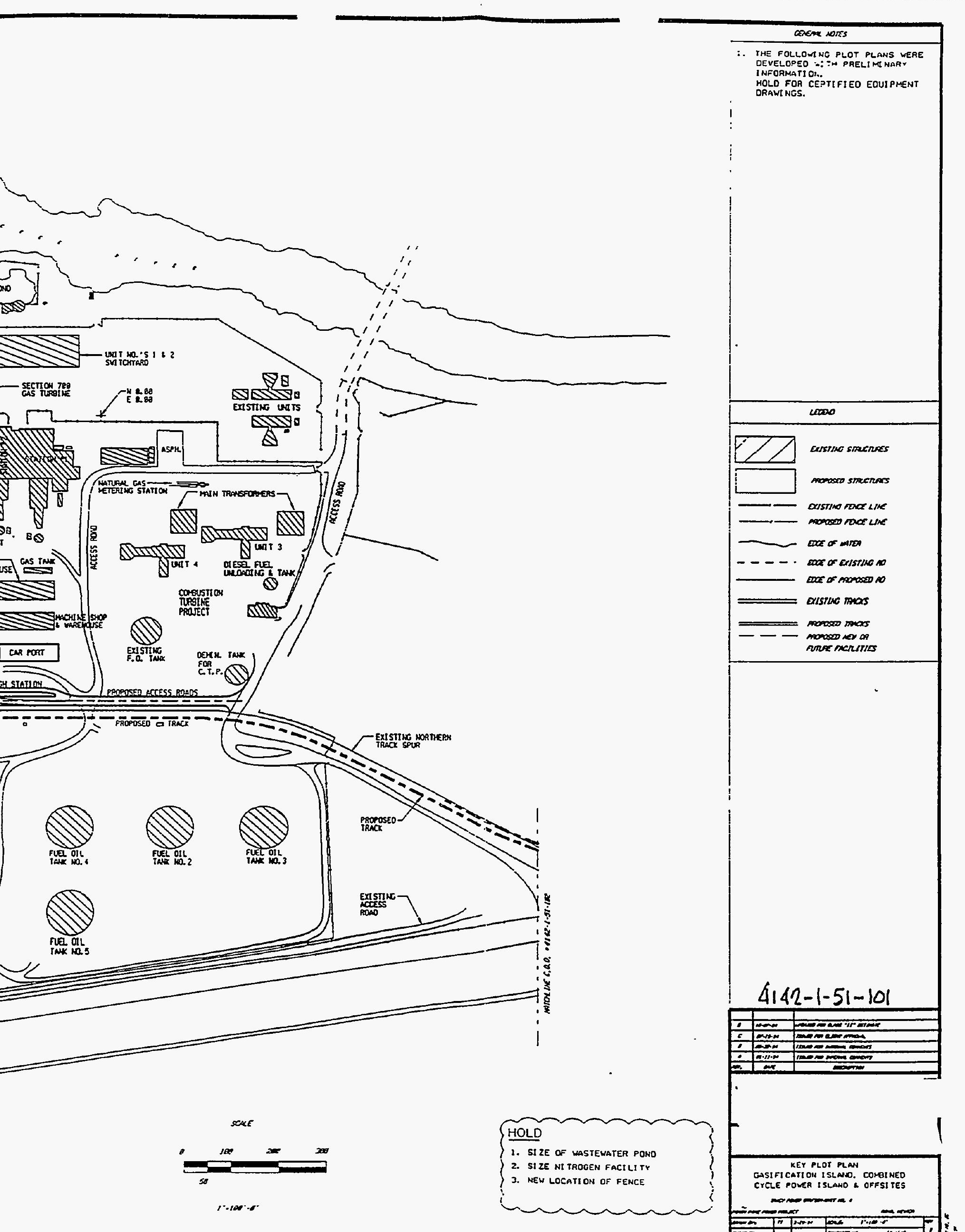




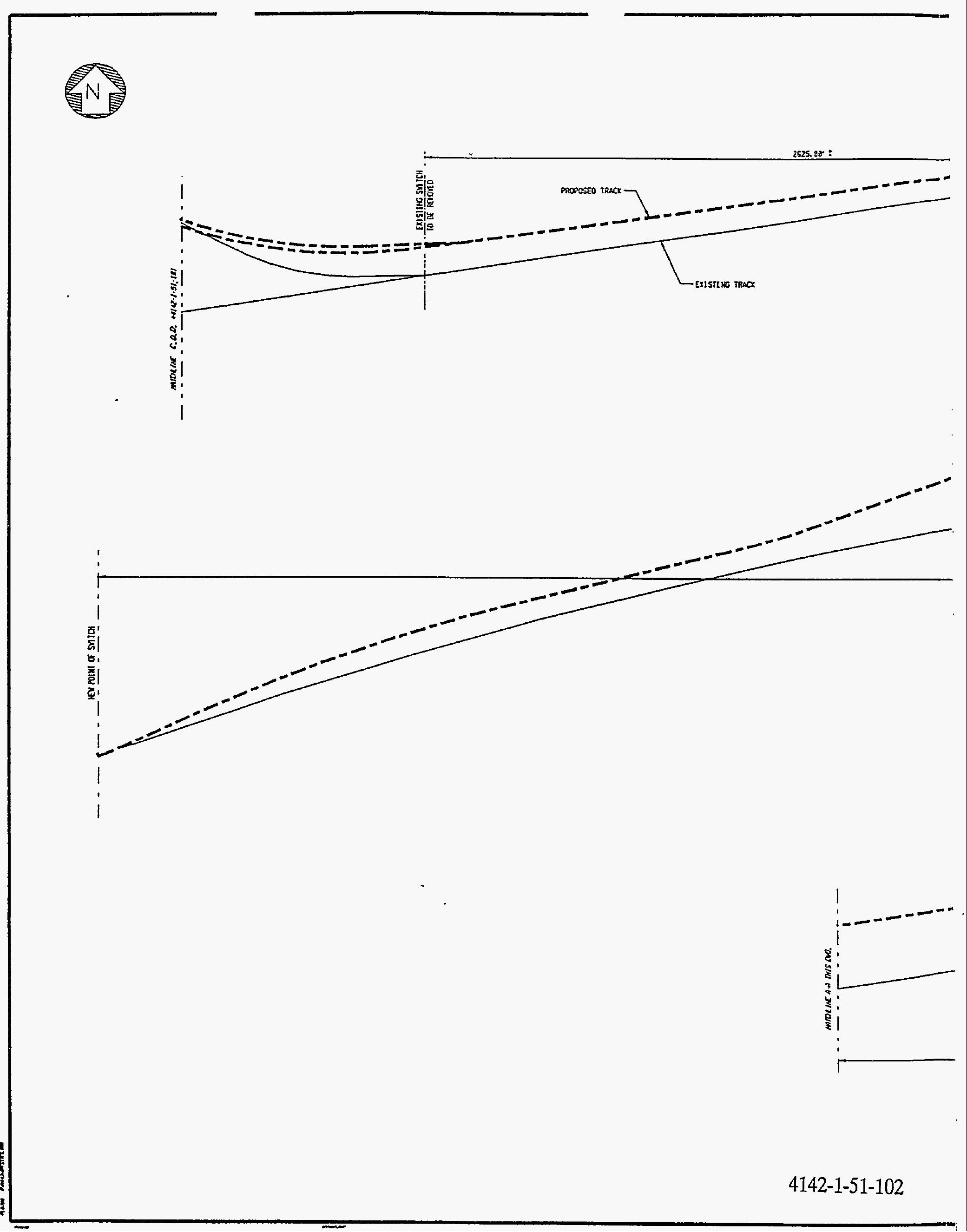



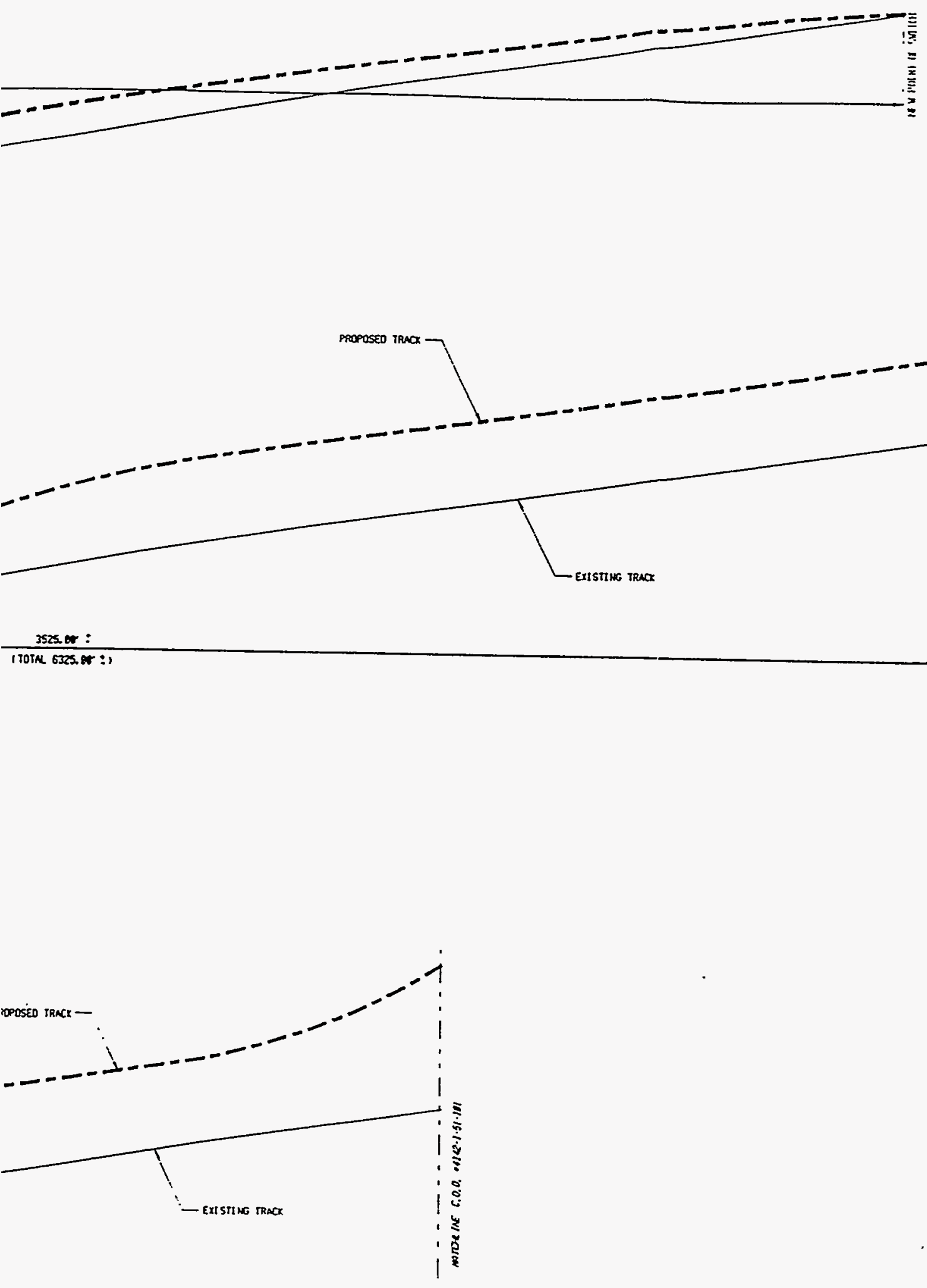

998.88 :

$181200:$

(5EE ONC + 11 \$2 -51-101)
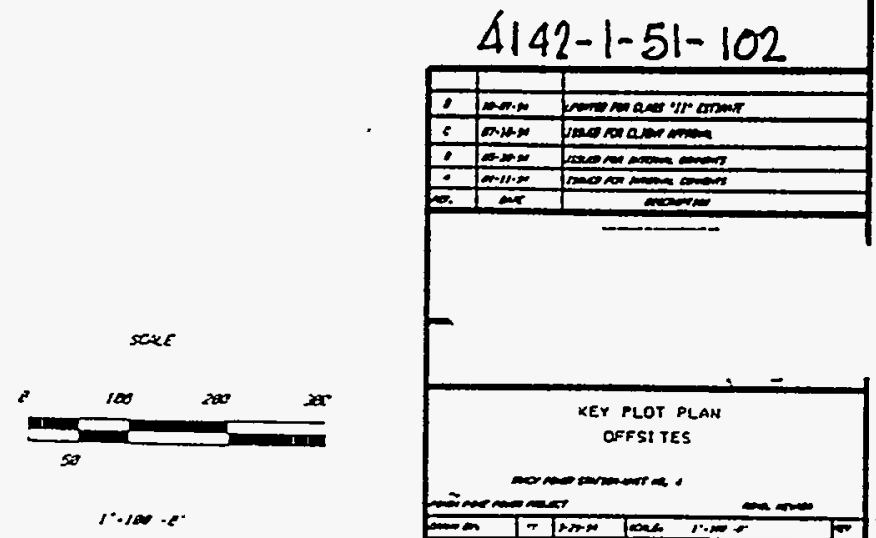


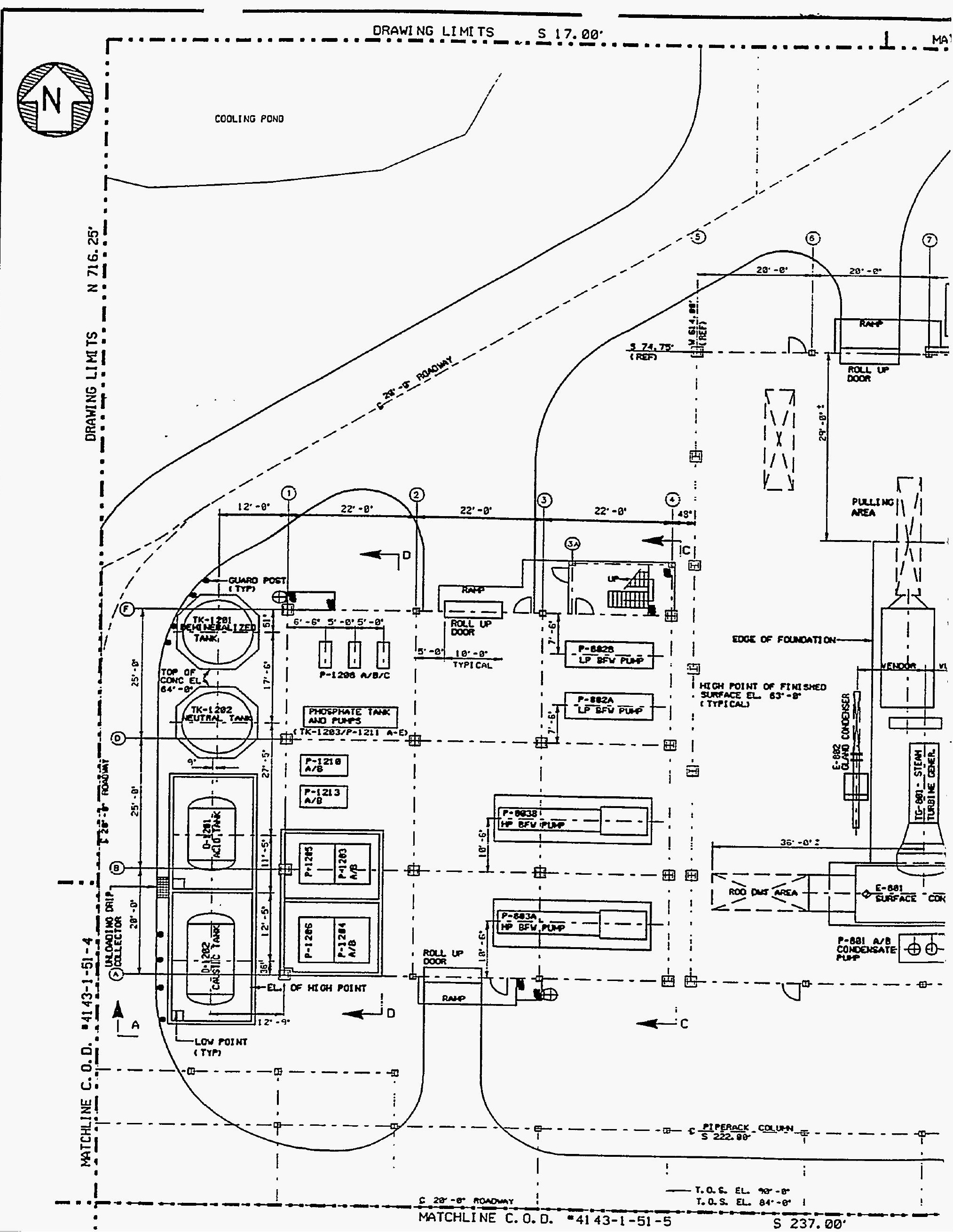




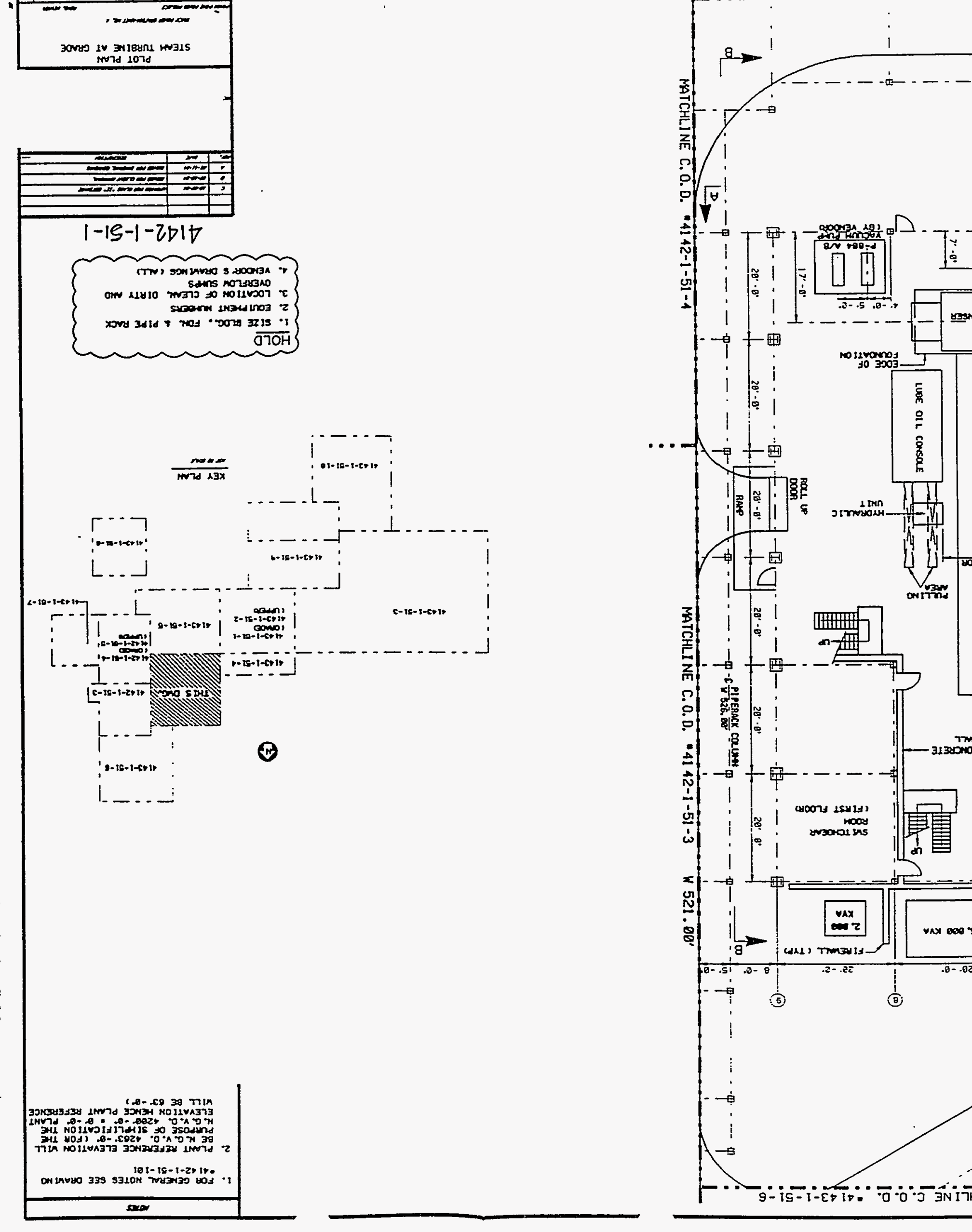




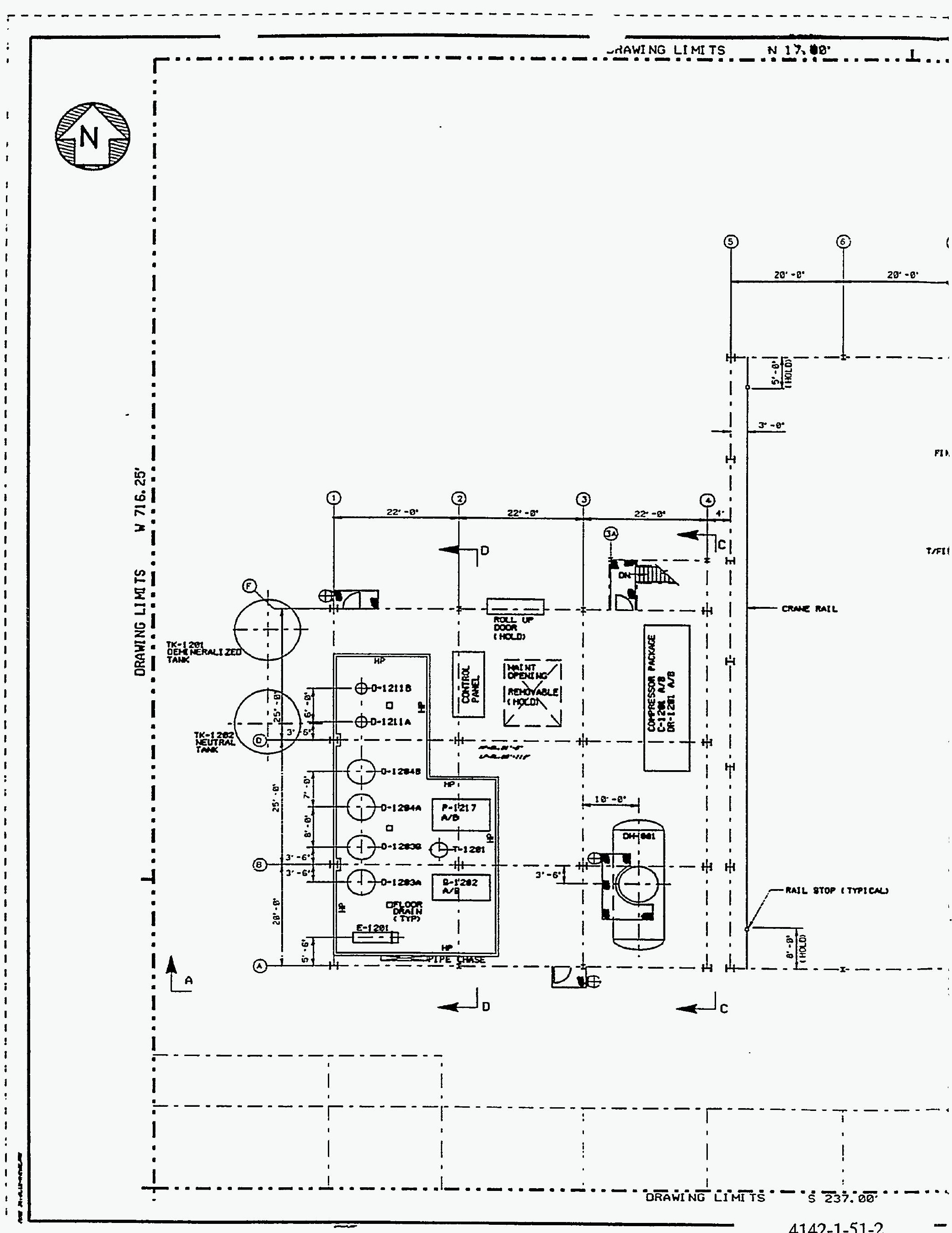




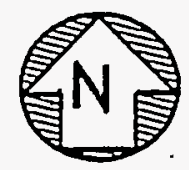

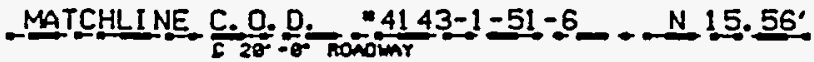

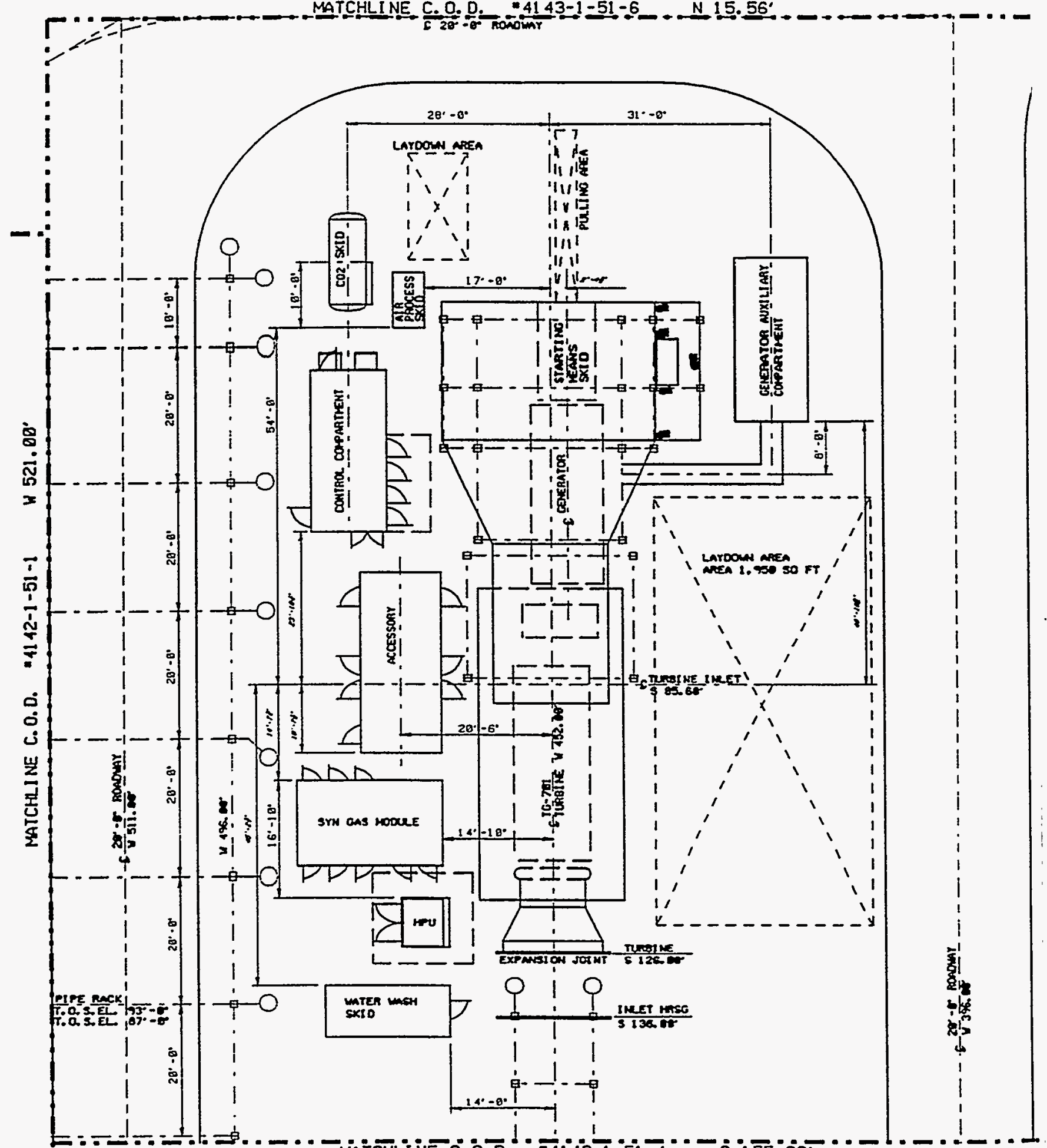
i

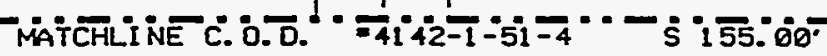



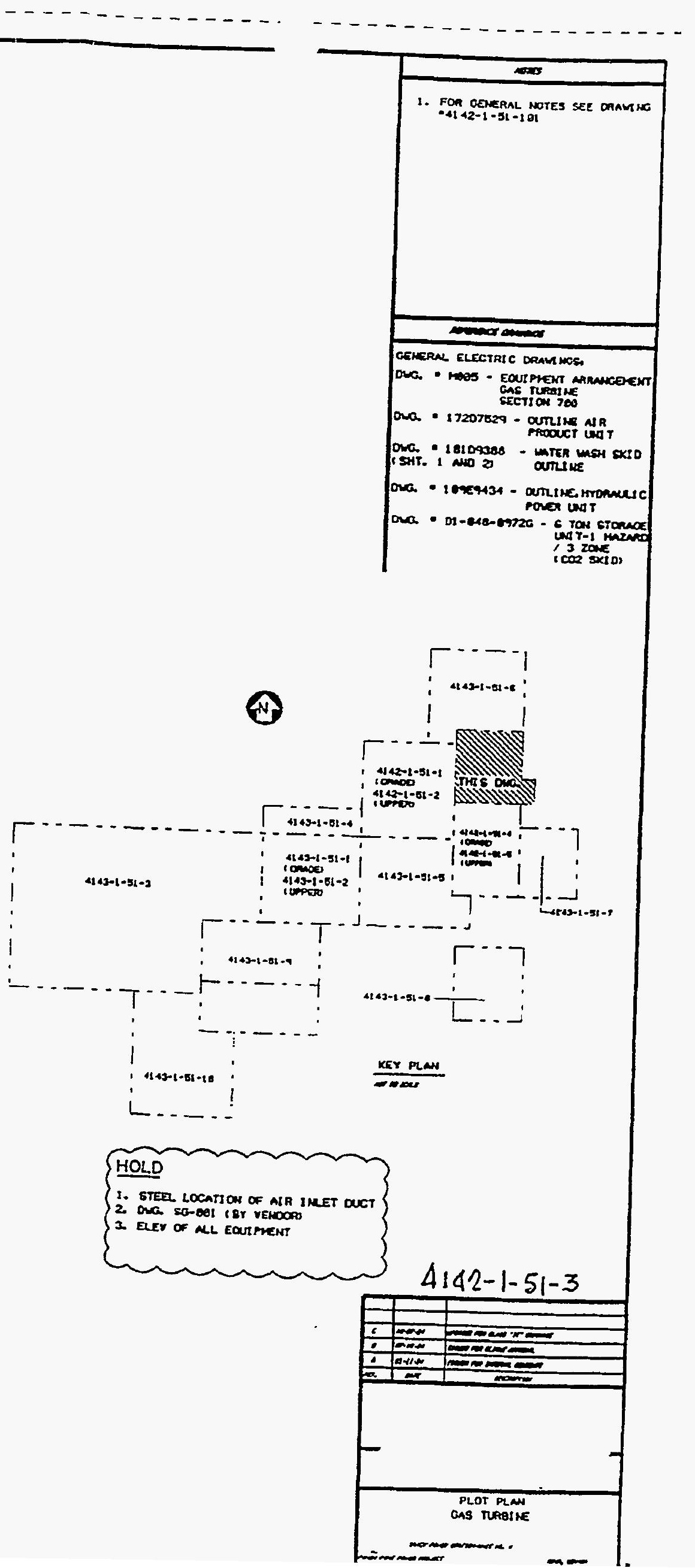

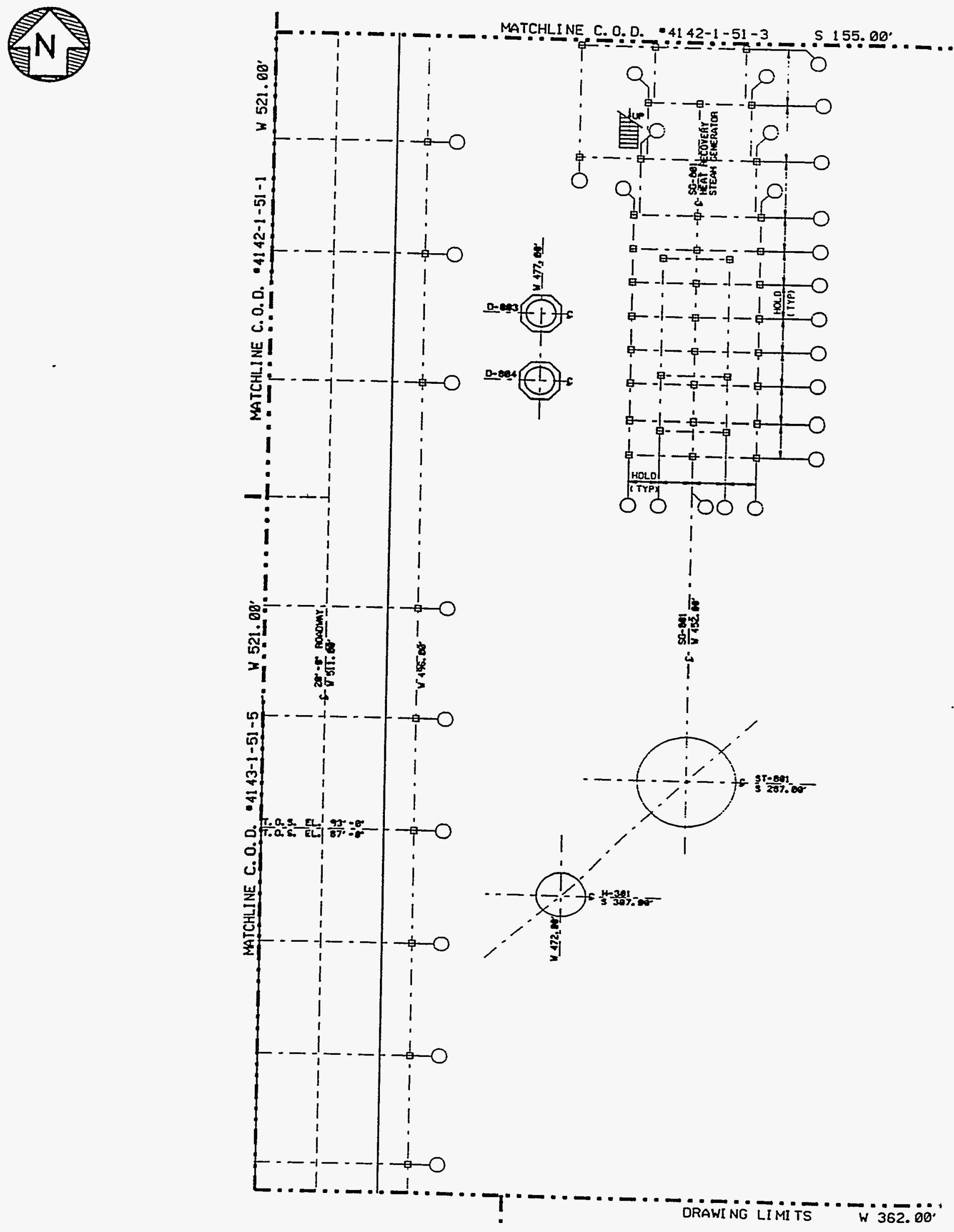

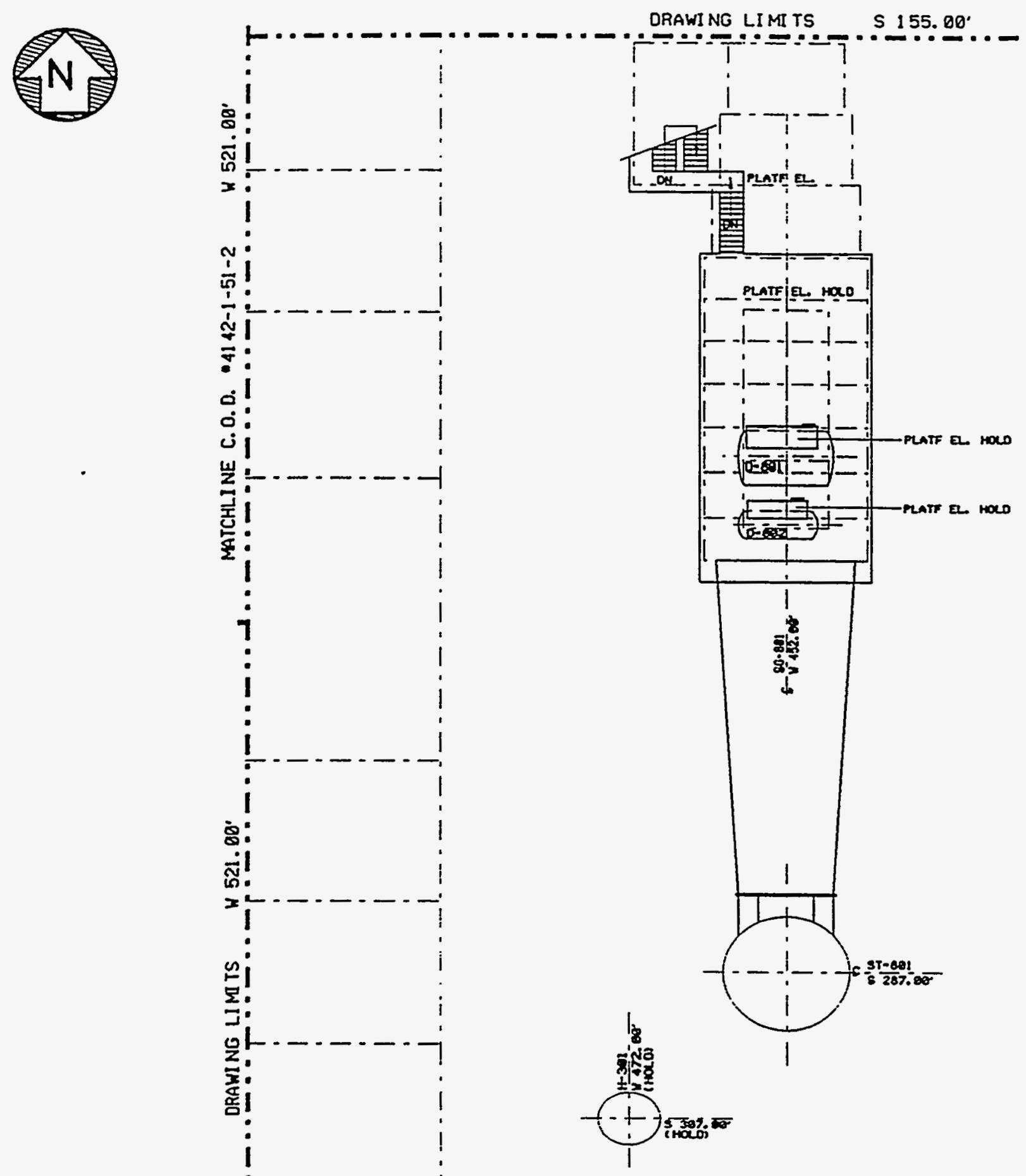

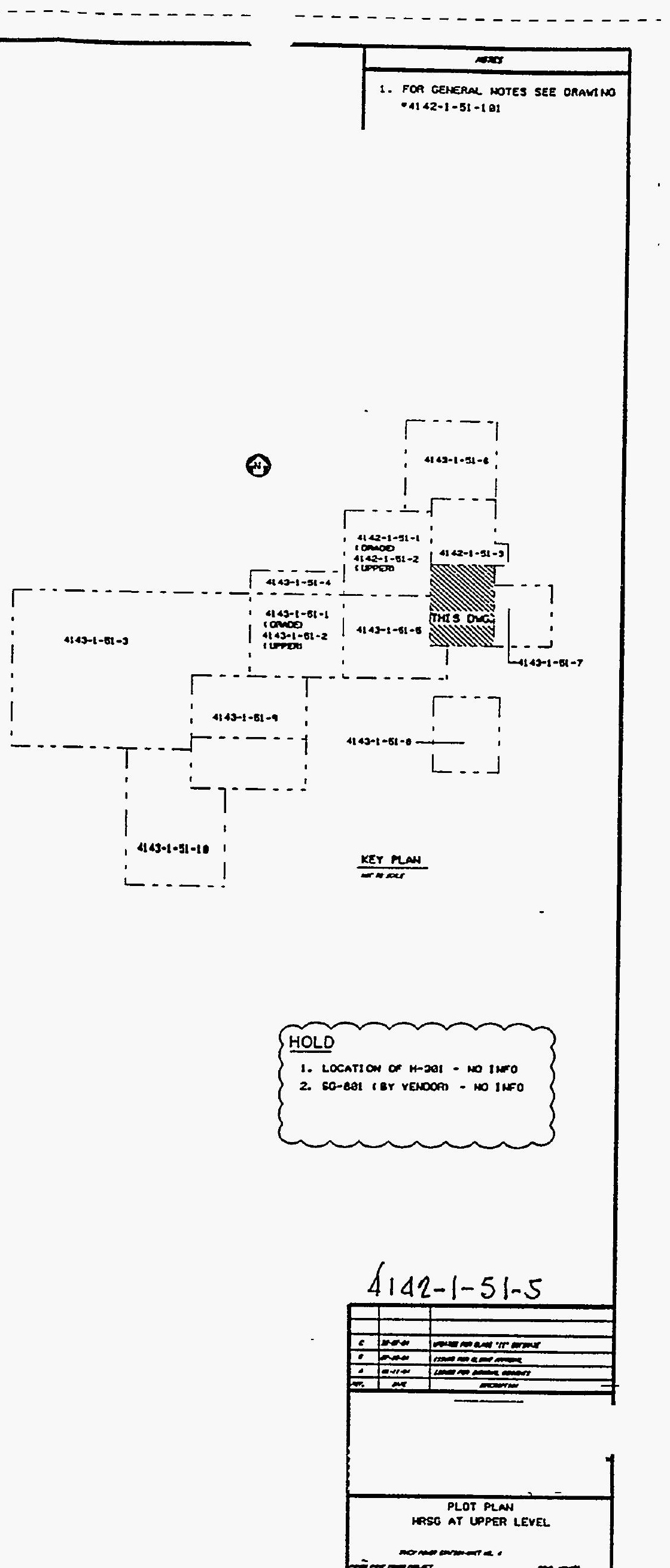

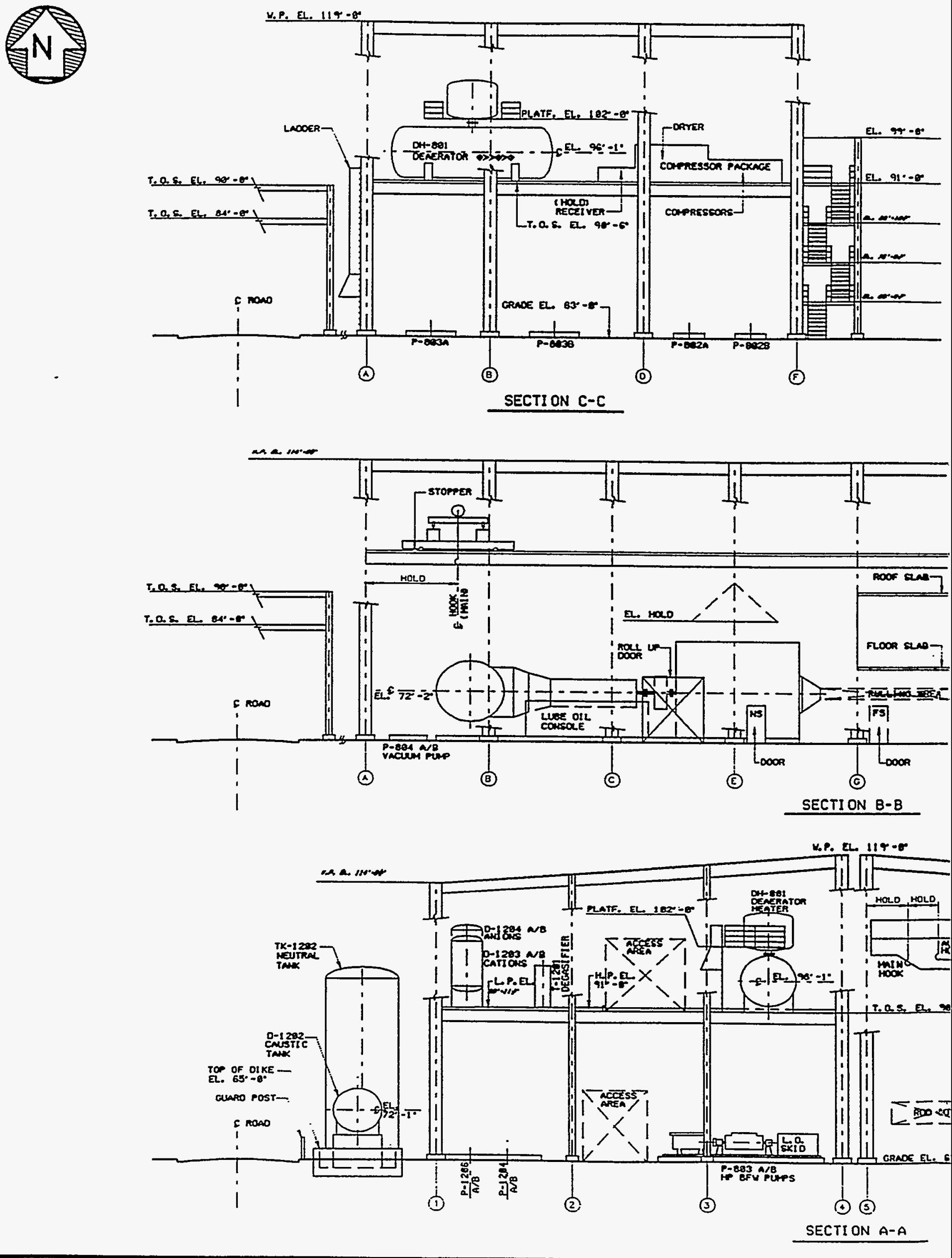

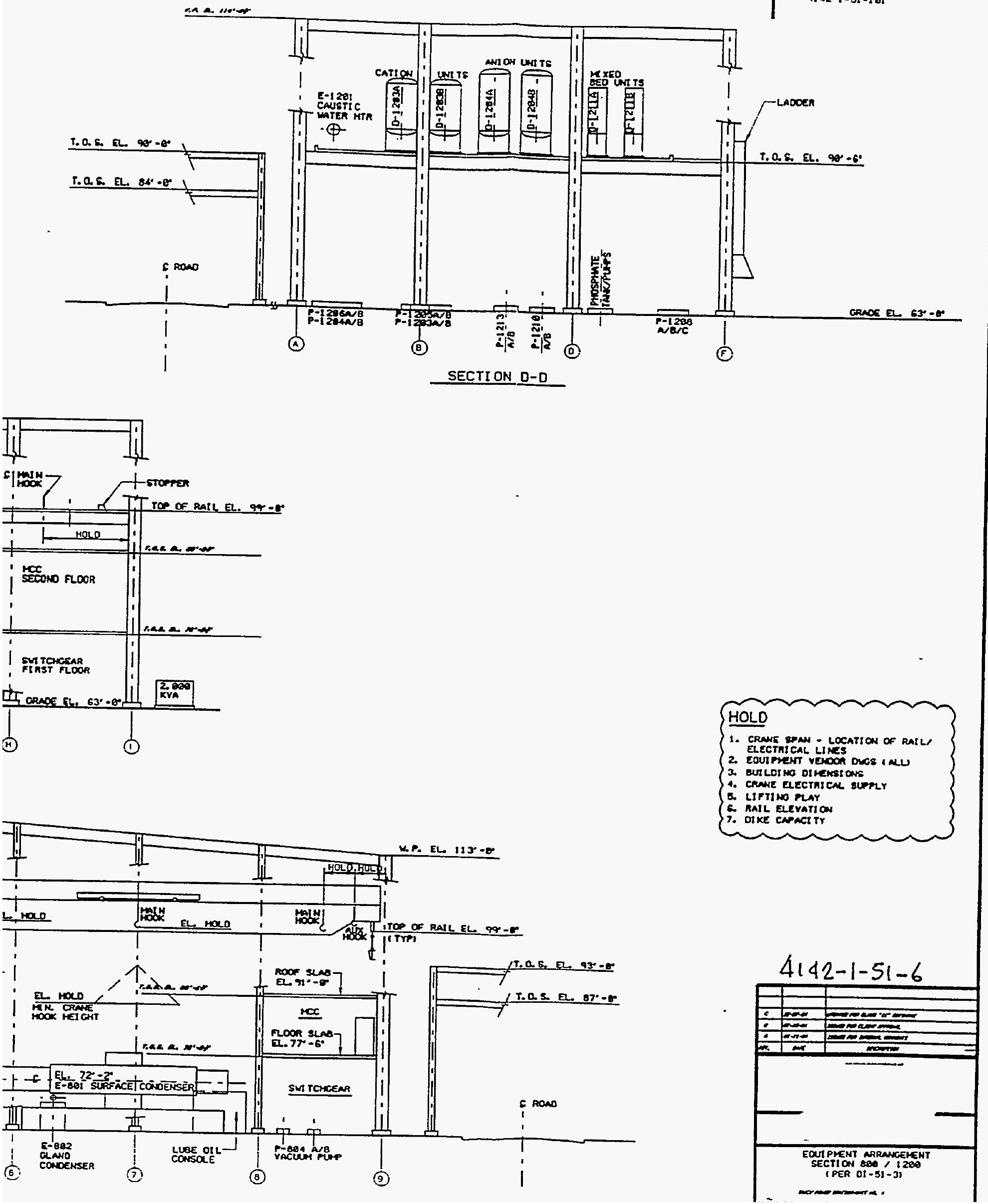


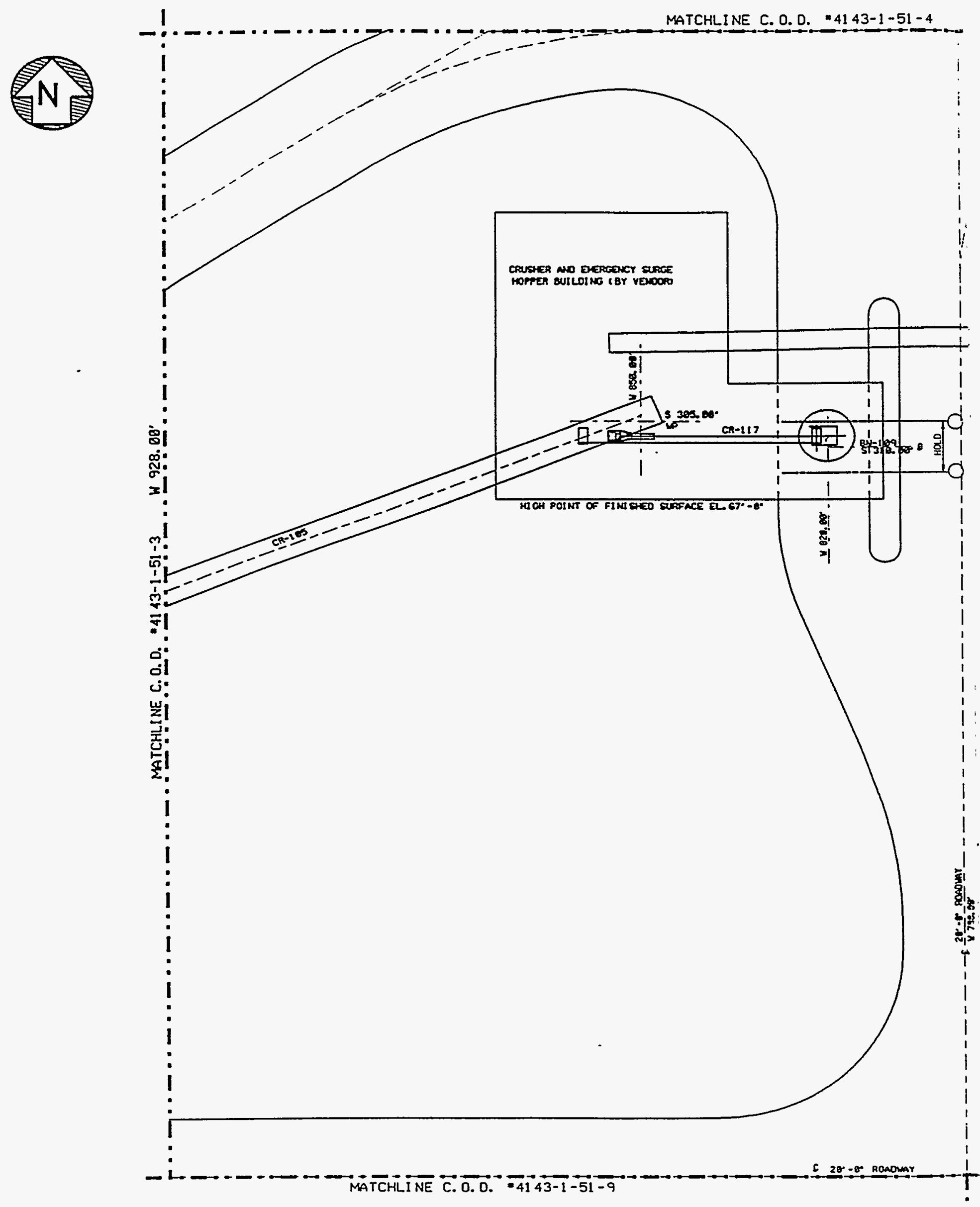

4143-1-51-1 


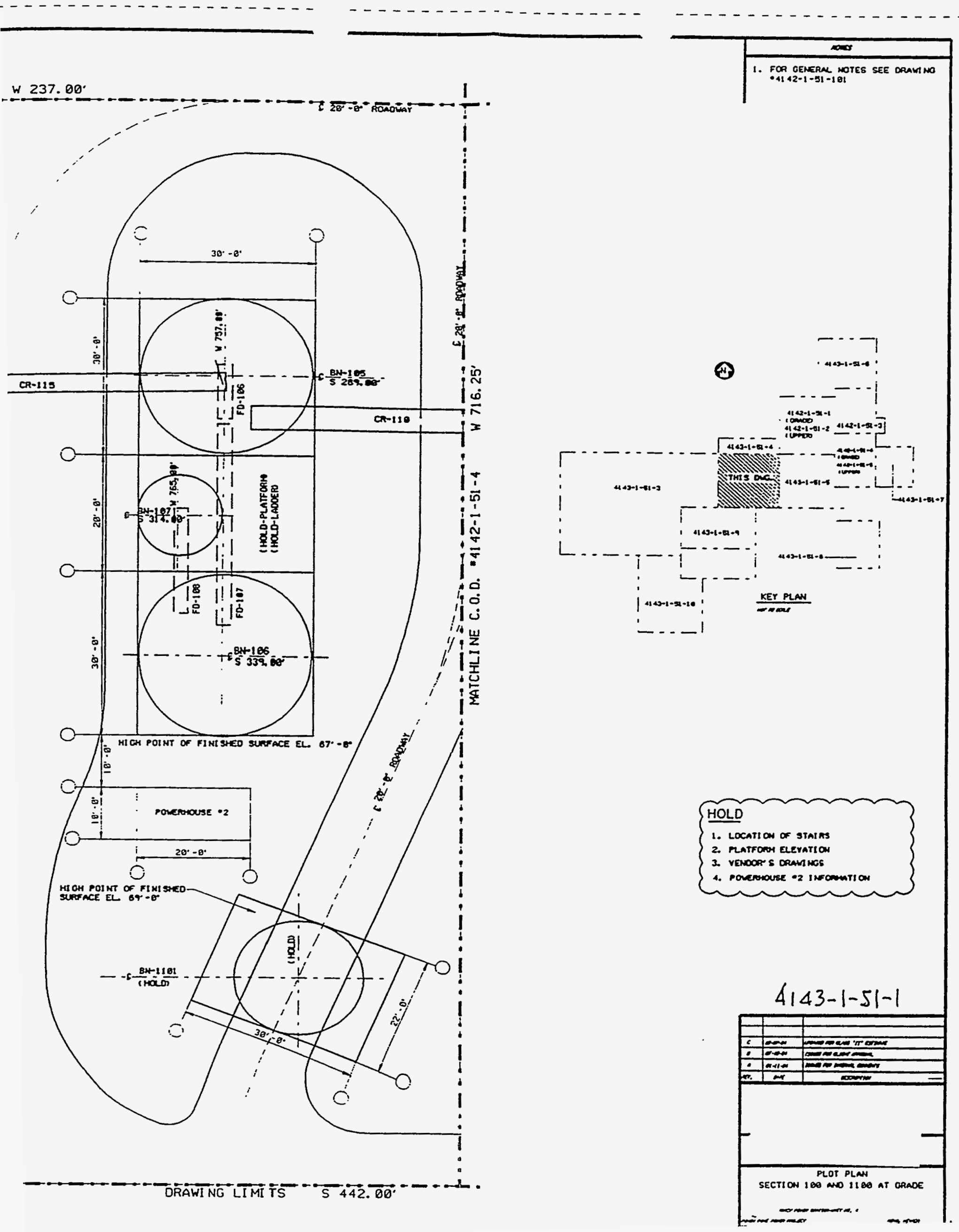




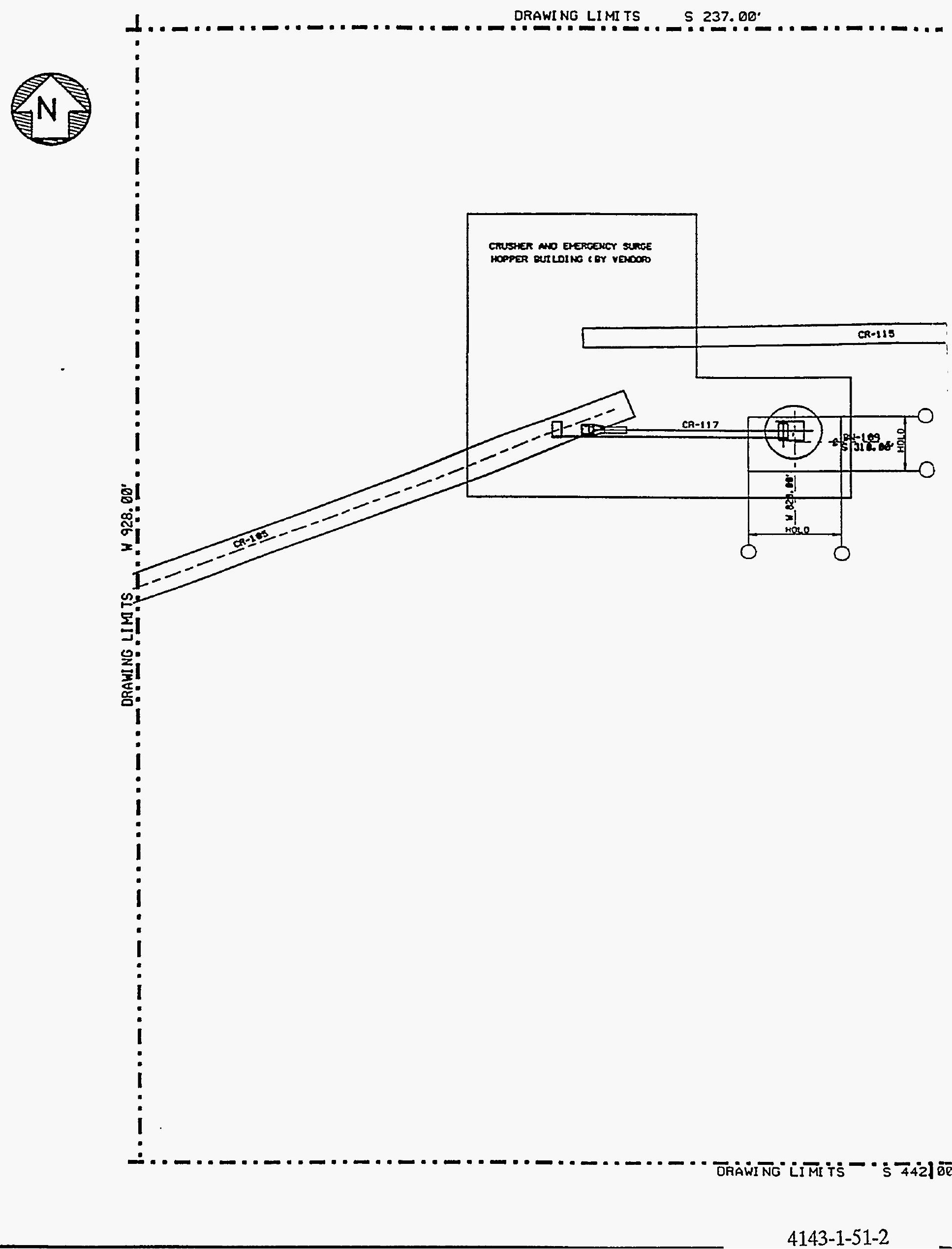



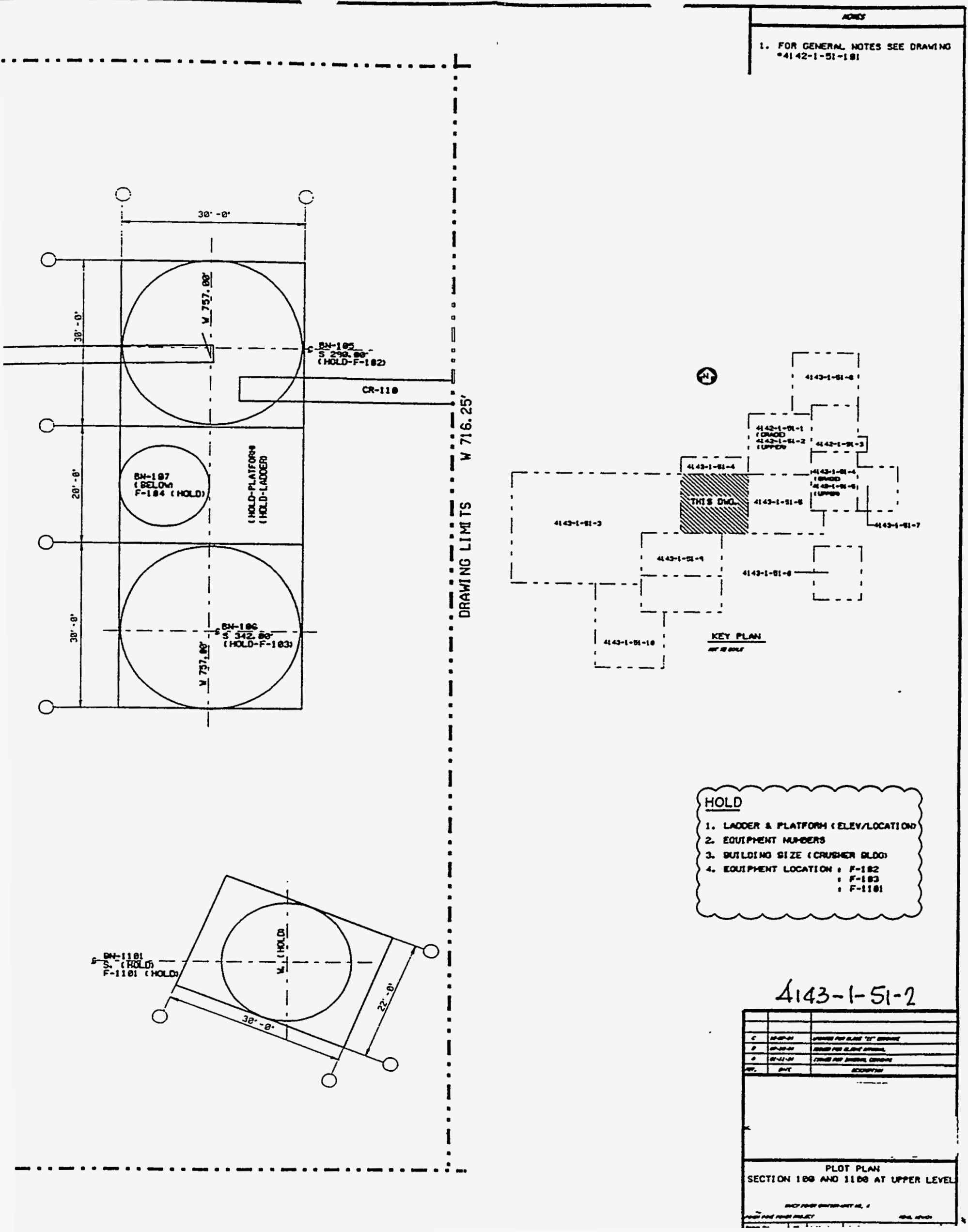



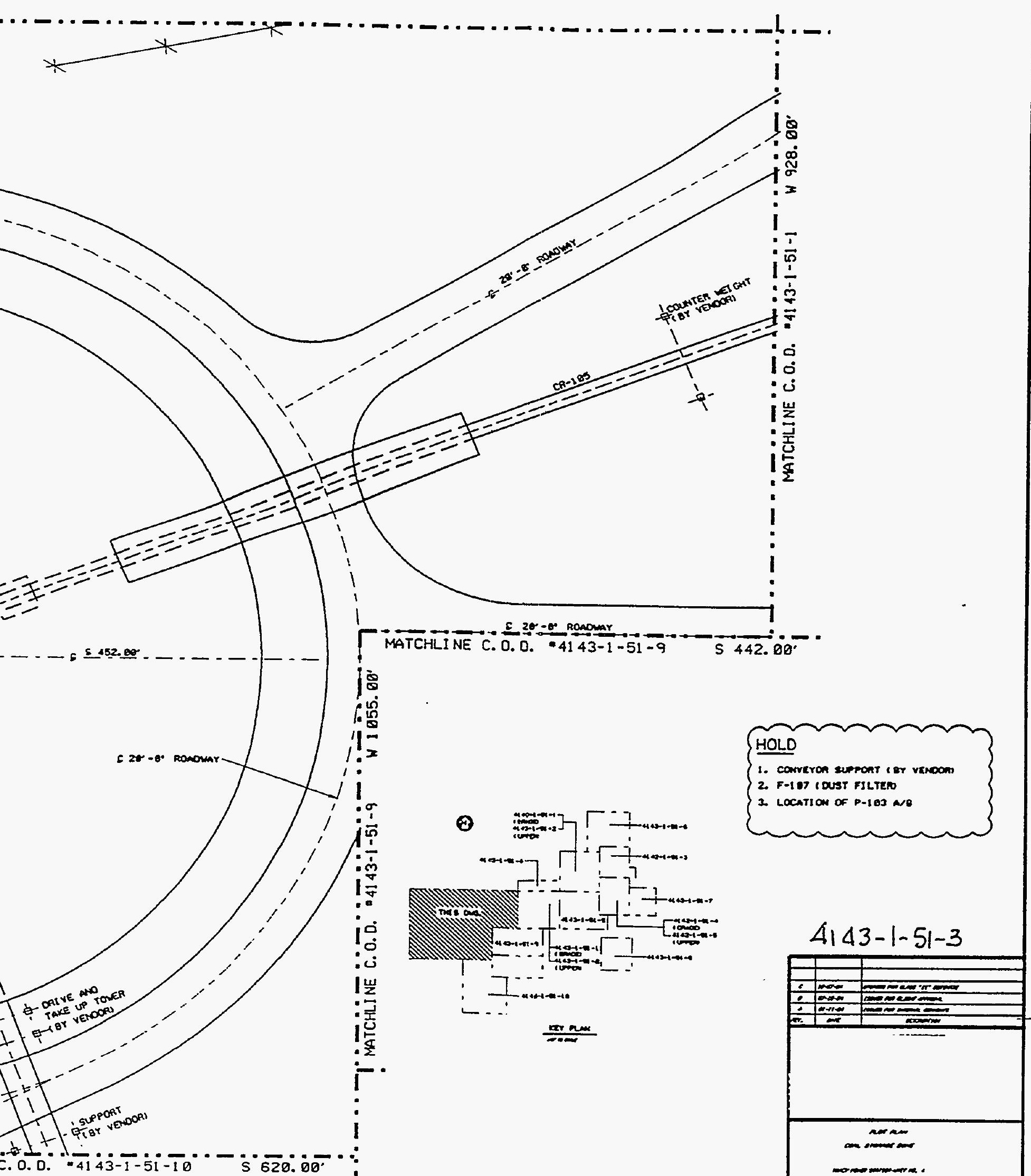




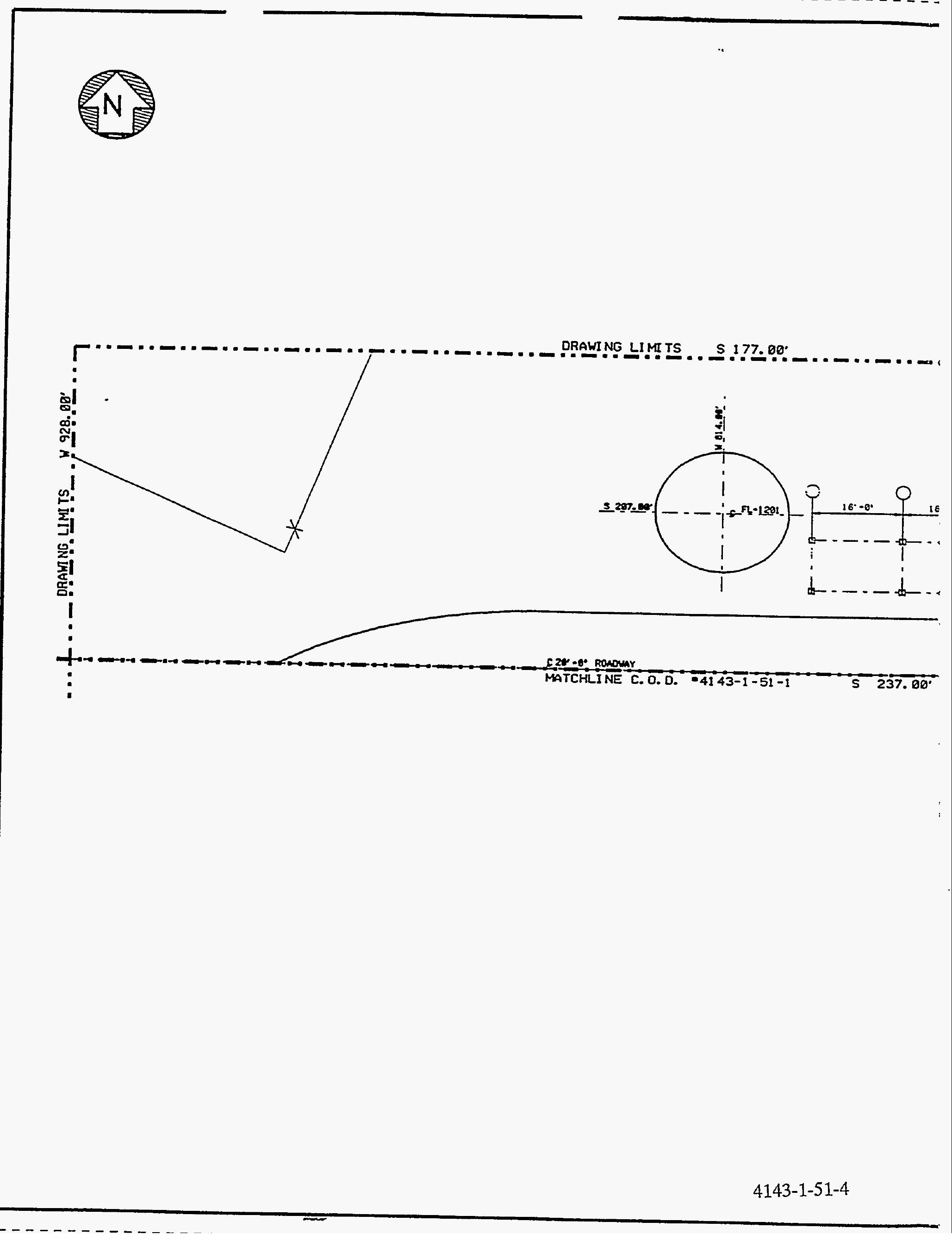



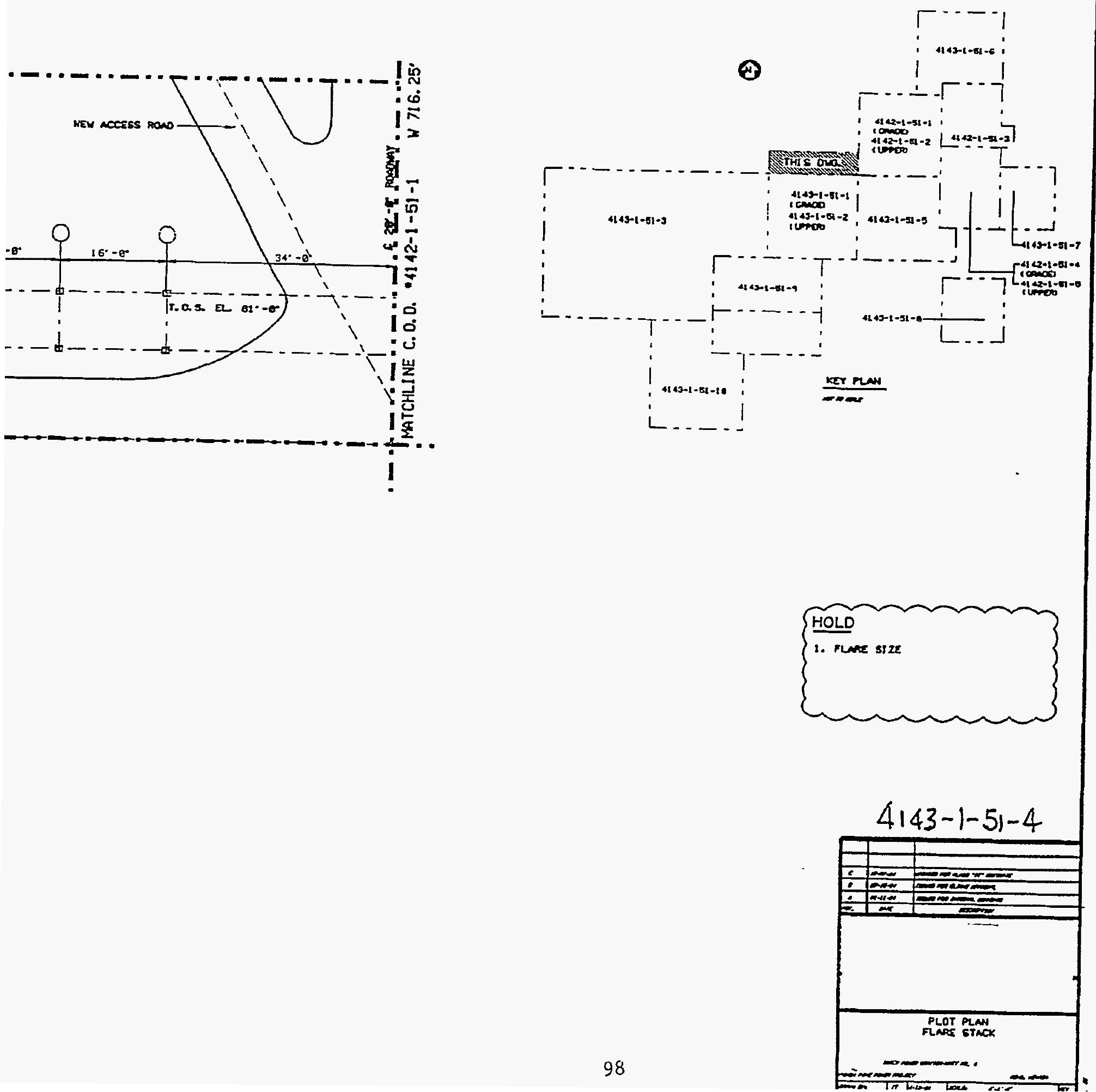


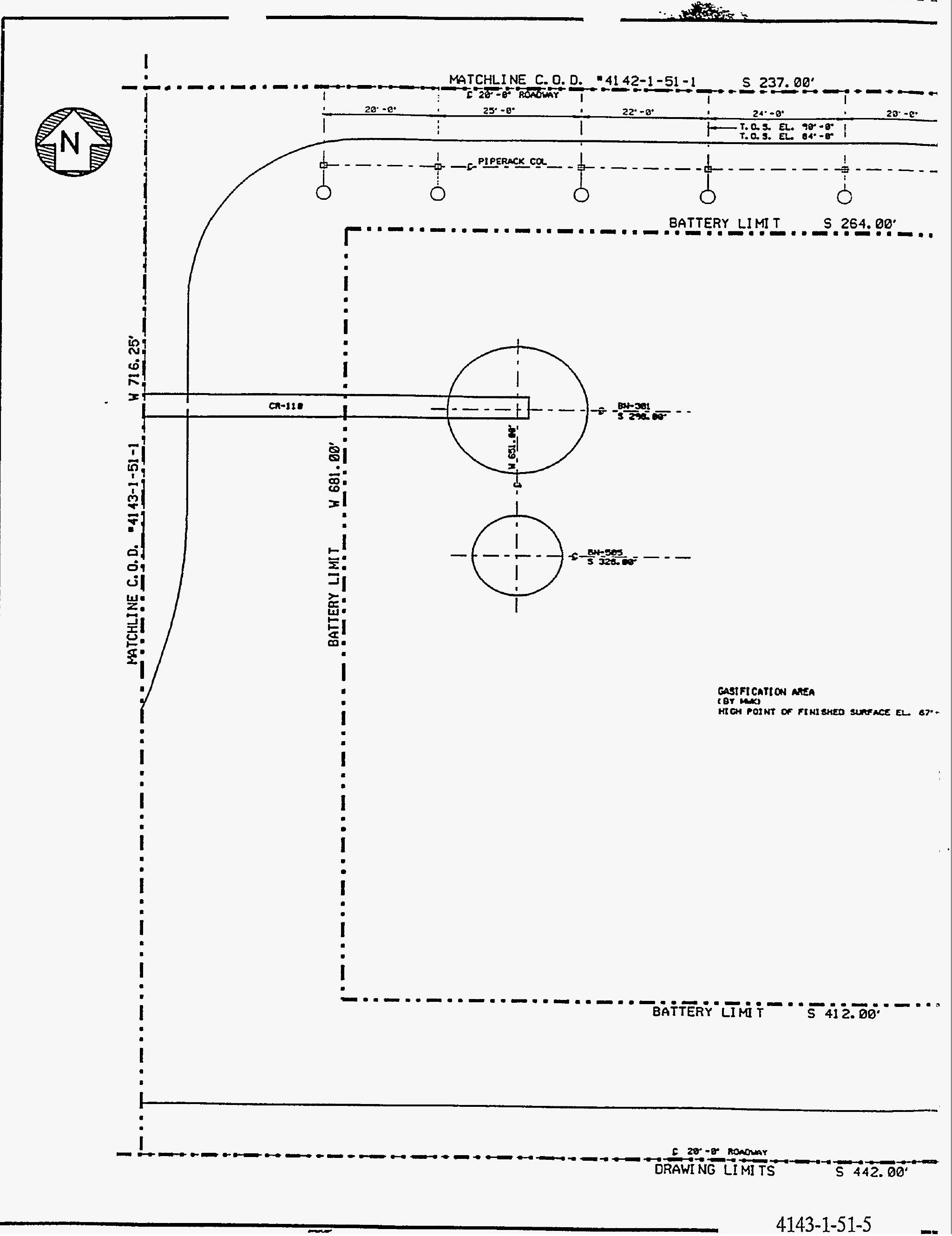




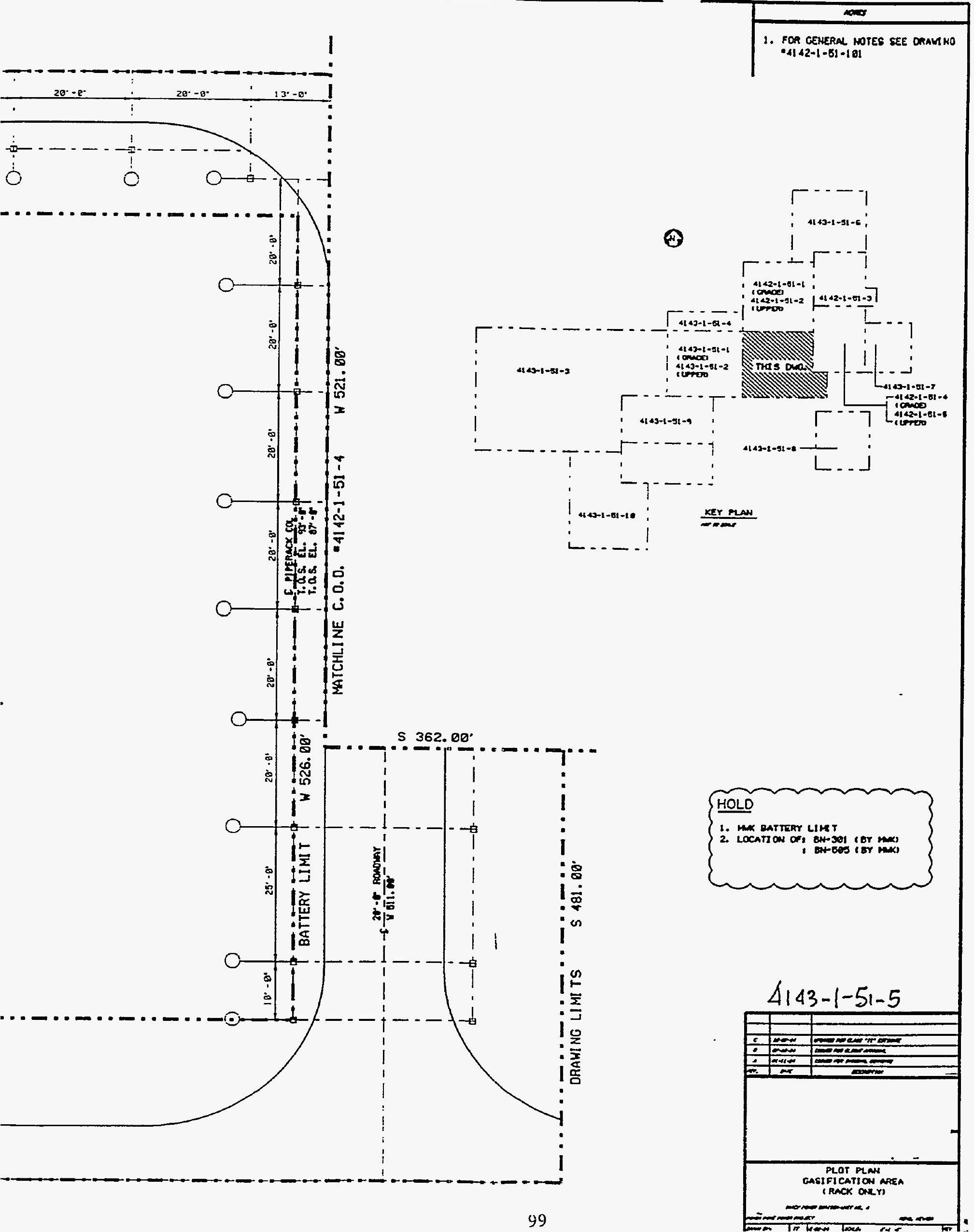




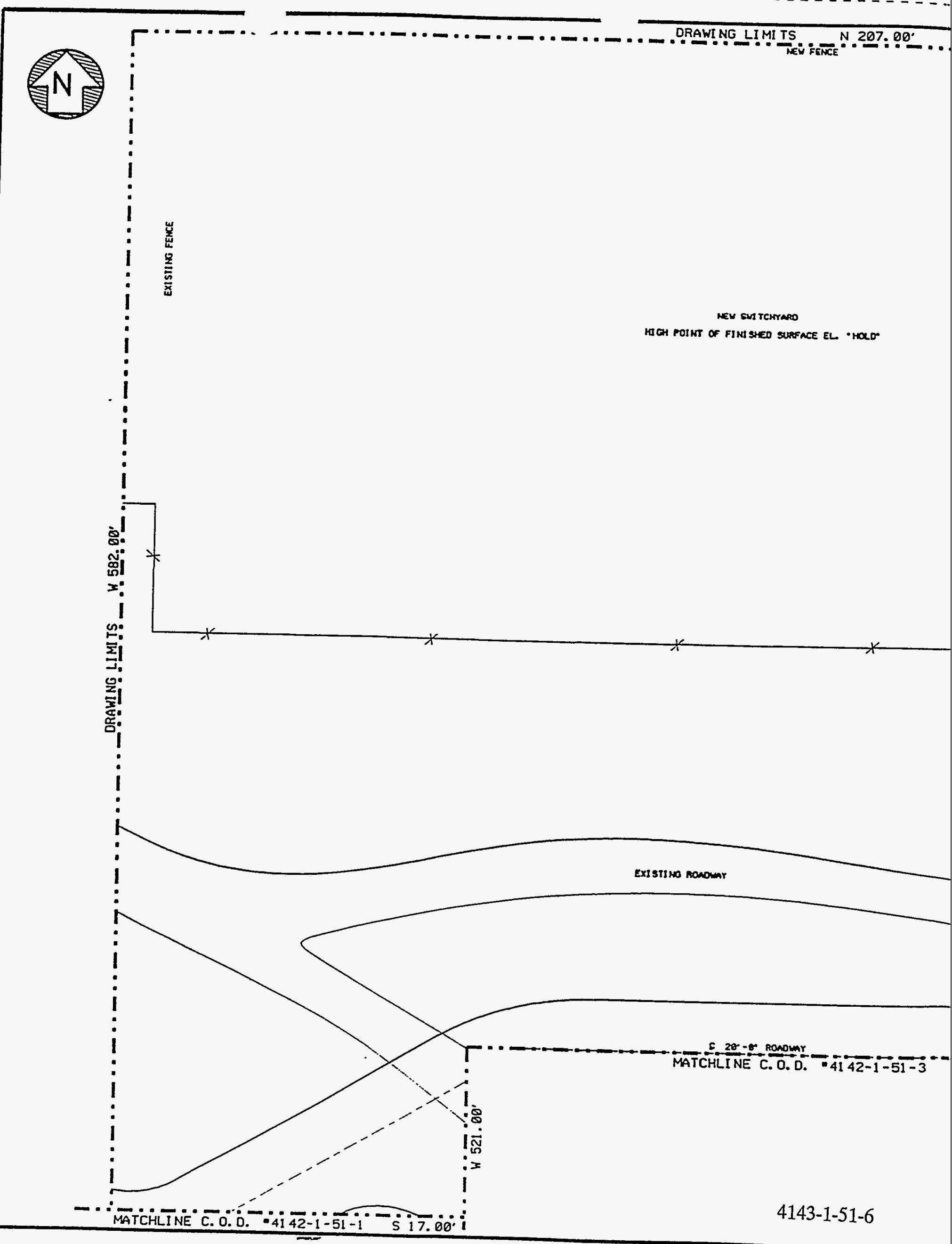


N

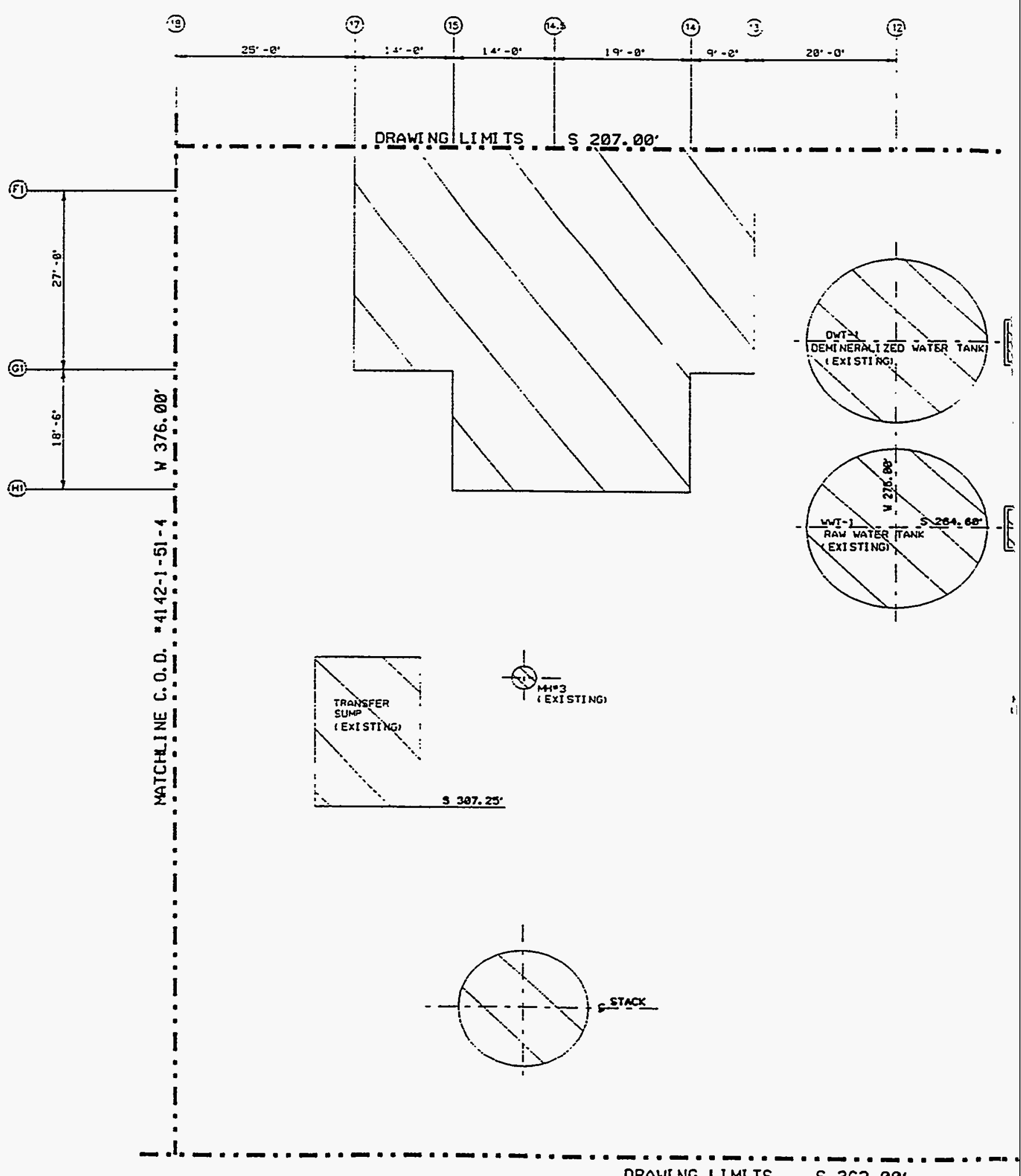

DRAWING LIMITS S $362.00^{\circ}$ 


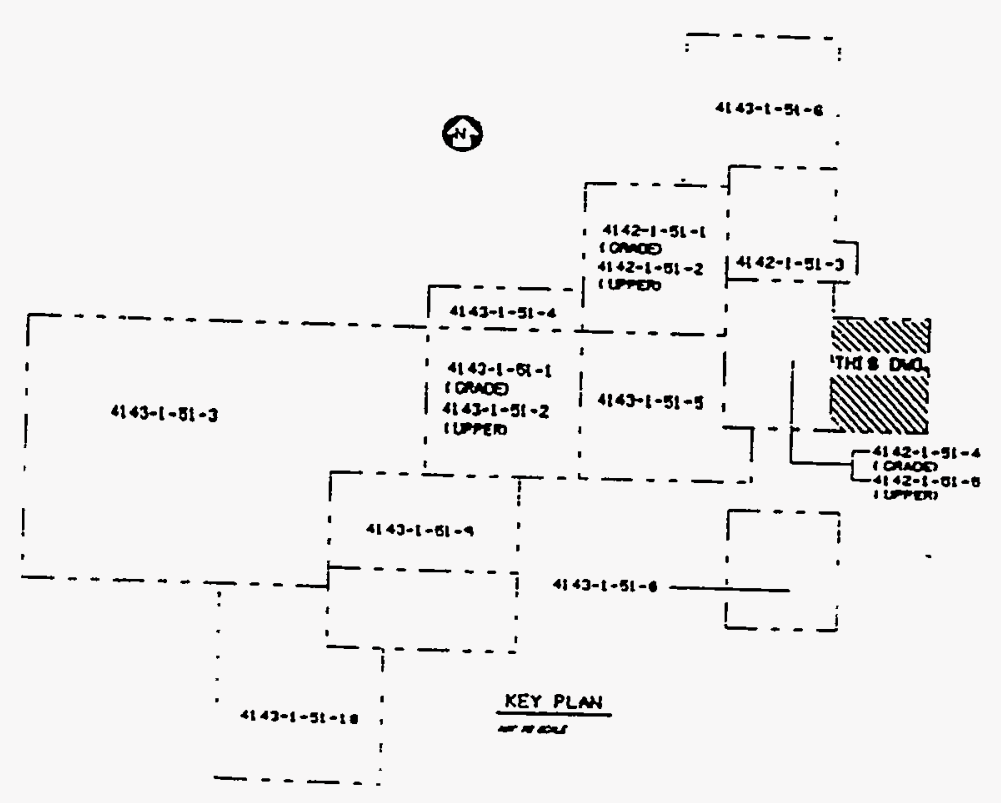



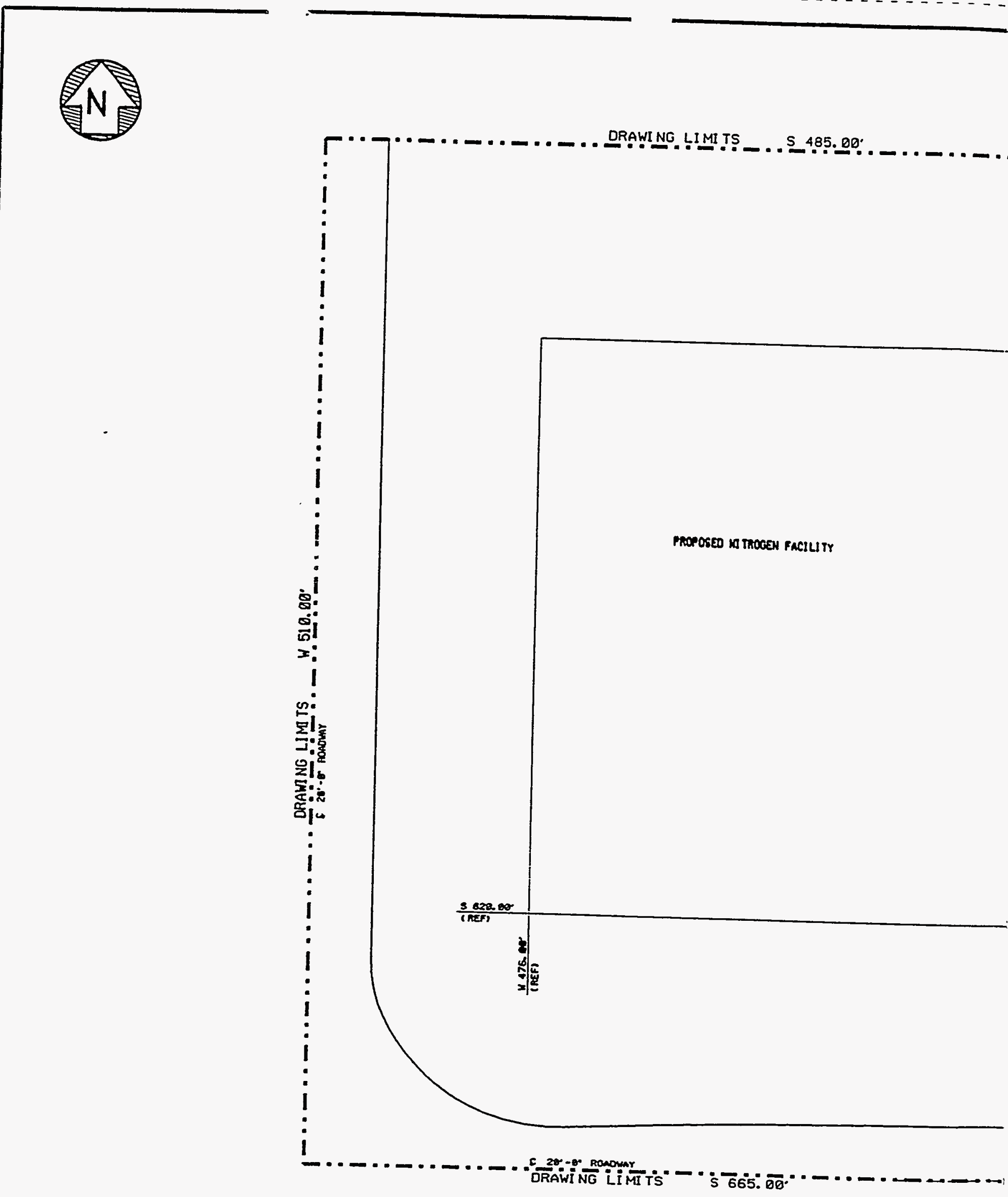

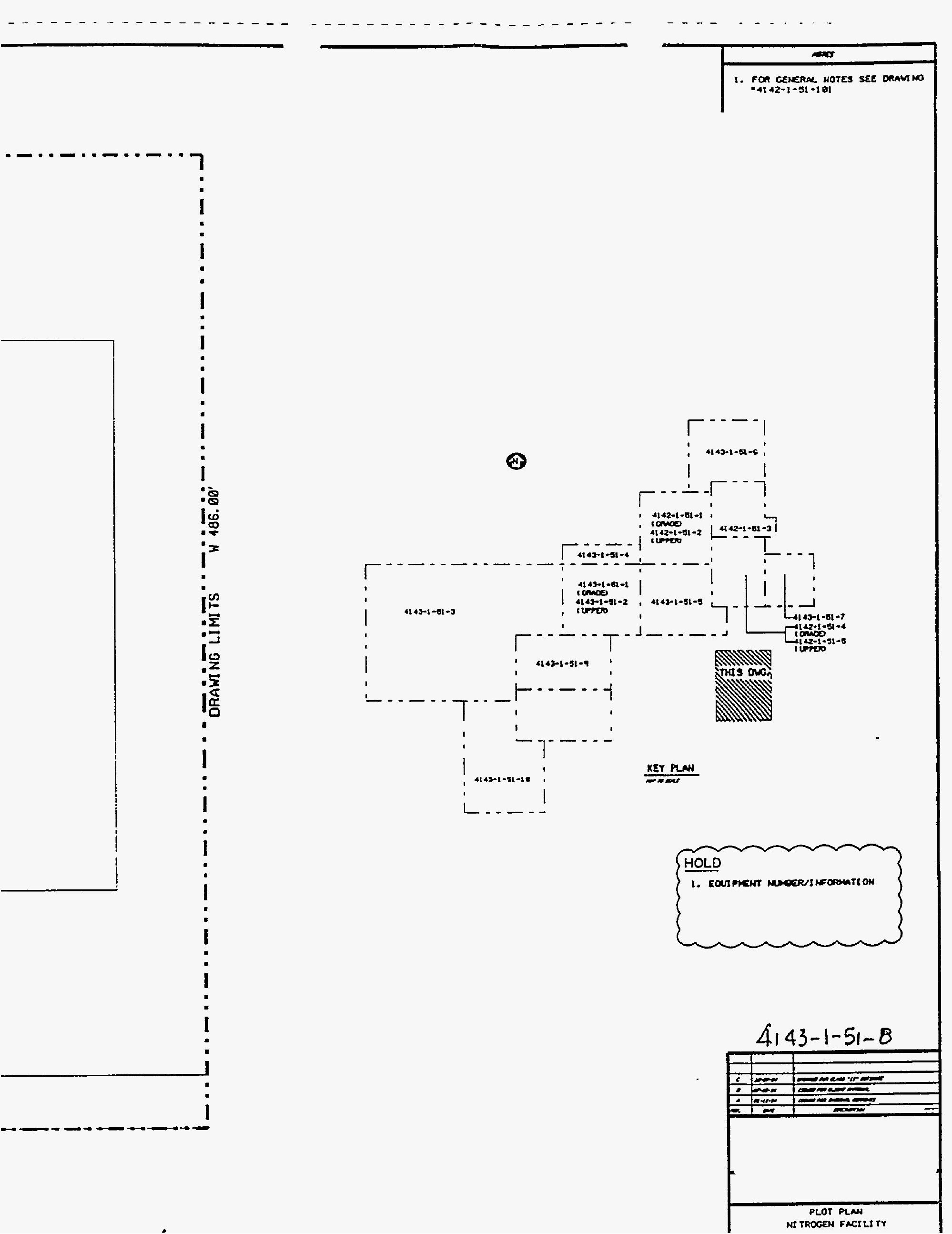


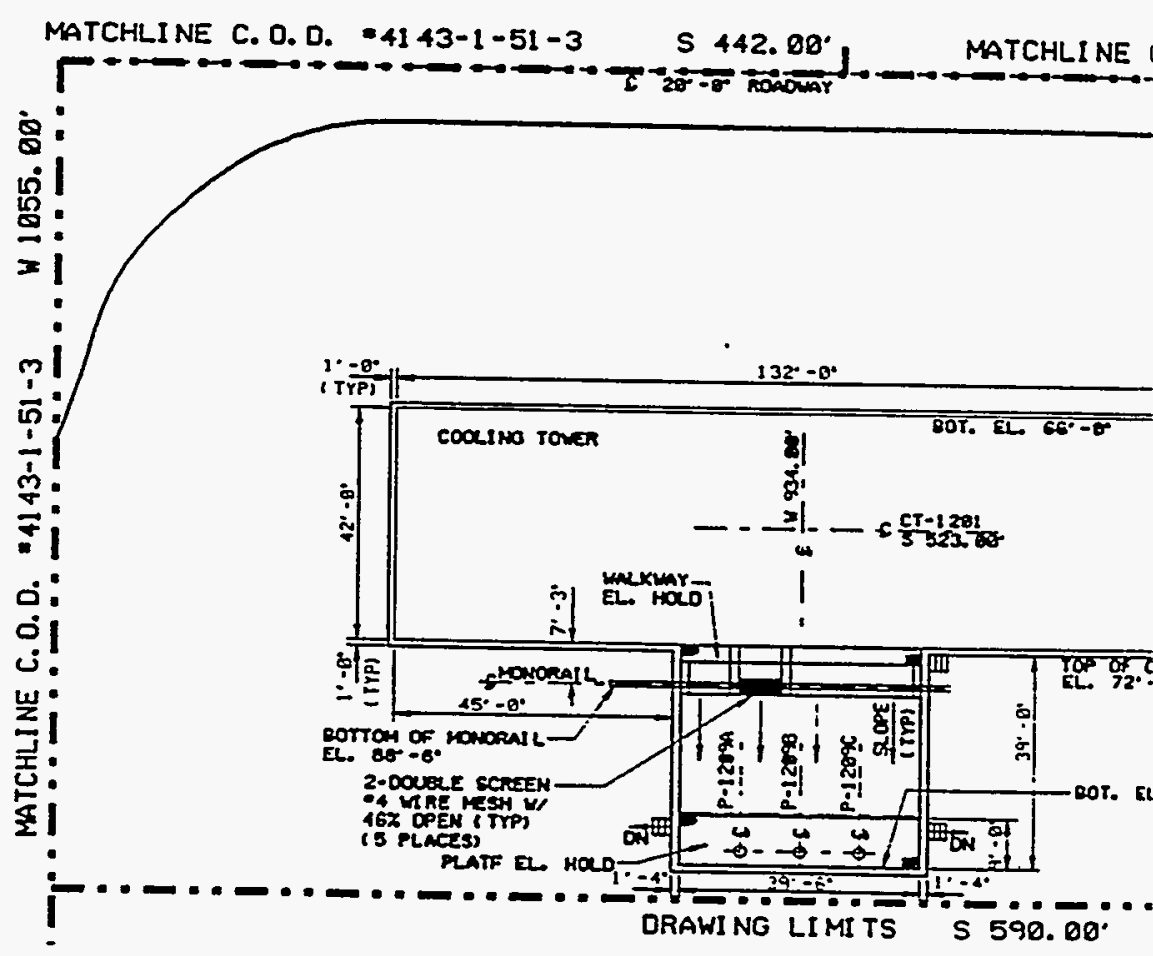


D. $4143-1-51-1$

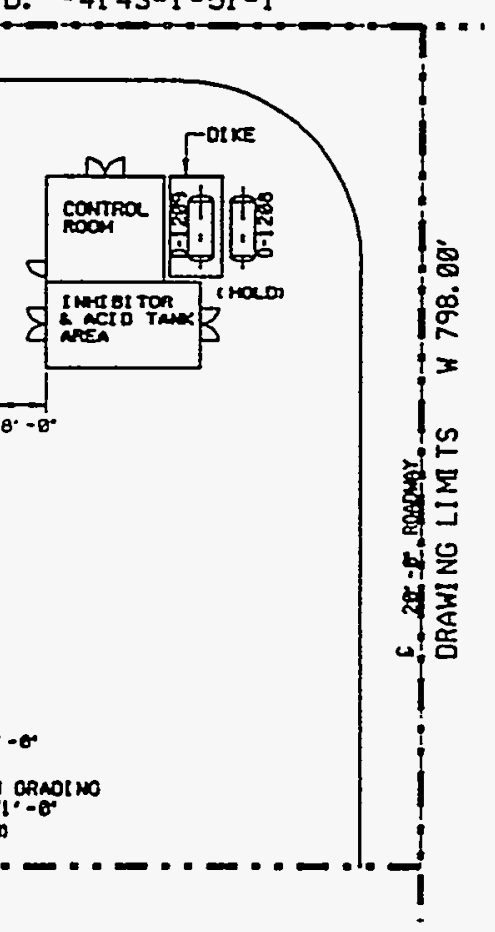

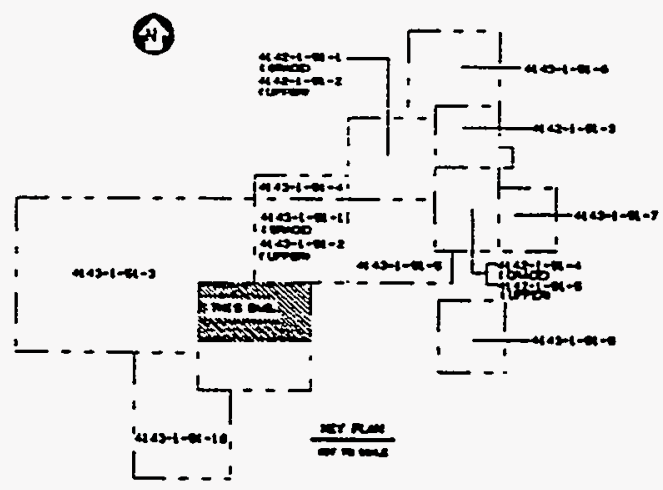
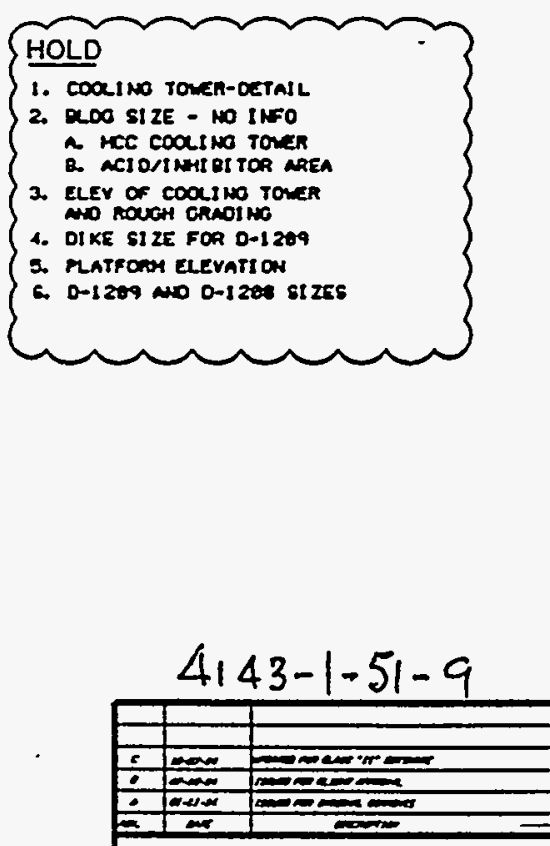
(N)

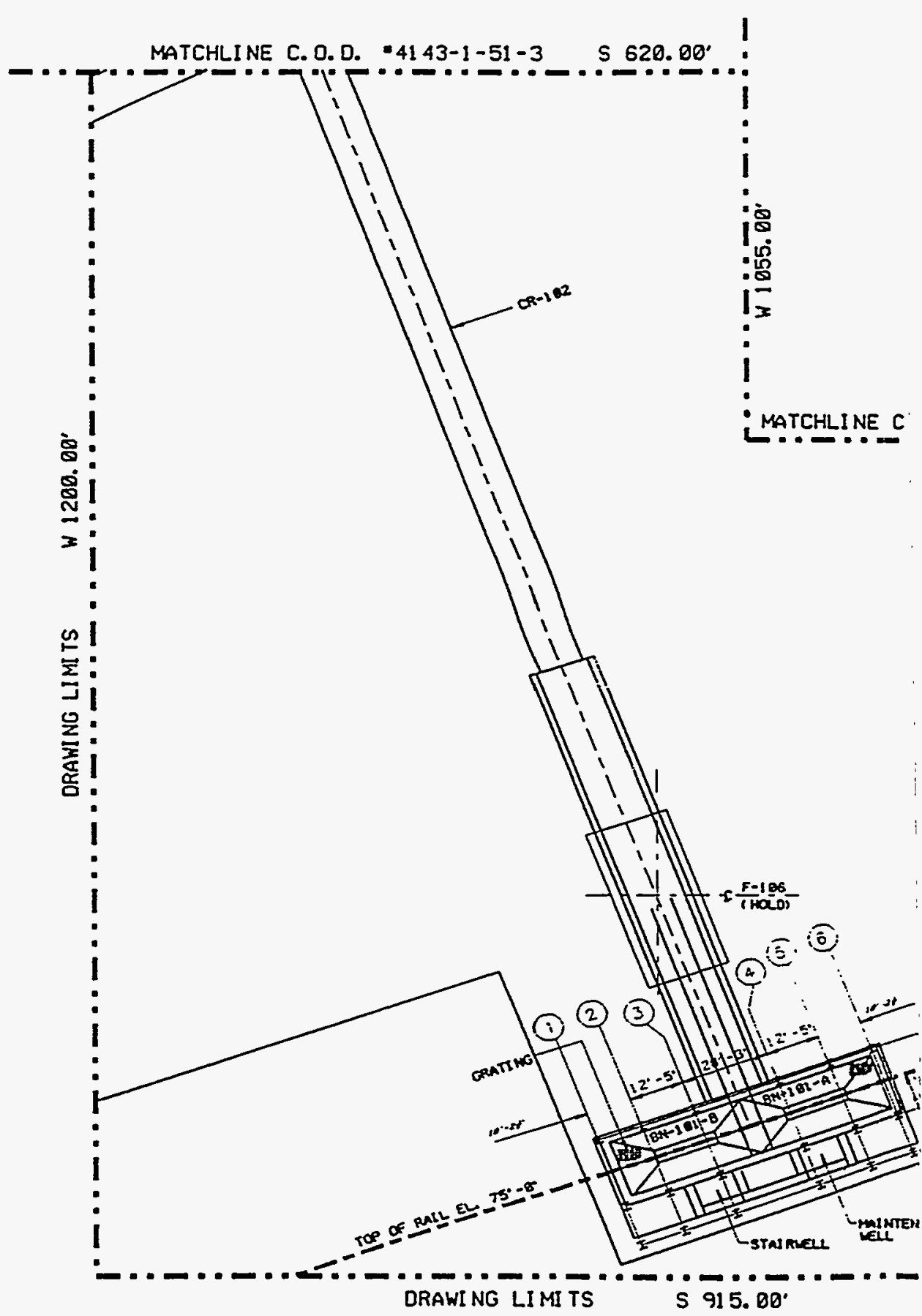




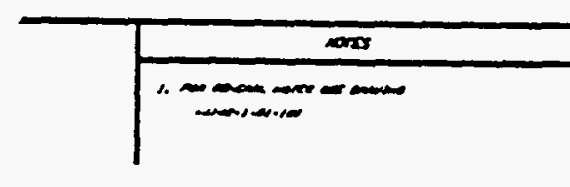

․ㅡ. $=4143-1-51-9.5710 .00$
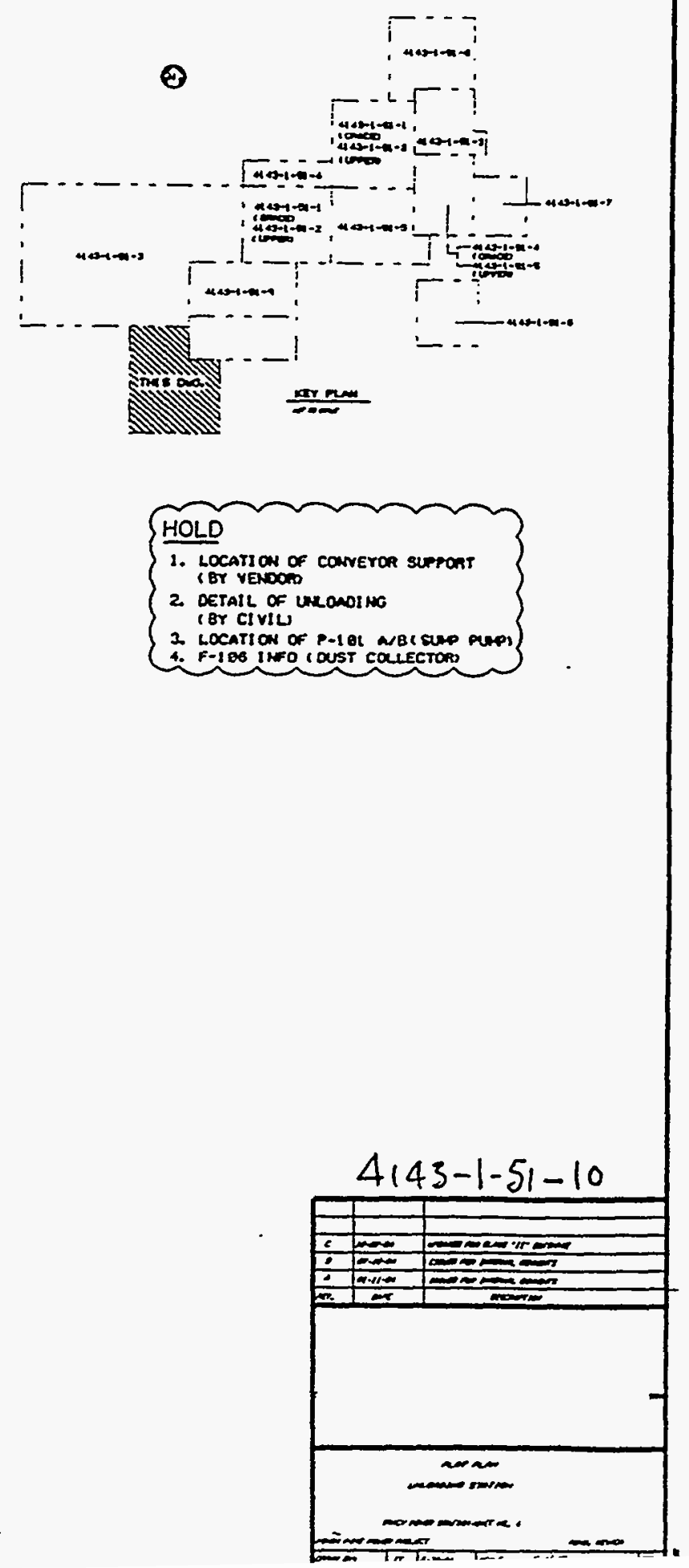
MWKJ-7514

1 OF 20

09 DEC 94

REV. 3

\section{SIERRA PACIFIC POWER COMPANY \\ TRACY 4 - PIÑON PROJECT \\ RENO, NEVADA}

HEAT AND MATERIAL BALANCE - BASE CASE

THE M. W. KELLOGG COMPANY

JOB 7514

\begin{tabular}{|c|c|c|c|c|}
\hline DATE & REV \# & PREP'D & CHECKED & CTE APPR \\
\hline 27 JUL 93 & 0 & FC & GKM & GBH \\
\hline 11 APR 94 & 1 & SN & GKM & GBH \\
\hline 08 JUN 94 & 2 & SN & GKM & GBH \\
\hline OP DéC 94 & 3 & SN & ToD llsum & hH \\
\hline & & & 0 & \\
\hline
\end{tabular}


HEAT AND MATERIAL BALANCE - BASE CASE

UNORIED SUFCO COAL WITH TRANSPORT DESULFURIZER

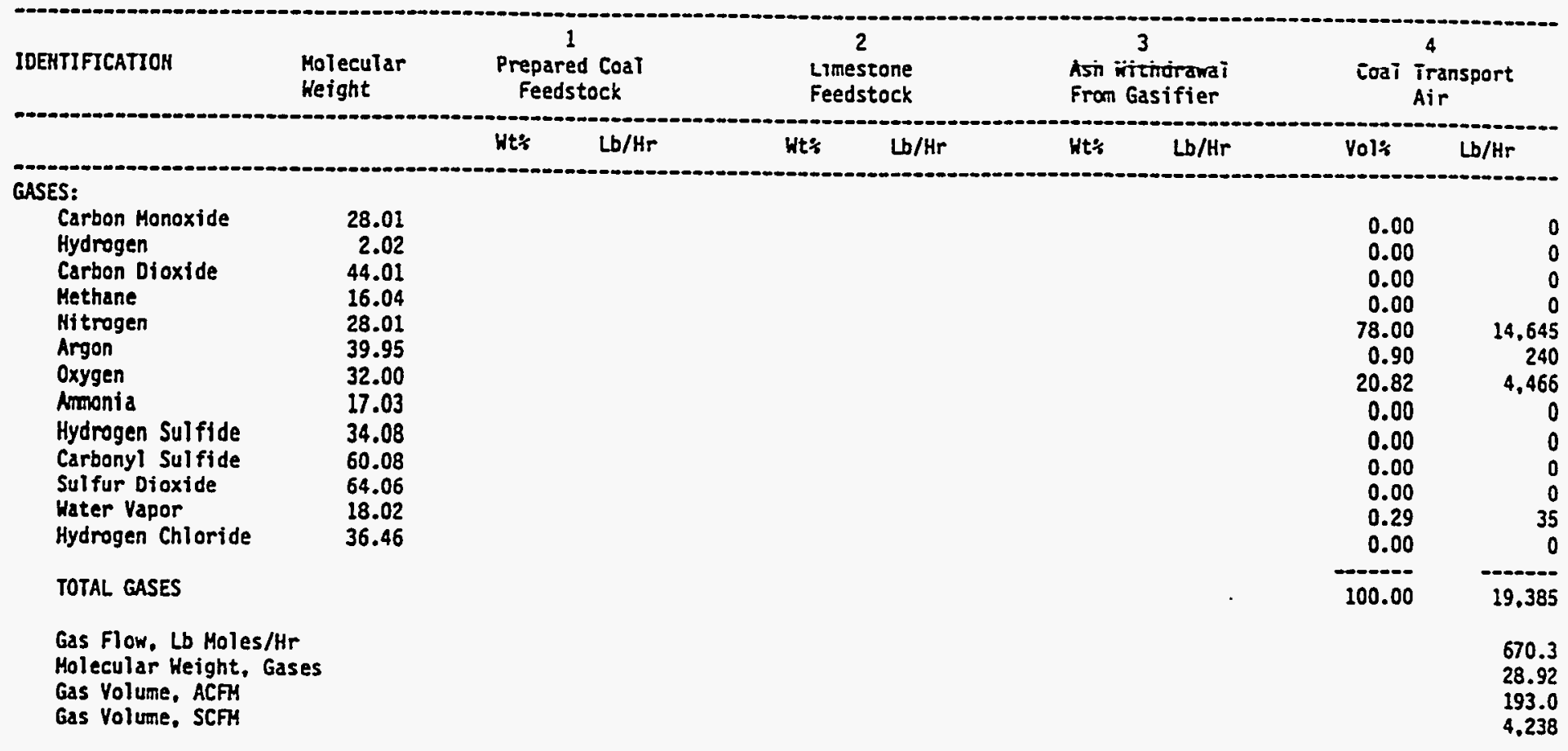

LIQuios:

Nater

SOLIOS:

Carbon

Hydrogen

Oxygen

Nitrogen

Sulfur

Chlorides

Ash

Moisture

TOTAL SOLIOS

SORBEHT:

$\begin{array}{lr}\mathrm{CaO} & 56.08 \\ \mathrm{CaCO} & 100.09 \\ \mathrm{CaS} & 72.14 \\ \mathrm{CaSO} & 136.14 \\ \mathrm{MgO} & 40.31 \\ \mathrm{MgCO} & 84.32 \\ \text { Inerts } & \end{array}$

TOTAL SORBENT

TOTAL FLOH, Lb/Hr
18.02

$\begin{array}{rrr}12.01 & 64.24 & 47.249 \\ 1.01 & 4.33 & 3.187 \\ 16.00 & 10.94 & 8.043 \\ 14.01 & 1.08 & 798 \\ 32.06 & 0.41 & 298 \\ 35.45 & 0.00 & 0 \\ & 9.00 & 6.620 \\ 18.02 & 10.00 & 7.355 \\ & -2 .-. & -. .2 . \\ & 100.00 & 73.550\end{array}$

\begin{tabular}{rr}
27.19 & 1.685 \\
0.07 & 5 \\
0.35 & 22 \\
0.22 & 14 \\
0.17 & 10 \\
0.00 & 0 \\
72.00 & 4.463 \\
0.00 & 0 \\
\hdashline 100.00 & 6.199
\end{tabular}

$$
\begin{array}{r}
0.00 \\
90.04 \\
0.00 \\
0.00 \\
0.00 \\
4.09 \\
5.87 \\
\hline 100.00
\end{array}
$$

73.550

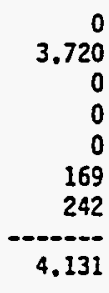

4,131

$$
\begin{array}{r}
74.50 \\
0.00 \\
12.44 \\
0.00 \\
3.26 \\
0.00 \\
9.79 \\
\hdashline 100.00
\end{array}
$$$$
\begin{array}{r}
1.305 \\
0 \\
218 \\
0 \\
57 \\
0 \\
172 \\
\hdashline 1.752
\end{array}
$$

7,951

MEATIHG VALUE:

Gas LHV, Btu/SCF

Gaseous fuel LHV, MHBtu/hr

TEMPERATURE, $F$ PRESSURE, PSIA

\section{0}

13

\section{0}

13
500

310
120

360 
HEAT AND MATERIAL BALANCE - BASE CASE

UNDRIED SUFCO COAL WITH TRANSPORT DESULFURIZER

\begin{tabular}{|c|c|c|c|c|c|c|c|c|c|}
\hline \multirow[t]{2}{*}{ IOEMTIFICAIIOK } & \multirow[t]{2}{*}{$\begin{array}{l}\text { Moiecuiar } \\
\text { Weight }\end{array}$} & \multicolumn{2}{|c|}{$\begin{array}{l}5 \\
\text { Frocess Air } \\
\text { To Gasifier }\end{array}$} & \multicolumn{2}{|c|}{$\begin{array}{c}6 \\
\text { Product Gas } \\
\text { From Gasifier }\end{array}$} & \multicolumn{2}{|c|}{$\begin{array}{c}7 \\
\text { Froduct Eas } \\
\text { From Cyclone }\end{array}$} & \multicolumn{2}{|c|}{$\begin{array}{l}8 \\
\text { Total Air From } \\
\text { Gas Turbine }\end{array}$} \\
\hline & & Vol:s & $\mathrm{Lb} / \mathrm{Hr}$ & Vol\% & $\mathrm{Lb} / \mathrm{Hr}$ & Volt & $\mathrm{Lb} / \mathrm{Hr}$ & Vols & $\mathrm{Lb} / \mathrm{Hr}$ \\
\hline $\begin{array}{l}\text { GASES: } \\
\text { Carbon Honoxide } \\
\text { Hydrogen } \\
\text { Carbon Dioxide } \\
\text { Kethane } \\
\text { Hitrogen } \\
\text { Argon } \\
\text { Oxygen } \\
\text { Amonia } \\
\text { Hydrogen Sul fide } \\
\text { Carbonyl Sul fide } \\
\text { Sulfur Dioxide } \\
\text { Hater Vapor } \\
\text { Hydrogen Chloride }\end{array}$ & $\begin{array}{r}28.01 \\
2.02 \\
44.01 \\
16.04 \\
28.01 \\
39.95 \\
32.00 \\
17.03 \\
34.08 \\
60.08 \\
64.06 \\
18.02 \\
36.46\end{array}$ & $\begin{array}{r}0.00 \\
0.00 \\
0.00 \\
0.00 \\
78.00 \\
0.90 \\
20.82 \\
0.00 \\
0.00 \\
0.00 \\
0.00 \\
0.29 \\
0.00\end{array}$ & $\begin{array}{r}0 \\
0 \\
0 \\
0 \\
145,063 \\
2,379 \\
44,235 \\
0 \\
0 \\
0 \\
0 \\
342 \\
0\end{array}$ & $\begin{array}{r}23.89 \\
14.57 \\
5.44 \\
1.35 \\
48.65 \\
0.56 \\
0.00 \\
0.02 \\
0.03 \\
0.00 \\
0.00 \\
5.50 \\
0.00\end{array}$ & $\begin{array}{r}82.996 \\
3.643 \\
29.708 \\
2.679 \\
169,052 \\
2.760 \\
0 \\
40 \\
127 \\
30 \\
0 \\
12.284 \\
0\end{array}$ & $\begin{array}{r}23.89 \\
14.57 \\
5.44 \\
1.35 \\
48.65 \\
0.56 \\
0.00 \\
0.02 \\
0.03 \\
0.00 \\
0.00 \\
5.50 \\
0.00\end{array}$ & $\begin{array}{r}82,996 \\
3,643 \\
29,708 \\
2,679 \\
169,052 \\
2.760 \\
0 \\
40 \\
127 \\
30 \\
0 \\
12,284 \\
0\end{array}$ & $\begin{array}{r}0.00 \\
0.00 \\
0.00 \\
0.00 \\
78.00 \\
0.90 \\
20.82 \\
0.00 \\
0.00 \\
0.00 \\
0.00 \\
0.29 \\
0.00\end{array}$ & $\begin{array}{r}0 \\
0 \\
0 \\
0 \\
164,042 \\
2.690 \\
50.022 \\
0 \\
0 \\
0 \\
0 \\
387 \\
0\end{array}$ \\
\hline TOTAL GASES & & 100.00 & 192,019 & 100.00 & 303.319 & 100.00 & 303,319 & 100.00 & 217.141 \\
\hline $\begin{array}{l}\text { Gas Flow, Lb Holes } \\
\text { Molecular Weight. } \\
\text { Gas Volume, ACFM } \\
\text { Gas Volume, SCFM }\end{array}$ & & & $\begin{array}{r}6639.3 \\
28.92 \\
3660.0 \\
41,977\end{array}$ & & $\begin{array}{r}12404.2 \\
24.45 \\
16992.1 \\
78,425\end{array}$ & & $\begin{array}{r}12404.2 \\
24.45 \\
17166.6 \\
78,425\end{array}$ & & $\begin{array}{r}7.508 .0 \\
28.92 \\
10067.6 \\
47,469\end{array}$ \\
\hline
\end{tabular}

LIQUIDS:

Water

SOLIDS:

Carbon

Hydrogen

Oxygen

Mitrogen

Sulfur

Chiorides

Ash

Moisture

18.02

TOTAL SOLIDS

SORBEHT:

$\begin{array}{lr}\mathrm{CaO} & 56.08 \\ \mathrm{CaCO} & 100.09 \\ \mathrm{CaS} & 72.14 \\ \mathrm{CaSO} & 136.14 \\ \mathrm{MgO} & 40.31 \\ \mathrm{MgCO} & 84.32\end{array}$

Inerts

TOTAL SORBEHT

TOTAL FLOW, Lb/Hr

HEATING VALUE:

GaS LHV. Btu/SCF

Gaseous Fuel LHV, MBtu/hr

16.00

32.06

18.02

-.--ons Fuel LHN, Mutu/hr

TEMPERATURE, $F$

PRESSURE, PSIA

\subsection{1 \\ 1.01 \\ 14.01 \\ 35.45}

Wt:

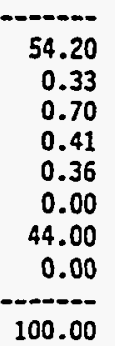

74.50

$$
\begin{array}{r}
0.00 \\
12.44
\end{array}
$$

0.00

3.26

0.00

9.79

100.00

\begin{tabular}{|c|c|c|}
\hline & Wt: & \\
\hline $\begin{array}{r}45.794 \\
275 \\
591 \\
345 \\
308\end{array}$ & $\begin{array}{r}54.20 \\
0.33 \\
0.70 \\
0.41 \\
0.36\end{array}$ & $\begin{array}{r}2.656 \\
16 \\
34 \\
20 \\
18\end{array}$ \\
\hline 0 & 0.00 & 0 \\
\hline 37,174 & 44.00 & 2,156 \\
\hline 0 & 0.00 & 0 \\
\hline 84,487 & 100.00 & 4.900 \\
\hline
\end{tabular}

26,976

0
4,505

1,181

0
3.546

-...-...

36.209

424.015

\begin{tabular}{rr}
74.50 & 539 \\
0.00 & 0 \\
12.44 & 90 \\
0.00 & 0 \\
3.26 & 24 \\
0.00 & 0 \\
9.79 & 71 \\
\hdashline 100.00 & 724 \\
& 308.943
\end{tabular}

217.141

129
607.4

607.4

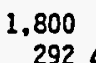

295

292 
HEAT AND MATERIAL BALANCE - BASE CASE UHORIEO SUFCO COAL HITH TRANSPORT DESULFURIZER

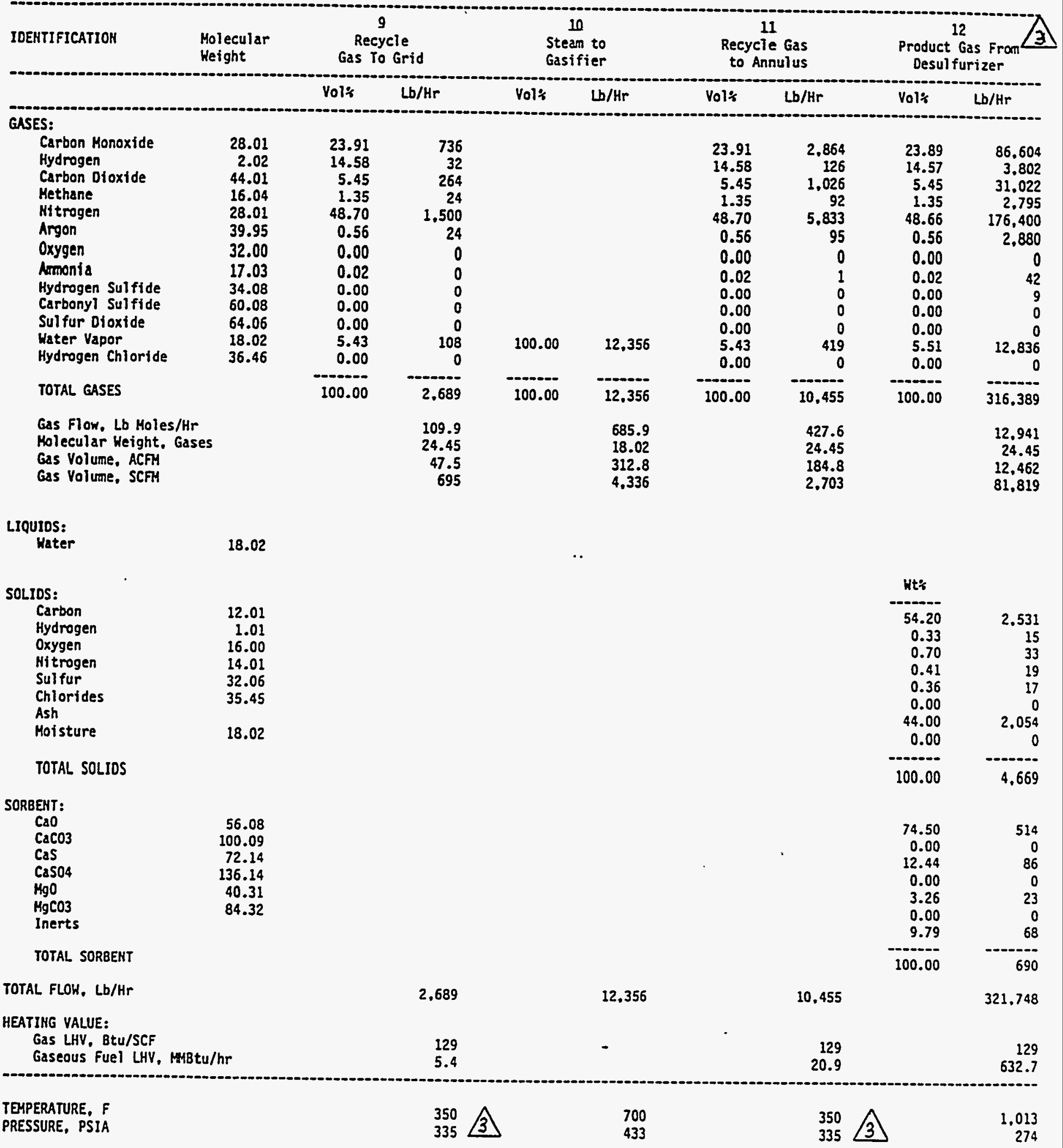


HEAT AND MATERIAL BALAHCE - BASE CASE UNDRIED SUFCO COAL WITH TRANSPORT DESULFURIZER

\begin{tabular}{|c|c|c|c|c|c|c|c|c|c|}
\hline \multirow[t]{2}{*}{ IDEHTIFICATION } & \multirow[t]{2}{*}{$\begin{array}{l}\text { Holecular } \\
\text { Weight }\end{array}$} & \multicolumn{2}{|c|}{$\begin{array}{l}\text { Condensate From } \\
\text { Recycle Gas }\end{array}$} & \multicolumn{2}{|c|}{$\begin{array}{l}\text { Blowback Gas } \\
\text { to Filter }\end{array}$} & \multicolumn{2}{|c|}{$\begin{array}{l}\text { Recycle Gas To } \\
\text { RG Booster Comp. }\end{array}$} & \multicolumn{2}{|c|}{$\begin{array}{l}\text { Pressurization } \\
\text { Recycle Gas }\end{array}$} \\
\hline & & Wt: & $\mathrm{Lb} / \mathrm{Hr}$ & Vols & $\mathrm{Lb} / \mathrm{Hr}$ & Vols: & $\mathrm{Lb} / \mathrm{Hr}$ & Volt: & $\mathrm{Lb} / \mathrm{Hr}$ \\
\hline $\begin{array}{l}\text { GASES: } \\
\text { Carbon Honoxide } \\
\text { Hydrogen } \\
\text { Carbon Dioxide } \\
\text { Methane } \\
\text { Mitrogen } \\
\text { Argon } \\
\text { Oxygen } \\
\text { Aruonia } \\
\text { Hydrogen Sulfide } \\
\text { Carbonyl Sulfide } \\
\text { Sulfur Dioxide } \\
\text { Hater Vapor } \\
\text { Hydrogen Chloride }\end{array}$ & $\begin{array}{r}28.01 \\
2.02 \\
44.01 \\
16.04 \\
28.01 \\
39.95 \\
32.00 \\
17.03 \\
34.08 \\
60.08 \\
64.06 \\
18.02 \\
36.46\end{array}$ & & & $\begin{array}{r}25.21 \\
15.37 \\
5.75 \\
1.42 \\
51.34 \\
0.59 \\
0.00 \\
0.02 \\
0.00 \\
0.00 \\
0.00 \\
0.30 \\
0.00\end{array}$ & $\begin{array}{r}1266 \\
56 \\
454 \\
41 \\
2579 \\
42 \\
0 \\
1 \\
0 \\
0 \\
0 \\
10 \\
0\end{array}$ & $\begin{array}{r}25.21 \\
15.37 \\
5.75 \\
1.42 \\
51.34 \\
0.59 \\
0.00 \\
0.02 \\
0.00 \\
0.00 \\
0.00 \\
0.30 \\
0.00\end{array}$ & $\begin{array}{r}1,444 \\
63 \\
517 \\
47 \\
2.940 \\
48 \\
0 \\
1 \\
0 \\
0 \\
0 \\
11 \\
0\end{array}$ & $\begin{array}{r}25.21 \\
15.37 \\
5.75 \\
1.42 \\
51.34 \\
0.59 \\
0.00 \\
0.02 \\
0.00 \\
0.00 \\
0.00 \\
0.30 \\
0.00\end{array}$ & $\begin{array}{r}177 \\
8 \\
63 \\
6 \\
361 \\
6 \\
0 \\
0 \\
0 \\
0 \\
0 \\
1 \\
0\end{array}$ \\
\hline TOTAL GASES & & & & 100.00 & 4,448 & 100.00 & 5,071 & 100.00 & 622 \\
\hline $\begin{array}{l}\text { Gas Flow, Lb Holes } \\
\text { Holecular Height, } \\
\text { Gas Volume, ACFM } \\
\text { Gas Volume. SCFM }\end{array}$ & ses & & & & $\begin{array}{r}179.3 \\
24.80 \\
18.4 \\
1.134\end{array}$ & & $\begin{array}{r}204.4 \\
24.80 \\
80.5 \\
1.293\end{array}$ & & $\begin{array}{r}25.1 \\
24.80 \\
5.5 \\
159\end{array}$ \\
\hline $\begin{array}{l}\text { LIQUIOS: } \\
\text { Water }\end{array}$ & 18.02 & 100.00 & 200 & & & & & & \\
\hline
\end{tabular}

SOLIOS:

$\begin{array}{lr}\text { Carbon } & 12.01 \\ \text { Hydrogen } & 1.01 \\ \text { Oxygen } & 16.00 \\ \text { Hitrogen } & 14.01 \\ \text { Sulfur } & 32.06 \\ \text { Chlorides } & 35.45 \\ \text { Ash } & \\ \text { Moisture } & 18.02\end{array}$

TOTAL SOLIDS

SORBEHT:

$\begin{array}{lr}\mathrm{CaO} & 56.08 \\ \mathrm{CaCO} & 100.09 \\ \mathrm{CaS} & 72.14 \\ \mathrm{CaSO} & 136.14 \\ \mathrm{HgO} & 40.31 \\ \mathrm{HgCO} & 84.32\end{array}$

Inerts

TOTAL SORBEHT

TOTAL FLOH, Lb/Hr

HEATING VALUE:

Gas LHV, Btu/SCF

Gaseous fuel LHV, w8tu/hr

136

136

10.5

Hote 1: Streams 14 and 16 are time averaged flow rates.

Stream 14 also includes $1200 \mathrm{lb} / \mathrm{hr}$ instrument purge flow. 
HEAT AHD MATERIAL BALAHCE - BASE CASE

ORIED SUFCO COAL WITH TRAHSPORT DESULFURIZER

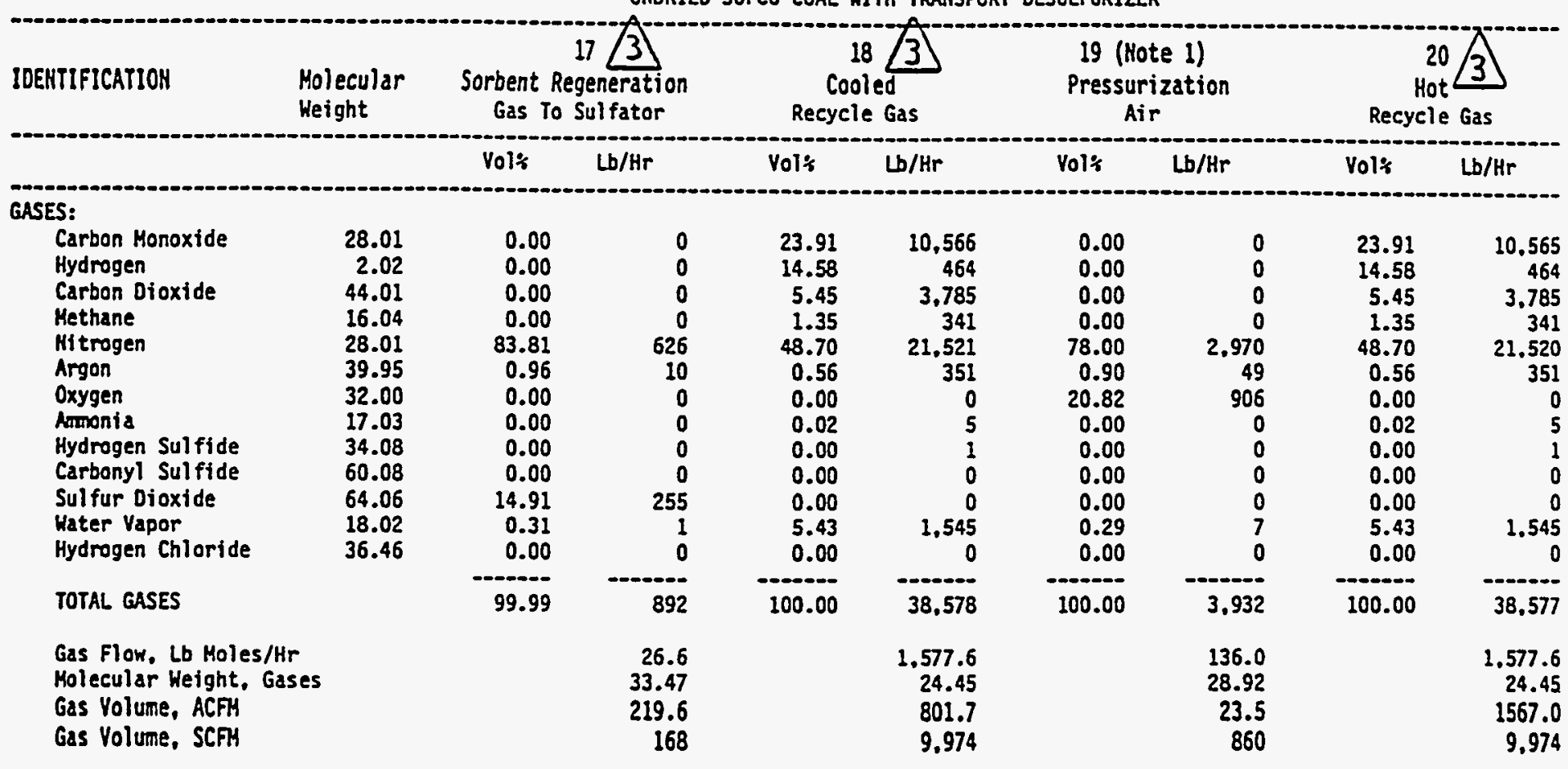

LIQUIOS:

Hater

SOLIDS:

$\begin{array}{lr}\text { Carbon } & 12.01 \\ \text { Hydragen } & 1.01 \\ \text { Oxygen } & 16.00 \\ \text { Hitrogen } & 14.01 \\ \text { Sulfur } & 32.06 \\ \text { Chlorides } & 35.45 \\ \text { Ash } & \\ \text { Moisture } & 18.02\end{array}$

TOTAL SOLIDS

SORBEHT:

$\begin{array}{lr}\mathrm{CaO} & 56.08 \\ \mathrm{CaCO} & 100.09 \\ \mathrm{CaS} & 72.14 \\ \mathrm{CaSO} 4 & 136.14 \\ \mathrm{MgO} & 40.31 \\ \mathrm{MgCO3} & 84.32\end{array}$

Inerts

TOTAL SORBENT

TOTAL FLOW, Lb/Hr

892

38,578

3.932

$38,57 i$

HEATIMG VALUE:

Gas LHV, Btu/SCF

Gaseous fuel LHV. MBtu/hr

129

77.2

725

TEMPERATURE, $F$ PRESSURE, PSIA

\section{0}

23
270

257
120

600
464

3.785

1.520

351

5

545

8,577

. 45

9.974

Note 1: Stream 19 is a time averaged flow rate. 
HEAT ANO MATERIAL BALANICE - BASE CASE UHDRIED SUFCO COAL WITH TRAHSPORT DESULFURIZER

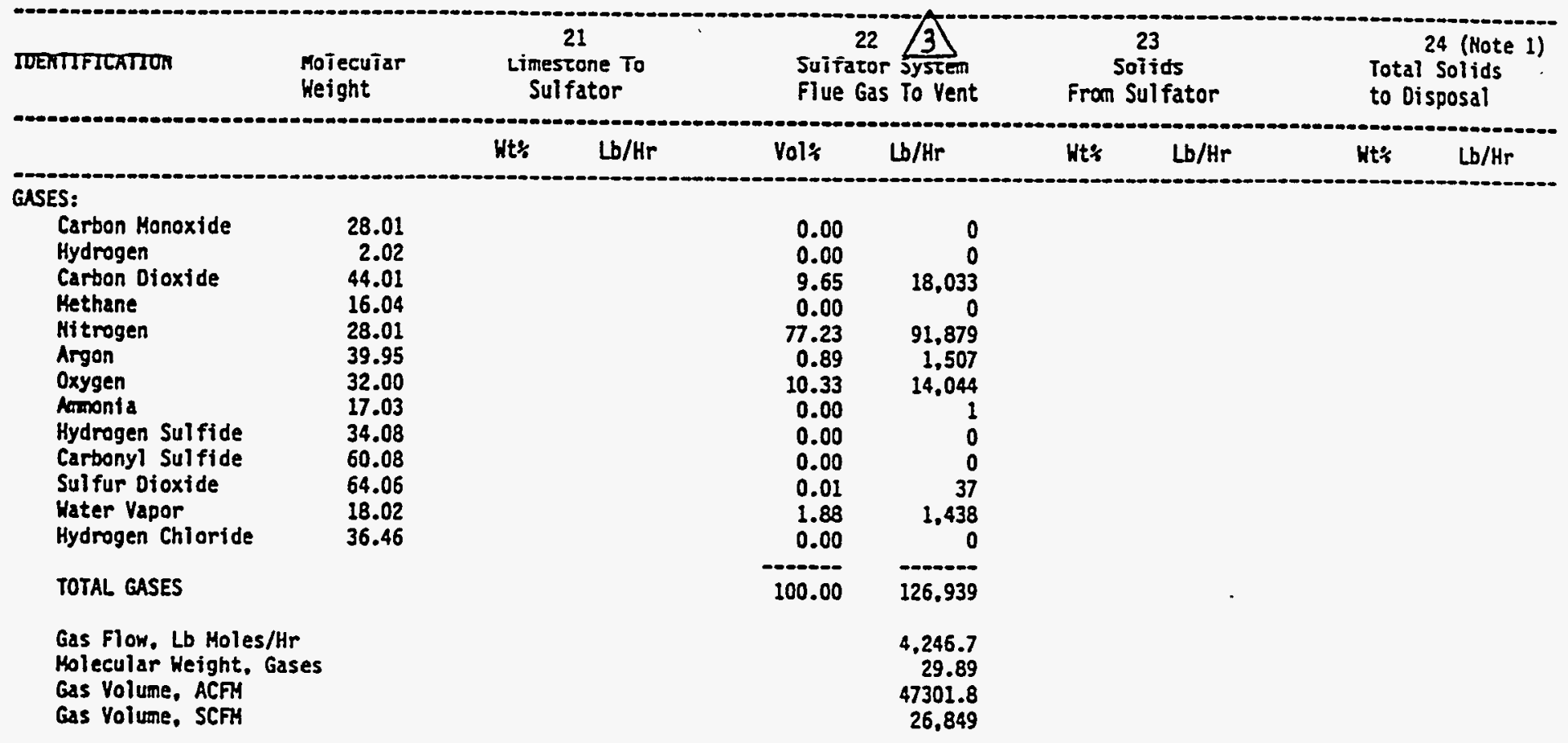

\section{LIQU10S:}

Nater

SOLIOS:

Carbon 12.0

Hydrogen 1.01

Oxygen 16.00

Nitrogen $\quad 14.01$

Sulfur $\quad 32.06$

Chlorides $\quad 35.45$

Ash

Moisture $\quad 18.02$

TOTAL SOLIDS

SORBENT:

$\begin{array}{lr}\mathrm{CaO} & 56.08 \\ \mathrm{CaCO} & 100.09 \\ \mathrm{CaS} & 72.14 \\ \mathrm{CaSO} & 136.14 \\ \mathrm{MgO} & 40.31 \\ \mathrm{MgCO} & 84.32 \\ \text { Inerts } & \end{array}$

TOTAL SORBENT

TOTAL FLOH, Lb/Hr

HEATIHG VALUE:

Gas LHV, Btu/SCF

Gaseous fuel LHV, MBtu/hr
8.02
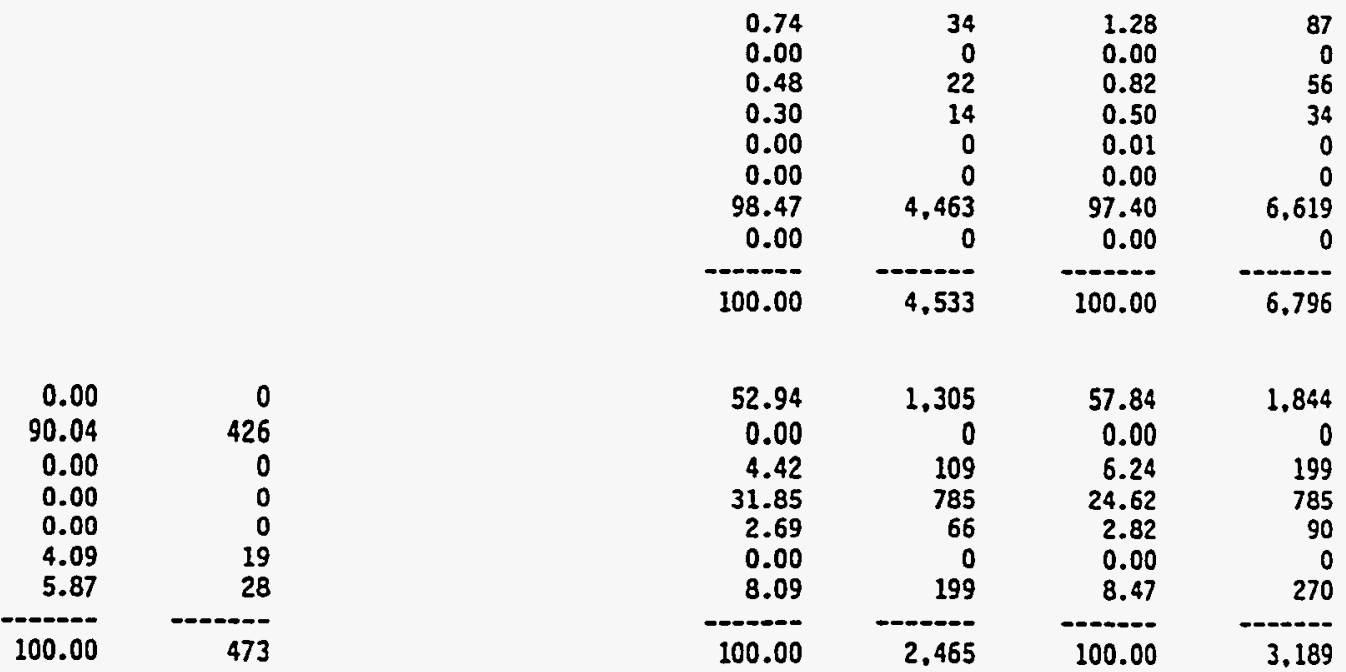

1,305

57.84

6.24

24.62

2.82

0.00

8.47

100.00

126,939

6.998

9.985
TEYPERATURE, $F$ PRESSURE, PSIA

50

20
350

13
1,600

17

Hote 1: Temperature of stream 24 is calculated by biending strean 64 with the cooled sulfator solids stream. 
HEAT AND MATERIAL BALANCE - BASE CASE UNDRIED SUFCO COAL HITH TRAHSPORT DESULFURIZER

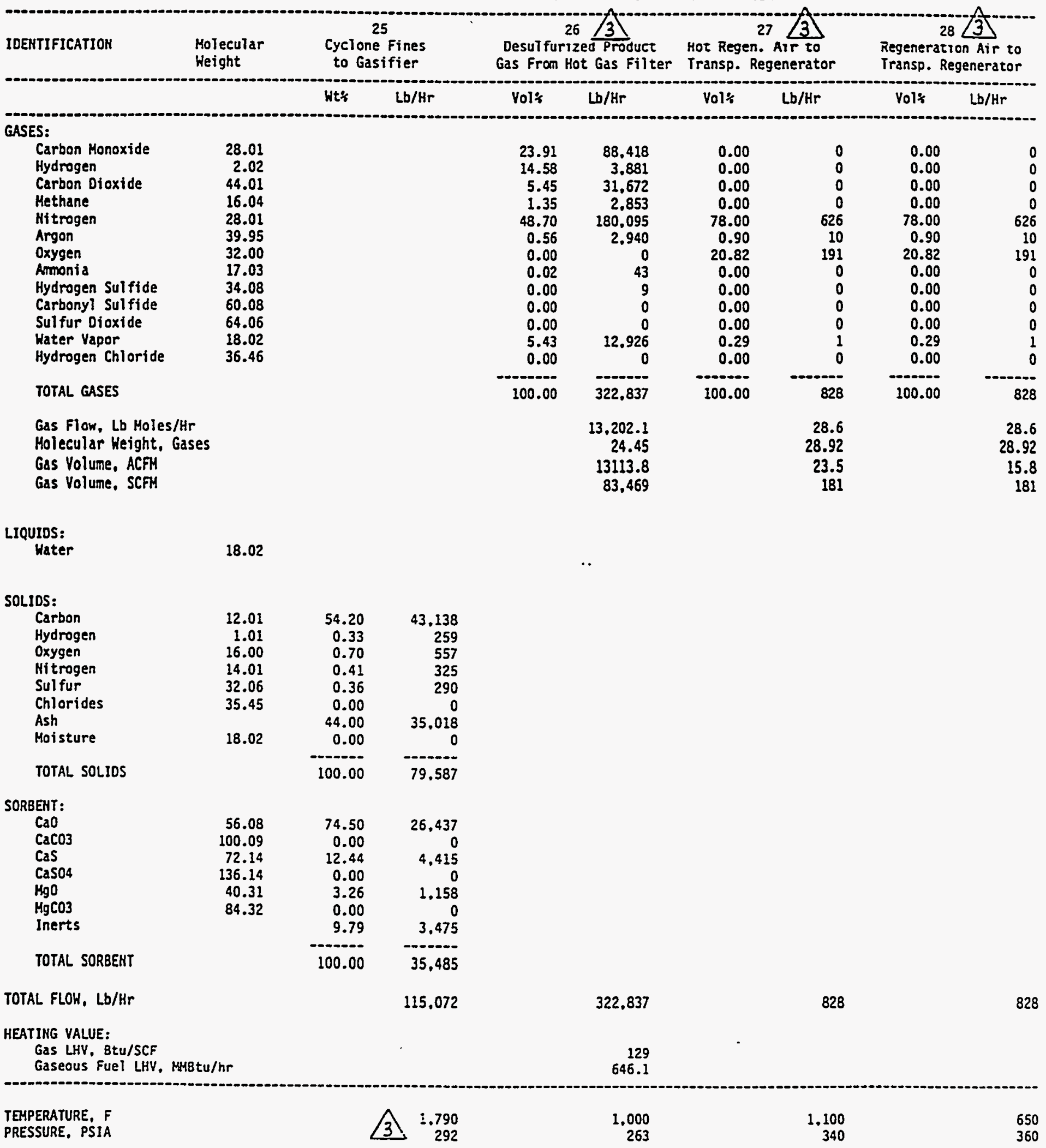


HEAT AMD MATERIAL BALANCE - BASE CASE UNORIED SUFCO COAL WITH TRANSPORT DESULFURIZER

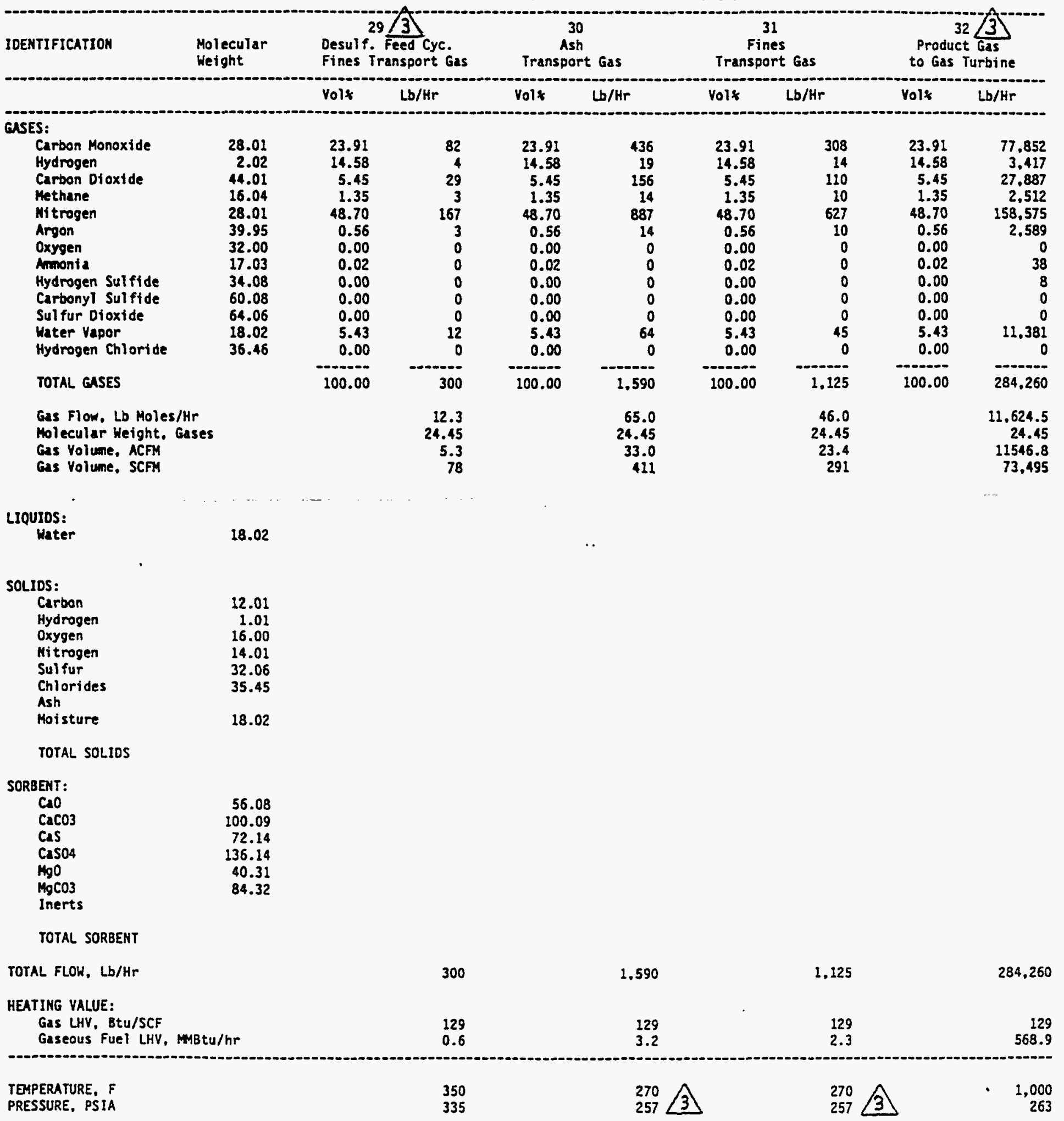


HEAT NWD MATERIAL BALANCE - BASE CASE

UNDRIED SUFCO COAL WITH TRANSPORT DESULFURIZER

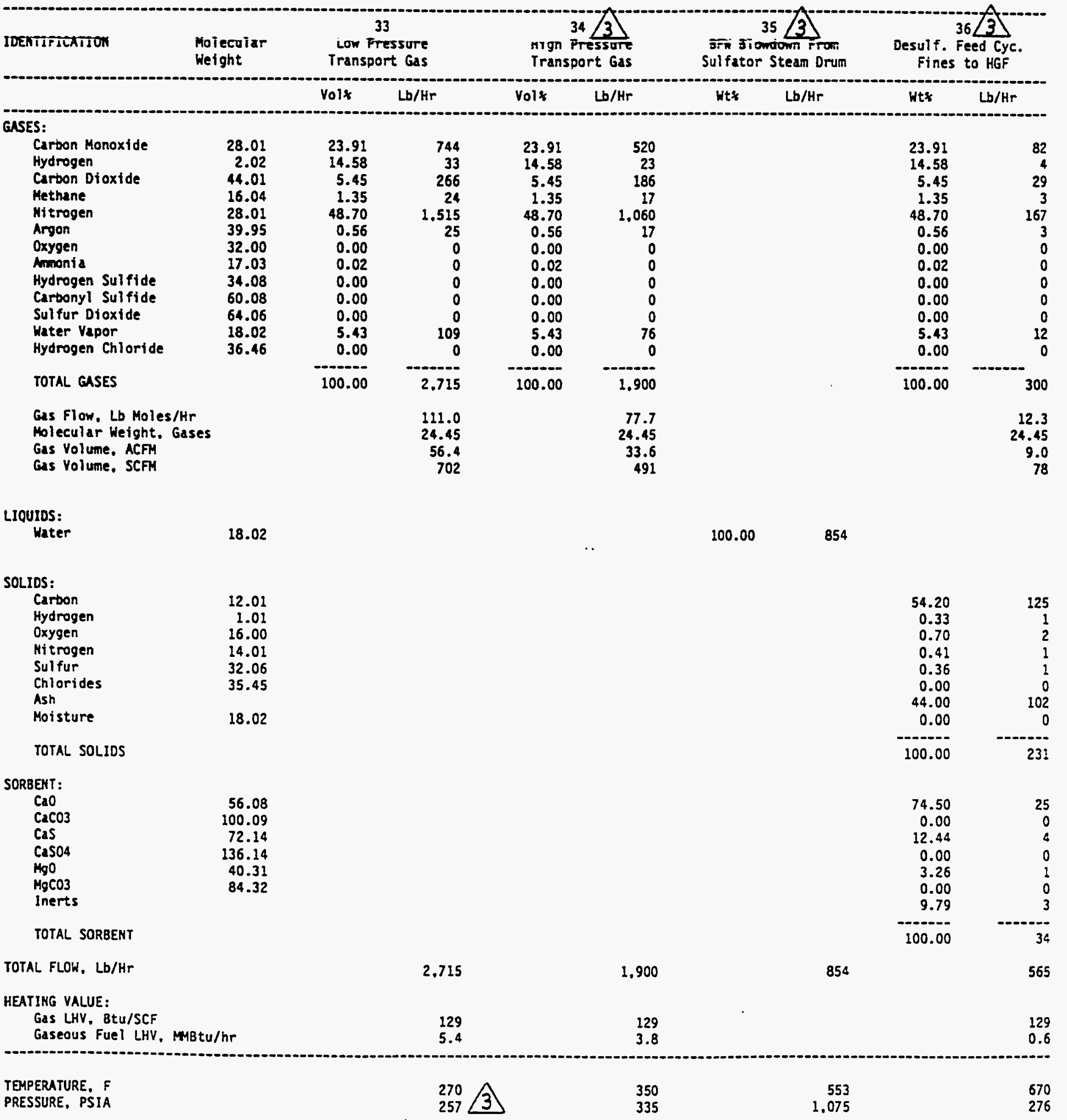


HEAT AND MATERIAL BALANCE - BASE CASE

UNORIED SUFCO COAL WITH TRAKSPORT OESULFURIZER

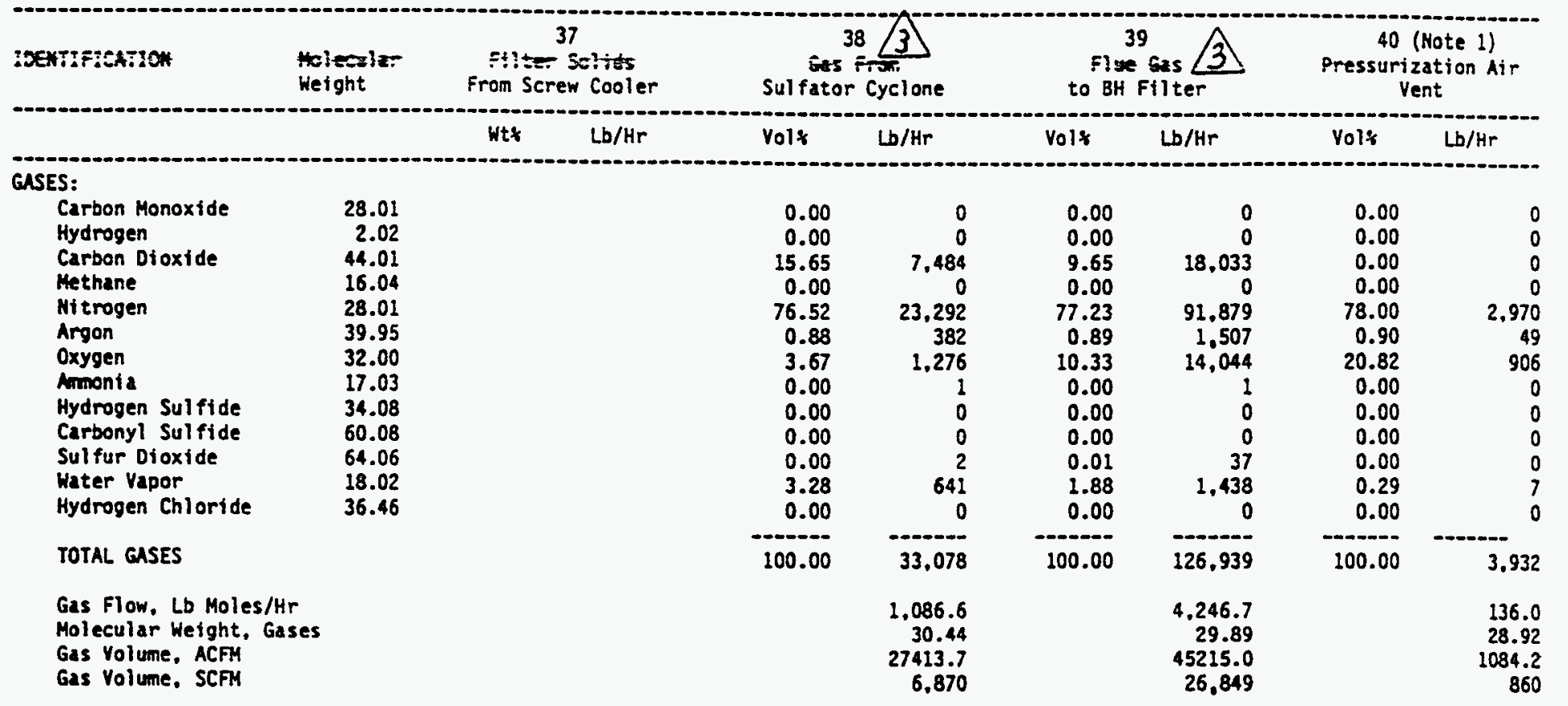

\section{LIQUIDS:}

Water

SOLIDS:

Carbon

Hydrogen

Oxygen

Nitrogen

Sulfur

Chlorides

Ash

Moisture

TOTAL SOLIOS

SORBENT:

CaO

$\mathrm{CaCO} 3$

Cas

$\mathrm{CaSO}_{4}$

$\mathrm{MgO}$

$\mathrm{MgCO} 3$

Inerts

TOTAL SORBENT

TOTAL FLOW, Lb/Hr
18.02

$$
\begin{array}{r}
12.01 \\
1.01 \\
16.00 \\
14.01 \\
32.06 \\
35.45 \\
18.02
\end{array}
$$

$\begin{array}{r}54.20 \\ 0.33 \\ 0.70 \\ 0.41 \\ 0.36 \\ 0.00 \\ 44.00 \\ 0.00 \\ \hdashline 100.00\end{array}$

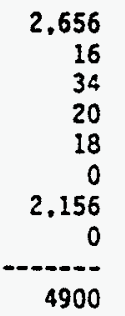

56.08

100.09

72.14

136.14

40.31

84.32

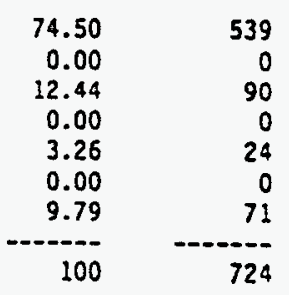

5.624
Wt*
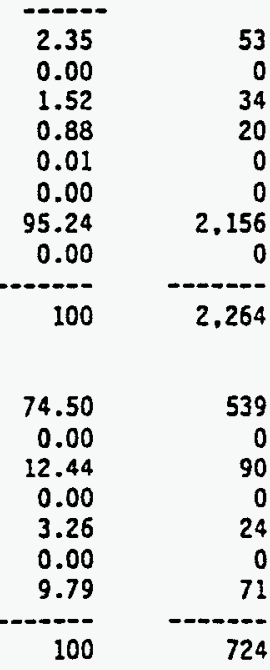

33,078

129.926

heATING VALUE:

Gas LHV. Btu/SCF

Gaseous Fuel LHV, MBtu/hr

TEMPERATURE, $F$

PRESSURE, PSIA
500

263

Note 1 : Time averaged flow. 
HEAT AND MATERIAL BALANCE - BASE CASE

UKDRIED SUFCO COAL WITH TRAKSPORT DESULFURIZER

\begin{tabular}{|c|c|c|c|c|c|c|c|c|c|}
\hline \multirow[t]{2}{*}{ IDERTIFICATIOR } & \multirow[t]{2}{*}{$\begin{array}{l}\text { Molecular } \\
\text { Height }\end{array}$} & \multicolumn{2}{|c|}{$\begin{array}{l}\text { Total BFW } \\
\text { From Sec. } 800\end{array}$} & \multicolumn{2}{|c|}{$\begin{array}{l}\quad 42 \\
\text { Recycle Gas } \\
\text { To Gasifier }\end{array}$} & \multicolumn{2}{|c|}{$\begin{array}{l}43 \text { (Note 1) } \\
\text { Ash Hopper } 13 \\
\text { Vent Gas }\end{array}$} & \multicolumn{2}{|c|}{$\begin{array}{c}44 \text { (Note } 1 \text { ) } \\
\text { Fines Hopper } \\
\text { Vent Gas } 3\end{array}$} \\
\hline & & Wts & $\mathrm{Lb} / \mathrm{Hr}$ & Volt & $\mathrm{Lb} / \mathrm{Hr}$ & Volf & $\mathrm{Lb} / \mathrm{Hr}$ & Volt & $\mathrm{Lb} / \mathrm{Hr}$ \\
\hline $\begin{array}{l}\text { GASES: } \\
\text { Carbon Monoxide } \\
\text { Hydrogen } \\
\text { Carbon Dioxide } \\
\text { Methane } \\
\text { Nitrogen } \\
\text { Argon } \\
\text { Oxygen } \\
\text { Armonia } \\
\text { Hydrogen Sulfide } \\
\text { Carbonyl Sulfide } \\
\text { Sulfur Dioxide } \\
\text { Water Vapor } \\
\text { Hydrogen Chloride }\end{array}$ & $\begin{array}{r}28.01 \\
2.02 \\
44.01 \\
16.04 \\
28.01 \\
39.95 \\
32.00 \\
17.03 \\
34.08 \\
60.08 \\
64.06 \\
18.02 \\
36.46\end{array}$ & & & $\begin{array}{r}23.91 \\
14.58 \\
5.45 \\
1.35 \\
48.70 \\
0.56 \\
0.00 \\
0.02 \\
0.00 \\
0.00 \\
0.00 \\
5.43 \\
0.00\end{array}$ & $\begin{array}{r}4,231 \\
186 \\
1,516 \\
137 \\
8,618 \\
141 \\
0 \\
2 \\
0 \\
0 \\
0 \\
619 \\
0\end{array}$ & $\begin{array}{r}25.21 \\
15.37 \\
5.75 \\
1.42 \\
51.34 \\
0.59 \\
0.00 \\
0.02 \\
0.00 \\
0.00 \\
0.00 \\
0.30 \\
0.00\end{array}$ & $\begin{array}{r}50 \\
2 \\
18 \\
2 \\
102 \\
2 \\
0 \\
0 \\
0 \\
0 \\
0 \\
0 \\
0\end{array}$ & $\begin{array}{r}25.21 \\
15.37 \\
5.75 \\
1.42 \\
51.34 \\
0.59 \\
0.00 \\
0.02 \\
0.00 \\
0.00 \\
0.00 \\
0.30 \\
0.00\end{array}$ & $\begin{array}{r}127 \\
6 \\
45 \\
4 \\
259 \\
4 \\
0 \\
0 \\
0 \\
0 \\
0 \\
1 \\
0\end{array}$ \\
\hline TOTAL GASES & & & & 100.00 & 15,448 & 100.00 & 176 & 100.00 & 446 \\
\hline \multicolumn{2}{|c|}{$\begin{array}{l}\text { Gas Flow. Lb Moles/Hr } \\
\text { Molecular Weight, Gases } \\
\text { Gas Volume. ACFM } \\
\text { Gas Volume. SCFM }\end{array}$} & & & & $\begin{array}{l}631.7 \\
24.45 \\
273.1 \\
3,994\end{array}$ & & $\begin{array}{r}7.1 \\
24.80 \\
2.8 \\
45\end{array}$ & & $\begin{array}{r}18.0 \\
24.80 \\
8.4 \\
114\end{array}$ \\
\hline \multicolumn{10}{|l|}{ LIQUIOS: } \\
\hline $\begin{array}{l}\text { SOLIDS: } \\
\text { Carbon } \\
\text { Hydrogen } \\
\text { Oxygen } \\
\text { Nitrogen } \\
\text { Sulfur } \\
\text { Chlorides } \\
\text { Ash } \\
\text { Moisture }\end{array}$ & $\begin{array}{r}12.01 \\
1.01 \\
16.00 \\
14.01 \\
32.06 \\
35.45 \\
18.02\end{array}$ & & & & & & & & \\
\hline \multicolumn{10}{|l|}{ TOTAL SOLIDS } \\
\hline $\begin{array}{l}\text { SORBENT: } \\
\mathrm{CaO} \\
\mathrm{CaCO} \\
\mathrm{CaS} \\
\mathrm{CaSO} 4 \\
\mathrm{MgO} \\
\mathrm{MgCO} 3 \\
\text { Inerts }\end{array}$ & $\begin{array}{r}56.08 \\
100.09 \\
72.14 \\
136.14 \\
40.31 \\
84.32\end{array}$ & & & & & & & & \\
\hline \multicolumn{10}{|l|}{ TOTAL SORBENT } \\
\hline TOTAL FLOW. Lb/Hr & & & 157.995 & & 15.448 & & 176 & & 446 \\
\hline $\begin{array}{l}\text { HEATING VALUE: } \\
\text { Gas LHV, Btu/SCF } \\
\text { Gaseous Fuel LHV. }\end{array}$ & $8 \mathrm{tu} / \mathrm{hr}$ & & & & $\begin{array}{r}129 \\
30.9\end{array}$ & & $\begin{array}{l}136 \\
0.4\end{array}$ & & $\begin{array}{l}136 \\
0.9\end{array}$ \\
\hline $\begin{array}{l}\text { TEMPERATURE, } F \\
\text { PRESSURE, PSIA }\end{array}$ & & & $\begin{array}{r}240 \\
1.075\end{array}$ & & 3. 350 & & $\begin{array}{l}230 \\
310\end{array}$ & & $\begin{array}{l}230 \\
263\end{array}$ \\
\hline
\end{tabular}

Note: 1. Streams 43 and 44 are time averaged flow rates. 
HEAT AHD MATERIAL BALANCE - BASE CASE

UNDRIED SUFCO COAL WITH TRAKSPORT DESULFURIZER

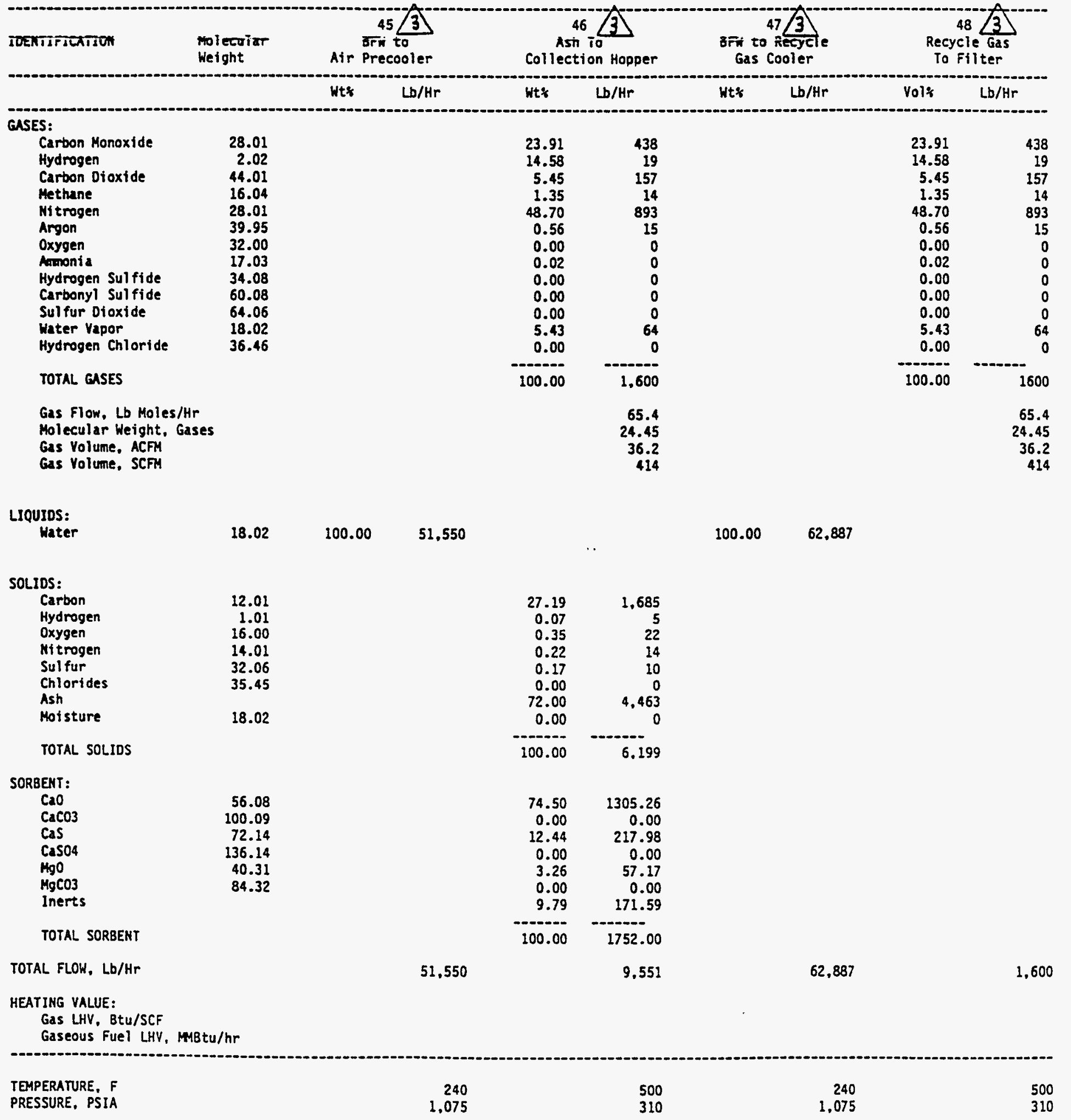


HEAT NMO MATERIAL BALANCE - BASE CASE

UNDRIED SUFCO COAL WITH TRANSPORT DESULFURIZER

\begin{tabular}{|c|c|c|c|c|c|c|c|c|c|}
\hline \multirow[t]{2}{*}{ IDENTIFICATION } & \multirow[t]{2}{*}{$\begin{array}{l}\text { Motecular } \\
\text { Weight }\end{array}$} & \multicolumn{2}{|c|}{$\begin{array}{l}\text { Air To } \\
\text { Sulfator }\end{array}$} & \multicolumn{2}{|c|}{$\begin{array}{l}\text { Steam From Product } \\
\text { Gas Trim Cooler }\end{array}$} & \multicolumn{2}{|c|}{$\begin{array}{l}\text { Net Steam From solfacor } \\
\text { Steam Orum }\end{array}$} & \multicolumn{2}{|c|}{$\begin{array}{l}\text { Stean From Product } \\
\text { Gas Cooler }\end{array}$} \\
\hline & & Yolf & $\mathrm{Lb} / \mathrm{Hr}$ & Vol:s & $\mathrm{Lb} / \mathrm{Hr}$ & Volt: & $\mathrm{Lb} / \mathrm{Hr}$ & Volt: & $\mathrm{Lb} / \mathrm{Hr}$ \\
\hline $\begin{array}{l}\text { SES: } \\
\text { Carbon Monoxide } \\
\text { Hydrogen } \\
\text { Carbon Dioxide } \\
\text { Methane } \\
\text { Mitrogen } \\
\text { Argon } \\
\text { Oxygen } \\
\text { Ammonia } \\
\text { Hydrogen Sulfide } \\
\text { Carbonyl Sulfide } \\
\text { Sulfur Dioxide } \\
\text { Water Vapor } \\
\text { Hydrogen Chloride }\end{array}$ & $\begin{array}{r}28.01 \\
2.02 \\
44.01 \\
16.04 \\
28.01 \\
39.95 \\
32.00 \\
17.03 \\
34.08 \\
60.08 \\
64.06 \\
18.02 \\
36.46\end{array}$ & $\begin{array}{r}0.00 \\
0.00 \\
0.00 \\
0.00 \\
78.00 \\
0.90 \\
20.82 \\
0.00 \\
0.00 \\
0.00 \\
0.00 \\
0.29 \\
0.00\end{array}$ & $\begin{array}{r}0 \\
0 \\
0 \\
0 \\
20,677 \\
339 \\
6.305 \\
0 \\
0 \\
0 \\
0 \\
49 \\
0\end{array}$ & 100.00 & 34,182 & 100.00 & 42.704 & 100.00 & 59.297 \\
\hline TOTAL GASES & & 100.00 & 27,370 & 100.00 & 34.182 & 100.00 & 42.704 & 100.00 & 59,297 \\
\hline $\begin{array}{l}\text { Gas Flow. Lb Moles } \\
\text { Molecular Weight, } \\
\text { Gas Volume, ACFM } \\
\text { Gas Volume, SCFM }\end{array}$ & $\begin{array}{l}r \\
\text { ses }\end{array}$ & & $\begin{array}{r}946.4 \\
28.92 \\
4486.3 \\
5.983\end{array}$ & & $\begin{array}{r}1.897 .4 \\
18.02 \\
239.8 \\
11.998\end{array}$ & & $\begin{array}{r}2.370 .5 \\
18.02 \\
299.6 \\
14.989\end{array}$ & & $\begin{array}{r}3.291 .5 \\
18.02 \\
416.0 \\
20,813\end{array}$ \\
\hline
\end{tabular}

\section{LIQUIDS:}

Water

18.02

SOLIOS:

$\begin{array}{lr}\text { Carbon } & 12.01 \\ \text { Hydrogen } & 1.01 \\ \text { Oxygen } & 16.00 \\ \text { Nitrogen } & 14.01 \\ \text { Sulfur } & 32.06 \\ \text { Chlorides } & 35.45 \\ \text { Ash } & \\ \text { Moisture } & 18.02\end{array}$

TOTAL SOLIDS

SORBENT:

$\mathrm{CaO}$

$\mathrm{CaCO}$

Cas

$\mathrm{CaSO} 4$

$\mathrm{MgO}$

$\mathrm{MgCO}$

Inerts

TOTAL SORBENT
56.08

100.09

72.14

136.14

40.31

84.32

TOTAL FLOW. Lb/Hr

HEATING VALUE:

Gas LHV, Btu/SCF

Gaseous fuel LHV, Btu/hr 
HEAT AND MATERIAL BALANCE - BASE CASE

UNDRIED SUFCO COAL WITH TRANSPORT DESULFURIZER

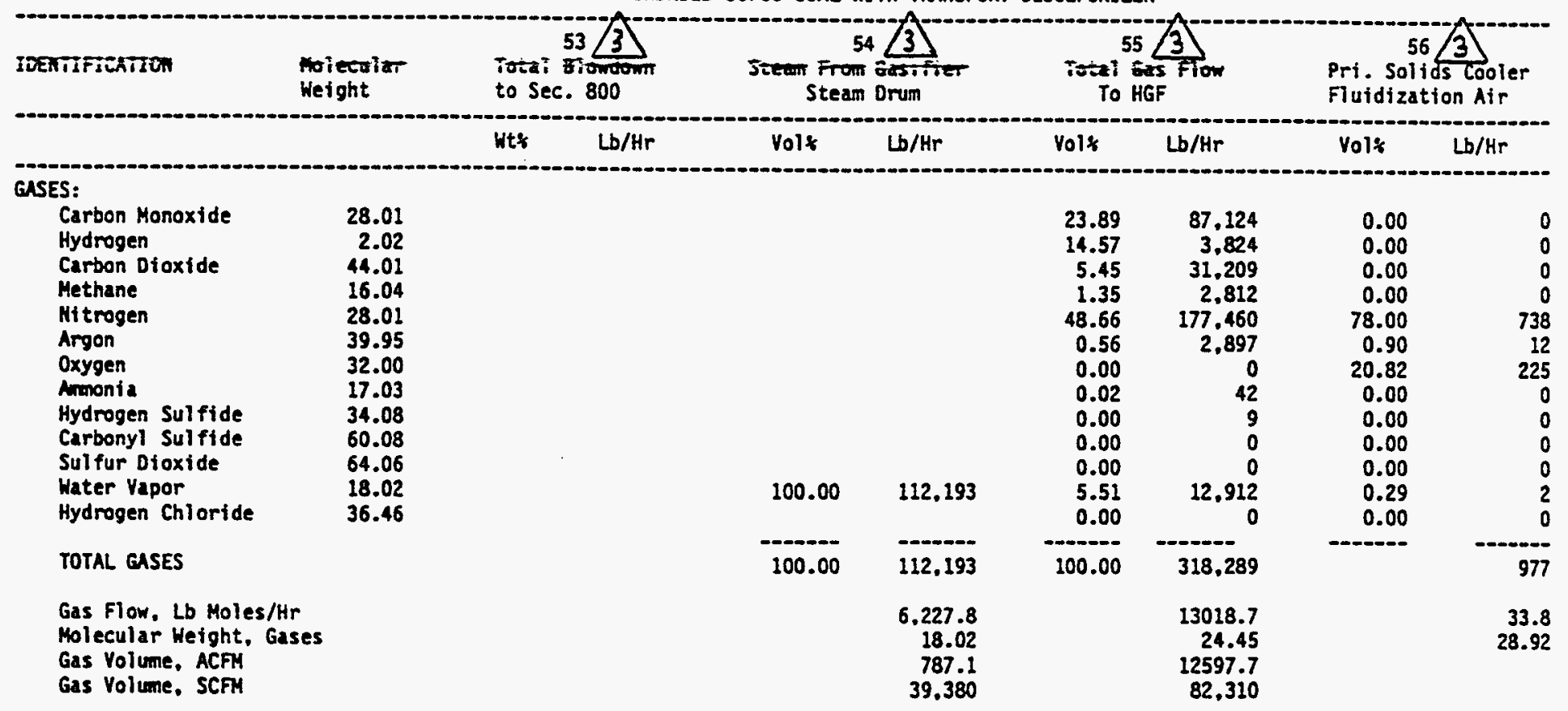

LIQUIDS:
Water
18.02
100.00
3,098

SOLIDS:

$\begin{array}{lr}\text { Carbon } & 12.01 \\ \text { Hydrogen } & 1.01 \\ \text { Oxygen } & 16.00 \\ \text { Nitrogen } & 14.01 \\ \text { Sulfur } & 32.06 \\ \text { Chlorides } & 35.45 \\ \text { Ash } & \\ \text { Moisture } & 18.02\end{array}$

12.01

14.01

35.45

Moisture

18.02

TOTAL SOLIOS

SORBENT:

$\begin{array}{lr}\mathrm{CaO} & 56.08 \\ \mathrm{CaCO} & 100.09 \\ \mathrm{CaS} & 72.14 \\ \mathrm{CaSO} & 136.14 \\ \mathrm{MgO} & 40.31 \\ \mathrm{MgCO3} & 84.32 \\ \text { lnerts } & \end{array}$

TOTAL SORBENT

TOTAL FLOW, Lb/Hr

Wty

\begin{tabular}{rr}
54.20 & 2.656 \\
0.33 & 16 \\
0.70 & 34 \\
0.41 & 20 \\
0.36 & 18 \\
0.00 & 0 \\
44.00 & 2.156 \\
0.00 & 0 \\
\hdashline 100.00 & 4.900
\end{tabular}

\begin{tabular}{rr}
74.50 & 539 \\
0.00 & 0 \\
12.44 & 90 \\
0.00 & 0 \\
3.26 & 24 \\
0.00 & 0 \\
9.79 & 71 \\
\hline 100.00 & 724
\end{tabular}

323.913

heATING VALUE:

Gas LHV, Btu/SCF

Gaseous Fuel LHV, MBtu/hr

129

637.0

TEMPERATURE, $F$

PRESSURE, PSIA 
HEAT AND MATERIAL BALANCE - BASE CASE

UNORIED SUFCO COAL WITH TRAHSPORT DESULFURIZER

\begin{tabular}{lr} 
IDENITFICATION & $\begin{array}{l}\text { Moiecuia } \\
\text { Weight }\end{array}$ \\
\hline GASES: & 28.0 \\
Carbon Monoxide & 2.02 \\
Hydrogen & 44.0 \\
Carbon Dioxide & 16.04 \\
Methane & 28.0 \\
Mitrogen & 39.95 \\
Argon & 32.00 \\
Oxygen & 17.03 \\
Aumonia & 34.08 \\
Hydrogen Sulfide & 60.08 \\
Carbonyl Sulfide & 64.06 \\
Sulfur Dioxide & 18.02 \\
Water Vapor & 36.4 \\
Hydrogen Chloride &
\end{tabular}

$57 / 3$

Tutai क्ति To Sulfator HRSG
Wty $\mathrm{Lb} / \mathrm{Hr}$
$58 / 3$

Totai jद्या Export to Sec. 800
9

Ait tis Fines Combustor

$\mathrm{Volt} \quad \mathrm{Lb} / \mathrm{Hr}$

$\mathrm{Lb} / \mathrm{Hr}$

$\mathrm{Lb} / \mathrm{Hr}$

\subsection{0}

0.00

0.00

0.00

78.00

0.90

20.82

32.00

17.03

60.08

64.06

36.46

TOTAL GASES

Gas Flow, Lb Moles/Hr

Molecular Weight. Gases

Gas Volune, ACFM

Gas Volune, SCFM

\section{LIQUIOS:}

Water

SOLIOS:

$\begin{array}{lr}\text { Carbon } & 12.01 \\ \text { Hydrogen } & 1.01 \\ \text { Oxygen } & 16.00 \\ \text { Nitrogen } & 14.01 \\ \text { Sulfur } & 32.06 \\ \text { Chlorides } & 35.45 \\ \text { Ash } & \\ \text { Moisture } & 18.02\end{array}$

TOTAL SOLIOS

SORBENT:

$\begin{array}{lr}\mathrm{CaO} & 56.08 \\ \mathrm{CaCO} & 100.09 \\ \mathrm{CaS} & 72.14 \\ \mathrm{CaSO} & 136.14 \\ \mathrm{MO} & 40.31 \\ \mathrm{MgCO} & 84.32\end{array}$

Inerts

TOTAL SORBENT

TOTAL FLOW, Lb/Hr

18.02

100.00

43.558

18.02

$1,294.2$

54,369

0.00

0.00

$154.897 \quad 0.00$

0.29

0.00

100.00

154,897

100.00

8.598 .2

.00
43,558

154,897

0

0

0
0
0

67.957

1.115

20,722

0

0

160

89.954

$3,110.3$

28.92

19268.7

19,665

$60 / 3$

Fines Combustor Effluents To HRSG

Vols $\mathrm{Lb} / \mathrm{Hr}$

\begin{tabular}{rr}
0.00 & \\
0.00 & 0 \\
9.65 & 0 \\
0.00 & 18,033 \\
77.23 & 0 \\
0.89 & 91.879 \\
10.33 & 1.507 \\
0.00 & 14.044 \\
0.00 & 1 \\
0.00 & 0 \\
0.01 & 0 \\
1.88 & 37 \\
0.00 & 1.438 \\
\hline 100.00 & 0 \\
& 126.939 \\
& 4.246 .7 \\
& 29.89 \\
& 117542.6 \\
& 26.849
\end{tabular}

hEATING VALUE:

Gas LHV. Btu/SCF

Gaseous Fuel LHV, MBtu/hr

TEMPERATURE, $F$

PRESSURE, PSIA

240

240
1,075

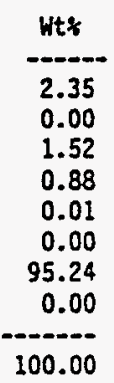

74.50

0.00

12.44

0.00

3.26

0.00

9.79

100.00

89,954
2,156

2.264

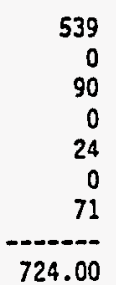

129,926
600

1,020
150

18
1.800
15 
HEAT NND MATERIAL BALANCE - BASE CASE UNDRIED SUFCO COAL WITH TRAHSPORT DESULFURIZER

\begin{tabular}{|c|c|c|c|c|c|c|c|}
\hline \multirow[t]{2}{*}{ IOENTIFICATIOI } & \multirow[t]{2}{*}{$\begin{array}{l}\text { Moiecuiar } \\
\text { Weight }\end{array}$} & \multicolumn{2}{|c|}{$\begin{array}{c}\text { Cooied Extraction } \\
\text { Air To C201 }\end{array}$} & \multicolumn{2}{|c|}{$\begin{array}{l}\text { BFW/Steam rrom } \\
\text { E607 To S6401 }\end{array}$} & \multicolumn{2}{|c|}{$\begin{array}{c}\text { Total Desuifumizer } \\
\text { Aeration Gas }\end{array}$} \\
\hline & & Volt & $\mathrm{Lb} / \mathrm{Hr}$ & Volt & $\mathrm{Lb} / \mathrm{Hr}$ & Vol: & $\mathrm{Lb} / \mathrm{Hr}$ \\
\hline $\begin{array}{l}\text { GASES: } \\
\text { Carbon Monoxide } \\
\text { Hydrogen } \\
\text { Carbon Dioxide } \\
\text { Methane } \\
\text { Nitrogen } \\
\text { Argon } \\
\text { Oxygen } \\
\text { Annonia } \\
\text { Hydrogen Sulfide } \\
\text { Carbonyl Sulfide } \\
\text { Sulfur Dioxide } \\
\text { Water Vapor } \\
\text { Hydrogen Chloride }\end{array}$ & $\begin{array}{r}28.01 \\
2.02 \\
44.01 \\
16.04 \\
28.01 \\
39.95 \\
32.00 \\
17.03 \\
34.08 \\
60.08 \\
64.06 \\
18.02 \\
36.46\end{array}$ & $\begin{array}{r}0.00 \\
0.00 \\
0.00 \\
0.00 \\
78.00 \\
0.90 \\
20.82 \\
0.00 \\
0.00 \\
0.00 \\
0.00 \\
0.29 \\
0.00\end{array}$ & $\begin{array}{r}0 \\
0 \\
0 \\
0 \\
263,304 \\
2.678 \\
49.797 \\
0 \\
0 \\
0 \\
0 \\
385 \\
0\end{array}$ & 100.00 & 196 & $\begin{array}{r}23.91 \\
14.58 \\
5.45 \\
1.35 \\
48.70 \\
0.56 \\
0.00 \\
0.02 \\
0.00 \\
0.00 \\
0.00 \\
5.43 \\
0.00\end{array}$ & $\begin{array}{r}3.600 \\
158 \\
1,289 \\
116 \\
7.332 \\
120 \\
0 \\
2 \\
0 \\
0 \\
0 \\
526 \\
0\end{array}$ \\
\hline TOTAL GASES & & 100.00 & 216.164 & 100.00 & 196 & 100 & 13,144 \\
\hline \multicolumn{2}{|c|}{$\begin{array}{l}\text { Gas Flow, Lb Moles/Hr } \\
\text { Molecular Weight, Gases } \\
\text { Gas Volume, ACFM } \\
\text { Gas Volume. SCFM }\end{array}$} & & $\begin{array}{r}7.474 \\
28.92 \\
4912.8 \\
47.255\end{array}$ & & $\begin{array}{r}11 \\
18.02 \\
1.4 \\
69\end{array}$ & ' & $\begin{array}{r}538 \\
24.45 \\
232.3 \\
3.398\end{array}$ \\
\hline
\end{tabular}

LIQUIOS:

Water

SOLIDS:

$\begin{array}{lr}\text { Carbon } & 12.01 \\ \text { Hydrogen } & 1.01 \\ \text { Oxygen } & 16.00 \\ \text { Nitrogen } & 14.01 \\ \text { Sulfur } & 32.06 \\ \text { Chlorides } & 35.45 \\ \text { Ash } & \\ \text { Moisture } & 18.02\end{array}$

TOTAL SOLIDS

SORBENT:

$\begin{array}{lr}\mathrm{CaO} & 56.08 \\ \mathrm{CaCO} & 100.09 \\ \mathrm{CaS} & 72.14 \\ \mathrm{CaSO} & 136.14 \\ \mathrm{MgO} & 40.31 \\ \mathrm{MgCO} & 84.32\end{array}$

Inerts

TOTAL SORBENT

TOTAL FLOW, Lb/Hr

HEATING VALUE:

Gas LHY, BtU/SCF

Gaseous Fuel LHV, MBtu/hr
18.02

2.01

14.01

18.02

47.255
Sulfator Fines From Bh Filter 
hEAT AND MATERIAL BALANCE - BASE CASE

UNDRIED SUFCO COAL WITH TRANSPORT DESULFURIZER

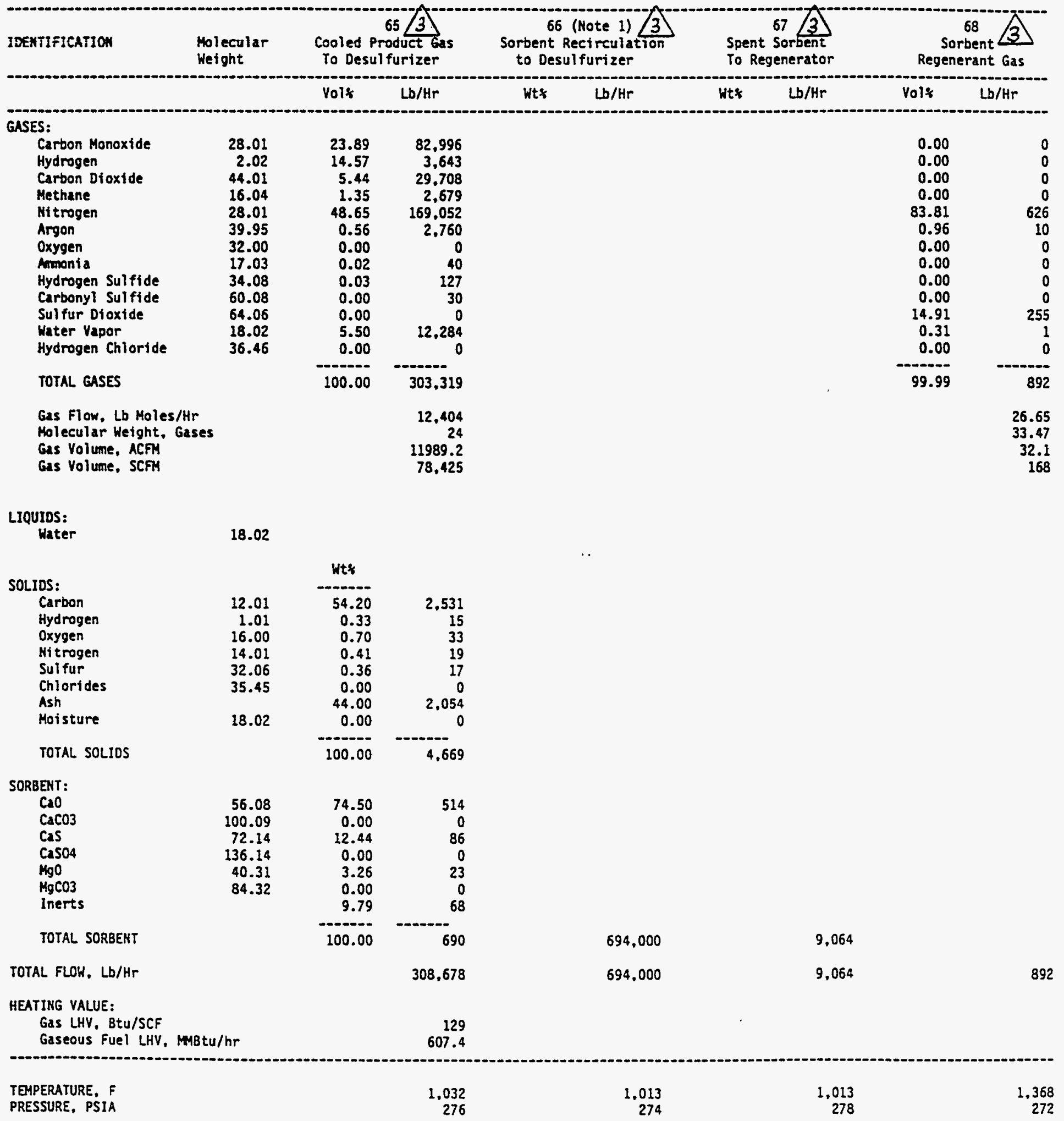

Note 1: Sorbent referred to in streams 66,67 , and 69 is the external desulfurizer sorbent. 
HEAT AND MATERIAL BALANCE - BASE CASE UNDRIED SUFCO COAL WITH TRANSPORT DESULFURIZER

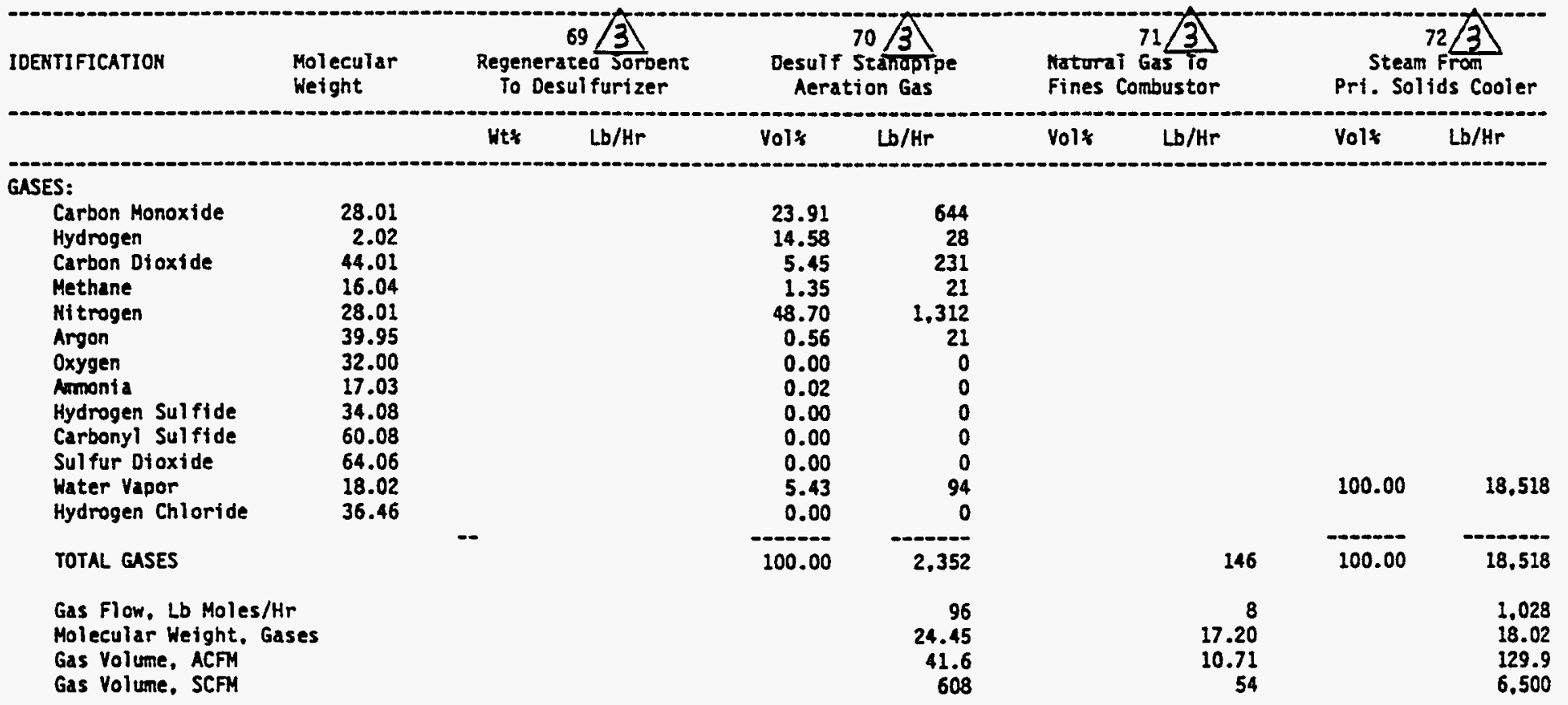

LIQUIDS:

Water $\quad 18.02$

SOLIDS:

Carbon 12.01

Hydrogen $\quad 1.01$

Oxygen $\quad 16.00$

Nitrogen $\quad 14.01$

Sulfur $\quad 32.06$

Chlorides $\quad 35.45$

18.02

TOTAL SOLIOS

SORBENT:

$\begin{array}{lr}\mathrm{CaO} & 56.08 \\ \mathrm{CaCO} & 100.09 \\ \mathrm{CaS} & 72.14 \\ \mathrm{CaSO} 4 & 136.14 \\ \mathrm{MgO} & 40.31 \\ \mathrm{MgCO} & 84.32\end{array}$

Inerts

TOTAL SORBENT

9,000

TOTAL FLOW, Lb/Hr

9,000

2,352

HEATING VALUE:

Gas LHV, Btu/SCF

Gaseous Fuel LHV, $\mathrm{Mtu} / \mathrm{hr}$

129

4.7

3.0 
HEAT AND MATERIAL BALAHCE - BASE CASE

UNDRIED SUFCO COAL WITH TRAHSPORT DESULFURIZER

\begin{tabular}{|c|c|c|c|c|c|}
\hline \multirow[t]{2}{*}{ JOENTIFLRTSO } & \multirow[t]{2}{*}{$\begin{array}{l}\text { Moiectiat } \\
\text { Weight }\end{array}$} & \multicolumn{2}{|c|}{$\begin{array}{l}\text { Aeration Rec. Gas } \\
\text { to HGF Bottom Cone }\end{array}$} & \multicolumn{2}{|c|}{$\begin{array}{c}74 / 3) \\
\text { Eessiforizet j-ies } \\
\text { Aeration Gas }\end{array}$} \\
\hline & & Volf & $\mathrm{Lb} / \mathrm{Hr}$ & Volt & $\mathrm{Lb} / \mathrm{Hr}$ \\
\hline $\begin{array}{l}\text { GASES: } \\
\text { Carbon Monoxide } \\
\text { Hydrogen } \\
\text { Carbon Dioxide } \\
\text { Methane } \\
\text { Mitrogen } \\
\text { Argon } \\
\text { Oxygen } \\
\text { Ammonia } \\
\text { Hydrogen Sulfide } \\
\text { Carbonyl Sulfide } \\
\text { Sulfur Dioxide } \\
\text { Water Vapor } \\
\text { Hydrogen Chloride }\end{array}$ & $\begin{array}{r}28.01 \\
2.02 \\
44.01 \\
16.04 \\
28.01 \\
39.95 \\
32.00 \\
17.03 \\
34.08 \\
60.08 \\
64.06 \\
18.02 \\
36.46\end{array}$ & $\begin{array}{r}23.91 \\
14.58 \\
5.45 \\
1.35 \\
48.70 \\
0.56 \\
0.00 \\
0.02 \\
0.00 \\
0.00 \\
0.00 \\
5.43 \\
0.00\end{array}$ & $\begin{array}{r}27 \\
1 \\
10 \\
1 \\
56 \\
1 \\
0 \\
0 \\
0 \\
0 \\
0 \\
4 \\
0\end{array}$ & $\begin{array}{r}23.91 \\
14.58 \\
5.45 \\
1.35 \\
48.70 \\
0.56 \\
0.00 \\
0.02 \\
0.00 \\
0.00 \\
0.00 \\
5.43 \\
0.00\end{array}$ & $\begin{array}{r}1.833 \\
80 \\
657 \\
59 \\
3,733 \\
61 \\
0 \\
1 \\
0 \\
0 \\
0 \\
268 \\
0\end{array}$ \\
\hline TOTAL GASES & & 100 & 100 & 100.00 & 6.692 \\
\hline \multicolumn{2}{|c|}{$\begin{array}{l}\text { Gas Flow, Lb Moles/Hr } \\
\text { Molecular Weight, Gases } \\
\text { Gas Volone, ACFM } \\
\text { Gas Volune, SCFM }\end{array}$} & & $\begin{array}{r}4.09 \\
24.45 \\
1.77 \\
25.85\end{array}$ & & $\begin{array}{r}274 \\
24.45 \\
118.3 \\
1.730\end{array}$ \\
\hline
\end{tabular}

LIQUIDS:

Water

18.02

SOLIDS:

$\begin{array}{lr}\text { Carbon } & 12.01 \\ \text { Hydrogen } & 1.01 \\ \text { Oxygen } & 16.00 \\ \text { Nitrogen } & 14.01 \\ \text { Sulfur } & 32.06 \\ \text { Chlorides } & 35.45 \\ \text { Ash } & \\ \text { Moisture } & 18.02\end{array}$

TOTAL SOLIOS

SORBENT:

$\begin{array}{lr}\mathrm{CaO} & 56.08 \\ \mathrm{CaCO} & 100.09 \\ \mathrm{CaS} & 72.14 \\ \mathrm{CaSO} & 136.14 \\ \mathrm{MgO} & 40.31 \\ \mathrm{MgCO} & 84.32\end{array}$

Inerts

TOTAL SORBENT

TOTAL FLOW, Lb/Hr

100

129

0.2

Gaseous Fuel LHV, MBtu/hr

TEMPERATURE, $F$

PRESSURE, PSIA
6,692

129

13.4 